\title{
Wounded heroes: Vulnerability as a virtue in ancient Greek literature and philosophy
}

\author{
Author: Marina McCoy
}

Persistent link: http://hdl.handle.net/2345/bc-ir:103502

This work is posted on eScholarship@BC, Boston College University Libraries.

New York: Oxford University Press, 2013

This is an open access version of the publication distributed under the terms of the Creative Commons Attribution-NonCommercial-NoDerivs license (http:// creativecommons.org/licenses/by-nc-nd/3.0/), which permits non-commercial reproduction and distribution of the work, in any medium, provided the original work is not altered or transformed in any way, and that the work is properly cited. 


\section{WOUNDED HEROES}

This is an open access version of the publication distributed under the terms of the Creative Commons AttributionNonCommercial-NoDerivs licence (http://creativecommons.org/licenses/by-nc-nd/3.0/), which permits non-commercial reproduction and distribution of the work, in any medium, provided the original work is not altered or transformed in any way, and that the work is properly cited. For commercial re-use, please contact academic.permissions@oup.com 
This is an open access version of the publication distributed under the terms of the Creative Commons AttributionNonCommercial-NoDerivs licence (http://creativecommons.org/licenses/by-nc-nd/3.0/), which permits non-commercial reproduction and distribution of the work, in any medium, provided the original work is not altered or transformed in any way, and that the work is properly cited. For commercial re-use, please contact academic.permissions@oup.com 


\title{
Wounded Heroes
}

\section{Vulnerability as a Virtue in Ancient Greek \\ Literature and Philosophy}

\author{
MARINA BERZINS MCCOY
}

\section{OXFORD}

UNIVERSITY PRESS

This is an open access version of the publication distributed under the terms of the Creative Commons AttributionNonCommercial-NoDerivs licence (http://creativecommons.org/licenses/by-nc-nd/3.0/), which permits non-commercial reproduction and distribution of the work, in any medium, provided the original work is not altered or transformed in any way, and that the work is properly cited. For commercial re-use, please contact academic.permissions@oup.com 


\title{
OXFORD \\ UNIVERSITY PRESS
}

Great Clarendon Street, Oxford, OX2 6DP, United Kingdom

Oxford University Press is a department of the University of Oxford. It furthers the University's objective of excellence in research, scholarship, and education by publishing worldwide. Oxford is a registered trade mark of

Oxford University Press in the UK and in certain other countries

(C) Marina Berzins McCoy 2013

The moral rights of the author have been asserted

First Edition published in 2013

Impression: 1

All rights reserved. No part of this publication may be reproduced, stored in a retrieval system, or transmitted, in any form or by any means, without the prior permission in writing of Oxford University Press, or as expressly permitted by law, by licence or under terms agreed with the appropriate reprographics rights organization. Enquiries concerning reproduction outside the scope of the above should be sent to the Rights Department, Oxford University Press, at the address above

You must not circulate this work in any other form and you must impose this same condition on any acquirer

Published in the United States of America by Oxford University Press 198 Madison Avenue, New York, NY 10016, United States of America

\author{
British Library Cataloguing in Publication Data \\ Data available \\ Library of Congress Control Number: 2013940862 \\ ISBN 978-0-19-967278-3 \\ Printed and bound by \\ CPI Group (UK) Ltd, Croydon, CR0 4YY
}

Links to third party websites are provided by Oxford in good faith and for information only. Oxford disclaims any responsibility for the materials contained in any third party website referenced in this work.

This is an open access version of the publication distributed under the terms of the Creative Commons AttributionNonCommercial-NoDerivs licence (http://creativecommons.org/licenses/by-nc-nd/3.0/), which permits non-commercial reproduction and distribution of the work, in any medium, provided the original work is not altered or transformed in any way, and that the work is properly cited. For commercial re-use, please contact academic.permissions@oup.com 


\section{Dedicated to \\ John, Katherine, and James}

This is an open access version of the publication distributed under the terms of the Creative Commons AttributionNonCommercial-NoDerivs licence (http://creativecommons.org/licenses/by-nc-nd/3.0/), which permits non-commercial reproduction and distribution of the work, in any medium, provided the original work is not altered or transformed in any way, and that the work is properly cited. For commercial re-use, please contact academic.permissions@oup.com 
This is an open access version of the publication distributed under the terms of the Creative Commons AttributionNonCommercial-NoDerivs licence (http://creativecommons.org/licenses/by-nc-nd/3.0/), which permits non-commercial reproduction and distribution of the work, in any medium, provided the original work is not altered or transformed in any way, and that the work is properly cited. For commercial re-use, please contact academic.permissions@oup.com 


\section{Preface}

Vulnerability is not often associated with virtue. Yet, to be vulnerable is central to human experience. Etymologically, 'being vulnerable' means capable of being wounded (from its Latin root, vulnus or wound). Thus vulnerability, as the capacity to be hurt, is distinct from the state of actually being harmed or suffering pain. Instead of communicating the actual experience of pain or harm, the term communicates the possibility of such experience, and self-awareness of its possibility. One can know of one's own capacity to be wounded directly, by experiencing suffering, but may also know it in significant ways in the anticipation of harm, in its likelihood. To this extent, vulnerability concerns not only the present moment, but also the future. Vulnerability is a part of the human condition that is concerned with living as temporal creatures who undergo change and transformations of various sorts and who live with an awareness of the likelihood of change. At times these changes are joyful or satisfying, at times painful or needful. A self-conscious and aware person understands the meaning of his or her life in terms of a larger temporal whole, of which vulnerability forms one part.

Narrative is a central mode of expression through which human beings find and create meaning about the experiences and patterns in their lives. Such patterns are sometimes discovered or felt to be 'found' at the phenomenological level, but often only after the fact. Current incidents or experiences, whether positive or negative, often take on a different kind of meaning in human retelling of the events later; what was confusing or chaotic at the moment may later display a kind of sense or meaning. At the experiential level, this meaning is often found by making connections between events, persons, and larger purposes that were not before apparent. While the meaning of an immediate experience of happiness seems not to require explanation (in its pleasure and seeming 'fit' with our expectations of happiness), suffering seems to demand explanation. When people experience pain of their own, or witness it in others-especially in extreme cases-there is an experiential demand to understand its meaning, even when such meaning seems to be unavailable or difficult to discern. Such meaning is often developed through narratives, 
stories told about painful events, whether historical or mediated fictions. The historical existence of real suffering makes significant its performance in tragedy or other forms of $\mu v^{\prime} \theta o s$. But $\mu v^{\prime} \theta$ os also reflects back on how we come to understand real human experience. Indeed, such experiences are reflected on by whole communities, and not only individuals, for the suffering of others, or its possibility, is also central to human experience. Not only my own, but also others' suffering, is constitutive of my own vulnerability.

The contention of this book is that Greek epic, tragedy, and philosophy have important insights to offer about the nature of human vulnerability and how human beings might better come to terms with their own vulnerability. While studies of Greek paradigms of heroism and virtue often focus on strength of character, prowess in war, or the achievement of honour for oneself or one's $\pi$ ó $\lambda \iota s$, there is another side to Greek thought that extols the recognition and proper acceptance of vulnerability. A number of Greek authors address the question of the political value of vulnerability. Homer takes on the dark side of war and does not shy away from descriptions of human suffering along with glory. Sophocles creates a supreme tension between the expectation of order and control, and the reality of convoluted and unexpected human experience. Philosophers seek to not only offer moral and political solutions to suffering, but also set out the limits of such solutions and even extol the virtues of acknowledging and accommodating human limit.

The range of works that might be chosen to display Greek engagement with vulnerability is nearly inexhaustible. Thus, my aim here has not been to develop anything like a comprehensive theory of 'Greek culture'. Neither is the development of a 'theory of tragedy' the primary aim-indeed, two works of Sophocles would hardly suffice to develop such a theory. Instead, the larger purpose of the book is to analyse and interpret several important Greek works of epic, tragedy, and philosophy in order better to develop a philosophical understanding of vulnerability and its role in the life of the larger community. I have chosen literary and philosophical works in which the imagery of wounding is prominent, or in which the question of vulnerability's relationship to ethical-political life is confronted directly. Physical wounds in these works are often accompanied by deeper questions about the meaning of suffering, mortality, or other forms of human frailty. The focus on works in which physical wounds are prominent features of the story thus serves as a trope for delving 
more deeply into psychological, ethical, and interpersonal vulnerabilities and their place in the community.

The overarching thesis concerns itself with the central philosophical questions: (1) Why is awareness and acceptance of human vulnerability important to the thriving of both individuals and communities? (2) How does narrative allow human beings better to become aware of and respond to their own vulnerability? I argue that awareness of one's own and others' capacity to be wounded, and the proper response to it, are a central part of virtue for successful communities. Not only individuals, but also political communities, must come to terms with and respond appropriately to the vulnerability that exists within. Indeed, vulnerability strengthens interpersonal bonds within a community, and is closely intertwined with a number of different facets of ethical life. I thus suggest that rather than treating vulnerability as something to be avoided, vulnerability is a necessary component of living a rich and authentic human life in community.

A good deal of scholarship in philosophy focuses on the virtues, that is, human excellence. This attention to the virtues makes good sense, for certainly philosophers and even epic writers and tragedians seek to articulate the ways in which human beings can successfully pursue lives of happiness and ethical living. Careful attention to the virtues that allow the best aspects of human beings to emerge-or that assist us in combatting the worst-naturally focuses on human strengths and political resourcefulness. Nonetheless, the reality of human life often bumps up against the idealism of philosophy. The meaning of acute human suffering is difficult to discern. Moreover, in the course of everyday encounters with others, the question as to the proper responsiveness to others' vulnerability arises. I offer this work on vulnerability not as an objection to the necessity of cultivating individual and political excellence, but rather as complementary. To be aware of and responsive to the vulnerabilities of oneself and others is just as important as our care for human excellence and strength. Indeed, the success of the political community already depends upon its own recognition and appropriation of vulnerability in its midst. The appropriate response to vulnerability is thus a key part of virtue.

My work builds on the scholarship of a few other key figures who have taken on the topic of human weakness. Martha Nussbaum's book, The Fragility of Goodness, remains a formative work on moral luck in Greek tragedy and philosophy. Her insights into the role of 
chance and contingency in ethical living are valuable. However, I take issue with her contention that Plato argues for a life of self-sufficiency and freedom from contingency. As I will argue in the middle chapters of this book, Plato displays considerable sensitivity to human vulnerability. Socratic questioning seems even to depend on a care for human weakness along with love of the good. MacIntyre's Dependent Rational Animals similarly argues that vulnerability and even disability are normal features of ordinary life. His attention to the links between human persons and animals, and especially our embodied dependencies, relies to a large extent on a thoughtful analysis of Aristotelian epistemology, as well as contemporary biology. His work on Aristotle's theory of perception and the imagination especially plays an important role in the final chapter. Numerous other commentators have focused on the meaning of suffering in Greek tragedy and Homeric epic, both at the textual and performative levels. Still, suffering and vulnerability are not quite identical, and I hope that my own insights here build upon those of my predecessors.

In Chapter 1, I examine the descriptions of wounding in Homer's Iliad for its insights into vulnerability and its meaning. Homer presents wounds and their signifying of mortality as central to the possibility of a meaningful, teleological narrative about human life. In contrast to the wounds suffered by the gods, human wounds increase the bonds of relationships within the community. While neither pain nor death are desirable in themselves, their anticipation and the narrative accounts offered in light of their existence contribute to political goods. Thus, the limitedness of human beings provides for the possibility of teleological meaning that the gods cannot possess. Achilles initially resists the vulnerability of both himself and the other Greeks, but is brought to face its reality through two key events: the death of Patroklos and the final encounter with Priam, in which Achilles agrees to return Hektor's body. In the Iliad, awareness of vulnerability to death, injury, and even the inevitable 'forward motion' of time provide for the possibility of a meaningful individual human narrative. Narrative also links the meaning of individual lives and deaths to a larger set of patterns and meanings within the Greek story. Achilles' meeting with Priam even allows Achilles to enter more deeply into the universality of human suffering and so to extend his community even beyond that of the Greeks.

Chapter 2 turns to Sophocles' Oedipus the King and Oedipus at Colonus. In the first play, vulnerability to ignorance constitutes a 
danger to the community, as Oedipus' self-assurance about his own righteousness contributes to his city's and family's downfall. Oedipus initially refuses to accommodate weakness and vulnerability to uncontrollable forces into his vision of human life, and his refusal has grave consequences for those whom he rules and those whom he loves. However, Theseus in Oedipus at Colonus suggests an alternative approach to vulnerability, as Theseus displays compassionate hospitality for the stranger. The figure of Oedipus as a $\xi^{\prime} \epsilon^{\prime} o s$ in Colonus reconciles the split between his identity as a polluted man and as a political protector. His incorporation and elevation to protector of Athens displays the Athenian ideal of the $\pi$ ó $\iota_{\iota s}$ as the dwelling of 'all together', in which receptivity to the outsider and even to weakness becomes constitutive of the city's good.

In Chapter 3, I examine Sophocles' Philoctetes and build further on the notion that the excluded and polluted one is central to the city's good. Here, Sophocles develops a picture of Philoctetes as one who is not only physically, but also emotionally, wounded. His presence at an 'in between' space on Lemnos, literally at the margins of society, further develops a picture of human vulnerability, especially the suffering born from social exclusion. The figure of Neoptolemus and his internal struggles also develops two political virtues in the play: first, pity as a political virtue and, second, the virtue of being able to accommodate unjust harm properly. Neoptolemus learns from Philoctetes both the importance of pity and a form of political citizenship that accommodates truthfulness and care for the weak, in place of mere political efficacy. Philoctetes learns the necessity of being able to return to his place in an imperfect Greek society that has not expressed regret for his prior abandonment. These two political virtues both concern a proper responsiveness and care for vulnerability-not only care for the weak, but also acceptance and care for one's own city in light of the imperfections of political structures.

Plato's dialogues include both a literary and philosophical dimension. While Plato is often interpreted as an author who advocates philosophy as a way to overcome vulnerability, I argue that the Gorgias and Symposium both display considerable sensitivity to vulnerability and its importance in human life. Chapter 4 focuses on the myth of judgement at the end of the Gorgias and its image of a wounded, unjust man. There Socrates uses a $\mu v^{\prime} \theta o s$ and, in particular, the language of wounding to communicate with Callicles, who has so far failed to be responsive to abstract argumentation. Just as the 
judges of the myth can judge well only because they are naked, as are the ones that they judge, Socrates emerges as one who is able to excel at questioning others because of his self-awareness of his vulnerability. Socrates not only is vulnerable to the judgement in the courtroom, but also displays an epistemic vulnerability that guides his questioning of others. I also argue that Ancient Greek medicine and its recognition of a healer's own limits have significant parallels to Socratic practice. Socrates is not only responsive to the 'wounds' of those whom he attends, but is also self-aware of his limitations as a practitioner. He thus displays a consciousness of the finite power of Socratic logos to transform an interlocutor. Plato emerges not as a perfectionistic thinker who desires to avoid tragedy and human frailty, but rather as a thinker who is aware and accepting of human limitation and vulnerability.

Next, I turn to Plato's Symposium. Chapter 5 examines the links between eros and vulnerability. Against those who read the Symposium's 'ladder of love' as a move away from loving the ordinary and imperfect, I advocate an understanding of philosophy that retains a care for the imperfect and ordinary. Diotima's speech describes eros, at its last stage before reaching the finality of eternal contemplation, as the place where human creativity takes place. Reproduction in not only a physical, but also an intellectual and creative, sense is part of the human response to our own need and lack, as we strive for but cannot yet reach the eternal. The fruitfulness of eros depends upon a lack and need in human beings, and their responsiveness to the neediness of one another, and not an other-worldly or perfectionistic orientation. Alcibiades' entrance into the party as a drunk, erotic, and frustrated young man who speaks of suffering from a Socraticallyinduced 'snakebite' also suggests a tragic dimension to eros. While Alcibiades displays a greater sensitivity to his own vulnerability than any other Socratic interlocutor in the dialogue, he fails to be able to move from such self-awareness into action that transforms his life accordingly. I suggest that Alcibiades is unwilling to take responsibility for his own limits and wounds, choosing instead to blame Socrates. Socrates, in contrast, remains aware of his own limit, responsible for it, and so takes his neediness and eros into his actions. He thus stands as a practitioner of not only good philosophy, but also political care for others.

The final two chapters analyse Aristotle's thoughts on vulnerability in the Ethics and Poetics. Chapter 6 carefully analyses Aristotle's 
discussion of the loss of a friendship of virtue in which one's friend has become bad. While Aristotle argues that a virtuous man will only love what is truly good-and so not a friend turned bad-his discussion of the loss of such a friend displays how friendship itself makes us vulnerable. While we need friends to practise the virtues and to reflect ourselves back to us, a friend is also valued in himself, as 'another self'. The loss of friendship entails a concomitant loss of an aspect of one's own self. Aristotle suggests that such friendships can be retained to some extent in memory, but even memory retains the pain suffered in loss, as well as the goods, of the friendship. Aristotle also posits the relative limits of not only friends, but also family, civic institutions, and laws in rehabilitating those who have fallen away from virtue. One way to understand those who lack virtue is in terms of their moral vulnerability. But no single form of familial, personal, or civic care is entirely sufficient to attend to such a state of soul. A wide range of forms of moral care and nurture are necessary for the sake of moving those who lack virtue toward its acquisition.

The last chapter turns to Aristotle's discussion of tragedy and narrative in the Poetics. I especially look at the public, performed aspect of tragedy and what meaning witnessing tragedy as a political community might have for the body politic. I suggest that one political function of tragedy is to enable a community to become more responsive to the vulnerable in their own midst. I then take up Aristotle's notion of $\kappa a ́ \theta \alpha \rho \sigma \iota s$ and argue for $\kappa a ́ \theta \alpha \rho \sigma \iota s$ as a form of 'rebalancing', not only of an individual soul, but also of the community at large. Tragedy can enlarge a community's vision of its own identity and the realities of its own citizens, including vulnerable citizens. Tragedy and other forms of narrative thus possess not only an aesthetic, but also a political and philosophical, function. 
This is an open access version of the publication distributed under the terms of the Creative Commons AttributionNonCommercial-NoDerivs licence (http://creativecommons.org/licenses/by-nc-nd/3.0/), which permits non-commercial reproduction and distribution of the work, in any medium, provided the original work is not altered or transformed in any way, and that the work is properly cited. For commercial re-use, please contact academic.permissions@oup.com 


\section{Acknowledgements}

I am grateful to the many people who have contributed to the formation of this book. While Plato wrote that all philosophy begins in wonder, decent philosophy only develops through conversation, and whatever strengths there are in the book are the product of many conversations, both professionally and personally. I especially appreciate the work of Sara Brill, Ryan Drake, Jill Gordon, Gary Gurtler SJ, Christopher Long, Arthur Madigan SJ, Paul McNellis SJ, Heidi Northwood, Ross Romero SJ, and William Wians, who read and commented on sections of the book as it was in progress. Jason Taylor deserves special thanks for his work in reading the manuscript in its entirety and offering valuable comments on matters of classical scholarship as it neared completion. Marjolein Oele's work on the relationship between Priam and Achilles inspired me to look more deeply into that aspect of the Iliad, and I am deeply indebted to her philosophical insights. Stephen Scully was helpful with pointing me to material on Homeric manuscripts, and both Richard Kearney and John Panteleimon Manoussakis provided useful comments on material on Oedipus. More informal conversations on these topics with Holly Moore, John Murray SJ, Adriel Trott, and Mary Troxell also helped me think through these ideas both academically and personally.

Presentations on material related to this book took place at Baylor University, Boston College, Nazareth College, St John's College (Annapolis), Utah Valley University's Honors Program, the Ancient Philosophy Society annual conference, and the Society for Ancient Greek Philosophy annual conference. Particularly helpful were commentators and/or hosts Brian Braman, William Harwood, Allen Hill, Shannon Mussett, Michael Shaw, John Tomarchio, and Anne Marie Schultz. Conversations with faculty and students at these presentations also helped better to develop the ideas.

This book began as the topic of a graduate seminar at Boston College, and I am grateful to each and every one of the students in that class who offered feedback on the lecture and fresh insights into the texts and questions raised in class. Special thanks go to Santiago Ramos and Anna Besch, who served as graduate research assistants 
and gave exceptionally helpful assistance. Reham Elnory also provided useful support. I would also like to thank my dean, David Quigley, for approving a sabbatical in which substantial portions of the book were written. Two anonymous reviewers from Oxford University Press provided detailed and most valuable comments on the manuscript; I would like to thank them for their careful attention and thoughtfulness in the process. Last, but certainly not least, my editor, Hilary O'Shea, was invaluable at every step of the process, as were Cathryn Steele, Taryn Das Neves, Kizzy Taylor-Richelieu, and all those involved in the manuscript production at OUP.

Thanks also to the permissions departments of Penguin and Yale. Translations of the Iliad are from The Iliad by Homer, translated by Robert Fagles, translation copyright 1990 by Robert Fagles, used by permission of Viking Penguin, a division of Penguin Group (USA) Inc. Translations of the Symposium are from The Symposium, translated by R. E. Allen, Yale University Press, 1991, used by permission of Yale University Press.

Last, but certainly not least, I would like to thank my friends and family for their warm support throughout the writing process. This book is dedicated to my husband and children, whose love sustains me always. 


\section{Contents}

1. Woundedness, Narrative, and Community in the Iliad 1

2. Oedipus and Theseus at the Crossroads 37

3. Pity as a Civic Virtue in Sophocles' Philoctetes 63

4. Wounding and Wisdom in Plato's Gorgias 89

5. Eros, Woundedness, and Creativity in Plato's Symposium 115

6. Friendship and Moral Failure in Aristotle's Ethics 141

7. Tragedy, Katharsis, and Community in Aristotle's Poetics 169

8. Conclusion 205

Bibliography 211

Index 223 
This is an open access version of the publication distributed under the terms of the Creative Commons AttributionNonCommercial-NoDerivs licence (http://creativecommons.org/licenses/by-nc-nd/3.0/), which permits non-commercial reproduction and distribution of the work, in any medium, provided the original work is not altered or transformed in any way, and that the work is properly cited. For commercial re-use, please contact academic.permissions@oup.com 


\section{1 \\ Woundedness, Narrative, and Community in the Iliad}

Traditionally, the Iliadic hero is a man of courage, strength, and selfcontrol who gains glory as a result of his individual actions. Both Achilles and Hektor are men who understand their participation and valour in battle as necessary for achieving $\kappa \lambda \epsilon o$ s (glory) in light of the inevitability of death. At the same time, Homer is concerned not only with the individual Greek man of virtue, but also with his relation to the larger community. This chapter argues that the Iliad presents vulnerability as central to the possibility of a strong socio-political bond, especially insofar as the acknowledgement of human mortality is necessary for the thriving of both individuals and communities. ${ }^{1}$ In particular, Homer's presentation of the wounds of warriors shows the centrality of vulnerability to the possibility of a teleological narrative of human existence, offering meaning in the face of mortality.

${ }^{1}$ While many commentators emphasize the role of virtue and honour in the Iliad, only a few have focused on the place of vulnerability and weakness. Among notable exceptions are Michael Lynn-George, 'Aspects of the Epic Vocabulary of Vulnerability', Colby Quarterly 29 (3) (1996), 197-221; Graham Zanker, The Heart of Achilles: Characterization and Personal Ethics in the Iliad (Ann Arbor: University of Michigan Press, 1996); Brooke Holmes, 'The Iliad's Economy of Pain', Transactions of the American Philological Association 137 (1) (Spring 2007); Arlene Saxonhouse, 'Thumos, Justice, and Moderation of Anger in the Story of Achilles', in Catherine Zuckert (ed.), Understanding the Political Spirit (New Haven: Yale University Press, 1988); and Simone Weil's 'The Iliad, or the Poem of Force', in S. Weil and R. Bespaloff (eds.), War and the Iliad (New York: New York Review Books, 2005), 3. See also K. LynnGeorge, 'Structures of Care in the Iliad', Classical Quarterly 46 (1) (1996), 1-26 for an in-depth discussion of the vocabulary of care and Louise Pratt, 'The Parental Ethos of the Iliad', Hesperia Supplements 41 (2007), 25-40. My own focus here on the contrast between divine and mortal wounds, temporality, narrative, and food adds new material to the picture of vulnerability in the Iliad that these authors have begun to develop. 
Achilles especially must come to terms with the 'forward motion' of human life, and his inability to remain in the past, as part of human experience. His virtue requires not only his willingness to die an honourable death for his fellow Greeks, but also his ability to accept the loss of Patroklos and to face the inevitable forward motion of human existence. This temporal character of experience is painful, but also allows for the possibility of meaning for Achilles and for his deepening of connection to other Greeks. Achilles' encounter with Priam even allows Achilles to extend his sense of community beyond that of other Greeks to the wider human community. The two men are tied to one another through their shared encounter with vulnerability and grief. In their meeting, words themselves fall short, and narrative is momentarily replaced with the sharing of a meal and the gaze of mutual recognition.

In a broad sense, the Iliad is a political work. ${ }^{2}$ Although the epic was written before the development of the $\pi o^{\prime} \lambda_{\iota s}$, and so in a strict sense is 'pre-political', nonetheless, the Iliad actively concerns itself with questions as to how the community is formed, its strengths and weaknesses, and the nature of the root of the bonds between human beings, both at the personal level and that of the larger community. The focal crisis of the book occurs when Achilles removes himself from the body politic, that is, from the community of Greeks who have agreed to work together for a common purpose in defeating the Trojans. Questions of authority, such as whether Agamemnon had the authority to claim Achilles' slave girl for himself, and whether Achilles has a moral, social, or political obligation to fight alongside the other Greeks, are central questions of the epic. The Iliad raises social and political questions for reflection by its audience.

2 See Dean Hammer, The Iliad as Politics (Norman, Okla.: University of Oklahoma Press, 2002), which argues that 'political' notions such as questions of authority and communal organization and proper rule are part of the Iliad, although no specific sense of $\pi$ ó $\lambda_{\iota s}$ as city-state ('political' in a narrower sense) had yet developed. See also Robin Osborne, 'Homer's Society', in R. Fowler (ed.), The Cambridge Companion to Homer (Cambridge: Cambridge University Press, 2004), 211-16. 
Among these questions is how death and mortality figure into human community. Conceptually, 'death' and 'mortality' are distinct. We can separate death, the facticity of life's end, from mortality, or the conscious awareness of ourselves as beings who will die. Homer presents not death per se, but rather the human awareness of our capacity to be wounded and to die, as a central constitutive part of the human social bond. War both strengthens this bond and presents the community with a host of problems as a result of it. Amongst the difficulties, most obviously, is the fact that war itself is a break in the social and political bond between the warring parties. Paris has violated the guest-host relationship in stealing away Helen, and his violation reverberates through the entire Greek political community. Yet, Homer treats the Trojans rather sympathetically, as equal human partners in the drama of war; not always simply as enemies deserving of death, but quite often as human beings caught in a larger series of interactions between the gods, men, and the passions of both. War is a fundamental threat to the political bond between societies and within the individual societies and families affected by war.

In addition, the death of any individual is a permanent and deep break in the social bond. The dead cannot participate actively in community, and those who lose the dead also lose significant social relationships and political status, as well as their connection to the beloved. Consider, for example, Andromache's poignant plea to Hektor not to go directly into battle, since, as she says, 'Hektor, thus you are father to me, and my honoured mother, you are my brother, and you it is who are my young husband' (VI. 429-30). ${ }^{3}$ Andromache's status within the Trojan community, and indeed her life's larger meaning, depend upon her relationship to her husband. Her pleas are returned by his own explanation that he is obliged to fight, lest his wife become enslaved to another: 'But may I be dead and the piled earth hide me under before I hear you crying and know by this that they drag you captive' (VI. 464-5). To her argument that her family relationship must be preserved and that his vulnerability threatens it, Hektor replies that it is precisely these relationships that the Trojans seek to defend in refusing to surrender, and in Hektor's refusal to hide while others fight. War both potentially threatens and protects the social relationships in which the warring parties exist, often producing

\footnotetext{
3 All translations in this chapter are from Homer, The Iliad, trans. Stanley Lombardo (Cambridge, Mass.: Hackett Press, 1997).
} 
considerable internal struggle in those who fight. In raising the sociopolitical difficulties that the human vulnerability to death presents, Homer does not shy away from death's grimness, nor from the losses of the dead and those with whom they were in relationship.

Awareness of one's own mortality presents specific challenges to the community, but also strengthens the bond between its members. Contrasting the reactions of mortals and gods as they are wounded in the Iliad provides a ready set of distinctions between the political communities of human beings who are vulnerable to mortality, and the divine community whose members are not. Golden has argued that the divine framework of the Iliad serves in part to increase our awareness of the fragility of human life and the challenge of prospering in such a world. Divine indifference to human beings reminds us of the increased importance of cultivating authentically human values in the midst of suffering and death. ${ }^{4}$ Contrasting the wounds of gods and of mortals similarly opens up the meaning of wounding and death for human beings.

That the gods are vulnerable, in the most literal sense of being capable of being wounded, may come as a surprise. In the light of Plato and the later Neoplatonic tradition that claimed that god by nature is wholly good and perfect, and therefore cannot change from a better state to a worse, our own cultural tendency is to think of the notion of immortal as commensurate with being invulnerable. In contrast, Homer portrays the gods as capable of injury, even at human hands. Hephaistos is mocked early on in the Iliad for his lameness, even as he serves the gods nectar in their goblets (I. 600). Both Aphrodite and Ares are wounded in battle by mortals, and complain fiercely of their pain. However, as one contrasts the gods' experience of their vulnerability with the experience of wounded or dying mortals, Homer reveals deep differences in the meaning and political significance of woundedness for the two.

Aphrodite is wounded by Diomedes' bronze spear. Her reaction is presented as that of a beautiful, but sensitive, woman whose beauty has been marred, and who complains primarily of the pain:

...the spear tore the skin driven clean on through the immortal robe

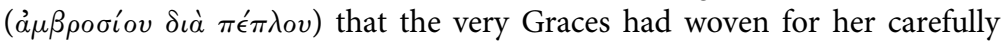

\footnotetext{
${ }^{4}$ Leon Golden, Understanding the Iliad (Bloomington, Ind.: Authorhouse, 2005), $1-15$.
} 
over the palm's base; and blood immortal $\left(\alpha_{\alpha}^{\prime} \mu \beta \rho о \tau o \nu ~ \alpha ̊ \alpha \mu \alpha\right)$ flowed from the goddess, ichor, that which runs in the veins of the blessed divinities; since these eat no food, nor do they drink of the shining wine, and therefore they have no blood and are called immortal. She gave a great shriek and let fall her son she was carrying... (V. 336-43)

The poet makes clear here that while she 'bleeds', that is, has the appearance of bleeding human blood, her veins are neither sustained by the same food and drink upon which human life depends, nor does its loss affect her life's length. Aphrodite easily loses control of herself and becomes self-concerned immediately upon injury. She drops her son, Aineias, without any hesitation, and while Apollo steps in to catch him, Aphrodite turns her attention entirely toward herself once injured. Returning to heaven with the assistance of her brother, she complains to Zeus that she has been wounded, on the grounds that (a) her wound hurts; (b) she has taken offence at its cause being a mortal; and (c) the mortals in question who wounded her are Danaans, whom she opposes in the war. Aphrodite uses her wound as an occasion to further her own cause, namely, opposition to the Greeks in the war.

Homer's presentation is not likely to produce much sympathy for Aphrodite on the part of his audience. Zeus checks Aphrodite's overly active participation on the battlefield. Other goddesses later mock Aphrodite for her excessive sensitivity and her lack of shame in favouring Paris, joking that she perhaps cut her hand on a pin on an Achaian woman's dress, after begging a new woman to fall in love with another favoured Trojan, as did Helen with Paris (V. 420-5). They laugh at her for her lack of control of her passion in loving mortals, as well as her inability to respond courageously to an act of war as Athena, or another god strong in battle, might have done. Neither is Homer's audience likely to be deeply moved by her injury, an effect that he accomplishes by constant juxtaposition of her immortal state with her injuries: her blood, we are reminded, is not real blood, but ichor, and it stains an immortal robe. Homer juxtaposes the imagery of the wound with the immortality of the wounded one, who is harmed but not capable of being destroyed by the wound. Aphrodite cares for Aineias' life, but she is just as quick to drop him as to pick him up once she is endangered. Her attitude towards her son seems fickle, a theme that much later Virgil will expand upon in his own Aeneid. Moreover, Aphrodite's main response to her injury is 
to appeal to her father, in part to complain of her own feelings, but also to further her political ends (and even those political goals are primarily informed by her personal, whimsical favouritism toward particular mortal men). She suggests that the Greeks, in particular, are liable to break proper boundaries and attack the gods, and so ought not to be supported in the war.

Contrast Aphrodite's injury to that of Menelaos when Pandaros hits him in a surprise attack. The colour of Menelaos' blood is described extensively, as a 'cloud of dark blood' gushes from his wound. Homer compares the blood to the dark red coloured ivory cheek piece for a horse, reserved for a king on account of its art. Menelaos' blood drips down his thighs, legs, to his ankles. Menelaos' ankles and thighs are described as shapely and beautiful, emphasizing his nobility even at the moment of injury. ${ }^{5}$ Instead of the merely identifying description of Aphrodite's 'blood' as ichor, here Homer gives us extensive imagery that allows us to engage imaginatively with Menelaos' experience. As Holmes has argued, blood is strongly associated with the vital energy of the hero, and its loss with the liminal status of a wounded man; continued bleeding is also used to communicate the pain of the victim to others. ${ }^{6}$ The difference between mortal and immortal wounding also communicates the difficulty of enduring bodily pain and so the heroism of human endurance of suffering. ${ }^{7}$

Agamemnon's response to his brother's wound also displays the relational and interpersonal element of suffering between mortal men. While only moments ago, Agamemnon was presented as a haughty, difficult leader who alienated Achilles for the sake of preserving his own pride, he is now deeply moved by his brother's injury: 'Agamemnon the lord of men was taken with shuddering fear $\left(\rho^{\prime}(\gamma \eta \sigma \epsilon \nu)\right.$ as he saw how from the cut $(\dot{\omega} \tau \epsilon \iota \lambda \hat{\eta} s)$ the dark blood trickled downward, and Menelaos the warlike himself shuddered in terror ( $\dot{\rho}^{\prime}(\gamma \eta \sigma \epsilon \nu)$; but when he saw the binding strings and the hooked barbs outside the wound, his spirit was gathered again back into him' (IV. 148-52).

Here, Homer juxtaposes the authority, strength, and courage of these two men with their fear. Menelaos rather quickly realizes his

\footnotetext{
5 Tamara Neal, The Wounded Hero: Non-Fatal Injury in Homer's Iliad (Bern: Peter Lang, 2006), 46-8.

6 See Holmes, 'Iliad's Economy of Pain'.

7 Holmes, 'Iliad's Economy of Pain', 151-84.
} 
wound is not fatal, and so is able to gather himself together again. But his initial reaction to his wound is not primarily its pain or any lack of honour incurred: the first response of both brothers is to see it as a sign of impending death. Agamemnon immediately questions his own role in bringing his brother to the point of injury: 'Dear brother, it was your death I sealed in the oaths of friendship, setting you alone before the Achaians to fight with the Trojans' (IV. 155-6). Agamemnon promises that his brother's death will not be in vain, and that he shall be successful in the war, but then adds poignantly, 'But I shall suffer a terrible grief (áxos) for you, Menelaos, if you die and fill out the destiny of your lifetime' (IV. 169-70).

Homer's parallel structure in the line translated above ('Agamemnon the lord...') especially communicates the way in which Menelaos' wound is also a kind of wound for his brother:

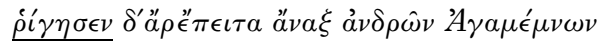

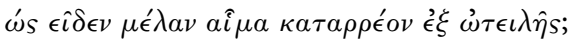

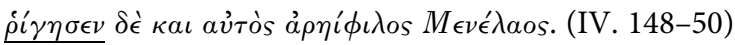

His use of $\hat{\rho}^{\prime} \gamma \eta \sigma \epsilon \nu$ in parallel lines, first with respect to Agamemnon's fear and then Menelaos' own, suggests a sympathetic response of brother to brother. In striking contrast to Aphrodite, whose woundedness leads her to abandon her son, Menelaos responds to his brother's sensitivity with care. He reassures him that the wound is not mortal as the war belt turned it aside from a more vulnerable spot; he has sympathy for his brother's fears and seeks to quell them. Agamemnon says he hopes Menelaos' assessment is right, and implores the doctor Machaon to come and assist. Each thinks of the well-being of the other first: Agamemnon of his brother's health, and Menelaos of assuaging his brother's fear. In this case, Menelaos' wound is an occasion for strengthening the bonds between Agamemnon and Menelaos, deepening their commitment both to the success of the war and to one another. ${ }^{8}$

${ }^{8}$ Here I disagree with Zanker's reading of this passage as revealing an egocentric Agamemnon overly concerned with his own glory. Agamemnon is concerned with the glory of the Greeks, but the familial and political are interconnected for Agamemnon: the well-being of his brother is genuinely and rightly connected to a desire to see glory for the Greeks, since the war was fought over Menelaos' bride. For Zanker's argument, see his contrast between Agamemnon and Achilles in grief, chapter 1 in Zanker, Heart of Achilles, 1-46. 
Here, Homer deepens our understanding of human vulnerability as profoundly interpersonal. Vulnerability to suffering and death are not simply individual experiences as is the immediate experience of pain. Rather, the possibility of loss reverberates from Menelaos to Agamemnon and back again, in their communication about his wound's meaning. Menelaos' wound becomes the occasion for Agamemnon's own suffering and fear for his brother and the Greek cause. In turn, Agamemnon's words lead to Menelaos' own reassurances, as the wounded one also sympathizes with his brother's experience of fear. Their mirroring of one another's suffering is simultaneously familial and political, as their interpersonal care is intimately linked to the question of whether Menelaos' wounds will also result in the loss of the war's moral significance.

Menelaos' wound is not simply an experience of individual suffering. Of course, Menelaos feels pain, but his interpretation of that pain, the meaning that he gives to it, is to understand his wound in terms of a larger narrative, a narrative with a social and political significance. Agamemnon understands Menelaos' injury as part of an open question of whether his injury and possible death will have a positive meaning. He insists, if Menelaos dies, that he must be successful in returning a powerful blow against the Trojans, otherwise 'at once the Achaians will remember the land of their fathers; and thus we would leave to Priam and to the Trojans Helen of Argos, to glory over, while the bones of you rot in the ploughland as you lie dead in Troy, on a venture that went unaccomplished' (IV. 171-5). Menelaos' injury thus is not only about his own pain, or even that of his family, but fits into a larger narrative about the Achaians and especially whether they will be able to restore honour after Helen's betrayal and the sacrifice of many men's lives. In particular, since Menelaos is Helen's proper husband, his death might mean the end of the Greek army's desire to fight for her return; as a result, Agamemnon fears, the Greeks might wish to return home. Menelaos' life's narrative will then not be one of a man who sought the return of his wife and his homeland's honour, but one of a man betrayed by his wife and later killed in a lengthy, unsuccessful war to return her to him. From Agamemnon's perspective, the time and manner of Menelaos' death is significant in terms of how that death gives shape and meaning to both his own life, and that of the others involved in it. His attitude towards Menelaos here is not only that of brother to brother, but also of king to king, both engaged in a war that has serious 
consequences for those who might sacrifice their lives for the sake of Menelaos and the return of Helen-a war grounded in an oath that various Greek leaders made to one another on behalf of the king and his marriage and also for the sake of Greek peace and stability.

The possibility of death has political significance for Agamemnon. It is not only a cause of grief. In light of the possibility of death, the sacrifice that the Greeks are willing to make for Menelaos and for one another possesses real significance. Thus, Homer presents vulnerability to mortality as the occasion for reflection upon the political and moral significance of the war; while Agamemnon is not a particularly reflective man by character, his brother's wound forces him to encounter questions of meaning about the war, his brother's participation in it, and his own sense of civic responsibility.

One might argue that Aphrodite also sees her wound as politically significant. After all, she attempts to use her injury as a means to harm the Greeks, when she suggests to Zeus that the Danaans-not simply mortals in general!-are now willing to injure the gods. However, Zeus is unswayed by Aphrodite's pleas to punish the Greeks precisely because her wound cannot result in her death. Zeus' narrative account of her injury locates it in a string of indignities that must occasionally be borne by the gods. He speaks: 'Have patience, my child, and endure it, though you be saddened. For many of us who have our homes on Olympos endure things from men, when ourselves we inflict hard pain on each other' (V. 382-3). Zeus offers Ares, Hera, and Hades as examples of gods who have had to endure pain and even the risk of a diminishment of power; but because they are immortal, their wound lacks the permanent significance of the 'end of a story'. The narratives of the gods are always open-ended; as a consequence, individual episodes of suffering and wounds are simply experiences of pain, not the possibility of a closure for a good or bad human life.

To put it somewhat differently, because their wounds cannot result in death, the gods' existences also lack the teleology present in the lives of many of the mortals of the Iliad. Divine lives lack an 'end' in two senses: first, the sense of a termination point, such that the significance of any single action is diminished; and second, their lives lack the significance of an 'end' in the sense of a $\tau \epsilon$ ' $\lambda$ os, a reason for existence that gives shape to the overall story and narrative of their

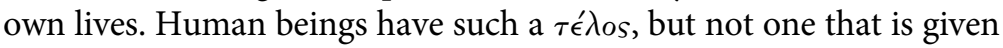
to human beings by the gods; neither does Homer present a strong 
sense of natural teleology, as will later thinkers such as Aristotle. However, Homer does tell the stories of human lives in the Iliad in terms of a constant forward movement in which each person seeks purpose and meaning in life in the face of the inevitability of death and the shape that death offers to a human narrative. Particular individual moments in a human life take on deepened meaning in their place in a story to which death offers definition. Paradoxically, the inevitability of life's termination is part of what grants purpose and meaning to the lives of those who live and die in the stories that will be told about them. Narrative accounts link the meaning of individual lives and deaths to a larger set of patterns and meanings within the Greek story.

Ares is also injured in battle, this time by Athena, who has 'put on the helm of Death' (V. 845). She leans in on Diomedes' spear so that it penetrates into Ares' stomach, and then wrenches it out again for maximum effect. Ares 'the brazen bellowed with a sound as great as nine thousand men make, or ten thousand, when they cry as they carry into fighting the fury of the war god' (V. 859-61). He, too, goes to Zeus, this time complaining of why the gods themselves fight among one another, aware that Athena is behind his injury. He complains that Zeus allows Athena to behave badly since 'yourself

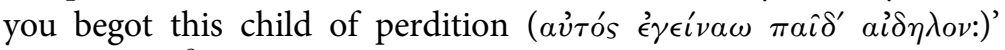
(V. 879-80). ${ }^{9}$ Zeus is far harsher with Ares than he was with Aphrodite, accusing Ares of being a whiner and a liar who enjoys quarrelling by nature (V. 889). Zeus does not attribute Ares' difficulty to his pain brought on by wounds, but to his warlike nature. Zeus lacks any fondness for Ares, but reluctantly heals him since Hera is his mother and Ares is his child (at least in the Homeric account). Ares is quickly healed and, wearing new clothes, sits down beside Zeus to observe the war.

Here Homer presents the wounding of the gods as an occasion for personal pain and suffering, but because death is not a possible outcome, one god has little, if any, care for the pain suffered by other gods. For Zeus, the wounds of others in his family are an occasion for reminding them of the relatively short-term consequences of injury; he also seeks to diminish tensions between them.

\footnotetext{
9 Thus, Ares ignores the role of Metis and attributes to Zeus a possessive privi-
} leging of Athena as his child. 
Both Aphrodite and Ares, once healed, return to their positions in heaven-they return to a point of stasis. Their injuries have a relatively limited place in the narrative they construct about their own existences, at least as Zeus describes it: their wounds must simply be 'endured' since other gods have also had to suffer, and because this is the way that life proceeds, for better or for worse. However, such wounds cannot result in death, or a deeply determining moment in a divine narrative. Moreover, the gods do not experience much sympathy for one another. Their injuries are not means of strengthening the bonds between the gods; if anything, we see greater division when Aphrodite and Ares make their complaints, which Zeus takes to be indications of weakness. But injury and death for the human beings in the Iliad have greater consequence and cannot be understood as idle complaints.

It is not simply the facticity of death that differentiates the mortal wounds of those who die in the Iliad. Homer presents the deaths of the innumerable men who fall as significant in ordering and defining the lives of the men. That is, the fact that the human being will die gives a definition and boundary to the story of a life. The possibility of telling a story about a human life with a beginning, middle, and end provides for the possibility of a teleology of meaning for each mortal being and for how his life fits in relation to the larger political community. As Homer presents these deaths, we find that a completely meaningful account of these men's lives does not fully come into being until their deaths. How each man is wounded, suffers, and responds to his suffering inflects and informs the community's understanding of his life's significance.

The sheer number of deaths in the Iliad is striking, but Homer takes care to name the wounds and deaths of those who suffer in battle. The poet does not present the deaths of the soldiers in quantifiable terms, but rather presents death as personal. Nearly every major character of the Iliad sustains a wound, with the exception of Ajax, and how each one responds to such physical wounding is part of how he shows his character and whether he is worthy of $\kappa \lambda \lambda^{\prime}$ os. As Tamara Neal has argued, injury becomes a mark of heroic identity. The injured body becomes a site of differentiation of one person and allows us to distinguish his character from among those who fight. How a character is injured, how he experiences the physical pain, the treatment he undergoes, and whether he receives divine favour are among some of the means by which the poet communicates the 
hero's heroism or lack thereof. ${ }^{10}$ Whether a blow penetrates the armour of an opponent or results in death communicates the warrior's strength. The ability to endure suffering or to exhibit self-control while undergoing the treatment of a wound also shows his moral excellence. These actions and responses often showcase the strength, self-restraint, and physical prowess of the hero. For example, the juxtaposition of numerous examples of Trojans who faint from wounding alongside examples of Achaians who maintain consciousness in similar circumstances communicates the greater strength of character of the Greeks. ${ }^{11}$

However, mortal wounding does not only display a warrior's virtues or strengths. Just as significantly, the Homeric narrative shows sensitivity to the warrior's weakness and finitude as a mortal being. Often the genuine loss involved in death is the most arresting part of Homer's narrative. Homer gives power to the sense of the loss through contrasting the moment of death with the relationships and the set of possibilities that had characterized a warrior's life before his death. That is, we often find a common (though not exclusive) pattern of a warrior's life as: (1) introduced in terms of those who have loved him, in childhood, marriage, or other intimate relationships; (2) followed immediately by a description of an injury; and (3) finally a proclamation of death. The immediacy of death that typifies Homeric accounts adds to its starkness.

Consider the death of Simoeis, a Trojan, in Book IV:

There Telemonian Aias struck down the son of Anthemion Simoeis in his stripling's beauty, whom once his mother descending from Ida bore beside the banks of Simoeis when she had followed her father and mother to tend the sheepflocks. Therefore they called him Simoeis; but he could not render again the care $(\theta \rho \epsilon \epsilon \tau \rho \alpha)$ of his dear parents; he was short-lived, beaten down beneath the spear of high-hearted Aias, who struck him as he first came forward beside the nipple of the right breast, and bronze spearhead drove clean through the shoulder. (IV. 473-82)

Homer primarily describes the death of Simoeis through natural similes, the effect of which is to remind the audience that human beings, while they strive for glory and honour, remain bound to the end of all natural beings, which exist in an ongoing cycle of life and death, in which impermanence of state is fundamental to human 
nature. Simoeis is not the only one deprived as a result of his death; his parents' deprivation, both of their child and of the $\theta \rho \epsilon \epsilon \tau \rho \alpha$ (care given to a parent in old age), is palpable. Thus, wounding and death are significant not only for how they communicate the warrior's good character and endurance, but also for how they reveal the reality of his mortal weakness and its meaning for the community, including unalterable loss. Homer's inclusion of Simoeis' death into a larger Greek narrative, however, makes his death part of an interpersonal and public story. Narration does not grant permanence to his life, but does move events that might otherwise have seemed to be contingent into the realm of the necessary, as if Simoeis' death has meaning through its being linked meaningfully to other events in the Greek story of war. In other words, even as Homer preserves the contingent and accidental nature of battlefield deaths, their narration also brings each person's life into relief through relation to a larger story endowed with meaning and purpose.

Achilles' shield also communicates this idea of the juxtaposition of human impermanence and flux with respect to particular persons or even communities (XVIII. 474ff.). The activities described on the shield, of course, are perennial human activities. Human agriculture, marriage, war, birth, and death all will continue. However, particularly in the context of a defeated Troy, where the Trojans will no longer continue to participate in these activities as a unified community, the permanence of these activities as human activities is not necessarily reason for consolation. ${ }^{12}$ Indeed, if anything, the shield that the immortal Hephaistos crafts for Achilles, who knows he is destined to die when he kills Hektor, while bearing this shield, only underscores the poignancy of Achilles' mortality. ${ }^{13}$ This shield, while it exhibits in its artistry the beauty of human life in all its variety, ultimately cannot protect Achilles from his fated death.

Homer continues to describe Simoeis:

He dropped then to the ground in the dust, like some black poplar, which in the land low-lying above a great marsh grows smooth trimmed yet with branches growing at the uttermost tree-top; one whom a man, a maker of chariots fells with the shining iron, to bend it into a wheel for a fine-wrought chariot, and the tree lies hardening by the banks of a river. (IV. 483-7)

12 Hammer, Iliad as Politics, 111-12.

13 Seth Schein, The Mortal Hero: An Introduction to Homer's Iliad (Berkeley and Los Angeles: University of California Press, 1984), 142. 
Similar passages occur with relative frequency in the Iliad, for example, when Alkathoos is introduced as beloved by the most beautiful and gifted wife at home, just before he is struck down and killed by a spear that penetrates the middle of his chest (XIII. 427-44). Euphorbos, too, is described as akin to a flower that briefly blooms, then is torn out of the ground and knocked down by the wind (XVII. 52-60).

The emotional resonance of such passages for the poet's audience arises in part from the skilful contrast between the particular care bestowed on an individual life, and the starkness of the abrupt transition from life to death. The details of Simoeis as treasured by his particular mother in his individual being contrast with the description of his death and the possibility that in war his life was simply used and then set aside once its utility had passed. Just as a chariot maker might use part of a tree, and literally see 'in' the tree the form of the not-yet-constructed wheel, Homer sets forth the possibility that Simoeis is part of an army where his life has been used more narrowly for a brief military purpose, the way that a tree is merely one small part of a chariot. The tree, once used for the chariot, is discarded and left abandoned beside the river. Similarly, the poet suggests, Simoeis is used for the war and then forgotten.

As Weil has argued, the epic reveals how the force of war converts a man from a person to a thing. She suggests two senses in which war makes a thing out of a person: 'Exercised to the limit, it turns man into a thing in the most literal sense: it makes a corpse out of him. ${ }^{\text {'14 }}$ In a second, but equally poignant sense, force has the potential to make warriors consider the enemy as a thing, an object rather than a being deserving of dignity and respect. In addition, the possibility of being set aside and forgotten after death is never fully overcome in the Iliad.

While Weil captures the dehumanizing elements of war, other elements of the epic seek to preserve the possibility of a respectful response to the dead. The possibility of mere utility of soldiers is tempered by two other, interrelated concepts that weave their way through the Iliad: memory and narrative. Being remembered takes place primarily through narrative and through the high respect

${ }^{14}$ Simone Weil, 'Iliad, or the Poem of Force', 3. See also an excellent account of Weil on the political force of words and listening in Dean Hammer and Michael Kicey, 'Simone Weil's Iliad: The Power of Words', Review of Politics 72 (2010), 79-96. 
offered to the dead at funeral rites. The importance and significance of caring for the body and mourning the dead in public is something that Greeks and Trojans alike consider significantly worthy of respect. Both when Patroklos dies and when Hektor is finally to be buried, the significance of burial of the dead necessitates a break in the usual structures of war and division of people into ally and enemy. The rules of engagement include a space for the suspension of hostility so that people may mourn.

The tradition of burying the dead and the significance of ensuring that each man is found and remembered lies on an even higher plane of customary law for the two warring parties than does the outcome of individual battles. When Hektor offers to fight one on one with a Greek in order to settle the war so that both sides can move on, he is careful to set the condition that the winning side return the body of the dead man so that the man's life might be properly mourned:

If with the thin edge of the bronze he takes my life, then let him strip my armor and carry it back to the hollow ships, but give my body to be taken home again, so that the Trojans and the wives of the Trojans may give me in death the rite of burning. But if I take his life, and Apollo grants me the glory, I will strip his armor and carry it to sacred Ilion and hang it in front of the temple of far-striking Apollo, but his corpse I will give back among the strong-benched vessels so that the flowing-haired Achaians may give him due burial and heap up a mound upon him beside the broad passage of Helle. (VII. 76-86)

Here Hektor recognizes the need for each side to give proper respect to the dead, an ethical demand that will be violated later in Achilles' harsh refusal to return Hektor's body. The rituals and obligations surrounding care of the dead require that even in the midst of war, civilization cannot be set aside entirely.

Homer's descriptions of human wounds, especially when set in strong contrast to divine wounds, display several important features of vulnerability. First, they highlight the interpersonal and political nature of wounds suffered in battle. Menelaos and Agamemnon's mirroring of one another's pain reflects the intertwining of the interpersonal and political significance of wounding. Menelaos' pain becomes Agamemnon's suffering, albeit in a mediated form. Their glances and words about the wound's significance deepen the bonds between them. Second, human wounds become the occasion for virtue in enduring suffering. While not all wounds result in death, 
that wounds are capable of resulting in death makes each wounding an occasion for the display of personal virtue. However, Homer also uses wounding as a reminder of human finitude and the real losses of war, as well as virtue. Third, wounds serve as reminders of death's inevitable limit on every life. This 'end' or point of finitude provides for the possibility of teleology. A story with a beginning, middle, and end creates narrative meaning for human communities in a way that divine wounds cannot. Vulnerability to wounding and death both deepens interpersonal and political bonds and creates the possibility of a meaningful narrative for those communities.

Homer's link between the inevitability of mortality and the meaning given by storytelling shapes even the larger structural elements of the Iliad. Schein usefully provides a framework of two complementary structural principles that guide the shape of the Iliad. ${ }^{15}$ First, he suggests that the Iliad possesses a symmetrical style that grants it a unity both within its individual passages and as a whole. As a whole, the epic possesses a symmetry in which the events of the first three books are mirrored in the events of the last three, as in how Book I's Agamemnon refuses to accept the supplication of Chryses and refuses to release his daughter for ransom, whereas in Book XXIV, Achilles accepts Priam's supplication and releases Hektor's body. Similarly, Book III features the duel of Menelaos and Paris, a theme reiterated in Book XXII when Achilles and Hektor battle one on one. ${ }^{16}$ Many individual passages also possess a static, circular, or parallel structure such as a 'ring' structure that gives each passage coherence and closure.

At the same time, Schein argues that much of the overall movement of the Iliad is an inevitable, unstoppable movement toward death and destruction, a movement seen in three distinct stages to the structure of the Iliad. We might see the Iliad as divisible into three sections, each of which features the virtues of the characters of Diomedes, Patroklos, and Achilles, respectively. Whereas Diomedes 
is a traditional warrior with respect for the gods and his own mortal limits, the character of Patroklos includes an element of dislocation and loss of identity, as Patroklos puts on Achilles' armour, is confused with him by others, and seems immersed in the characteristically aggressive manner of Achilles to press on even when the gods oppose him. This movement toward death culminates as Achilles fights against the river god, Skamander, proclaims that he would fight even against Apollo, were he able (XXII. 15), and eventually chooses death and honour over life and dishonour. ${ }^{17}$ This movement is a one-way movement, for death is not a state from which one can recover or return.

One might extend Schein's idea further and suggest that this dual structure of symmetrical and one-way movement characterizes something significant about the inherent structure of human vulnerability itself. On the one hand, we are all (like Achilles) bound for eventual death. The end of the story for each human being is essentially the same in that the narratives of our individual lives each come to an end. Endings are often abrupt and unexpected, and have profound consequences for families and communities. The temporal movement of life forward, to one's own death and through experiences of others' deaths, is unavoidable. On the other hand, Achilles' fundamental decision is to make key choices that influence how his life's story will be told. It is in the narrative meaning that is imposed on a lifeespecially, but not only, after the fact-that order and some degree of closure can come into being. He must decide whether he wishes to live a long, domestic, uneventful life, or a short but heroic one, and in choosing his short life but heroic death, both his life and his manner of death are tied to glory for Troy, and to his passionate, loyal friendship for Patroklos. His choice is explicitly one that is made in the light of what will be said about him, the meaning his life will take on within a narrative context. That life, though abruptly ended in one sense, is also given a structure and symmetry that his manner of death imposes on the shape of the larger story. In fact, the narrative of his life and death is not only what gives order to his own life; his story is also the centre of the story of the Iliad itself, a story which provides an entire community with a set of narrative meanings that ground its social and political identity as Greek. This, too, seems to be a point capable of extension to characterizing human vulnerability. While

\footnotetext{
17 Schein, Mortal Hero, 34-6.
}

This is an open access version of the publication distributed under the terms of the Creative Commons AttributionNonCommercial-NoDerivs licence (http://creativecommons.org/licenses/by-nc-nd/3.0/), which permits non-commercial reproduction and distribution of the work, in any medium, provided the original work is not altered or transformed in any way, and that the work is properly cited. For commercial re-use, please contact academic.permissions@oup.com 
individual events in a life may seem meaningless or not to fit into a larger order at the moment, the narrative shaping and interconnection of events after they have passed, and especially after an individual's death, lends an order to events not always discovered as they are occurring. Particular events are connected to other events and persons in a narrative structure that becomes meaningful for the larger community that tells and hears the story.

Achilles' vulnerability is the central condition not only of the possibility of his own life's meaning, but is also interwoven with the meaningfulness of the community of the Greeks. Nagy's well-known portrayal of Achilles' heroism, as located in his achievement of honour in killing Hektor at the price of his own life, is an insightful understanding of Achilles. ${ }^{18}$ But Homer tempers Achilles' love of honour with a portrayal of an Achilles who struggles with, and finally reconciles, his sense of his own vulnerability and is able to connect his acceptance of vulnerability to that of others. Vulnerability, too, is part of Achilles' virtue. ${ }^{19}$ Part of Achilles' glory (and the glory of the Greeks) lies in how Achilles comes to terms with his own finitude. Golden argues that Achilles must learn to overcome a kind of 'narcissistic rage' at suffering harm from Agamemnon; his generosity toward Agamemnon in Book XXIII reflects the slow culmination of spiritual and psychological development over the course of the Iliad. ${ }^{20}$

Indeed, Achilles' internal growth is a central part of the epic's insight into vulnerability. I argue that Achilles must also come to accept his powerlessness to prevent time from moving forward. Long ago, Zielinski argued that even simultaneous time is represented sequentially in the Iliad. ${ }^{21}$ The sequential nature of narrative description

18 Gregory Nagy, The Best of the Achaeans (Baltimore: Johns Hopkins University Press, 1979); see also Michael Clarke, 'Manhood and Heroism', in R. Fowler (ed.), The Cambridge Companion to Homer (Cambridge: Cambridge University Press, 2004), 74-80.

${ }^{19}$ Here I use the terms 'hero' and 'heroism' in conversation with Nagy's use of the term, that is, in an ethical sense and not in order to offer a historical analysis of literary character.

${ }^{20}$ Golden, Understanding the Iliad, 72-120.

${ }^{21}$ Originally in Thaddaeus Zielinski, Die Behandlung Gleichzeitiger Ereignisse, im Antiken Epos (Leipzig: Dieterich, 1901). Zielinski's emphasis was on the 'flattening out' of simultaneous events, as he posited that Homer was incapable of describing events simultaneously. However, my contention here is that the constant forward movement of action in sequential fashion poetically emphasizes the shortness of time and its forward movement. 
has the poetic effect of keeping the audience's sense of time as unremitting. The plot moves forward relentlessly as action follows upon action, even in Achilles' absence from the battlefield and field of politics. Achilles not only feels his pride damaged; he also initially resists the forward movement of time and remains in his anger about the past. For a while, he even behaves as if time has been suspended in his political and psychological removal from the Greeks, while physically being present in their midst. Only when he accepts the necessity of the one-way directionality of time and embraces his own temporal nature, can Achilles return to action. ${ }^{22}$

Nagy and Palmer have argued that Achilles' name is etymologically related to the concept of one who suffers pain or grief (äkos), both over the loss of his honour in the conflict with Agamemnon and over the death of Patroklos. ${ }^{23}$ If they are correct, then what implications might Achilles' name hold for understanding vulnerability in the Iliad? I suggest that Achilles is emblematic of an individual who struggles with pain and grief, at times responding to that grief through withdrawal, at times with rage. His excellence is not found in his achievements alone, nor only in his $\kappa \lambda \epsilon$ '́s. Instead, his virtue lies in part in his responses to his vulnerability, and his eventual acceptance of the inevitability of death and the loss of honour and of friends as part of living well. ${ }^{24}$ His story gains significance as Homer's audience sees the man struggle with dishonour, grief, and his own mortality, finally successfully resolving that struggle by epic's end. Achilles' final integration of his own pain in a virtuous manner takes place not primarily in his victory in battle, but rather in the meal

22 A fascinating account of the links between time and spatiality in Homer is to be found in Clay's analysis, which disputes Zielinkski's prioritization of the temporal in Homeric narrative. Using contemporary cognitive psychology as well as textual analysis, Clay argues that the 'space of the battlefield' has a priority over narrative time. See Jenny Strauss Clay, Homer's Trojan Theater: Space, Vision, and Memory in the Iliad (Cambridge: Cambridge University Press, 2011). See also Alex Purves, Space and Time in Ancient Greek Narrative (Cambridge: Cambridge University Press, 2010).

${ }^{23}$ Palmer first suggests that Achilles might have been a later combination of Akhilaos, or 'he whose host of fighting men has grief'. See L. R. Palmer, The Interpretation of Mycenean Greek Texts (Oxford: Oxford University Press, 1963). Nagy, Best of the Achaeans, chapter 5, lays out the etymological evidence with clarity and makes connections with the larger text of the Iliad.

${ }^{24}$ Hence Weil writes, 'Only he who has measured the dominion of force, and knows how not to respect it, is capable of love and justice.' Weil, 'Iliad, or the Poem of Force', 35. 
he shares with Priam after his rage is exhausted. Honour and victory in battle remain important elements of the Homeric man of virtue, but Homer also presents the need for a greater sense of vulnerability on Achilles' part as constitutive of ethical life. Achilles' own sense of vulnerability changes significantly through the course of the epic, and it is only at the epic's end that Achilles willingly embraces the fullness of his own vulnerable condition, and so also accepts that condition in others.

When Achilles is still unwilling to go into battle, even after Agamemnon has promised him many gifts as recompense, his former tutor and guardian, Phoenix, appeals to his own human weakness and suffering as part of what binds Achilles to him, and what ought also to bind Achilles to the other Argives who now suffer (IX. 438-95). Phoenix retells the story of his own life's events and how they resulted in his care for Achilles: he himself had to flee his own family and country after sleeping with his father's mistress as a result of his mother's pleading (IX. 446-56). While he loses a connection to his own father, he describes Peleus as having received him as a father does. In turn, Phoenix cared for Achilles as if he were his own son, a bond that is strengthened by Phoenix's inability to have children of his own. Phoenix is clear that the suffering he experienced from his childlessness is exactly what made the link to Achilles so strong, who he says was meant to 'keep hard affliction from me' (IX. 492-5). Images of Phoenix cutting up Achilles' meat into little edible chunks, and wiping up spit-up wine from his own shirt further emphasize Achilles' childhood dependence on Phoenix. This reminder of his dependence and weakness is clearly intended to soften Achilles' heart. He ends his story with a plea: 'Then Achilles, beat down your anger. It is not yours to have a pitiless heart' (IX. 496-7).

In other words, Phoenix connects Achilles' capacity to have pity for the Achaians, who are now suffering in battle with the Trojans, to Achilles' own capacity for weakness, and memory of his own dependence on others. Achilles needed others in order to survive, and the clear message here is that others now depend upon him. But his military strength and physical power are a less significant reminder of his military obligation than is his universally shared human dependence on others, just as Phoenix's deep bond of care for Achilles itself stemmed from the loss of a father and the loss of being a father to another. 
Phoenix's description of his temptation to parricide there also supports the larger theme of struggle with loss and suffering, although lines IX. 458-61 are most likely not Homer's own. While Plutarch includes them in Mor. 26, these lines are absent from the larger tradition of manuscripts and scholia. ${ }^{25}$ Nonetheless, even as later interpolations, these lines only deepen the nuances of Phoenix's sympathy for Achilles' internal struggles. There, Phoenix recalls his desire to kill his own father in order to defend his mother, a decision he was only prevented from carrying out by other relatives and their pleadings. There, Phoenix is presented as sympathetic to human weakness to anger in particular, and its limiting effects on rational, moral action. It is precisely because of his shared experience of dishonour and anger that Phoenix can speak to the same condition in Achilles, both able to sympathize with him and also to recommend a different course of action in the light of his past experience.

However ineffective Phoenix's pleas are with Achilles, they are bound to resonate with Homer's audience. Among the charges levelled at Achilles when he refuses to rejoin the Achaian community and fight against the Trojans is that he lacks care and pity ( $\left.\epsilon^{\prime} \lambda \epsilon \sigma s\right)$. For example, Nestor remarks, when Patroklos comes to visit the wounded who are resting on the ships, that Achilles is pitiless (XI. 664). His lack of care for his friends is directly paired with his lack of pity in Nestor's comments. The meaning of $\epsilon^{\prime} \lambda \epsilon o s$ in Homer is notably controversial. Konstan, for example, offers a more cognitive approach to pity, citing Aristotle's requirement that one be capable of understanding one's own vulnerability as a condition of its practice (Rhetoric 2. 8). Burkert, in contrast, argues that pity in Homer means acting in a particular way, rather than experiencing a particular emotion; in his view, expressions of pity are intended to communicate acting mercifully toward others. ${ }^{26}$ Both the expression of actions of mercy and feelings of pain for others seem to be facets of $\epsilon^{\prime} \lambda \epsilon o s$ over time.

${ }^{25}$ My argument does not depend upon the inclusion of lines 458-61, but as some authors, such as M. L. West's Teubner edition, do include them, it is worth noting their effect on the larger arc of Phoenix's claims regarding how his past suffering and anger informed his later care for Peleus and Achilles. For a more extensive argument on the difficulties surrounding IX. 458-61, see Bryan Hainsworth (ed.), The Iliad: A Commentary, Vol. III (Cambridge: Cambridge University Press, 1993), 123. See also Jasper Griffin, Iliad, Book Nine (Oxford: Oxford University Press, 1995).

${ }^{26}$ David Konstan, Pity Transformed (London: Bristol Classical Press, 2001) and David Konstan, The Emotions of the Ancient Greeks: Studies in Aristotle and Greek 
As Homer offers no explicitly philosophical account of pity, its meaning is inevitably more diffuse than in Aristotle's careful and nuanced account (which is taken up extensively in Chapter 3 in relation to the Philoctetes). For example, even the gods, who cannot fully sympathize with the situation of a dying man, take pity on human beings. At the start of Book XV, Zeus observes the wounded Hektor, struggling for breath and vomiting blood, and takes pity $\left(\epsilon^{\prime} \lambda \epsilon^{\prime} \eta \sigma \epsilon\right)$ on him (XV. 9-12). His pity is quickly followed with his realization that Hera has deceived him, in seducing him and inducing sleep so that Hektor might be wounded away from Zeus' sight, and he becomes angry with her. While he threatens to use his anger against Hera, in the end, his sense of pity for Hektor has a higher priority than his anger in action: Hektor is given a second wind and allowed to achieve greater glory before his destined end. Zeus' pity cannot arise from the possibility of imagining himself in Hektor's situation; yet, that he struggles with the conflicting demands of anger and pity suggests an emotional component to pity here.

Zeus' resolution of his own anger in favour of pity is particularly striking since Achilles must manage essentially the same sort of internal conflict. His continued anger at Agamemnon and feelings of betrayal initially overcome his sense of pity and friendship for his fellow Achaians, as Nestor's comment cited above makes clear. However, Achilles does not resolve his own conflict as rapidly as does Zeus. As Achilles slowly acknowledges and accepts his own vulnerability and that of others-particularly in the loss of Patroklos-his capacity to feel pity is actualized. To this extent, Achilles seems to act in accordance with the general Aristotelian point that awareness of one's own vulnerability to suffering is a necessary condition for experiencing pity for others, in human (though not divine) experience.

Schein has argued that Achilles' return to fight among the Greeks and become part of the social community again begins in part when in Book XI he observes the wounded being carried away. ${ }^{27}$ In particular, the wounding of the healer Machaon arouses Achilles'

Literature (Toronto: University of Toronto Press, 2006); W. Burkert, 'Zum altgriechischen Mitleidsbegriff' (Erlangen: Inaugural-Dissertation, Friedrich-AlexanderUniversität, 1955), 69-72, citing Il. V. 561, 610; XVII. 346, 352; Burkert cited in Elizabeth Belfiore, 'Review of David Konstan, Pity Transformed', Bryn Mawr Classical Review 14 April 2002, accessed online at <http://bmcr.brynmawr.edu/2002/2002-0414.html>, 21 August 2010.

27 Schein, Mortal Hero, 117.

This is an open access version of the publication distributed under the terms of the Creative Commons AttributionNonCommercial-NoDerivs licence (http://creativecommons.org/licenses/by-nc-nd/3.0/), which permits non-commercial reproduction and distribution of the work, in any medium, provided the original work is not altered or transformed in any way, and that the work is properly cited. For commercial re-use, please contact academic.permissions@oup.com 
interest, and so he sends Patroklos to go to Nestor to find out the identity of the unknown wounded man. Machaon's identity as a healer seems to have a special bearing on Patroklos' interest as well. Only a few minutes earlier, the narrator declares that Machaon's injury is particularly hard to bear because he is the one who heals others: 'A healer is a man worth many men in his knowledge of cutting out arrows and putting kindly medicine on wounds' (XI. 514-15). Patroklos, too, seems to be deeply affected by the prospect of a wounded healer. For Machaon's wounds open up the possibility that the wounds of others no longer will be healed if he dies. His vulnerability has a direct effect on the vulnerability of others. Patroklos is responsive to the demands of the immediate situation as he recognizes that time is essential, and heals those whom Machaon cannot attend.

In contrast, Achilles has acted as though he has all the time in the world to decide whether and when he might return to fight with the Achaians, as if time were somehow suspended, or the war remained at the same point in his absence. One such display of his utter removal is the scene of Achilles idly singing and playing the lyre while the war continues on (IX. 185). While Achilles is singing of heroes, the specific content of Achilles' song is absent from the narrative. One effect of its absence from the narration communicates that no content can compare with the sound of the war surrounding him.

Only when Achilles confronts and acknowledges that time continues and the effects of war continue, regardless of his own removal, does Achilles rejoin the battle. While his return only takes place after Patroklos' death, his witnessing of Machaon's wounding and enquiry into the identity of the wounded suggest a start of his awareness of the forward motion of the war. Achilles must learn to accept the sense in which human life moves always forward, and cannot return to the past. While the immortals can step aside, return to Mount Olympus, and play music while the wars continue, for Achilles to remove himself does not cease the war itself. Sending Patroklos in his stead to find out the identity of the wounded man initially serves as a halfhearted substitute for his own engagement, until Patroklos finally dies in his place, wearing his armour, and Achilles can avoid the war's forward movement no longer.

Vulnerability and temporality are here interlinked. The wounding and deaths of others are powerful reminders that time moves forward and that temporality cannot be escaped, as Patroklos recognizes but 
Achilles seemingly cannot. Achilles' singing away from the other Greeks while the war rages on is not simply a sign of his anger; it is also a refusal to acknowledge the movement forward of his own community's situation, as the war continues and deaths mount whether he participates or not. Achilles refuses to acknowledge a kind of vulnerability to time itself; such avoidance has profoundly negative political consequences. Saxonhouse has argued that part of what Achilles must learn is that the inequitable distribution of goods and honours is part of ordinary human life and must be accepted as an inevitable limit. ${ }^{28}$ Achilles refuses to accept ordinary limit in his demand for justice for the slight against him; this avoidance of limit extends even into an avoidance of the temporal itself.

In contrast, after Patroklos discovers Machaon's identity, he engages with the wounded before him. Patroklos takes on his work in tending to the wounded Eurypylus. Patroklos is an interesting figure at this juncture in the poem, as in turn he takes on two different and even diametrically opposed identities: first, that of the gentle healer, when he takes the place of Machaon, then that of wrathful warrior, when he puts on Achilles' armour and fights. As Briseis remarks later over Patroklos' corpse, Patroklos was an exceptionally gentle man by nature. But we also see his capacity for fury in battle as he kills many Trojans with fierceness reminiscent of that of Achilles before meeting his death. Twice Patroklos takes on the social role of another member of the community in their absence: in the healer Machaon and the warrior Achilles.

Perhaps surprisingly, these warrior and healing roles are connected not only in Patroklos, but also potentially in Achilles. Patroklos possesses the technical ability to tend to Eurypylus' wound because of his link to Achilles. Eurypylus says that Patroklos can help him since Achilles knows which medicines to place on the wound once it has been cleaned because the centaur Cheiron told him of these medicines (XI. 830-1). Patroklos' own knowledge of healing comes from Achilles. Patroklos remarks that while he is en route to deliver a message to Achilles, he will delay his return in order to tend to Eurypylus. He remarks, 'I will not leave you in your affliction,' before proceeding to remove the arrow, clean the wound, and apply a root

${ }^{28}$ Arlene Saxonhouse, 'Thumos, Justice, and Moderation of Anger in the Story of Achilles', in Catherine Zuckert (ed.), Understanding the Political Spirit (New Haven: Yale University Press, 1988). 
that makes pain disappear. Patroklos tends not merely to the healing of the wound, but also to Eurypylus' need for attention and the relief of pain. He 'entertains him with words' and rests in his tent, despite Achilles' expectation that Patroklos will return with news from the front (XV. 393-5). He only leaves Eurypylus in order to go to persuade Achilles to re-enter the war, in the hope that 'the persuasion of a friend' might induce Achilles to do so (XV. 404). Thus, he shows his ability to be responsive to time and to act as is appropriate to the present moment, displaying a kind of moral kairos that Achilles seems to lack.

Although much has been said about how Patroklos' death foreshadows the death of Achilles, ${ }^{29}$ much less has been said about the link between Patroklos and Achilles and those with knowledge of healing, no doubt because Achilles has seemingly abandoned an interest in participating in the activity of healing others. To this extent, Patroklos integrates his role as healer and as warrior in a way that Achilles seemingly cannot, realizing the interconnectedness of wounds and healing and their mutual centrality to human experience. Achilles, while possessing the formal knowledge of some medicine, lacks a strong sense of care that Patroklos possesses. He ceases to act on his knowledge of healing, denying the reality of others' vulnerability until Patroklos' death. At the same time, his continued anger at his mistreatment by Agamemnon also paralyses his participation in the battle as a warrior, in a way that is not true for Patroklos. Only when Patroklos dies-exhibiting his vulnerability and the impossibility of delaying time and the war's forward motion-does Achilles return to being a man of action.

Patroklos exhibits a kind of care for community that is linked to a sense of his own vulnerability that Achilles lacks, immediately before he dons Achilles' armour and fights on behalf of his friend. Patroklos recognizes that there is something inhuman about Achilles even in his pleas that Achilles return to battle. He challenges Achilles: 'Pitiless: the rider Peleus was never your father nor Thetis was your mother but it was the grey sea that bore you and the towering rocks, so sheer the heart in you is turned from us' (XVI. 33-5). Here, Patroklos questions whether Achilles is really human, or as unmoving as a stone or water, which endure far longer than human life, but which lack any sense of

${ }^{29}$ For example, see Nagy, Best of the Achaeans, 33.

This is an open access version of the publication distributed under the terms of the Creative Commons AttributionNonCommercial-NoDerivs licence (http://creativecommons.org/licenses/by-nc-nd/3.0/), which permits non-commercial reproduction and distribution of the work, in any medium, provided the original work is not altered or transformed in any way, and that the work is properly cited. For commercial re-use, please contact academic.permissions@oup.com 
connection to others. That is, the image of towering rocks makes an appeal to Achilles to remember that he is not as invulnerable as stone, and that it is exactly his sense of his own humanity and connection to others that ought to lead him to feel pity again.

Patroklos pleads with Achilles at least to allow him to borrow his armour and enter the battle as if he were Achilles, not out of a desire for his own glory, but to be a 'light' to the other warriors. He sees Achilles as a potential symbol of hope and rejuvenation, even as Achilles continues to mull over his wounded honour. Achilles agrees to the plan so that he might gain glory and honour, but even those only become means of somehow gaining more gifts and more recognition from others in the community of the terrible wrong done to him by Agamemnon. Achilles is literally lost in this past slight, and seemingly cannot move forward from this event, until he feels that it is rectified. His tóros about his own life is shaped entirely by his immediate $\pi \alpha \dot{\theta} \theta$ s, and that $\pi \alpha \dot{\theta} \theta$ os keeps Achilles oriented to the past. ${ }^{30}$ Achilles demands that Patroklos only make an appearance rather than fight the Trojans, presumably partly out of a sense of protection for Patroklos, but also out of a strange fantasy that all the other Greeks might die, so that he and Patroklos alone might defeat Troy (XVI. 97-100). Thus his disengagement with the present also results in an unrealistic understanding of his own and his community's future.

Patroklos' role in the Iliad partly functions to highlight a similar division within Achilles, one that he is unable to bridge within himself in an integrated way. For much of the Iliad, Achilles is unable to make sense of his vulnerability and mortality in a way that gives ordered meaning to his life. He realizes that honour in battle, and glory, while goods, do not diminish the finality of life, nor do they replace the evil that is the loss of life. While Achilles' view of honour is tested when Agamemnon unjustly takes away the spoils of war from him, this difficulty with the fickleness of honour is linked to Achilles' sense of his mortality and displacement from the community. Achilles is correct that honour and glory are not lasting, and are capable of

\footnotetext{
30 See P. Christopher Smith, 'Nietzsche and Gadamer: From Strife to Understanding, Achilles/Agamemnon to Achilles/Priam', Continental Philosophy Review 35 (2002), 379-96. Smith demonstrates how Achilles' argument with Agamemnon is grounded entirely in $\pi \alpha \dot{\theta} \theta$ os. I would suggest that Phoenix recognizes that $\pi \dot{\alpha} \theta$ os is at the root of his ideas, so makes an appeal to $\pi \alpha \dot{\theta} \theta o s$, not reason alone, in attempting to persuade Achilles.
} 
being lost as easily as they are gained. This poses a real dilemma for Achilles, for he is neither respected for his leadership by Agamemnon, nor as a leader is he obliged to obey some higher authority, for example, as Achilles' own soldiers must dutifully obey him. Achilles' source of meaning in honour and social bond has been violated. He refuses to pay the price or make the sacrifice of risking his life for an unknown or at least unstable reward. Achilles' absence from the battle to some extent staves off, but does not solve, his difficulty in resolving meaning in life in the light of the limitedness of glory and honour. ${ }^{31}$ Patroklos' death, however, forces Achilles to encounter his difficulty, rather than remaining in a place where it can be perpetually avoided. As Hammer phrases it, when confronted with the body of Patroklos, Achilles finds that he can no longer act as one who is self-sufficient, but 'now places his life in a relational context'. ${ }^{32}$ But his return to the war does not resolve, but at first only exacerbates, his dilemma, as Achilles moves from complacency to rage.

Even in mourning Patroklos, Achilles denies his ability to be affected by his mortality. After Patroklos' death, he responds to Odysseus' encouragement to eat with the claim that they ought all-not only he, Achilles, but all the Achaians!- to go forth into battle without eating until Patroklos' death has been paid for (XIX. 205-14). Odysseus kindly reminds him that men cannot fight ably when hungry: no matter how ready their hearts may be for battle, their limbs will grow weary if not well fed. But he also adds, somewhat more starkly, 'we must harden our hearts and bury the man who dies, when we have wept over him on the day, and all those who are left about from the hateful work of war must remember food and drink' (XIX. 228-31).

In other words, acceptance of a fallen friend's death is necessary for continuing on in life. The dead body before the completion of a funeral is in a liminal condition, between life and the finality of death, from the point of view of the mourners. In being present to the body, the mourners are also in this liminal space. ${ }^{33}$ But the liminal

\footnotetext{
31 Note, for example, how Achilles fails to respond to Odysseus' entreaties to pity him, which Hammer suggests is due to Achilles' belief that suffering for others no longer holds moral worth, now that his honour is not respected by others. See Hammer, Iliad as Politics, chapter 4.

${ }^{32}$ Hammer, Iliad as Politics, 178.

33 James Redfield, Nature and Culture in the Iliad: The Tragedy of Hector (Durham, NC: Duke University Press, 1994), 181-2.
} 
nature of mourning in a ritualized time and space has a purpose, which is eventually to allow forward movement. The mourning, sacrifice, and even meals that the mourners eat serve in part to memorialize and to honour the dead. However, these same activities also allow for a bounded space for grief for the living so that mourners can eventually move to other activities and relationships, integrating past relationships and events into a new reality. Achilles continues to resist this forward movement. He refuses to eat, and eventually Athena feeds him ambrosia in his sleep, so that he will have the strength to fight.

To this extent, Achilles acts as though he is not an embodied being. His foreknowledge of his own death, that it will follow swiftly upon Hektor's death, allows him to escape Odysseus' difficult, but realistic, claim that part of the task of living is to mourn and then move forward with life in part through leaving behind (at least to some extent) the dead. Later, when Achilles does begin to move forward, he allows the fullness of rage to consume him in battle; the poet's voice describes him as 'more than human'. For example, in Book XX, as the poet describes Achilles' swift killing of one Trojan after another, he adds, 'As inhuman fire sweeps on in fury through the deep angles of a drywood mountain and sets ablaze the depth of the timber and the blustering wind lashes the flame along, so Achilleus swept everywhere

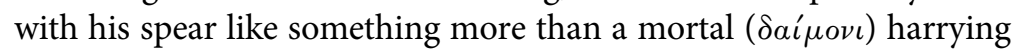
them as they died, and the black earth ran blood' (XX. 490-4). Homer's description of Achilles as like a $\delta a i_{\mu o v}$ implies that Achilles behaves as though he is something other than human, a $\delta a i \mu o v$ or spirit, a part of the supernatural world. Yet, the truth of his existence is his mortality; he is not a $\delta a i^{\prime} \mu \nu v$, as he will soon find out in the encounter with the true river $\delta a i_{\mu o v}$, Skamander. Although Achilles is descended from the goddess Thetis, her immortality does not protect him here. Still, Achilles rages after the Trojans, demanding that their deaths pay for his friend Patroklos' death, but his words indicate that he knows no payment will suffice to rectify the loss. When Lykaon, a former slave who had once before been captured and sold by Achilles, meets him again, Achilles is merciless to the suppliant man. But his speech is strangely tinged with the claim that they are still friends, even at the moment that he kills him:

Now there is not one who can escape death, if the gods send him against my hands in front of Ilion, not one of all the Trojans and beyond others the 
children of Priam. So friend ( $\phi^{\prime} \lambda_{o s}$ ), you die also. Why all this clamour about it? Patroklos is also dead, who was better by far than you are, and born of a great father, and the mother who bore me immortal? Yet even I have also my death and my strong destiny, and there shall be a dawn or an afternoon or a noontime when some man in the fighting will take the life from me also either with a spearcast or an arrow flown from the bowstring. (XXI. 103-13)

Achilles addresses Lykaon as a friend, a píxos. What kind of 'friendship' is this, between a man twice captured by Achilles in war, now sent to his death to pay a ransom for the death of Patroklos? Achilles' chilling words suggest that he sees all human beings as sharing a common friendship in violent death. Just as Patroklos shall die, so shall Lykaon, and eventually Achilles, too. Achilles defines his and others' lives' meanings in terms of their inexorable movement to death, not only death generally, but the violent death that characterizes much of male life in this time of war. Achilles is not angry specifically at Lykaon, so much as determined to 'resolve' the conflict between finding life meaningful and accepting human death, by participating as much as possible in the futile, angry violence, as if by embracing its futility more fully and more passionately, he might somehow defeat its power. He understands meaning to be found in brute power, as when he remarks to a descendant of the river god after slaughtering him that, as a descendant of Zeus, he surely would win, since Zeus is more powerful than a river god, and so he as his descendant must also win over any descendant of the river.

That Achilles battles with a river god, Skamander, is not surprising, as a river embodies constant change. Each time that Achilles tries to fight against the river, he finds himself defeated precisely by the river's ability to change shape, to produce a wave above him, to crest where he does not expect a wave to crest, or to wear out his knees with its constant flow (XXI. 233-72). Achilles eventually feels as though he were reduced to being only a boy by the river's power, and indeed, there is a good deal of truth in his proclamation that he is childlike and helpless against the torrent of the river. The torrent, not only of the river, but of many events outside of his control-beginning with his loss of Briseis and social place, through his close friend's death, and his own powerlessness over his destiny to die once he kills Hektor-all overwhelm Achilles, who now can no longer believe that his power to kill can rescue him from his true powerlessness in the face of death. His strength serves him no more, and it is only the 
reassurances and actions of Poseidon, Athena, Hera, and Hephaistos that stop Skamander.

Achilles, of course, is brutal with Hektor as well, refusing Hektor's civilized offer to promise one another to return one another's bodies. Achilles refuses, promising him that he will not return the body, and when he begins the fight, it is to Ares-the god of irrational, raging war-and not Athena, that he appeals. When Hektor dies, Achilles drags his vanquished opponent's body around Troy, in full view of everyone. The seriousness of Hektor's lack of a funeral is emphasized in Andromache's fainting and mourning the unperformed rites for his body, a description that occurs immediately before Patroklos' funeral rites, as if to emphasize the inhuman nature of Achilles' treatment of the corpse.

It is only when Patroklos appears to Achilles as a ghost, and asks specifically to be buried, so that his soul might pass over to Hades, that Achilles begins to resolve his inner conflict about mortality. Patroklos' account of his need to cross over, and to be buried, is also indicative of Achilles' need to allow Patroklos to move from the realm of life into a death from which he will not return. Achilles finds this experience of an apparition, or dream, sufficient to allow him finally to bury Patroklos, and accept the reality of his friend's death. His acceptance of loss and the inability to withstand the forward movement of time allows Achilles to sympathize with Priam and finally to return Hektor's body.

\section{III}

The decision to return Hektor's body and to host Priam is key to Achilles' resolution of his difficulty with vulnerability. Homer dramatically gives force to the meal as the pinnacle of Achilles' resolution of his internal strife. ${ }^{34}$ Just as Achilles allows himself to eat for the first time at Patroklos' funerary rites, we see Achilles eat with his enemy.

\footnotetext{
${ }^{34}$ For an excellent account of the development of relationship between Achilles and Priam, see Marjolein Oele, 'Suffering, Pity and Friendship: An Aristotelian Reading of Book 24 of Homer's Iliad', Electronic Antiquity 14 (1) (November 2010), 52-65. I am deeply indebted to many of her insights, which have been influential for my own thinking on the passage. See also Rachel Bespaloff's 'Priam and Achilles Break Bread', in Weil and Bespaloff, War and the Iliad, 79-85.
} 
When Priam comes to retrieve Hektor's body, Achilles acknowledges a need for food and the continuance of life, not only for himself, but also for his vanquished opponent. ${ }^{35}$ This moment of offering food to Priam is the moment in which Achilles in deed acknowledges his shared mortality with his enemy, and so also acknowledges it to himself. It is at precisely this moment that Achilles is able to be humane, and also able to be more fully human.

Eating is an acknowledgement of mortal dependence on what changes in the world of the Iliad. Homer is explicit about the relation between the food of human beings and human mortality when the gods remark that they ought not to be too deeply invested in mortal beings' affairs. Apollo cautions Poseidon:

Shaker of the earth, you would have me be as one without prudence if I am to fight even you for the sake of insignificant mortals, who are as leaves are, and now flourish and grow warm with life, and feed on what the ground gives, but then again fade away and are dead. Therefore let us with all speed give up this quarrel and let the mortals fight their own battles. (XI. 462-7)

Apollo sees human mortality as linked to the mortality of plant and animal life. The food that they eat is one living thing that dies in order to sustain the life of another, who himself is also destined to die. ${ }^{36}$ To eat, then, is to acknowledge one's dependence on the body, and one's link to other mortal beings. To share a meal with another also connotes intimacy with another who is mortal, like oneself. While earlier Achilles had spoken of his $\kappa \lambda \epsilon$ є́os as that which will be unfailing

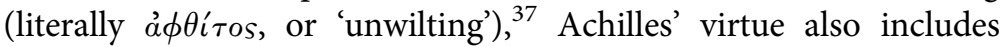
acknowledgement of the value of that which does wilt, die, wither. In the final scene, the temporary and mortal meaning of food intersects with the cultural and lasting ritualizations of hospitality and a shared meal. Only in the sharing of conversation and eating with Priam do we finally see Achilles come to terms with his mortality, and return to a life of a mortal, social, political being.

35 Redfield suggests that the warrior in the Iliad has left culture and entered into nature; in this scene, Achilles returns to civilization and its rituals. See Redfield, Nature and Culture, 218-23.

${ }^{36}$ See Neal, Wounded Hero, 156-7.

37 Nagy connects Homer's use of a $\phi \theta i$ íos to a direct opposition of what is $\phi \theta_{\imath}-$ i.e., a root of terms used to denote the decay of plant life, for example, Pindar's usage of the wilting of crops in the Paen 9. 14. See Nagy, Best of the Achaeans, 176 and 183-6. 
Priam comes to Achilles in supplication for his son's body, which Achilles has agreed to give up after his mother Thetis sends word that Zeus demands it. Priam compares himself to Achilles' own father: 'Honour then the gods, Achilleus, and take pity ( $\left.\epsilon^{\prime} \lambda \hat{\epsilon}^{\prime} \eta \sigma o \nu\right)$ upon me remembering your father, yet I am still more pitiful ( $\left.\dot{\epsilon} \lambda \epsilon \epsilon \nu \sigma^{\prime} \epsilon \rho o ́ s\right)$; I have gone through what no other mortal on earth has gone through; I put my lips to the hands of the man who has killed my children' (XXIV. 503-6).

The effect on Achilles is to grieve for his own father, the poet tells us. Achilles finally experiences pity. His pity arises primarily not from an intellectual or moral claim that Priam ought to have his son's body back. Instead, Achilles experiences pity when he willingly encounters his own and his father's pain and can relate that pain back to Priam's pain as a father. Achilles makes a double move of identifying not only with his own father's sorrow that will result from his own death, but also with Priam as akin to Achilles' father. ${ }^{38}$ In other words, Achilles feels pain on behalf of his father in anticipation of his own death. This anticipatory grief opens up a space that allows Achilles also to feel pain for Priam and so to experience pity. ${ }^{39}$ His act of engaging in sympathetic grief is an essentially social move that allows Achilles to engage with the meaning of his own death-and life-from the point of view of being his father's beloved son. Achilles can see his own life's worth not simply in terms of its termination, that is, not simply in terms of his death. His understanding of himself as the son of Peleus is also his acceptance of his identity as a mortal man. Notably, he does not mourn for Thetis, his immortal mother, and her impending loss, but for Peleus, his mortal father. His grief for himself as a mortal man is intertwined with his grief for Patroklos (see XXIV. 508-12). ${ }^{40}$

What is moving and surprising is that Priam effectively stands in for Achilles' father in his absence. Priam becomes, in the eyes of Achilles, akin to his own father mourning his death, while Priam mourns the loss of Hektor in the presence of his son's killer, who is also destined soon to die. Priam and Achilles thus stand in a sort of

38 Oele, 'Suffering, Pity', 9.

39 Kevin Crotty, The Poetics of Supplication: Homer's Iliad and Odyssey (Ithaca, NY: Cornell University Press, 1994), 70-88.

40 As Zanker argues, once Patroklos dies, Achilles exhibits more than any other character a desire for $\kappa \lambda \epsilon$ '́s that is grounded in affective bonds to others, and not merely glory that is centred around himself. See Zanker, Heart of Achilles, chapter 3. 
mournful imitation of a father-son relationship. ${ }^{41}$ Homer remarks, 'The sound of their mourning moved in the house' (XXIV. 512), further underscoring the imagery of Priam and Achilles sharing a house together, through a kind of unity that is reached only in the acknowledgement of each of their losses. Such unity arises only through a shared experience of pain and acceptance of suffering as the plight of all mortals. ${ }^{42}$

Notably, Achilles, whom Homer had referred to time and time again as pitiless, is said to take 'the old man by the hand, and set him on his feet again, in pity for the grey hair and the grey beard' (XXIV. 516). ${ }^{43} \mathrm{He}$ arranges for Hektor's body to be returned, and then invites Priam to eat with him, though he himself had refused to eat after Patroklos' death before. He states the demand that they eat in the first person plural: 'Come then, we also, aged magnificent sir, must remember to eat, and afterwards you may take your beloved son back to Ilion, and mourn for him; and he will be much lamented' (XXIV. 617-20). This same Achilles, who had refused to eat in grief for Patroklos, now eats a meal with another who has suffered a similar loss, and encourages Priam to do the same. ${ }^{44}$ Achilles displays what Zanker helpfully terms 'magnanimity'. ${ }^{45} \mathrm{He}$ offers the example of Niobe, the mourning mother turned to stone by Zeus because she refused to stop mourning, and so remained forever in her unchanged state. ${ }^{46}$ Like Niobe, Achilles and Priam alike will soon come to an end;

${ }^{41}$ Interestingly, Hermes also likens Priam to a beloved father in Book XXIV (XXIV. 371). See Pratt, 'Parental Ethos', 39 for her insightful analysis of the ethos of parent-child relationships in the Iliad.

${ }^{42}$ See also Jinyo Kim, The Pity of Achilles: Oral Style and the Unity of the Iliad (Lanham, Md.: Rowman and Littlefield, 2000), 146-51.

43 Oele notes the beautiful combination of intimacy and distance in Achilles' taking of Priam's hand, and his later pushing him away. As she argues, their relationship moves in the direction of almost a sort of friendship through their intimate sharing of suffering here. See Oele, 'Suffering, Pity', especially 61-3. Hammer also emphasizes the sense in which mutual grief opens up for Achilles the possibility of imagining his father Peleus' grief. He thus becomes vulnerable also to his own father's suffering. See Hammer, Iliad as Politics, 182-7.

${ }^{44}$ Here eating itself functions as an act of union. See Jasper Griffin, Homer on Life and Death (Oxford: Oxford University Press, 1980), 16.

${ }^{45}$ See Zanker, Heart of Achilles, 127.

${ }^{46}$ Malcolm Wilcock, A Companion to the Iliad (Chicago: University of Chicago Press, 1976), 272-3. As Wilcock explains, Homer is inventive here in his tale of Niobe, as the ordinary story would not allow for her to eat or dry her tears, since Zeus turned her to stone. Such a retelling only underscores the Homeric point that eating requires a kind of engagement with temporality. 
but they also must eat, and continue to participate in the activity of human life and the communion of other persons, lest they become no more than stones.

As they eat, they gaze upon one another, focusing not upon one another's grief, but upon the other's beauty: Priam sees Achilles as possessing looks akin to a god, and Achilles in turn sees the brave look in Priam's face. ${ }^{47}$ In gazing at one another, each participant sees not only the other, but also the other's apprehension of himself. Achilles can see not only that Priam suffers, but also that Priam is appreciative of Achilles' own suffering. Priam recognizes his own courage through observing its apprehension in Achilles' expression. This mutual gaze allows each to see in the other a being with worth and value, even in the midst of great suffering; to some extent, we might say that the mutuality of the gaze, which both must have recognized, also confirms each man's own worth when his enemy thus looks upon him in wonder. Here Homer's poetic voice moves away from formal, ritual elements of hospitality to a description of this interpersonal encounter between two particular individuals. Indeed, words themselves seem to have limited value for Achilles and Priam, and are replaced with the simple actions of eating and looking at one another. The value of the mutual gaze emphasizes more than a cultural practice; Homer presents the mutual vulnerability of two human beings to one another. Bespaloff suggests that the beauty of Achilles itself is a moment of redemption, insofar as his beauty touches something of the eternal in the midst of the temporal and fleeting. ${ }^{48}$ And it is in this affective sympathy for one another that the possibility of a rational resolution of the proper disposal of Hektor's body becomes a reality; the emotional interactions of the two quiet Achilles' rage, and make possible dialogue with Priam. ${ }^{49}$ Such an interaction between the gods and human beings, or even between gods, seems almost unimaginable, for the gods are untouched by the depth of suffering experienced here, since any moment of pain remains only a moment in eternity.

\footnotetext{
47 As Pratt notes, the narrator here also emphasizes how god-like Priam is. Pratt, 'Parental Ethos', 40. Oele, 'Suffering, Pity', 62-3.

48 Bespaloff, 'Priam and Achilles Break Bread', 83.

49 Here I think Smith is entirely correct in suggesting that Achilles' struggle over whether to return the body to Priam is not about intellectual assent to beliefs or propositions, but an internal struggle of emotions. See Smith, 'Nietzsche and Gadamer', 391-3.
} 
Achilles gives Priam a place to sleep, and guarantees a space of twelve days in which to mourn Hektor, before which he will not allow the Achaians to disturb the Trojans. As we know, the Iliad ends not with the sacking of Troy, although the audience knows this will inevitably occur, but rather with the ongoing practice of human life in the midst of death. While Homer points to the defeat of Troy and the death of Achilles, the resolution of the epic ends with a shared meal between enemies and the remembrance of Hektor. Like the art of Achilles' shield, and its engagement with human life in its joys and sorrows, Homer's poetic art allows life to continue on for the living. The vulnerability of human life, while acknowledged to contain much suffering and pain, is also affirmed as the locus of social life not only in the funeral rites, but also in these simple social acts of eating and conversation that require an affirmation of life even in the midst of loss and destruction. 
This is an open access version of the publication distributed under the terms of the Creative Commons AttributionNonCommercial-NoDerivs licence (http://creativecommons.org/licenses/by-nc-nd/3.0/), which permits non-commercial reproduction and distribution of the work, in any medium, provided the original work is not altered or transformed in any way, and that the work is properly cited. For commercial re-use, please contact academic.permissions@oup.com 


\section{2 \\ Oedipus and Theseus at the Crossroads}

Oedipus Rex is a play about the limits of human wisdom, one that explores the themes of ignorance, knowledge, and knowledge of one's own ignorance as a kind of wisdom through multiple metaphors. One such metaphor is the theme of blindness and its accompanying wounds. To begin, Oedipus claims that the blind Teiresias is blind not only in sight, but also with respect to his prophecies, when we know that the sighted Oedipus is blind. And we also know that it is after Oedipus learns the truth that he will lose his sight, and be blinded at his own hands. At the beginning of Oedipus Rex, we find a king who is physically sighted but morally blind, and by the end of Oedipus Colonus, we find a man who lacks sight, but has gained some moral insight. More importantly, we find in the character of Theseus a man whose moral insight exceeds that of Oedipus himself, and yet, whose moral sightedness and compassion depend on an encounter with this blind man, whose strangeness also opens up for Theseus his own previous encounter with strangeness and estrangement. This chapter examines two forms of vulnerability in these plays: vulnerability to ignorance, and vulnerability to the stranger. While in Oedipus Rex, Oedipus falls as a result of his ignorance of his own identity, in Colonus, Oedipus' status as a '̧́v́os leads to the protection and integration of political community.

We find in Oedipus an ambiguity: the question as to whether he is one who can 'see' or not. ${ }^{1}$ Oedipus has his physical sight, but lacks not only knowledge of his status as the polluted one, but also knowledge of the complexities of human life that might bring compassion to bear on a polluted man. Oedipus is harsh in his judgement of the

${ }^{1}$ Jennifer Ballengee, The Wound and the Witness: The Rhetoric of Torture (New York: SUNY Press, 2009), 45-8. 
mysterious polluted one, demanding that he not only be exiled from the community-by itself not a particularly harsh punishment-but also adding that the man be refused even the smallest cup of water by any of its citizens. Even Creon, who takes over the throne initially with reluctance, later exhibiting a capacity for inflexibility, cannot bear to banish Oedipus on the king's terms. At the same time, Oedipus has the counsel of a figure who is his inverse, the blind Teiresias, who lacks physical sight but can see, can know who Oedipus is, and what it will mean for the city-for Sophocles makes good use of the dual senses of oi $\delta \alpha$ as both 'I know' and 'I see'. Teiresias is more willing to see how things play themselves out, and not to hurry fate along by revealing Oedipus to himself. Only when Oedipus mocks Teiresias does Teiresias turn against him, and retreat from being his counsel right when Oedipus most needs good counsel. When Oedipus discovers that the polluted man is himself, when he is no longer blind to his own identity, he says, 'Light, may I now look at you for the last time. I have been brought to light as cursed in my birth, cursed in my wedlock, and in my killing' (1183-5). ${ }^{2}$ He thereby draws together his 'sight' of himself, to the sight of knowledge, and longing for the darkness. Oedipus longs for not only blindness, but also what it comes to signify for him: a longedfor ignorance of terrible acts that cannot be un-known.

Oedipus' predicament raises immediately for an audience member of Oedipus Rex the question of responsibility for wisdom, or its lack. The play raises a number of questions about knowledge, especially self-knowledge, and whether we can fully know even ourselves. For example, ought Oedipus to have realized that he was the true killer? Could he be expected to know that he would kill his own father and sleep with his own mother, given the long series of highly unusual circumstances that led to his being in that position? Knowing of the prophecy was not enough to prevent its occurrence; had he been ignorant, we suspect that would not have aided him, either. Knowledge of his destiny could not change it. If this is the case, Sophocles' audience might ask whether there is any locus of control for Oedipus, or whether he is merely in the hands of an unyielding fate, to which the only possible answer is reluctant acceptance.

To put it into a more traditional philosophical vocabulary, Sophocles raises for his audience questions surrounding the notion of moral

2 The translations throughout this chapter are my own except as noted.

This is an open access version of the publication distributed under the terms of the Creative Commons AttributionNonCommercial-NoDerivs licence (http://creativecommons.org/licenses/by-nc-nd/3.0/), which permits non-commercial reproduction and distribution of the work, in any medium, provided the original work is not altered or transformed in any way, and that the work is properly cited. For commercial re-use, please contact academic.permissions@oup.com 
responsibility in the light of a person choosing without knowledge of his action's context or its consequences. Knox has argued that Oedipus is not only free, but also responsible for his actions, for strictly speaking, the gods and Fate do not force his individual choices. Oedipus freely chooses to kill Laius, although he does not know his identity. Oedipus marries and begets children with Jocasta, not as a result of any specific external force, but as a result of his own internally driven actions. Knox writes of Oedipus, 'The autonomy of his actions is emphasized by the series of attempts made by others to stop the investigation... The hero is not only free but fully responsible for the events which constitute the plot. ${ }^{3}$ In one sense, Knox is correct that Oedipus is free in that the source of his action is internal. However, the play's supreme dramatic tension arises from a figure who somehow both acts freely and yet, in such ignorance that he seems incapable of genuine freedom. Moreover, his ignorance itself seems not to be culpable, as it was unavoidable, despite his best efforts to gain it. The audience, then, must ask even deeper questions about the constitutive nature of freedom, questions that his audience must engage in if they are to make sense of the narrative of Oedipus' life.

The play raises not only the question of individual moral responsibility in the light of ignorance, but, as importantly, the effect of our vulnerability to ignorance upon the wider community. Oedipus Rex begins with the city suffering a plague on account of its king's still unknown transgressions. By the end of the play, Oedipus is insistent with Creon that he must leave Thebes, and equally concerned that his daughters, especially, will suffer a curse as a result of his actions (1493-6; 1517). Thus, the audience is also encouraged to consider how and whether vulnerability to ignorance affects the larger political community as well. At moments, Sophocles points toward the possibility of despair as one response to vulnerability. For example, the Chorus in Oedipus at Colonus even declares, 'Not to be born is best of all: when life there is, second best is to go hence where you came, with the best speed you may' (1410-13). However, Colonus ultimately offers a quite different set of answers about encountering human vulnerability through the notion of hospitality to the stranger.

This chapter argues that among Oedipus' failings in Oedipus Rex is an inability to accept vulnerability and weakness both in himself and

3 B. M. W. Knox, Oedipus at Thebes: Sophocles' Tragic Hero and his Time (New Haven: Yale University Press, 1957), 12. 
others. I then suggest that in Oedipus at Colonus, Sophocles provides an alternative narrative as to how such vulnerability might be received, in the form of compassionate hospitality to the stranger. Theseus is the true hero of Colonus, insofar as he provides both a personal and political solution to the problem of Oedipus' vulnerability that Oedipus alone could not overcome.

There are several places in the text where Sophocles points to the possibility of a different response on Oedipus' part to his own transgressions. First, prior to his knowledge of the identity of the offender as himself, Oedipus makes the mistake of identifying punishment of the polluted person with his own 'advantage'. He says:

With justice you will see me an ally in battle ( $\left.\sigma^{\prime} \mu \mu \alpha \chi o v\right)$ in seeking to avenge this land, and god at the same time. Not for some far off friend's advantage, but for my own interest I will dispel this pollution. Whoever killed that one, might also wish to kill me with his fierce hand. So helping him, I help myself. (135-41)

We can easily see the deep irony of the passage-for Oedipus will wish to use his own hand against himself later in the play, but can hardly be said to be acting in his own interest in pursuing the heretofore unknown murderer. Oedipus' failing is that he believes too easily in his own righteousness, as defender of the city and of god's laws. He assumes that the city's interest and his noble intentions will always line up. And he lacks a sense of compassion for the unknown criminal, assuming an absolute opposition between city and criminal, a polarity between the communal justice and the injustice of the murderer, absolute opposition between himself as the just king and the polluted one as an unjust man. The tragedy's audience can see that the polarity is not so simple: Oedipus is the polluted one, but he also is truly the one who loves and cares for his city's well-being. As Segal notes, Oedipus' kingship opens up a liminal realm, in which oppositions between nature and culture, inner and outer, city and wild are no longer clear. ${ }^{4}$

\footnotetext{
${ }^{4}$ Charles Segal, Tragedy and Civilization: An Interpretation of Sophocles (Norman, Okla.: University of Oklahoma Press, 1999), 47.
} 
Oedipus himself is unaware of the ambiguities inherent in his kingship and his humanity. His mistake is to believe in absolute oppositions between the just and unjust when a more nuanced answer is possible. On this reading, Oedipus thinks of justice and injustice as morally absolute categories in a world in which such categories do not always apply neatly.

A second failing might be found in Oedipus' harshness with the one that has killed the king, for his vows to exclude the man entirely from society are extreme. He declares that the polluted one may not reside in his land; is not to be welcomed by any in the land, not even greeted by its citizens; excluded from worship and even excluded from the hospitality of water to wash his hands (236-42). Exile alone was an appropriate ritual response to pollution, but Oedipus lays these additional conditions of refusing water or even a simple greeting to the polluted man. If Oedipus had imagined himself as the criminal, would he not have considered the possibility that such additional demands are beyond the requirements of purification? After all, Oedipus is not simply $\beta \alpha \sigma \iota \lambda \epsilon v_{s}$ (king) but $\tau \dot{v} \rho \rho \alpha \nu o s$ (tyrant), a man who has acquired his rule by coming into the city from the outside. ${ }^{5}$ Oedipus fails in his exclusion of the morally weak, and especially fails to understand that he is capable of such weakness himself.

A third instance of inattentiveness to vulnerability is when he treats Teiresias so harshly. In his understandable desire to escape the truth of the blind man's prophecy, Oedipus searches for alternative explanations for why Teiresias declares him to be the criminal. He mocks the blind Teiresias, calling him a 'deceitful bogus priest who has eyes for gain, but is blind in his art' (388-9). Oedipus' anger reaches a fever pitch, and is not easily extinguished. ${ }^{6}$ Indeed, his rage seems to stem from a sense of overconfidence in his own knowledge, in contrast to that of others. For example, Oedipus is dismissive of Teiresias' ability to know the truth about his identity; he reminds Teiresias of his clever defeat of the Sphinx with the sarcastic proclamation that the one who solved the puzzle was 'I, unknowing Oedipus' ( $\dot{o} \mu \eta \delta \dot{\epsilon} v \epsilon i \delta \omega$ s Oidímovs) (396). ${ }^{7} \mathrm{He}$ is angry not only at the particulars of Teiresias'

\footnotetext{
${ }^{5}$ Knox details the use of $\tau \dot{v} \rho \rho a \nu o s$ instead of $\beta a \sigma \iota \lambda \epsilon v_{S}$, and notes the irony that Oedipus also would have been legitimate $\beta a \sigma \iota \lambda \epsilon v_{S}$ on account of his father Laius. See Knox, Oedipus at Thebes, chapter 2.

${ }^{6}$ Knox, Oedipus at Thebes, 27-8. $\quad{ }^{7}$ Knox, Oedipus at Thebes, 127.
} 
ideas, but also at the idea that someone else might know something that he does not, and could not, know about himself. One wonders whether Teiresias might have suggested an alternative response to the problem of pollution, less severe, if only Oedipus had not unleashed his rage on the seer.

Creon also suggests 'obstinacy' on Oedipus' part when the king assumes a plot on Creon's part (549), and refuses to listen to his entreaties that he is innocent. He says that this obstinacy forms no part of wisdom, and is part of Oedipus' limit as a king. Jocasta is slightly gentler in her assessment, judging Oedipus to have excessive $\theta v \mu$ ós when speakers come with bad news (914). She says, he is 'under the speaker's control, when he speaks of fearful things' (917-18). We see this excitability in Oedipus in the account of how he murdered Laius, out of rage for being pushed off the road. Oedipus lacks the moral virtue of temperance, to be sure, but along with that lack of moderation is a lack of consideration of the ordinary imperfections that accompany being human.

We see in each of these instances a common theme: Oedipus possesses an overly confident sense of his own righteousness, a judgement of the would-be criminal as his polar opposite, a tendency to suspect or to blame others, rather than to look inwardly. He assumes an absolute division between those who are just and unjust, those who care for the city and who bring it harm, those who possess virtue and who lack it. Thus, when he discovers that he himself is the source of injustice, his own response is to be harsh with himself and not even to consider a mode in which such injustice could be remedied without expulsion from the city. The pollution brought on by murder of his father and incest with his mother indeed warranted a strong response. But Oedipus is unable to incorporate a response that can maintain and preserve the body politic, while Sophocles in Colonus will later display its possibility in Theseus. Oedipus is unable to imagine the possibility of his own moral vulnerability, with the eventual result that his vulnerability becomes displayed in the form of a physical wound, in his literal blindness, which expresses the inescapability of his vulnerability.

Parker's book on pollution explores the concept in depth in the context of early Greek religion. ${ }^{8}$ Two distinct terms connote pollution:

\footnotetext{
${ }^{8}$ Robert Parker, Miasma: Pollution and Purification in Early Greek Religion (Oxford: Oxford University Press, 2003).
} 
$\mu \prime \alpha \sigma \mu \alpha$ and ${ }^{\prime} \gamma o s$. While $\mu \dot{\prime} \alpha \sigma \mu \alpha$ is the idea of something being polluted in the sense of contaminated, the term áyos also means more specifically something directed against the gods and their rules-not only contaminated, but also 'unholy'. To use Parker's example, a corpse gives off $\mu i \alpha \sigma \mu \alpha$, but an unburied one creates äyos, an offence against the gods themselves. ${ }^{9}$ Most instances of pollution in the Greek sensibility are connected either to birth or to death. In the case of Oedipus, his pollution is an unnatural mixture of both: he's killed his father, the source of his life, and produced children in the same womb which had borne him. For most natural pollutions (the time right after birth and time after contact with the dead), the only real consequence was to be barred from entering a temple, in part to emphasize the gulf between the gods, who do not die, and men, who do.

Parker argues that, while the incestuous relationship was seen as polluting, alternatives other than permanent exile from homeland also existed. He writes, 'The incestuous could be socially isolated without exile, by exclusion from sacrificial communities and religious exchanges. ${ }^{10}$ Although incest is an extreme case of pollution, even here the pollution is not irreversible. For many forms of sexual pollution, Robinson argues (such as male prostitution or adultery), a period of sexual abstinence was sufficient to return the person to a state of purity sufficient for religious participation. ${ }^{11}$ Murder-pollution, however, was regarded as a terrible violation of the moral order, and parricide more so than any other form of murder-pollution. ${ }^{12}$ Expulsion for parricide, even involuntary parricide, expresses the social evaluation that such a killing is deeply unnatural, and even more fearful when it is unknown, as in Oedipus' case. That Oedipus could kill his father without even realizing it, even after taking such careful steps to prevent its prophesied occurrence, is itself an upsetting of the natural order. Arguably, for many Ancient Greeks, the concept that one could accidentally kill one's father, in ignorance, is even more upsetting than the idea of choosing to do so. So, questions of freedom of will are not as significant as the question of whether the 'natural' has been overturned, with regard to 'pollution'. ${ }^{13}$ For it is not

\footnotetext{
9 Parker, Miasma, 8.

10 Parker, Miasma, 98.

11 Parker, Miasma, 97.

12 Parker, Miasma, 124-5.

13 Parker, Miasma, especially 133ff., where Parker develops the concept of natural
} pollution. 
a moral evaluation of Oedipus and his choices that counts, but rather the overturning of basic principles of life and death that leads to pollution. Thus, nature itself is upset at King Laius' death, such that at the beginning of the tragedy we find that women cannot give birth except to stillborn children, crops will not grow, and all generation has ceased.

As king, then, Oedipus was required to act against the polluted man in some way, given the extreme reaction of the natural world. As a ruler, his work was to protect his city, and upon learning of the pollution, the most obvious course of action is, of course, to expel the polluted man from the kingdom. Indeed, qua king, his best interest is the city's best interest; but part of the tragedy here is that Oedipus the king's interest is contrary to Oedipus the man's interest. When Oedipus discovers that he himself is the polluted man, his reaction is not denial of punishment, but rather to proclaim his sorrow that his future will be so dismal.

Indeed, the point of the tragedy is to set forth Oedipus as a paradigm of reversal in human life. The language of reversal figures throughout Oedipus Rex. The play opens with Oedipus greeting suppliants, but ends with his becoming a wandering suppliant himself. Oedipus begins as a sighted man who cannot see the truth of his own state, and ends as a blinded man who knows it. We hear the herdsman speak of his 'pity' for the Oedipus who was to die as an exposed infant, who then realizes that this pity had only 'saved him

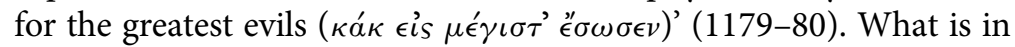
darkness, comes to light, and what had seemed to be light, becomes only darkness (see e.g. 1183).

We find even a reversal of meaning of many of Oedipus' lines earlier in the play, before he recognizes his identity as the polluted man. For example, when the suppliants approach him with their

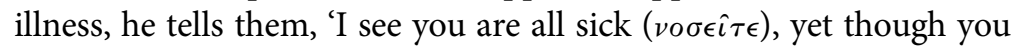

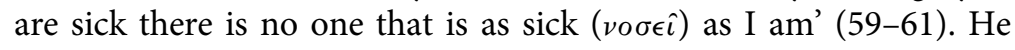
declares himself to be 'one that is stranger ( $\left.\dot{\alpha} \gamma \dot{\omega} \xi \xi \xi^{\prime} v o s\right)$ to the story

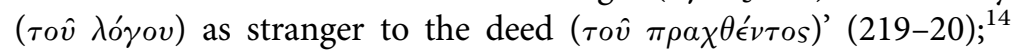
while he intended that he was no part of this deed, we might emphasize that his own life story, though he has lived it, has so far been

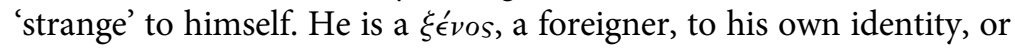

14 Translation of this line from David Grene (translator and editor), Sophocles I, 2nd edn. (Chicago: University of Chicago Press 1991). 
to use an English term that connotes this well, he is unknowingly 'estranged' from himself. In fact, as the Greek lays out the word order,

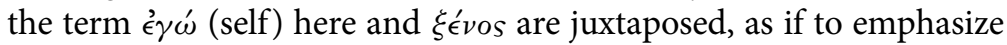
that he is a stranger to himself. Oedipus speaks many words that contain truths that he cannot yet understand, but whose truth will later be revealed in a new way; he is an unwitting ironist. ${ }^{15}$ As Aristotle long ago commented, Oedipus exemplifies the essence of the tragic plot most perfectly since, in his case, recognition and reversal coincide (Poetics 1452a30).

Another dimension of reversal has to do with the normal experience of understanding wisdom or seeing the truth as a joyful experience, one that satisfies our desire to understand, a natural fit between what we want and the world itself. That is, not only on a philosophical understanding of the world, but also an ordinary one, we see ourselves as human beings in a world where there is some kind of a natural fit between ourselves as knowers, and the world as knowable. Such a stance is not merely descriptive for us. It is not only a fact that we can know. The stance of seeking to know is also an emotional way of being in the world, in which we find excitement, joy, surprise, and a wide range of feeling in making such discoveries. Our natural sense of discovery is one of joy and pleasure in the 'fit' between seeking to know, and knowing, being completed. Despite Oedipus' characteristic valuation of knowledge, as in his solution to the riddle of the Sphinx, now Oedipus experiences the opposite. ${ }^{16}$

As we see from the language that Teiresias uses, this is not the case with Oedipus: 'he'll have no joy $(\dot{\eta} \sigma \theta \dot{\eta} \sigma \epsilon \tau \alpha \iota)$ in the discovery

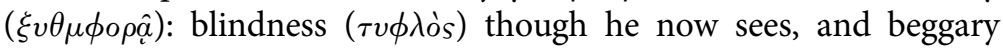
though he is now wealthy' (453-5). As the truth begins to 'come together' for Oedipus (a more literal translation of $\xi v \theta \mu \phi o \rho \hat{\alpha}$ ), he experiences pain and not pleasure. Teiresias, though a prophet invested in revelations of divine wisdom, proclaims wisdom to be a terrible thing at times: 'Alas, how terrible is wisdom ( $\phi \rho \nu \nu \in \hat{\imath} \nu)$ when it

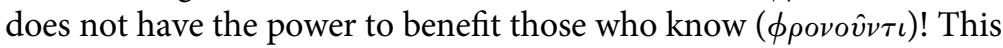
I knew but forgot ( $\left.\epsilon i \delta \dot{\omega} s \delta \iota^{\prime} \omega \lambda_{\epsilon} s^{\prime}\right)$, or I would not have come' (316-18). Here $\phi \rho o v \in \hat{\imath} v$, to think, to know, is seen as a terrible ( $\delta \in \hat{\imath} \nu \circ s)$ thing.

15 Paul Hammond, The Strangeness of Tragedy (Oxford: Oxford University Press, 2009), 76-7.

${ }^{16}$ Knox notes Oedipus' care for not only knowledge in general, but also clarity and fullness of truth. See Knox, Oedipus at Thebes, 18. 
Teiresias' term for knowledge, $\epsilon i \delta \omega^{\prime}$ (the perfect participle of oi $\delta a$, to know), literally means to 'see' something. Teiresias the blind prophet can 'see' what Oedipus cannot. But while he cherishes the truth, he also sees no value in offering words that can only bring pain, even if they are true (356). To know lacks value, but also to forget has had destructive value, as the Greek link between forgetting and destruction

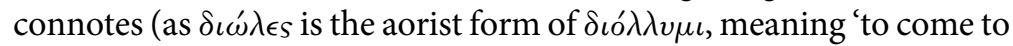
ruin'). ${ }^{17}$ We have in Oedipus a reversal of the epistemological order, where the discovery of new knowledge becomes an evil and leads to misery instead of joy.

While Oedipus is one driven to know, at all costs, Jocasta briefly offers a dramatically different alternative to the human desire to know. She asks, 'What should man fear since chance ( $\tau \dot{v} \chi \eta s)$ rules, and he can foreknow ( $\pi \rho$ óvoıa) nothing with clarity? The best life is to

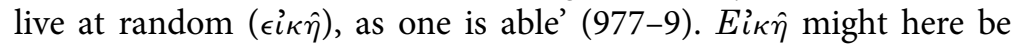
translated as 'randomly' or even 'without a plan or purpose'. Jocasta's emphasis on chance as central to human existence emphasizes a certain impossibility of understanding that informs her own preference not to reach too deeply into matters, preferring to skim the surface of things, rather than to discover dark truths that lie beneath. However, such lightness does not save Jocasta either, who ends her life in her own horror at discovering her incestuous marriage; neither would the perpetual hiddenness of the truth have saved the city and its suppliants from the effects of pollution. So, while Sophocles briefly raises the possibility of not-seeking-to-know as an alternative to miserable truths, this path is also not reasonably open to human beings.

The Chorus presents a tragic sensibility in its declaration of Oedipus as a 'paradigm' of human existence: 'Generations of mortals $(\beta \rho o \tau \hat{\omega} \nu)$, I reckon your life as but a shadow. Where, where is the

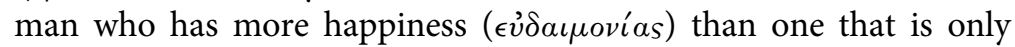
seeming $(\delta о \kappa \epsilon \hat{\imath} \nu)$ and even then seemingly falls away? Oedipus, you are my pattern $\left(\pi \alpha \rho \alpha ́ \delta \epsilon \iota \gamma \mu^{\prime}\right)$ of this, enduring Oedipus, you and your fate' (1187-95). Oedipus is a paradigm, literally a model of what it means to

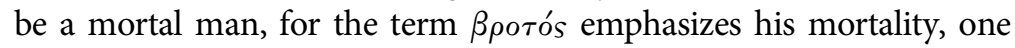
who will die. Oedipus is a model—or the term $\pi \alpha \rho \alpha ́ \delta \epsilon \iota \gamma \mu \alpha$ can also be

17 This language of destruction runs thematically through descriptions of Oedipus. For example, the Theban shepherd's report of Jocasta's decision to have her son killed so that the prophecy might go unfulfilled uses a $\nu^{\prime} \alpha \lambda i^{\prime} \sigma \kappa \omega$, 'destroy', rather than weaker words connoting infant exposure. See Ballengee, Wound and the Witness, 47. 
used as 'example'-of what it means to be mortal, that is, to be ignorant of even the most basic knowledge of ourselves. ${ }^{18}$

While Oedipus sought knowledge at all costs, and Jocasta to avoid it, Creon initially presents an alternative path. When he encounters the blinded, distraught Oedipus, Creon insists on taking him into the house, out of his connection to him as a kinsman (1430-1). While Oedipus is certain that the god demands that he leave the city, Creon suggests that they take the time to find out what they really should do: 'This was said. But nonetheless, given the present need, it is better to learn $(\epsilon \kappa \mu \alpha \theta \epsilon \hat{\nu})$ fully about what to do' (1442-3). Creon wishes, no doubt, to discover what the oracle wants them to do. However, his words to Oedipus about his care for his children also display compassion for Oedipus' need on Creon's part. While so many others in the play react in horror to Oedipus' actions and his blinded, selfwounded appearance, at first Creon is a paradigm of compassion and caution. He asks that Oedipus remain a while, and brings his children to him. He neither insists on Oedipus' harshness, nor does he advocate the view that it is better not to know, as Jocasta had. Oedipus thinks Creon is experiencing pity when he brings him his children, but if we look with care at Creon's words, we find something subtly, but significantly different: 'You are right. I brought this about, know-

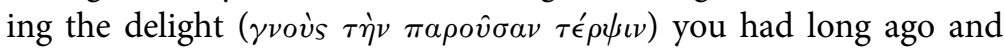
now have' (1476-7).

Creon brings Oedipus his children out of knowledge for his love of them. For Creon, this knowledge ( $\gamma \nu \hat{\omega} \sigma \iota s)$ of love (literally, delight or joy, $\tau \epsilon^{\prime} \rho \psi \iota \varsigma$ ) is more significant a form of wisdom than the others we have encountered so far. In fact, we might say that this form of wisdom as a kind of 'recognition'-as the term $\gamma \nu \hat{\omega} \sigma \iota s$ connotes-to recognize, to see who someone is, Sophocles raises as an important kind of knowing. Creon's brotherly love for Oedipus informs how he sees him, how he understands him, and how he reacts to him. What he sees in Oedipus is not primarily the polluted man, nor a dispossessed king, but a man who is capable of fatherly love. Creon looks at the children not primarily as children of incest, but instead as the father's beloved ones, the few remaining beings that can still give him enjoyment. Creon thus momentarily provides the tragedy's audience with an alternative vision of wisdom in moments of vulnerability as

18 Ballengee, Wound and the Witness, 48.

This is an open access version of the publication distributed under the terms of the Creative Commons AttributionNonCommercial-NoDerivs licence (http://creativecommons.org/licenses/by-nc-nd/3.0/), which permits non-commercial reproduction and distribution of the work, in any medium, provided the original work is not altered or transformed in any way, and that the work is properly cited. For commercial re-use, please contact academic.permissions@oup.com 
linked to recognition of the concrete reality of another human being. While commentators such as Knox propose that the play asserts a 'religious view of a divinely ordered universe', ${ }^{19}$ the multiple perspectives set out by various characters on the nature of suffering suggest otherwise. Sophocles engages with the mystery of the question of suffering. Instead of providing a single, clear intellectual solution to the problems raised by freedom and fate, Sophocles presents multiple answers to the question as to the appropriate human response to suffering. His play raises for his audience the possibility of reflection on fate and freedom, suffering and freedom from it, not only during the play, but also after its performance. Here, Creon exhibits the possibility of a wisdom informed by gentleness, compassion, and identification with human weakness, instead of Oedipus' harsh selfjudgement, or Jocasta's wilful ignorance.

This theme of familial gentleness and compassion is central to Oedipus at Colonus, where we see Antigone's great devotion to her blind father. While her two brothers have abandoned Oedipus in his need, Antigone has accompanied her father in his wanderings, as his seeing eyes, and at considerable personal risk to herself. Oedipus says that she acts with the bravery more associated with men than with women, while his sons have done little for him. There is sweetness between Antigone and Oedipus, a care she exerts for him in his vulnerability and blindness, which tempers many of the harsh sufferings of the plays' action. While the two plays were not performed together, and do not constitute a cycle in the way that Aeschylus' Oresteia does, it is nonetheless telling to consider how differently Sophocles treats the same characters and a related storyline in two plays staged many years apart. In particular, we find in Oedipus at Colonus that Sophocles displays a considerable amount of sensitivity toward the cursed Oedipus, and links hospitality to the vulnerable to the political good of Athens. While Oedipus Rex considers pollution and the difficulties with finding a reasonable political response to

\footnotetext{
19 Ballengee, Wound and the Witness, 47.
} 
pollution, Oedipus at Colonus emphasizes the value to be found in reception of the wounded stranger by the city or its leaders.

At the outset of Oedipus at Colonus, Oedipus expresses that he has learned something from his suffering, especially 'to endure' (8). He takes comfort in the prophecy that at his life's end, he finally will find a place to rest, that he will be a 'ruin (a' $\alpha \eta \nu)$ ' for those who drove him away, but 'profit $(\kappa \epsilon ́ \rho \delta \eta)$ ' for those who receive him (92-3). Oedipus sees the possibility of a meaningful end, a meaningful response to his vulnerable moral and physical condition, as displayed in the downfall of those who harmed him, and the uplifting of those who received him. We might understand these earlier words to be fulfilled in the blessings placed upon Theseus, who receives him with hospitality and compassion, despite knowledge of his pollution. While in life his kingship did not bring good to Thebes for the long term, in death, his presence will bring protection to Athens. Oedipus is no longer king, but nonetheless, plays a political and spiritual role in his presence at Athens.

Moreover, Oedipus' model for knowledge is no longer that of sight, but touch. While the Oedipus Rex is dominated by images of knowledge as sight, in Oedipus at Colonus, we see a man whose main entry into the world of sensation comes through hearing and through his daughter Antigone's touch, as she leads him from place to place in his exile. Oedipus is reliant on others who speak to him, and remarks, 'I see by the sound of a voice ( $\phi \omega \nu \hat{\eta} \gamma \dot{\alpha} \rho$ o $\rho \hat{\omega})$, as the saying goes' (139). Here, his hearing makes him dependent on others, insofar as they choose whether to reveal themselves and the world to him. Antigone willingly describes to Oedipus his surroundings and the events that unfold around him (e.g. 17-22). Similarly, he depends on Antigone to offer her lead of hand to him; there is tenderness and a revealed dependency when he asks, 'Give me your hand,' and Antigone reassuringly replies, 'Here I place it in yours' (176-7). Such a response stands in contrast to Oedipus' distraught question in Oedipus Rex, 'Do you think my children, born as they were, could look sweet to my eyes?'

As Long has argued, the use of the model of touch, rather than sight, changes the way in which Oedipus relates to the objects of his knowledge. $^{20}$ In the case of sight, the person being seen can be

${ }^{20}$ Christopher Long, 'A Father's Touch, a Daughter's Voice: Antigone, Oedipus and Ismene at Colonus', presented at the 2010 Sophocles Colloquium, University of Utah, November 2009. 
objectified. The seeing subject can see his object, apart from being seen in return, and can be at a distance from that object, protected by his own distance. In the case of touch, however, the contact with the object of perception is immediate. Here, in the instance of human touch, the contact between subject and object is also mutual. The one who touches, in being led by hand on his journey, is also the one who is being touched and felt as a presence by another. In the dependence of touch for Oedipus to know and to navigate his world, Oedipus experiences a certain kind of vulnerability in his very mode of knowledge, for he cannot know without also being known. This vulnerability seems to have brought him closer to both of his daughters, in his dependence on Antigone and gentleness with her. He expresses his need for Ismene's touch, also, when she arrives at Thebes, both to confirm her presence and also to express

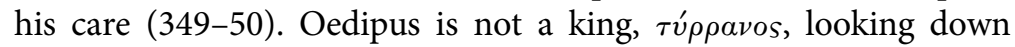
from his throne at the suppliants, but instead, led by his daughter's hand, touched by Antigone in her care and support of him as the suppliant and exile.

However, the Oedipus of Colonus is an angry man, despite what his initial words about learning endurance might seem to indicate. While Oedipus seeks pity for himself and his polluted state, he shows little compassion for what might have led his sons to pursue lives apart from accompanying him in his wanderings. His focus on whether they are living 'good' lives centres entirely around whether their devotion to their father has been sufficient. There is more than a little irony in Oedipus' judgement of his sons; after all, his parricide would seem to exceed their negligence of him in degree of moral failure. Similarly, Oedipus continues to be angry about Creon's treatment of him, in forcing him to go into exile.

Oedipus seeks to differentiate his parricide and incestuous marriage from Creon's actions through focusing on his own relative lack

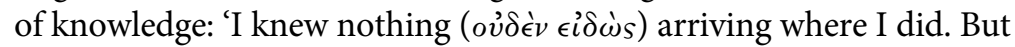
those on account of whom I suffered, they with knowledge ( $\epsilon i \delta o ́ \tau \omega \nu)$ destroyed me' (273-4). This judgement makes the clarity of knowing or not knowing, possessing responsibility for one's actions, and not possessing it, too clean cut, however. The Creon of Oedipus Rex, as much as anyone, was puzzled by how to respond to Oedipus' pollution, for he did understand that it was not by any informed choice that Oedipus acted in ways that were polluting; and yet, his pollution did upset the natural order and the gods such that the only viable 
solution seemed to be to expel him from the city. And yet, Creon waited to follow through even on Oedipus' command to banish him, seemingly waiting for an alternative possibility to present itself. Creon cannot be said to have possessed full knowledge of the best way in which to rule the city after these unusual events. While Creon's motives in Oedipus at Colonus are unclear, they are not entirely unreasonable, given what audiences may recall of Oedipus Rex.

Aristotle's categories of moral responsibility in the Nicomachean Ethics are helpful here (N. Ethics III. 1). While not a fully developed theory of responsibility, Oedipus' comments about his own ignorance point in a general way to the kinds of considerations Aristotle later raises about the role of knowledge of particulars in moral accountability. While Aristotle includes under the designation 'voluntary' a whole range of actions undertaken by a moral actor, he offers notable exceptions to ordinarily voluntary actions if certain circumstances are present. The term 'involuntary' applies to actions in which the moral actor was ignorant of particulars. For example, if a man believed that a weapon that he threw was harmless and meant for practice exercises, but turned out to be a real weapon, and so injured his victim unintentionally, this lack of knowledge is a mitigating factor. Importantly, Aristotle sees the presence of regret afterwards as central to this moral evaluation of an action as 'involuntary'; the moral actor must be regretful and must wish that the event had not occurred. Such a combination of ignorance of particulars and regret is clearly present in Oedipus' polluting crimes. He lacked knowledge of his father as his father, of his mother as his mother, and so did not know the particulars of his moral action. Moreover, he felt not only regret, but anguish at the patricide and the incest. On an Aristotelian model, Oedipus ought not be seen as morally culpable for parricide or incest.

Creon, Polyneices, and Eteocles seem to have had full knowledge of the particulars of their actions with Oedipus, and little regret for their moral choices, and so cannot be said to act in an involuntary way. Oedipus says of Eteocles and Polyneices that when they had the power to bring help, they chose not to help him (427-45). They lacked neither the means to assist him in his wanderings, nor the knowledge of his state or his identity as their father. Oedipus sees them as wholly responsible for their neglect of him, in a way that he is 
not responsible for his more extreme acts against his own parents, chosen entirely in ignorance. ${ }^{21}$

However, we can imagine many other motivations that might have led Polyneices and Eteocles to choose lives that did not include devoting all their energy to their father's care. To begin, these sons seemed not to define themselves in terms of an identity as products of their parents' incest. That is, rather than choosing exile along with their father, who understood himself to be polluted, they refused to see themselves as polluted along with him. Indeed, prior to Oedipus' curse against them, there is no reason to believe that Oedipus' children were polluted, or needed to flee the city. In Oedipus Rex, Oedipus worries about his daughters' ability to marry, as they may seem to others to be cursed (1500), but we have no independent evidence in the plays that this is true, and Oedipus expresses no such worries about his sons. In the Antigone, Creon's main hesitation with his son's involvement with Antigone is her difficult temperament and wilful lawlessness; there is no mention of her being polluted as a reason not to marry her. Polyneices and Eteocles alike commit themselves to living the lives not of exiles, but of political men, as their station in life would have demanded. If their mistake is to seek to escape the wandering and exile to which their father is subjected, it is an understandable desire on their part.

Neither son is particularly virtuous, of course. Both brothers fight one another for the throne, instead of choosing the shared rule that Oedipus had with Creon in his better days. Indeed, Polyneices seems to have inherited his father's temper as well, when he refuses to leave behind his ambition to rule Thebes, insisting that he go to his own death and fight his brother in combat, even as Antigone asks why he must succumb to being made 'angry $(\theta v \mu o \hat{v} \sigma \theta \alpha \iota)$ again' (1420). Creon tells Oedipus that he is 'giving in to your temper ( $o \rho \gamma \hat{\eta})$, which always ruins you' when he refuses Creon's (deceitful) offer to return home and offer protection to Thebes (855). But Creon speaks to Oedipus not with care, but with threats of kidnapping his daughter, and violating Oedipus' freedom.

21 As Ahrensdorf notes, Oedipus here seems motivated by anger and not reason; he fails to recognize the contradiction in absolving himself of his unknowing parricide and yet, his desire for harsh punishment of his sons for their neglect of him. Peter Ahrensdorf, Greek Tragedy and Political Philosophy: Rationalism and Religion in Sophocles' Theban Plays (Cambridge: Cambridge University Press, 2009), 70. 
At numerous points, words are understood to be powerful, as either forces of good or evil. Many times, Oedipus treats words as though they were intrinsically dangerous, or hurtful, particularly if those words revealed his own weakness to others or even only to himself. At the beginning of Colonus, Oedipus prefers that his story remain silent, that he remain alone in his suffering with only his daughter. Oedipus speaks of the Chorus as uttering wounding words, when they speak aloud of his father's murder. When he says, 'A second time you strike me,

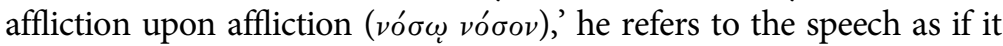
were itself a way to harm him (545). It is not only the memory of the patricide, or its revelation, but the words themselves that are blows to Oedipus, who prefers to keep his suffering silent and to endure. He is afraid to tell the truth about himself, and it is only Antigone's insistence that he must speak his truth, as difficult as it is, that frees Oedipus to confess his real identity, a confession that will eventually bring him freedom instead of continued exile (217). He is afraid of his story being

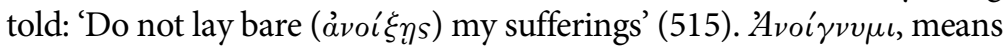
literally 'to open up', as Oedipus feels exposed in being known for his deeds. Words have the power to open up, to make vulnerable.

Oedipus himself chooses to wound his own sons with a curse upon them, a curse that will come to fruition not only with the deaths of Polyneices and Eteocles, but also the death of Antigone, whom Oedipus wishes to protect. His harmful words have repercussions far beyond what he anticipated. Antigone also speaks of the power of words: 'Words offer many things, bringing delight, or sometimes anger, or pity; they somehow give voice $(\phi \omega \nu \eta \dot{\eta})$ to what is voiceless

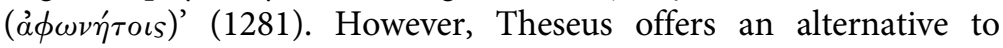
wounding words, words of reception and hospitality. While Oedipus is convinced that the truth of his life will be too shocking, or his history too revolting once told, Theseus receives his full story in compassion, even sharing a bit of his own story in return.

\section{III}

Theseus begins with the possibility that this $\xi^{\prime} \operatorname{vos}$ might teach him something:

Teach me ( $\delta i \delta \alpha \sigma \kappa \epsilon)$. You would need to tell me something terrible ( $\left.\delta \epsilon \iota \nu \eta^{\prime} \nu\right)$ to make me depart from you. For I know (o` $\delta \alpha)$ myself what it means to be 
raised in exile ( $\left.\xi \xi^{\prime} \nu 0 s\right)$, like you, and in foreign lands, I wrestled with many

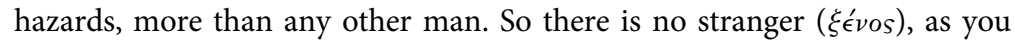
are now, from whom I would turn away or fail to help. For I know $\left(\epsilon^{\prime} \xi o r \delta^{\prime}\right)$ I am only a man $(\dot{\alpha} v \dot{\eta} \rho)$, whose fulfillment of tomorrow is no greater than is yours. (561-9)

Theseus not only reassures Oedipus that he is not as $\delta \epsilon \iota v o ́ s$, as terrible, as he fears; he also suggests that the polluted man has something to teach him. Theseus grounds his understanding of Oedipus in his own experience of being a $\xi \epsilon^{\prime} v o s$, a foreigner, one who is excluded from others, but also as a person who has understood his primary identity as the same as that of Oedipus, insofar as they are both simply men. Theseus incorporates Oedipus' vulnerability in which his wounds are constitutive of his humanity, and not a mark of his necessary exclusion from society.

When Theseus goes to rescue Ismene and Antigone from their uncle, he tells his army to go to a crossroads in order to bring them home (901). We might remember that the murder of Oedipus' father also took place at a crossroads. This 'second crossroads' at which Theseus' men act is representative of a turning in Oedipus' fate. While the first crossroads was the site of his pollution, this second crossroads becomes the locus of his own acceptance. In listening to and receiving Oedipus' story, a story that heretofore has only caused him shame, Theseus allows Oedipus to participate in a kind of selfobservation of himself from the perspective of others. While Oedipus has already learned some compassion for himself in the years since his exile from Thebes, this compassion and a kind of peace arise when he can see himself through Theseus' eyes. His blindness, he learns, is not only the metaphorical blindness he had of his own identity in the murder and incest and his literal, self-inflicted blindness. Oedipus has also been blind to the possibility of full reconciliation and acceptance into the community. But in the background of Colonus is also the theme of the Eumenides, Aeschylus' gentled Furies who now kindly protect Athens instead of pursuing the polluted. ${ }^{22}$ Theseus, too, will act as a gentle spirit to Oedipus.

Theseus not only accepts Oedipus' story, and welcomes him in the fullness of his reality, but also explains in this passage the motivation

${ }^{22}$ Henry Walker, Theseus and Athens (Oxford: Oxford University Press, 1995), 176.

This is an open access version of the publication distributed under the terms of the Creative Commons AttributionNonCommercial-NoDerivs licence (http://creativecommons.org/licenses/by-nc-nd/3.0/), which permits non-commercial reproduction and distribution of the work, in any medium, provided the original work is not altered or transformed in any way, and that the work is properly cited. For commercial re-use, please contact academic.permissions@oup.com 
for his deep compassion. ${ }^{23}$ Theseus is a man who is well aware of his own vulnerability, and so can identify with others with whom he shares this vulnerability. Indeed, such self-awareness seems to inform his courage and sensible judgement in how he responds to Oedipus, in stark contrast to Creon's relative impulsiveness. Theseus understands the experience of being in exile, and the longing for 'home'. As if to emphasize Theseus' compassion, Sophocles' account of Theseus' story makes no allusion to earlier myths about Theseus that are less than hospitable, for example, his kidnapping of Helen, abandonment of Ariadne, or attempted kidnapping of Persephone. ${ }^{24}$ Instead, Sophocles' presentation of Theseus is of a king who recalls his own

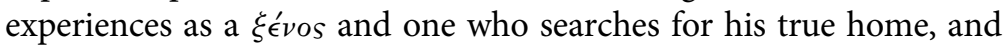
so understands what is 'strange' in others. As Mills phrases it, the Athenian version of Theseus is 'purged of anything alien to the ideal Athens'. ${ }^{25}$

The term $\xi^{\prime} \operatorname{cv}^{\prime}$ os has multiple layers of meaning within these two plays. It can mean simply 'stranger', the one who is not Greek, or not of this particular city, the outsider to whomever 'we' are. As Kristeva emphasizes, the stranger allows a community to define itself and even to grant it a false sense of its own security by assuring itself that while the Other is outside, we are not the other, we are on the inside. ${ }^{26}$ The Outsider's presence reminds us of the possibility that we could be outside, and yet, reassures us that, for the moment, we are not him, we are on the inside, we who belong to whatever community the stranger does not belong to. The paradox of Oedipus is that he has been both the leader and the outsider to his own community. The one who saves and leads Thebes, who indeed embodies the unity of the community, is the one who turns out to be responsible for its pollution. And the same king who not only belongs to the political community, but who

${ }^{23}$ Blundell notes that Theseus may have multiple motives including 'sympathy, piety, loyalty, self-interest, and the interests of his city'. Here I focus on Theseus' sympathy in order to highlight the centrality of the acknowledgement of vulnerability in virtue, but of course do not exclude additional motives. See Mary Whitlock Blundell, Helping Friends and Harming Enemies: A Study in Sophocles and Greek Ethics (Cambridge: Cambridge University Press, 1989), 231.

${ }^{24}$ For an excellent summary of pre-tragic myths surrounding Theseus, see Walker, Theseus and Athens, chapter 1 and Sophie Mills, Theseus, Tragedy, and the Athenian Empire (Oxford: Oxford University Press, 1997), chapter 1.

${ }_{25}$ Mills, Theseus, Tragedy, 69.

${ }^{26}$ Julia Kristeva, Strangers to Ourselves, trans. Leon S. Roudiez (New York: Columbia University Press, 1991), chapter 2. 
possesses the power to determine who is in and who is out, who is a member and who will not belong, turns out to be an outsider. Oedipus is a kind of 'hidden stranger', hidden both from others and from himself in his status as the 'polluted one' who has committed incest and who brings sickness on the city. He is a paradigm for the idea that the safety and security of belonging to an 'inner circle' is often false, or at least temporary. Oedipus at Colonus was written around the time of the reign of the Thirty Tyrants and the overthrow of the democracy (404 BCE), and staged in 401 BCE after the democracy's restoration. ${ }^{27}$ The question as to who belongs to the city, who is excluded, and who is in political and social exile was a living reality for many Athenians.

But the meaning of $\xi \epsilon^{\prime} v o s$ here goes even deeper, for the term $\xi^{\prime} \epsilon^{\prime}$ os can also mean a person in a formalized $\xi \in v^{\prime} \alpha$, or guest-host relationship, as this sense increasingly becomes important in Oedipus' relationship with Theseus. ${ }^{28}$ The stranger and the foreigner is not only one who reminds us of our own coherence as a community, but is also a constant reminder of the real possibility of our own estrangement and our own exile. Zeus, the most powerful of the gods, is sometimes called Zeus Xenios, god of the stranger; and we see in works such as Homer's Odyssey the moral imperative to care for the stranger, the beggar, the outsider who may be a god in disguise. Therefore, the host must treat the guest as almost divine, even without knowing who he is. And if there is a mutual exchange of gifts between host and $\xi^{\prime} \cos$, then the obligation of mutual care occurs. After a relationship of $\xi \epsilon v i^{\prime} a$ has been formalized by an exchange of significant gifts, the two in the relationship may even be obligated to care for one another's children, or to undertake rescue of one other if endangered.

It turns out that Oedipus is also a $\xi^{\prime} \epsilon^{\prime} v o s$ in this latter sense: the one polluted and hated by the gods turns out to be the person who will protect Athens and who will keep it safe, precisely through being welcomed in by its host, Theseus. Theseus sees in Oedipus what Oedipus is blind to seeing, namely, the possibility that the polluted one, too, is under the care of Zeus Xenios, and can return, gift for gift,

\footnotetext{
27 Andreas Markantonatos, Oedipus at Colonus: Sophocles, Athens, and the World (Berlin: De Gruyter, 2007), 38-9.

${ }^{28}$ Hammond, Strangeness of Tragedy, 86; Joseph Wilson, The Hero and the City: An Interpretation of Sophocles' Oedipus at Colonus (Ann Arbor: University of Michigan Press, 1997), 82-7.
} 
protection in exchange for protection. Oedipus will give Theseus the gift of his protection, and in exchange, Theseus will grant Oedipus the protection of his children and a heroic status in his burial at Colonus. ${ }^{29}$

Moreover, Theseus explains that Oedipus is not a stranger in a moral sense. Both Theseus and Oedipus are men, who share a

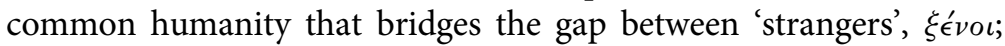
in this sense, Theseus suggests that no $\xi \epsilon$ 'vos is completely an 'outsider', if only because he knows what it means to be human. Theseus will not turn him away, not even when he possesses full knowledge of Oedipus' identity and his actions. While Polyneices insists on hiding his father's curse from his men, claiming that it is best for a leader only to tell of one's strengths, not weaknesses, Theseus is a leader willing to speak of himself in his wholeness, and to receive both strength and weakness in listening. He is aware of human vulnerability and accepting of it, as a constitutive part of the city. Such awareness helps to constitute his ability to be fair, rational, and evenhanded in treatment of Oedipus; that is, awareness of limit informs how Theseus embodies classical Greek virtues such as wisdom, courage, and moderation in his dealings with others. ${ }^{30}$ His listening to this story embodies the reciprocity of speech for Theseus, and also his receptiveness to this stranger grounded in a reception of his own experiences of estrangement. Here Sophocles presents not a vision of human wisdom that rejects reason, but rather one that insists that wisdom must be informed by awareness of limit and understanding of limit in others. Theseus acts rationally, but warmly here, and his considered judgements stem in part from reflection upon his own prior experience including its affective elements. Theseus can better understand limit in Oedipus than others because Theseus has a wisdom in which his own experience has been transformed into a considered sympathy for others. He does not express anger about his past, but rather utilizes those difficult past experiences in order to cultivate this new politically friendly relationship with Oedipus. To this extent, Sophocles does not reject the rational in favour of a tragic

\footnotetext{
29 Wilson, Hero and the City, 86.

30 As Blundell argues, Theseus embodies the classical Greek virtues of justice, courage, sound-mindedness, and piety. See Blundell, Helping Friends and Harming Enemies, 248-53.
} 
vision that is anti-rational or non-rational; rather, the rational itself includes an affective element. ${ }^{31}$

Indeed, Oedipus becomes representative of something much greater than himself after his death. As Budelmann has pointed out, Sophocles' language about Oedipus suddenly shifts after the death, so that he is no longer called by name, but only obliquely by indeterminate references that allude to him, for the last 150 lines of the play. ${ }^{32} \mathrm{He}$ offers the example of Theseus' instructions to Antigone and Ismene: 'Girls, that man ( $\kappa \in \hat{i} \nu o s)$ told me that no one should approach those places, or name the holy tomb which that man occupies ( $\kappa \epsilon i v$ vos $\left.\epsilon^{\prime} \chi \epsilon \iota\right)$ (1763-5).' Here, the use of the indeterminate $\kappa \epsilon \hat{\imath} v o s$ to name Oedipus reinforces the sense of a supernatural transformation that occurs with Oedipus (as do the clap of thunder and the divine voice mentioned at 1621-8). ${ }^{33}$ Theseus must shield his eyes so that even he does not directly witness Oedipus' transformation, which he describes as $\delta \epsilon \iota \nu$ s $^{\prime}$ (powerful). Here, again, the term Oedipus had used to describe the 'terribleness' of his crimes is transformed into a positive power for the city. ${ }^{34}$ Oedipus the $\xi$ '́vos becomes transformed into something greater than his individuated identity, to become 'the one' who protects Athens. ${ }^{35}$

Theseus alludes to his own history as a $\xi^{\prime} \epsilon^{\prime}$ os in the passage quoted above (561-9), he does not offer details of his exile. While the text does not elaborate, that Sophocles alludes to the exile suggests that he expects his audience to know something of the details of his

31 Here I distinguish my analysis both from that of Nietzsche, who looks to Sophocles as the last great tragic thinker before the advent of Socratic rationalism, and from those who find a more theoretical orientation in Sophocles. For the former, see Nietzsche's Birth of Tragedy, trans. Walter Kaufman (New York: Vintage, 1967). For an example of the latter, see Ahrensdorf, Greek Tragedy and Political Philosophy. Ahrensdorf also argues for Theseus' sympathetic nature, but understands the rationale in Theseus to be based on an ability to sympathize with others' self-interest. I suggest the reverse: that Theseus can understand others' limit and need on the basis of a shared 'interest' in having one's vulnerability hospitably received. Thus, his piety and wisdom are interconnected.

${ }^{32}$ Felix Budelmann, The Language of Sophocles: Communality, Communication, and Involvement (Cambridge: Cambridge University Press, 2000), 42-3.

33 Budelmann, The Language of Sophocles, 42-3.

34 Hammond, Strangeness of Tragedy, 91.

35 While many editors have read Theseus as offering citizenship to Oedipus at line 637, Wilson convincingly argues that the required emendation of the text from $\dot{\epsilon}^{\prime} \mu \pi \alpha^{\prime} \lambda_{\iota \nu}$ to $\dot{\epsilon}^{\prime} \mu \pi o^{\prime} \lambda \iota v$ is not borne out by any other textual evidence that Theseus makes Oedipus a citizen. See Wilson, Hero and the City, chapter 5. Oedipus becomes much more than a citizen here; he is a heroic presence. 
difficulties. Theseus struggled in his long trip to return to Athens after being raised in the land of his mother, so that he might take his birthright as ruler of Athens. His welcome from his father Aegeus was somewhat mixed, at best, as he welcomed Theseus initially with suspicion, and his wife Medea attempted to kill him when she realized his true identity as Aegeus' son. Some mythical accounts of Theseus also feature him as the product of a union that was lacking in full consent: one story says that his mother, daughter of a local king, lay with Aegeus when her father made him drunk as a way of guaranteeing his progeny a place in the royal order. Theseus' mother's father was King Pittheus, a son of Pelops; thus, Theseus, like Oedipus, comes from a family lineage cursed by the gods. We might recall that Pelops is killed by his father Tantalus to be served up as food for the gods in a testing of divine omniscience, an act that becomes the root source of the curse laid upon the house of Atreus, Menelaos, and Agamemnon. Theseus' father and Oedipus' father also have a history together, for the story goes that Laius fell in love with one of Pelops' sons and so carried him off, but Pelops (once his son was recovered) did not wish to punish Laius on account of love, only to send him away. Father and son, Pelops and Theseus, both possess a common sensitivity to human fault and limit that Oedipus and his sons seem to have lacked.

In the Athenian sensibility, Theseus was seen as the unifier of

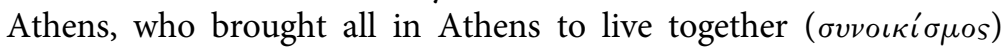
under a common ruler and a capital city, instead of being a number of independent demes or villages. While, in the archaic period, images of Theseus as a brutish philanderer dominated, under the Athenian democracy Theseus was raised to near cult status as a benevolent king. His role as hero of Athens became so significant that in $476 / 5$, in response to an oracle that demanded the recovery of Theseus' bones, Cimon led a procession containing what were said to be his remains, which were then enshrined in a sanctuary in the mid-fifth century. ${ }^{36}$ Additionally, a celebration of Theseus, the Oscophoria, took place in part at the temple at Skiron, where traditionally Theseus was cleansed of his murder of robbers before entering Athens to take his place as

\footnotetext{
${ }^{36}$ Walker, Theseus and Athens, 56-61. As Cimon was a conservative Athenian, Walker suggests the use of Theseus was not his first choice, but rather a concession to the democracy that bolstered Cimon's popularity at a time of reform. Markantonatos notes that Sophocles himself received a statue of Asclepius into his home and was deeply involved in hero cults, no doubt an influence upon his playwriting here. See Markantonatos, Oedipus at Colonus, 15-16.
} 
his father's son. ${ }^{37}$ Theseus has the experience of being polluted, but then also cleansed of his pollution. Thus, there are strong parallels between Oedipus' fate, as the one who protects Athens at its boundaries through the presence of his dead body, and the presence of Theseus' body as Athens' protector and guarantor of democracy. The festival's annual presence at the Skiron, at the edge of Attica, resonates strongly with the idea that Oedipus, too, is buried at a boundary, i.e. just outside its walls. The boundary of Athens is thus both presented as significant for distinguishing citizen from non-citizen, but understood as permeable, as that which can be crossed so that those such as Theseus who were once 'outside' can also belong.

Sophocles offers here as part of Theseus' unifying talent, his desire to include all in 'dwelling together'. In the light of Theseus' political role as unifier of Athens, we might even see his claim that he will turn away no stranger as Sophocles' own reflection upon the centrality of inclusiveness of the city, that no matter how 'outside' of the city a person may seem to be, Athenian democracy includes 'all' in its community. ${ }^{38}$ While the people, the $\delta \epsilon{ }^{\prime} \mu o s$, was once simply a part of the $\pi o^{\prime} \lambda_{\iota s}$, under Theseus $\delta \epsilon^{\prime} \mu o s$ and $\pi o^{\prime} \lambda_{\iota s}$ were united, so that the people and the city were now one and the same in the self-understanding of the democracy. Theseus' image was a visible presence in political and religious sites in Athens. In $460 \mathrm{BCE}$, a statue of Theseus lifting the rock to take his father's sword, the source of his identity as Aegeus' true son, was set up on the Acropolis, and in 438/7, his image as conqueror of the Amazonians appeared on the shield of the statue of Athena, and his presence on the friezes of buildings such as the Hephaisteion and Greek vases of the time is well documented. ${ }^{39}$

Much later, Plutarch reports that Theseus was unparalleled in his care and concern for those who were deemed to be 'outside' the city. He writes of Theseus:

Farther yet designing to enlarge his city, he invited all strangers to come and enjoy equal privileges with the natives, and it is said that the common form,

37 Walker, Theseus and Athens, 98-9.

38 In contrast, Walker argues that Sophocles offers Colonus as an aristocratic alternative to democracy, in emphasizing Theseus' kingly nature, in contrast to the presentation in Euripides' Suppliant Women. See along similar lines, Wilson, Hero and the City, 198-200, who sees this as more anti-democratic sentiment on Sophocles' part.

39 Walker, Theseus and Athens, 64-6. 
'Come hither all ye people,' was the words that Theseus proclaimed when he thus set up a commonwealth, in a manner, for all nations. ${ }^{40}$

Sophocles is innovative in his use of Colonus as the locale of Oedipus' burial, and refers not to Athens, but to Attica (the countryside surrounding Athens), as if to emphasize the inclusion of both country and city as part of Athens's full identity. ${ }^{41}$ As Hammond insightfully notes, when Oedipus had said of his arrival, ' $\xi v \mu \phi o \rho \hat{s} s \dot{\xi} v \theta_{\eta} \eta \mu$ ' $\epsilon \mu \hat{\eta} s$,' or 'It is the sign of my destiny,' he uses two terms in a row that connote the joining together of what has been apart (line 47). ${ }^{42}$ Theseus also is he who has brought together what was previously apart, so that all might dwell together. Here Sophocles associates Theseus' bringing together of the city with Oedipus' arrival at his destiny. While Sophocles is better known for his conservative orientation toward aristocracy, Sophocles' last work displays a care and concern for inclusion and gentleness in the reception of countryman, exile, and stranger into Athens, precisely at a time when the Athenians were facing defeat in war and considerable political division. ${ }^{43}$

Theseus, then, might be said to be the true hero of Oedipus at Colonus, for he is the reversal of Oedipus, a man who began in exile, but ends in gentle rule. Instead of ending in harsh judgement against those who had harmed him, Theseus welcomes with hospitality those who have received harm. Theseus might be said to be the only 'happy reversal' of the play, and his presence as a gentle and compassionate ruler has consequences not only for himself, but for his whole city. He replaces the rule of force with the rule of law, for law treats all alike according to a common, single principle, as force cannot. While Thebes had suffered because of Oedipus' pollution, Athens will prosper because of its reception of Oedipus in his pollution and in his misery. While Oedipus' family will suffer greatly because of his fate, and because of his reaction to that Fate, the families in the audience of the plays, in Athens, are assured of the benevolent protection of the city because of Theseus' care for the exiled and polluted one.

\footnotetext{
${ }^{40}$ Plutarch, Lives, Vol. I, trans. J. Dryden with revisions by A. H. Clough (New York: A. L. Burt, n.d.), 23.

${ }^{41}$ Walker, Theseus and Athens, 174-5.

42 Hammond, Strangeness of Tragedy, 88.

${ }^{43}$ Markantonatos, Oedipus at Colonus, 10-21, convincingly lays out the argument for the biographical indications of a Sophocles who was strongly democratic late in life; see also his reflections on the significance of the drama as a way to bolster Athens at a time of decline in Markantonatos, Oedipus at Colonus, 157-67.
} 
Theseus is the true possessor of wisdom in this dialogue, even as Oedipus is Athens' guarantor of its longevity. Oedipus' suffering body is the source of the city's protection, an embodied witness of the power of suffering to protect as well as to cause distress. ${ }^{44}$ Theseus' wisdom is gleaned from his own experience of exile and suffering, which brings compassion and care to his rule. His is not a divine wisdom, but a human one informed by a sense of his own limits and compassion for others in their humanity. ${ }^{45}$ Oedipus' presence in death, outside of the city, is also the city's protection, for his protection arises from the incorporation of his weakness. Sophocles was also offering his own political community a reflection on the necessity for Athens to embody this approach to political community as a 'dwelling together', not only of strong, but also of weak.

44 Ballengee, Wound and the Witness, 59-64. Ballengee views Oedipus' physical woundedness as holding the memory of his past deeds, a physical presence that grants his body political power in its ability to exact vengeance on threats to Athens. However, Oedipus is also positively characterized as a blessing to Athens, a positive protective presence to the city.

45 Along similar lines, Mills remarks of Theseus, 'he is no deus ex machina, since he has no power or knowledge beyond what might be expected of a wise human king; he can mitigate suffering, but he cannot explain it'. See Mills, Theseus, Tragedy, 168. 


\section{Pity as a Civic Virtue in Sophocles' Philoctetes}

The Philoctetes does not open with its main character, because at the start of the play, no dialogue is possible for him. The first word of the dialogue in Greek is $\dot{a} \kappa \tau \eta^{\prime}$, or shore, an appropriate beginning since Philoctetes himself belongs at the periphery, the edge, the space in between belonging to society-to which he naturally as a human being forms a part-and being an island to himself in his isolation on Lemnos. Lemnos is a large island west of Troy, and so it is somewhat surprising when Odysseus describes it as completely uninhabited, a place that no one even visits. Because of this isolation, we find Philoctetes to be someone in a place that is 'in between'. Physically, he is entirely separated from his fellow comrades in arms with whom he willingly went to fight at Troy. He lacks the ability to speak with any other human being, to communicate. He is also excluded from the company of the gods, insofar as his treading on the sacred ground of Chryses, en route to Troy, is the cause of his oozing wound, and the ground of his subsequent exclusion from the company of his own men. At the same time, we know Philoctetes to be by nature a social man. While Odysseus himself is said to have feigned madness in order to avoid fighting in the war, Philoctetes went willingly, bringing seven armies with him. His bow and his subsequent military power, so highly sought after by Odysseus in this final year at Troy, are the result of a gift of Herakles. When Herakles desires to die to escape the intolerable pain of his poisoned cloak, it is Philoctetes who willingly sets the fire to the pyre after others refuse, allowing Herakles to escape his pain. Although he is severely wounded, Philoctetes' empty cave nonetheless contains traces of civilization: a crudely carved wooden cup; a bed made of leaves; material for making a 
fire; and especially Philoctetes' bow, which allows him to slay birds and to survive off their meat. While isolated from the materiality and sociality of civilization, Philoctetes nonetheless endeavours to live a distinctively human life. The 'shore' is thus an image of Philoctetes himself, not only as in between island and world, but also as representative of someone who is located in between isolation and society, between brutishness and culture, between nature and civilization.

Sophocles presents not only Philoctetes' physical wounds, but also his existence in this 'in between' space as that which grants him access into humanity in a special way possible for those at the margins. As a marginal figure, he belongs to both the human and the inhuman. As the shore is both sea and sand, Philoctetes is both social because human, and yet, denied the sociality that he craves. But what is important about Philoctetes is not only the fact of his wound. Surely his extreme physical pain matters to him, and at times occupies his attention to the exclusion of many things. But even for Philoctetes, this wound is only a figure of much deeper wounds suffered in his exclusion from society, from the company of fellow human beings. He knows his need for society, precisely through its being denied to him. Philoctetes eventually gains a deeper access to his humanity, precisely through others' denial of it. His experience of longing for others opens him up to a deeper understanding of his own nature, by virtue of his lack. And it is this longing and need that lead another, Neoptolemus, to his growth in the political community. The vulnerable and wounded are not merely to be tolerated or accepted; rather, Sophocles presents Philoctetes' weakness as contributing to the growth of Neoptolemus' virtue, and to the growth of the political community.

In this chapter, I argue that Sophocles develops the notion of two political virtues: first, pity as a political virtue and, second, the virtue of being able to accommodate unjust harm properly. The vulnerability of individuals such as Philoctetes demands the need for both a kind of pity that verges on interpersonal compassion (as found in Neoptolemus), but also the ability to respond properly to unjust harm. Our own contemporary cultural tendency is to think of such musings about vulnerability and pity as private, as apolitical, as better suited to the realm of psychology than to the realm of politics. However, Sophocles presents Philoctetes' physical and emotional woundedness 
as a distinctively political problem. Neoptolemus is not simply engaged in an interpersonal relationship with Philoctetes; he is a political emissary who seeks to return Philoctetes to Troy. Odysseus is not presented only as an individual concerned with his own glory. In some ways, he stands for a fundamental problem in politics itself, namely, the tendency of politics to move toward dissembling and even ruthlessness in the working out of its larger goals. Odysseus and the Greeks wish to succeed in the war against Troy, and Philoctetes in his individuality is subsumed to that larger project and its demands. To this extent, Odysseus and his lies possess a kind of 'reasonableness', from the point of view of achieving 'greater' political ends. Thus, Neoptolemus must work out for himself how to reconcile his care for Philoctetes and for moral integrity, against the demands of his political world. Philoctetes must learn how to accommodate the past harm done to him, in the light of Odysseus' refusal to express sorrow, into his own citizenship as part of an imperfect Greek community.

Odysseus initially describes Philoctetes to Neoptolemus primarily as one who cries, who makes noise. He claims that Philoctetes was abandoned because his 'savage cries (áypíaıs) and ill-omened words

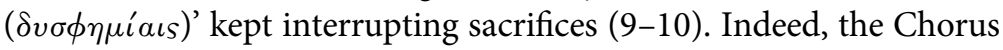
and Neoptolemus discover Philoctetes by his constant cries, so that we might expect to find a wild man, a savage, in that first encounter. But instead of wildness, we find something else entirely. Philoctetes' first sounds, once he encounters men again, are not screams, but a speech; in fact, he gives a speech about speeches. Philoctetes pleads that the others speak to him (he is especially hopeful from their clothing that it will be in Greek, which he can understand) because primary to his own healing is communication:

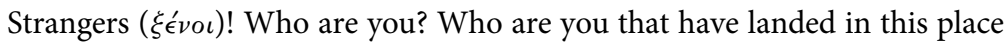
without good mooring or inhabitants? Of what homeland are you, and what family might I be right to say? The style of your clothing is Greek, always beloved to me. I want to hear your voice $(\phi \omega \nu \hat{\eta})$ ). Don't shrink in dread from my wildness, but pity me a man miserable, alone, abandoned, friendless. 
Speak, if you have arrived in friendship. Answer me, for it is not appropriate that I should miss ( $\dot{\alpha} \mu \alpha \rho \tau \epsilon \hat{\imath} \nu)$ this from you or you from me. $(219-31)^{1}$

Philoctetes asks a whole series of questions, questions that demand answers, and whose answers demand an expression of identity: the speakers' home, ethnicity, language, and whether their presence is one of friendship or not. Every one of these first questions posed by Philoctetes expresses the need for society in both content and in form: the content concerns the social nexus into which his visitors belong, and whether Philoctetes in some way belongs to that same nexus, as Greek or friend; but the form of speaking itself for Philoctetes is also already connective; and his question as a question is connective, or at least desirous of connection. Questions are speech acts that embody longing of some sort-whether the longing for an answer to a problematic philosophical question, or the longing for the contact of speech itself, a question is an invitation to another person, or to the world, to offer some kind of an answer. A question is an expression of not-yet-having what one desires, of lack, of need. Philoctetes is a needy man, and is far past the point of denying his neediness. For him, that they would somehow miss one another $(\dot{\alpha} \mu \alpha \rho \tau \epsilon \hat{\imath} \nu)$ is beyond what is reasonable for a man to endure; the use of $\dot{\alpha} \mu \alpha \rho \tau \epsilon \hat{\imath} \nu$ here gives us the sense that it would be almost a moral or religious failing.

When Neoptolemus offers the briefest of answers, 'Stranger $\left(\xi \xi^{\prime} \nu^{\prime}\right)$, know first that we are Greeks (232),' Philoctetes makes no effort to hide his joy in finding this moment of connection, exclaiming, 'What

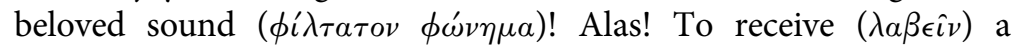
greeting from such a man after such a long time!' (234-5). The sound of the Greek is a 'beloved' experience for him, because of the fellowship that it offers, the possibility of meaningful exchange, the experience of gift and giver, of reception and recipient making a return of the gift of the word, in each reply. Philoctetes is deeply aware of the giftedness of the word, of $\lambda$ ó yos, almost exuberant with its joy.

1 Translations in this chapter are my own. Greek text is from Sophocles, The Philoctetes of Sophocles, edited with introduction and notes by Richard Jebb (Cambridge: Cambridge University Press, 1898). Perseus Digital Library, <http:// www.perseus.tufts.edu/hopper/text?doc=Perseus\%3atext\%3a1999.01.0193>, accessed 2010-12. 
Philoctetes' eager desire for speech is matched only by Neoptolemus' hesitance to engage in speech, a hesitancy that I think we can fairly attribute to two causes: first, Odysseus has warned Neoptolemus that Philoctetes may be resentful of Odysseus or anyone associated with him. The image he has conveyed to Neoptolemus is to be careful not to be shot at with the powerful bow. Second, Neoptolemus has been sent by Odysseus to use deceitful speech to trick Philoctetes into handing over the bow, but Neoptolemus from the beginning finds such a use of speech to lack nobility and goodness. He is most hesitant to begin speaking, because of the possibility that words may be used for deception, not friendship, to steal, rather than to make a gift. We find then, in these earliest exchanges between Philoctetes and Neoptolemus, a prefiguring of a choice Neoptolemus himself will have to make about the proper use of speech in response to his encounter with Philoctetes' woundedness.

Speech, especially persuasive speech, will be a central topic of this play, and here we see the necessity of speech for a human being at its most elemental. At its most basic level, speech presumes contact, and the play's concern centres around two interrelated issues: first, the narrower issue as to whether false persuasive speech for the sake of a just goal (such as the defeat of Troy) is an acceptable means to that end, and second, the broader issue as to what speech ought to communicate. ${ }^{2}$ For Neoptolemus, his own development is to regard speech not only as a means of effecting action, but more importantly, as a communication of the self, or of two selves to one another. Neoptolemus' window into the need of speech to be interpersonal, an authentic communication of one person to another, arises (eventually) from his contact with one who has so long been deprived of such communication. It is Philoctetes' lack that will expose his neediness for communication to Neoptolemus, and so also communicate a larger truth about speech to him. Neoptolemus learns that speech is that which connects persons, and is not only a means of accomplishing goals, as Odysseus would have it. To this extent, Neoptolemus preserves his natural inclination toward speech that is measured by virtue, rather than political efficacy; his encounter with Philoctetes

2 As Rose demonstrates, many anthropological claims of the sophists about survival, the development of society, and the need for persuasive speech enter into the drama and narrative of the play. See Peter Rose, 'Sophocles' Philoctetes and the Teachings of the Sophists', Harvard Studies in Classical Philology 80 (1976), 49-105. 
reinforces his understanding of justice and virtue as central to good speech. ${ }^{3}$ Philoctetes' need, and even his pain, are what assist Neoptolemus in growing in his understanding of speech as requiring a care for virtue. Neoptolemus' sympathy for Philoctetes allows him to resist an understanding of speech as oriented exclusively toward political efficacy, instead moving him to understand speech as oriented toward building political community and friendship.

When Neoptolemus feigns ignorance of Philoctetes' story, Philoctetes seeks to communicate it. His self-understanding is not merely that he is wounded, but he says that his comrades abandoned him (267). To be sure, Philoctetes' wound itself is painful, but his suffering comes from his understanding of himself as abandoned, desolate, left alone with no one to witness the pain, let alone to share in it with him, even through a minimal act of sympathy, as an experience of choosing to take on and experience some portion of pain with another. This idea of being known, his pain being witnessed, is apparent in his deep disappointment that Neoptolemus has not even heard his story. Part of the suffering, to be sure, is simply the absence of human contact, and his sorrow that he is not even missed enough for stories to be told about him. But the suffering from abandonment in this case is worse, for the very reason for his being abandoned is that his pain was too much for the other Greeks to bear. It was, for them, an interruption, a disturbance of their senses of smell and sound. However, perhaps his cries also disrupted the others precisely because they did call forth a certain shared feeling, a feeling-with Philoctetes of extreme discomfort, that could not be ignored, or put away, except by putting him away. So while Philoctetes is in pain, he suffers less from the wounded leg than from the wounds of rejection, from the judgement and evaluation that his pain is too much to bear, that the community will not bear his pain along with him. Philoctetes becomes identified not as a man who has pain, but as pain, as the one who cries and disturbs the order. His identity becomes submerged in his being 'the wounded one', when for Philoctetes, he is still a Greek, a warrior, the

3 Biancalana sets out a similar distinction between virtue and efficacy in speech, but sees it as a direct criticism of Athenian politics when the play was produced around 409, shortly after the political revolt of 411 вCE. See Joseph Biancalana, 'The Politics and Laws of Philoctetes', Law and Literature 17 (2) (2005), 155-82. I agree, but wish to link vulnerability and pity to political community in a way that Biancalana does not. See also Charles Segal, Tragedy and Civilization: An Interpretation of Sophocles (Norman, Okla.: University of Oklahoma Press, 1999), 333-40. 
one who mastered the bow of Herakles, the one who was willing to fight for his fellow men. He does not wish to be defined entirely by his pain, but ironically, in being cast out from society, is left with little else except his pain, through the exclusion of all the rest.

Philoctetes survives-just barely-because he is able to crawl out and to find food, to hunt with the bow, and to create fire. He says, 'When there was no fire, striking stone against stone, I'd bring to light the hidden spark ( $\left.\epsilon^{\prime} \phi \eta \nu^{\prime} a{ }^{\prime} \phi \alpha \nu \tau o v \phi \hat{\omega} s\right)$, which always saved me' (296-7). Philoctetes' three technologies available to him are fire, shelter, and the bow. ${ }^{4}$ These are his only bridge to civilization, as well as his means of survival, when deprived of the culture and society of others. In Sophocles' Greece, when a new colony was founded, a symbolic fire was taken from the public hearth of the Prytaneum, to the new city, and used to light its hearth. In the light of this tradition, we might imagine the importance of fire in the Greek understanding of a public space. Philoctetes has a private fire, which he must strike anew each time, and is deprived of the public hearth, the fire of the city that burns for the whole community, and not only a private home. Still, the presence of fire is more than a mere necessity for him, and serves as a reminder of the civilization that he has left behind.

Herakles' bow is also representative of Philoctetes' middle place between solitary existence and civilization, for its original purpose in being with him was for use in the Trojan War. As such, his bow was intended to serve him as a warrior and as an ally in the Greek agreement to defend the guest-host relationship. On the isolated island, however, Philoctetes' bow is primarily an instrument that can bring him food, in the absence of the physical ability to work the ground and grow food. Instead of fighting Trojans, he is killing birds. His bow is also his last remaining vestige of his power; it is the sole reason that Odysseus returns for Philoctetes and wishes to bring him back. As Segal argues, the bow connects Philoctetes to the divine; in the absence of wine, he was unable to perform sacrifices to the gods while on Lemnos, but his bow was invested with Herakles' greatness and becomes almost a 'talisman' of the dead king. ${ }^{5}$ The bow soon also becomes a sign of friendship between Neoptolemus and Philoctetes, when the latter allows the young man to hold it and even to protect it,

\footnotetext{
${ }^{4}$ Later Philoctetes also mentions the herb he found that is somewhat capable of soothing his pain.

${ }^{5}$ Segal, Tragedy and Civilization, 294.
} 
as a sign of his trust in their bond. By its very structure, a bow is connective; in its exchange between the two men, the bow also becomes a symbol of their connection. Thus, the bow connects Philoctetes to the divine Herakles, but also back again to the social and political world through Neoptolemus.

Rather quickly into their conversation, Philoctetes receives the experience of connection and of empathy that he desires, but in the form of a deception. Neoptolemus seeks to gain Philoctetes' trust and confidence by suggesting that they share a common enemy among the leaders of Troy. He tells the story of how Odysseus denied him the armour that had belonged to his father, Achilles, and emphasizes his own anger at Odysseus' lack of honour. The psychological aim of such a story is to ally himself with the wounded man through a kind of reverse empathy. Neoptolemus presents himself as one with whom Philoctetes can sympathize. He presents himself as if he were the one in need; rather than directly sympathizing with Philoctetes, Neoptolemus engages him by drawing him into his own false story. Philoctetes can identify with the story insofar as he can see himself, or aspects of himself, within it. Thus, in this act of sympathizing with the false Neoptolemus, Philoctetes is, in a way, sympathizing with himself. His own pain is put on display for him, albeit in a modified form. He is both the suffering one, and the one witnessing the suffering, through this story of anguish similar to his being placed before him in the story of Neoptolemus. Through the other's narrative, he can understand something of his own suffering, and find relief in its being shared by another. Thus, the tragedy exhibits for us the ways in which the witnessing to pain, and sharing in it, to some extent lightens its load for those who suffer, and can even draw them into a mutual fellowship. As the final chapter of this book will argue, such mediation and sharing of suffering is also key to the audience's experience of tragedy, an experience that makes possible sympathy not only between audience and characters, but also even between the members of the audience.

Neoptolemus' account of his own suffering resonates with Philoctetes (343-90). The most obvious resonance rests upon their shared sense of anger with Odysseus, who is supposedly responsible for denying him his father Achilles' armour, a typical gift for a son after his father's death. But his story sets forth other elements present in Philoctetes' life, too: Neoptolemus feels the loss of his father, and his separation from the one he loves, as does Philoctetes feel strongly 
the separation from his people. Odysseus has supposedly told Neoptolemus that the reason he may not have Achilles' armour is that 'You were not with us, but instead somewhere else, where you shouldn't have been' (379). But this sentence also articulates perfectly Philoctetes' perception of his own situation with respect to Troy: that he cannot share in the glory of war, because he is somewhere else, and should not be. Lemnos for Philoctetes is hardly even a place, for the island is not defined by any people; when he leaves, he says that he is leaving behind a 'dwelling', but not a 'home'. Just as in Homer, Odysseus is ov" $\tau \iota s$, nobody, and no one, on the island of the Cyclops, when denied the presence of a civilized community, Philoctetes can see his own location only as 'somewhere else'; he is nowhere and somewhere all at once.

Philoctetes begs Neoptolemus not to leave him by making himself a suppliant. In asking a question, a person makes himself somewhat vulnerable to another person or to reality itself, in admitting a need for something he lacks, and his desire to have that which he does not yet possess. Supplication is an even more intensive expression of lack

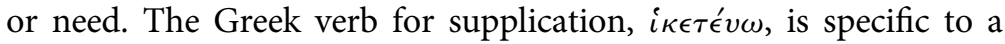
ritualized set of practices that place a supplicant into a specific relation to the one whom he supplicates. As Naiden has demonstrated, the difference between a supplication to a god and a prayer is that in supplication, the god must be present (as in an epiphany), while prayer is possible when the god is not literally present. ${ }^{6}$ Thus, supplication always implies asking for an immediate response, in a way that prayer need not; it is a two-way social act. Here, Philoctetes supplicates not only to get the goal he wants (to leave Lemnos), but also to continue social interaction (the supplication itself assures that he will not be alone, so long as the conversation and act of supplication continues). His supplication is an expression of his desire for home, and of his loneliness in dreading the possibility of yet another abandonment.

In kneeling or grasping the knees of another, a supplicant makes himself vulnerable to the other, by displaying in physical posture his weakness compared to the one he is approaching (kneeling, or lowering oneself expresses one's lower station, but also makes one vulnerable to attack from above). His verbal request, accompanied by

${ }^{6}$ F. S. Naiden, Ancient Supplication (Oxford: Oxford University Press, 1996), 7-8.

This is an open access version of the publication distributed under the terms of the Creative Commons AttributionNonCommercial-NoDerivs licence (http://creativecommons.org/licenses/by-nc-nd/3.0/), which permits non-commercial reproduction and distribution of the work, in any medium, provided the original work is not altered or transformed in any way, and that the work is properly cited. For commercial re-use, please contact academic.permissions@oup.com 
the physical gesture, is desperate. He explicitly asks Neoptolemus to

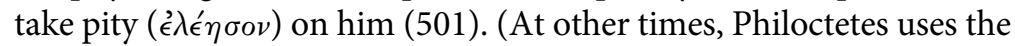

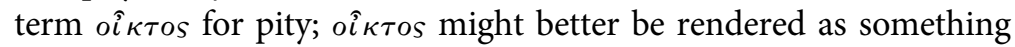
like pity/grief as it expresses elements of lamentation as well as pity; when Aristotle discusses pity, he restricts himself entirely to the term $\left.\epsilon^{\prime \prime} \lambda \cos ^{7}{ }^{7}\right)$

Konstan's work on the nature of pity in Greek and Roman thought briefly attends to Philoctetes. As part of his analysis of the Aristotelian concept of pity, Konstan points out that Aristotle requires vulnerability to suffering as a condition of pity. Aristotle writes that there are two sorts of people that are unlikely to feel pity: those who have lost everything, for they are not likely to fear the possibility of losing anything further; and those who are extremely fortunate, for they are not likely to believe that they might suffer the same sort of experience as the one who is now suffering (Rhetoric 2. 8). In other words, Aristotle makes as a condition of experiencing pity my ability to identify myself as capable of being in the same or a similar situation. On the one hand, to have pity for another requires that we have different current fortunes (if we are both sharing the same affliction, it is not pity, but something more like commiseration); on the other hand, I need to be able to imagine myself into the position in which you are. For this reason, Aristotle suggests that most often we are capable of pity for those who are more like us in age, station in life, or character. ${ }^{8}$ We must also understand ourselves as vulnerable, and so as like the other who asks for our pity.

At the same time, pity is distinct from sympathy, in which the emotion is more closely shared between two people. Konstan shows

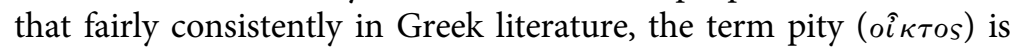
excluded from reference to family members' feelings for one another, and for the emotions of friends who witness one other's suffering. Pity requires a certain emotional distance, a continued stance of being a bit of an observer, rather than simply one who suffers the same as the one pitied, while sympathy ( $\sigma v \mu \pi \alpha \dot{\alpha} \theta \iota \alpha$, a term that arises only after the classical period) or other terms such as $\sigma v v \alpha \lambda \gamma \in \hat{\imath} \nu$ (to feel pain with) or $\sigma v \lambda v \pi \eta$ бoraı (to feel pain or grieve with) connote a

\footnotetext{
7 See David Konstan, The Emotions of the Ancient Greeks: Studies in Aristotle and Greek Literature (Toronto: University of Toronto Press, 2006), 111-28.

${ }^{8}$ Konstan, Emotions of the Ancient Greeks, 49-50.
} 
deeper sharing of the experience that we might expect in friendship or familial relationships. ${ }^{9}$

We might ask, then, what allows Neoptolemus to take pity on Philoctetes, what in his character, experience, or disposition opens up the possibility of pity that also moves him to action, when Philoctetes' comrades had abandoned him as a reaction to his wound and his cries. Of course, Neoptolemus and Odysseus have come for Philoctetes' bow, so that the Trojan War might be won. However much this is a part of Neoptolemus' own motivation, in his reluctant agreement that they must deceive Philoctetes, eventually the 'better part' of Neoptolemus wins out, the part of Neoptolemus that understands good speech to be virtuous, and not only effective. Good speech in this case also means being responsive to Philoctetes as a man, not only as the possessor of the bow; that is, Neoptolemus understands Philoctetes' dignity as a human being to be more significant than his status as possessor of the weapon that must be had in order to win Troy. ${ }^{10}$ We see the natural pity that Philoctetes incurs as a human being even in the Chorus' response to him as one of pity (317-18).

The use of the character of Neoptolemus as the one sent to retrieve Philoctetes is a Sophoclean innovation. While little is known of the Aeschylean and Euripidean versions of the play, aside from a firstcentury critical essay by Dio Chrysostom, we do know that Sophocles alone has Neoptolemus be Philoctetes' primary relationship on Lemnos; in both Aeschylus and Euripides, the conflict centres around Odysseus and his relation to Philoctetes. ${ }^{11}$ This dramatic innovation allows Sophocles to explore the significance of natural sympathy between human beings as the ground for a political bond. Neoptolemus has no direct connection to Philoctetes aside from being a Greek of noble class, and yet, his interpersonal bond to Philoctetes is profound as a result of their mutual encounter with his pain.

9 Konstan offers extensive evidence on this distinction between Greek terms; Emotions of the Ancient Greeks, 111-28.

10 See Martha Nussbaum, 'Consequences and Character in Sophocles' "Philoctetes"', Philosophy and Literature 1 (1) (Fall 1976), 47 which emphasizes Neoptolemus' concern that Philoctetes be free to choose.

11 See John S. Kieffer, 'Philoctetes and Arete', Classical Philology 37 (1) (January 1942), 38-50; Dio discusses the three Philoctetes tragedies in his 52nd and 59th Discourses. Dio Chrysostom, also called Dio of Prusa, was a first-century ce commentator, philosopher, and writer in the Roman Empire. 
The turning point for Neoptolemus seems to be neither entreaties to be pious, nor the praise of his good character heaped upon him, not even Philoctetes' claim that Neoptolemus is a 'friend' ( $\phi$ ì $\lambda$ os), though we might imagine that these words prepare the ground for Neoptolemus' renunciation of his deceitful rhetoric. Instead, Philoctetes' cries of pain, when an episode of especially acute suffering comes upon him, deeply affect Neoptolemus. As Philoctetes cries out both for relief from the pain, and for protection for his sacred bow (the only thing of worth to him aside from a pain-soothing herb), Neoptolemus exclaims that he feels Philoctetes' pain along with him and has been concerned for his troubles this whole time (806). In the midst of this pain, Philoctetes begs for Neoptolemus to light a fire to burn him, so that he might escape his pain (800-1), just as Philoctetes had once done for Herakles. ${ }^{12}$ While Neoptolemus ignores this request, he does give his oath that he will wait and will not leave without Philoctetes (813). When the wounded man falls asleep, Neoptolemus is faced with the possibility of recapitulating the previous episode in which Odysseus and his men abandoned him on the island (while he slept); but while the Chorus suggests that this is the most advantageous time for a clean get away now that he has the bow in hand, Neoptolemus remains. His reason is: 'I see $(\delta \rho \hat{\omega})$ that the hunt for the bow is in vain if we sail without him. For he is the one who must have the garland. He is the one that the god told us to bring back $(\kappa \circ \mu i \zeta \epsilon \iota \nu)^{\prime}$ (839-41).

Philoctetes' suffering produces a clear decision on Neoptolemus' part to bring back not only the bow, but also the man (whereas Odysseus thought stealing the bow to be the wisest course of action). While his reasons to the Chorus are that the mission includes taking back Philoctetes, not just the bow, as soon as the wounded man awakens, Neoptolemus can no longer contain his ambivalence over his next course of action. His increased rational understanding of Philoctetes as a man whose dignity must be respected, lest he deserve shame and disgrace, stems from an emotional, not simply purely rational, encounter with the man. ${ }^{13}$ That is, Sophocles presents this

\footnotetext{
12 Segal notes the traditional association of Lemnian fire with the volcanic fire of Mount Mosychlos, again suggesting that Philoctetes seeks to flee the gods and the heavens for the depths of the earth. See Segal, Tragedy and Civilization, 305.

13 See Anne Hawkins, 'Ethical Tragedy and Sophocles' "Philoctetes"', Classical World 92 (4) (1999), 337-57. Hawkins offers an account of the role of emotional response in Neoptolemus' ethical dilemma of the Philoctetes. See also Mary Whitlock
} 
young man's moral growth, and understanding of the right moral action to take with Philoctetes stems in part from a proper emotional response (feeling pity) to the suffering man. While Neoptolemus from the beginning suggests that it is not in his nature $\left({ }^{\prime \prime} \phi v v\right)$ to plot against others (88-9), his nature ( $\phi \dot{v} \sigma \iota s)$ can only be developed and brought to fruition through an encounter with the one who suffers. He also must reconcile Odysseus' claim that the oracle demands the return of Philoctetes with the question of the man's freedom; that is, he must try to understand piety better. ${ }^{14}$ Thus, the political problem of how to get Philoctetes back into the community and back to Troy, so that the Greeks may be victorious, requires an interpersonal, sympathetic encounter that allows Neoptolemus to grow morally. Such moral growth includes a proper emotional, as well as rational, component.

Indeed, one might say that Neoptolemus' moral growth comes to fruition when he is able to unify the emotional and rational elements within that have so far been in conflict, without excluding the complexity of their demands. Odysseus seems to rely solely on his judgement that piety and justice require that the bow be taken; he excludes compassion from his moral compass, or even to avoid internal conflict. In contrast, Neoptolemus' experience of pity significantly informs his exercise of reason, for the experience of witnessing the suffering man leads to his reasoned judgement that the proper moral response is to abide by his promise and to return the bow to Philoctetes. He manages to integrate his reasoned judgement about the best course of action with his affective response to the man. Neither Philoctetes nor Odysseus seems to manage such integration of feeling and reason: Odysseus excludes compassion, but Philoctetes seems completely under the sway of his immediate feelings, unable to consider the demands of political obligation. Philoctetes, too, must come to terms with his vulnerability, though differently from Neoptolemus.

Blundell, 'The Phusis of Neoptolemus in Sophocles' "Philoctetes"', Greece and Rome, Second Series 35 (2) (October 1988), 140; and Rose, 'Teachings of the Sophists', 74.

14 Charles Segal, 'Philoctetes and the Imperishable Piety', Hermes 105 (2) (1977), 133-58. 
Philoctetes is initially overjoyed when he awakes to find himself still surrounded by others, but Neoptolemus expresses confusion, disgust, and even pain in trying to discern what next to choose (see 911-21). Neoptolemus even uses the Greek term $\pi \alpha \pi \alpha \hat{\imath}$, the same exclamation that Philoctetes had earlier used when he was in pain, suggesting that Neoptolemus' pain over his own moral failing mirrors the physical pain that Philoctetes had experienced; it exhibits itself as much more than regret, or worry, but as taking on a physical, gut-wrenching quality (compare 895 and 785-6). Neoptolemus explains, 'It's not that I am leaving you, but rather I am sending you somewhere that will cause you distress. This is what's been grieving me $(\hat{\alpha} \nu \iota \hat{\omega} \mu a \iota)$ for so long' (912-13). His agony is understandable, for Neoptolemus must consider not only the justice and nobility of his actions towards Philoctetes, but also the question of piety. Odysseus has argued that if Neoptolemus obeys Odysseus he will nevertheless still be called 'the most pious of mortals' ( $\left.\epsilon \dot{v} \sigma \epsilon \beta \epsilon^{\prime} \sigma \tau \alpha \tau o s \beta \rho \sigma \hat{\omega} \nu\right)$ (85). While it is conceivable that Odysseus is simply claiming that one shameless act will not stand in the way of Neoptolemus' reputation for piety, if we take Odysseus to have a genuine concern for piety, then he might understand piety as demanding obedience to the oracle (83-5). Even so, Odysseus' sense of piety is subservient to his sense of his own glory and victory; it is Neoptolemus who is left struggling to reconcile the multiple demands of piety, politics, natural pity, and nobility. ${ }^{15}$

Philoctetes, understandably, feels betrayed, and demands the return of his bow. Here, we especially see how the bow has taken on the significance of a sign of friendship between them. Just as Herakles had offered it to Philoctetes not only as a reward for his relief from pain, but also as a sign of their connection to one another, ${ }^{16}$

15 Aristide Tessitore describes the potentially conflicting demands of piety and politics experienced by Neoptolemus in 'Justice, Politics, and Piety in Sophocles' Philoctetes', Review of Politics 65 (1) (Winter 2003), 61-88. Nussbaum suggests the good of all citizens is more significant than Odysseus' personal glory, but it is more accurate to say that Odysseus sees his own victory here as tied to the success of his mission, no matter what that means. See Nussbaum, 'Consequences and Character', 25-53.

16 As Avery points out, when Philoctetes addresses the bow at 1128-9, he says that it must pity ' $\tau o \dot{\nu}$ ' $H \rho \alpha ́ \kappa \lambda \epsilon \iota \nu \nu$ '; the use of the adjectival form of Herakles here links 
Philoctetes had allowed Neoptolemus to touch it as a sign of their friendship, a connection which had relieved much of the wounded man's pain of isolation. The bow is not only Philoctetes' only way to survive, in his lameness and inability to grow food for himself; more significantly, it is a sign of his honour and his strength. Traditionally, Herakles himself received the bow from Apollo; ${ }^{17}$ this bow, then, is also a sign of the friendship between the gods and human beings; but Philoctetes' frequent expressions of doubt as to the justice and care of the gods suggest his bow may be one of the last concrete signs of that divine-human care. In choosing to hand over this bow to Neoptolemus, he makes himself much more vulnerable than he had been before; in feeling betrayed in his moment of trust and vulnerability, he demands that the main sign of his vulnerable friendship with Neoptolemus be returned to him (924).

The moment of betrayal arises not in Neoptolemus' claim that the Greeks need the bow, but rather in his admission that his stories thus far have been a lie: the violation of trust experienced in deception is as significant for Philoctetes as the potential loss of the bow itself. Philoctetes' angry reaction to the betrayal is understandable, for while Philoctetes could have chosen differently, out of his great need and loneliness, he chose to open himself in friendship to Neoptolemus. One might imagine, for example, an alternative story of a man abandoned on an island because of his wound, who grows to hate others, to reject humanity in others and even in himself as a result of the rejection that he had experienced. Or imagine Philoctetes, after ten years, turned entirely to non-human concerns, separating himself from his humanity through a reserved asceticism. Philoctetes might reasonably have been distrustful of the strangers who arrived on his island, assuming that these human beings, too, were likely to bring him harm. Instead, Philoctetes lays himself bare to them in his need, hiding none of his suffering, neither his physical pain, nor his desire for friendship, community, and truth. Sophocles presents Philoctetes as far more willingly vulnerable than in the

Philoctetes closely to Herakles as his successor or even like a son. See Harry C. Avery, 'Heracles, Philoctetes, Neoptolemus', Hermes 93 (3) (1965), 293. For an excellent account of the many, layered nuances of the bow, see Segal, Tragedy and Civilization, 318-21.

17 Diodorus Siculus, 4. 14. 3. Diodorus Siculus, Library of History, Vol. II, Books 2. 35-4. 58 (Loeb), trans. C. H. Oldfather (Cambridge, MA: Harvard University Press, 1935). 
Euripidean version of the play in which, Dio tells us, Philoctetes' first response to Odysseus' arrival and proclamation that he is a Greek is that he will shoot any Greek he meets with his bow. ${ }^{18}$ This Philoctetes is aware of the dangers, but willing to encounter them. He chooses to react to his pain by willingly 'staying with' his neediness and vulnerability, in trusting Neoptolemus after Odysseus' prior betrayal, only to find that the two of them have been deceiving him all along. Philoctetes repeatedly uses language that indicates he feels a fatherly connection to Neoptolemus, whom he speaks of in terms that might be used of a son: through much of the play, Philoctetes calls him $\pi \alpha \hat{\imath}$, or $\tau \epsilon$ '́ $\nu o \nu$ (more than fifty-two times in all). ${ }^{19}$ It is no wonder that Philoctetes says that Neoptolemus is taking his life and that he is 'nothing, the ill-fated one ( $\left.\delta \delta \dot{v} \sigma \mu \alpha \rho)^{\prime}\right)$ ' (931; 951). Philoctetes had used his very last strength to decide to engage openly and wholeheartedly with those who promised him relief, even abasing himself in supplication, only to find that Neoptolemus' treasured words were only lies. ${ }^{20}$

At the same time, Philoctetes defines himself too much in terms of his own victimhood; his many years on the island in isolation have led to an element of bitterness and resentment easily triggered by others' actions. He understands himself too much as a passive recipient of others' actions and not enough as an active agent in the world. Philoctetes wishes to curse Neoptolemus, failing to recognize the complexity of the demands that Neoptolemus faces, in the youth's struggle to reconcile obedience to his superiors, piety, and care for Philoctetes. Still, even here, kindheartedness inherent in the man remains beneath his sense of victimhood, as he says, 'Curse you

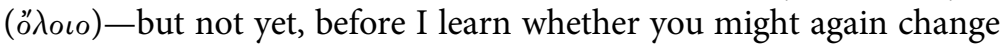
your mind ( $\gamma \nu \omega \dot{\mu} \mu \eta \nu \mu \epsilon \tau o i ́ \sigma \epsilon \iota s)$ ' (961-2). His desire for goodness in Neoptolemus, for goodness in the humanity that Neoptolemus has come to symbolize, is so strong that, even now, he awaits a change of heart on the youth's part.

Neoptolemus does not disappoint, and the young man is remarkably open in discussing his own feelings of pity, confusion, and

18 See Dio Chrystostom, Discourse 59, line 7.

19 Avery, 'Heracles, Philoctetes, Neptolemus', 285.

20 The gift of the bow bears strong resemblances to rites in a $\xi \in v^{\prime} \alpha$ (guest-host) relationship. As Belfiore has argued, the gift of the bow is reminiscent of $\xi \in v^{\prime} \alpha$ rituals that unite the two men in a form of formalized friendship. See Elizabeth Belfiore, 'Xenia in Sophocles' Philoctetes', Classical Journal 89 (2) (1993-4), 113-29. 
oppression. Philoctetes consoles him, suggesting that Neoptolemus is not a bad person, but has been taught by evil men. Here, again, we see the Sophoclean use of the language of virtue, a language that focuses on the good of character as necessarily linked to persuasion, rather than the efficacy of words as central to the good life. Philoctetes asks for the peaceful return of the bow and to be left alone. At this moment, Odysseus appears, unmoved and inflexible in his demand that both the bow and Philoctetes come with him. Philoctetes releases all his anger on Odysseus, challenging him for his reasons for abandonment (since, now that it serves his purposes, his cries and the smell of his wound are no longer reasons for separation). Philoctetes curses Odysseus with the curse that he had considered laying on Neoptolemus. Odysseus responds by saying he will then leave with the bow, and take the glory of defeating Troy for himself. Here again, Odysseus misses the point, seeing neither the bow's significance as an inheritance from the gods, nor as a bond of friendship, but simply as an instrument of war; once again, efficacy is foremost in Odysseus' mind. ${ }^{21}$ In a moment of real cowardice, Neoptolemus does not act counter to Odysseus' demands.

Philoctetes bemoans his situation, and falls into despair, as his missing bow is also his only source for food. The Chorus entreats him to join the ship before it departs, insisting, 'know that it is up to you to escape death' (1166). But the difficulty of this choice for Philoctetes is understandable, for to rejoin the ship is to accede completely to his enemy's demands, to endure further humiliation, and to again make himself even more vulnerable than he is in his isolation. To return is to resume a place in a community where other men who have treated him with so little care, most often with a concern for convenience. Philoctetes eventually expresses a wish to commit suicide, so lost is he in his sense of the inevitability of his isolation, lack of power, and his feelings of betrayal. Just as he asks for a weapon such as an axe with which to complete the deed,

\footnotetext{
21 See Biancalana, 'The Politics and Laws of Philoctetes', 162. Ryan Drake also makes the interesting point that Odysseus himself is confronted with many of the same issues that Neoptolemus faces, namely, a conflict between compassion for another and the political order. In my view, Odysseus is not as ambivalent about how to treat Philoctetes as Drake suggests. However, Drake raises significant points about the role of political order in the play, and Philoctetes' limits in recognizing the larger, divine narrative of which he forms a part. See Ryan Drake, 'Natural and Divine Orders: The Politics of Sophocles' Philoctetes', Polis 24 (2) (2007), 179-92.
} 
Neoptolemus arrives, running and out of breath, to return the bow. Instead of being given a weapon to end his own life, Philoctetes receives this sign of power and of friendship, not only restoring him the means of survival, but also restoring his honour (along with Neoptolemus' own sense of his dignity). The bow takes the place of the axe. Neoptolemus defies Odysseus, insisting that the justice of this act is more significant than any strategic advantage for Troy in owning the bow. Even when Odysseus threatens that the whole Greek army will come after the young man if he returns the bow, Neoptolemus stands firm in his belief that it is just to return it.

Here Neoptolemus stands in the same position to Philoctetes as Philoctetes once stood in relation to Herakles. Philoctetes seeks to repeat history, in asking Neoptolemus to end his suffering and pain; his initial choice of hurling himself into a volcano even repeats the motif of death by fire. ${ }^{22}$ As Kirkwood phrases it, 'Philoctetes is heir not only to the bow but to the suffering of Heracles. ${ }^{23}$ But Neoptolemus will not light the pyre, so to speak; instead, his return of the bow seeks to move Philoctetes not away from, but back to, the political community of the Greeks. The return of the bow is not a return to stasis, but rather an acknowledgement of Philoctetes' dignity in being free to choose, or not to choose, to return to fight at Troy. Thus, Neoptolemus rejects both force and forceful persuasion, in favour of a form of persuasion that acknowledges Philoctetes' human freedom. But this transition back to society is not easy for Philoctetes.

Neoptolemus not only returns the bow and arrows, but also stays the bow when Philoctetes tries to kill the approaching Odysseus. As a mediating figure, Neoptolemus here represents a mean between two extremes, advocating neither betrayal of the sort that Odysseus planned for the sake of defeating Troy, nor the simple vengeance of anger. While Neoptolemus fails to be persuaded by Odysseus' manipulations (outright humiliating Odysseus at one point; see 1292-5), Neoptolemus also insists that such a vengeful act will not bring Philoctetes any honour.

And to this extent, Neoptolemus is acknowledging the possibility of honour, of a return of social status, and of the importance of a place in the community for Philoctetes. That is, simply by saying that honour

\footnotetext{
22 See Avery, 'Heracles, Philoctetes, Neoptolemus', 295 and Gordon Kirkwood, 'Persuasion and Allusion in Sophocles' "Philoctetes"', Hermes 122 (4) (1994), 426.

23 See Kirkwood, 'Persuasion and Allusion', 426.
} 
must be a concern for Philoctetes, Neoptolemus reintroduces the possibility of an orientation to the world that is not limited to victimhood, or even the place of a supplicant. He offers the exiled man something better than being a victim, even something better than being rescued, which is to be returned to a moral status in the community where his honour is up to himself again. Such a world view also seeks to reconcile the multiple demands of nobility, friendship, piety, and political expediency, insofar as he challenges Philoctetes to willingly take up his divinely given task, not out of subservience to the Greeks who have harmed him, but out of a sense of his own responsibility for honour.

Neoptolemus then offers mature advice well beyond his years, in suggesting that Philoctetes must leave his sense of injury behind. Of course, Philoctetes' feelings are understandable, after ten years of rejection and separation, and then re-experiencing the same trauma when Odysseus returns and again betrays him. However, Neoptole-

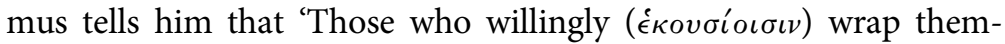
selves in their pain ( $\left.{ }^{\prime} \gamma \kappa \epsilon \iota \nu \tau \alpha \iota \beta \lambda \alpha \beta^{\prime} \beta \iota \iota\right)$, just like you, it is not right either to excuse or to feel compassion for' (1318-20). Neoptolemus cannot mean the wounded leg, for this wound was entirely accidental, and so far is incurable. Instead, the 'self-inflicted injury' that Philoctetes continues to experience is his living in accordance with his own vision of himself as a victim of both physical and emotional, even spiritual, injury. Neoptolemus lays out the facts: 'You will never find rest from this heavy sickness so long as the sun rises and sets again, unless you go to the plain of Troy freely $(\hat{\epsilon} \kappa \dot{\omega} \nu)$, meet with the sons of Asclepius there, and be relieved of this sickness (vórov)' (1330-4).

It is not that Philoctetes is inaccurate about the depth of his mistreatment by the others. The abandonment he experienced, the betrayals of being left alone on Lemnos, and then deceived in an effort only to gain his weapon, are indeed real betrayals and losses, which reflect poorly on Odysseus and those who support his manipulations. The gods have not done much to assist the wounded Philoctetes until now. But Neoptolemus' point is that Philoctetes chooses to see himself in the light of these others' visions of him: as sick, as too noisy in his cries; as useless to the war; as a victim to be pitied. His choice to reside in the place that these others have 'given' to him is no longer enforced by his physical isolation, but can be overcome by a choice to go to Troy. To do so from a position of strength requires that Philoctetes abandon his view of himself as victim, and return to 
Troy. To some extent, he must also move past his image of himself as the inheritor of Herakles' pain along with the bow, and understand his unique place in history, distinct from that of Herakles. Thus, Neoptolemus says he must return not only to be healed of the wound, but also to fight and to be 'revealed as the one who sacked' Troy (1335). Through Neoptolemus' imagined vision of who Philoctetes really is, or who he might choose to become, Philoctetes gains a new perspective on himself, and does leave his sense of himself as victim behind.

In abandoning his view of himself as victim, Philoctetes does not leave behind his vulnerability, his capacity to be wounded. Indeed, his return to society is also a return to social vulnerability. Philoctetes does not replace his vision of himself as the wounded one with a view of himself as invincible, nor does he pretend that no wrongs have been done to him. As he mulls over the question of whether to embark on the ship, the question of whether to rejoin society (realistically, his only chance to do so), he expresses his fear that his vulnerability to future harm remains: 'it's not the pain of what's bygone that bites $\left(\delta \alpha \alpha^{\prime} \nu \epsilon \iota\right)$ at me, but what it is necessary to suffer from these people, as I think about what is still to come' (1358-60). And Philoctetes is completely right; not only does return not guarantee his safety, but also, he is rather accurate about some of his comrades' deficiencies, and the evils that might befall him in rejoining their company. He ought not to be naive in supposing that betrayal of trust is not a possibility; he has experienced too much betrayal to know that it might even be likely. His deepest longing is to go not to Troy, but to retreat, and to go home... or to remain isolated in his suffering. ${ }^{24}$ To some extent, his vulnerability to society and possibility of rejection begins when he leaves Lemnos, and must participate in political, social, and military actions with those who betrayed him. That is, Philoctetes must accept the limitations of the political realm and the reality of its inherent tensions between care for virtue and the necessity of political expediency.

From all of this, Neoptolemus learns not only a general truth that the vulnerable man has a place in the community. More specifically, Neoptolemus learns another virtue, one that concerns the proper way to respond to unjust harm. As Achilles' son, Neoptolemus has in his

\footnotetext{
24 Avery, 'Heracles, Philoctetes, Neoptolemus', 284.
} 
father one model for how to respond to being harmed by others in the community (in Achilles' case, the taking of his prized Briseis). Achilles reacts first by withdrawing from that community and later by reentering the war with rage at all who encounter him. Achilles' rage is one extreme response to suffering harm unjustly. At the other extreme is Philoctetes' desired withdrawal from the body politic. Philoctetes' response to the harm suffered by the Greeks is initially to wish to return home, and to leave behind those who had abandoned him. Neoptolemus chooses to encourage a middle path in Philoctetes: neither to retreat altogether, nor to respond in anger, but rather to return to the community with a realistic, but open, sense of his role within it. Philoctetes, must learn to suffer harm at the hands of others in the proper way: not to overlook it, but also to participate in that community despite its shortcomings and the contingent nature of harm. Through the process of finding a way to bring Philoctetes back into the community, Neoptolemus himself learns that part of political virtue is to know how to suffer harm appropriately, i.e. to know that suffering from experiences that do not fit into a perfect model of justice is part of ordinary political life.

Ultimately, Neoptolemus chooses to make virtue a part of politics, against mere political efficacy. ${ }^{25}$ In contrast to the false merchant, who says that either force or persuasive $\lambda o$ yo must be used to bring Philoctetes to Troy, Neoptolemus asks about why those who deserted the man now want to bring him back: 'What longing ( $\pi$ ó $\theta o s)$ has come to them? What force and vengeance $(\nu \epsilon \in \mu \epsilon \sigma \iota s)$ from the gods, who punish evil deeds?' $(601-3)^{26}$

Neoptolemus reintroduces the question of proper moral motive as part of political solution. Still, Neoptolemus and Philoctetes alike must grow to understand that the political order will never allow for the complete moral reconciliation of the sort that Philoctetes desires, i.e. sorrow from Odysseus and the rendering of justice for past harms from the other Greeks. For the nature of politics always includes a concern with the necessary, the useful, the expedient; part of human virtue is to know how to accept such limitations in order to

${ }^{25}$ One commentator suggests that the general thrust of the Philoctetes as a whole is to defend traditional aristocratic virtue against the new democracy of Athens. Biancalana, 'The Politics and Laws of Philoctetes', 155-82.

${ }^{26}$ Biancalana, 'The Politics and Laws of Philoctetes', 166, where Biancalana notes Philoctetes' concern with $\pi$ ótos. 
continue to participate in the everyday human world. Herakles' speech serves as a reminder of the importance of larger social and political needs beyond Neoptolemus' interpersonal relationships. Neoptolemus manages to balance such concerns without abandoning the moral claims made on him, and without ignoring friendship with Philoctetes in favour of political efficacy.

Whether or not Pericles was explicitly on Sophocles' mind, Neoptolemus proves himself to be his father's son, though more moderate than Achilles himself. ${ }^{27}$ Neoptolemus insists that returning to Troy, being healed, and fighting again is really best for Philoctetes-his friend's good now being Neoptolemus' primary concern instead of the bow. Neoptolemus wishes to see Philoctetes restored to health, and to return to the war-but Philoctetes will not and can not be the same man who goes to Troy now as the one who first set out on the journey there so many years ago. Philoctetes refuses, until Herakles appears, as a deus ex machina. While some commentators have disparaged the appearance as a contrived end to the dilemma, ${ }^{28}$ Sophocles' inclusion of Herakles is entirely appropriate to Philoctetes' emergence into society again, because of the role that he had played to Herakles, and how Herakles has served as a model for him.

Herakles' speech is no doubt persuasive because of the bond that he shares with Philoctetes; as a friend, and as the original giver of the bow, his words instil trust in the wounded man in a way that Neoptolemus has not been able to do. But Herakles also fulfils the function of being two relationships for which Philoctetes longs: a father, and a caring god. Philoctetes, in his moments of pain, most often exclaims $\pi \alpha ́ \pi \pi \alpha \iota$, or even long strings of $\pi \alpha \pi \pi \alpha \pi \alpha \pi \pi \alpha \pi \alpha \hat{\imath}$ (see e.g. 754). Avery suggests that the exclamations play upon the Greek $\pi \alpha \pi \pi \alpha s$, or father. ${ }^{29}$ Herakles appears as a strong, male presence. Philoctetes has also characterized himself as 'hateful to the gods ( $\pi \iota k \rho o ̀ s ~ \theta \epsilon o \hat{\imath})^{\prime}$ ' (254) and so Herakles' presence serves as a sign that the gods, who seemingly have only injured or ignored him,

27 See Blundell, 'The Phusis of Neoptolemus', 144.

28 See, for example, Biancalana, 'The Politics and Laws of Philoctetes', 178.

29 Avery, 'Heracles, Philoctetes, Neoptolemus', 288. See also M. Roisman, Sophocles: Philoctetes, Duckworth Companions to Greek and Roman Tragedy (London: Duckworth, 2005), 108. For a different perspective, see Segal, who argues that such exclamations show how far Philoctetes has departed from the civilized world, in these moments of 'linguistic depravation': Tragedy and Civilization, 333. 
do care for his well-being. ${ }^{30}$ After all, Philoctetes wonders whether the decrees of the gods are just or not (451-2); in Herakles, he finds not only a promise of future restoration of his glory, but friendship with the gods, the presence of care. Whether or not Philoctetes' desire for justice has been fulfilled, at least his desire to know that the gods care is fulfilled in Herakles' appearance. Moreover, Philoctetes is reminded that his own story, his own life's narrative, takes on meaning in the light of a larger divine narrative; to be pious is not merely to carry out the correct sacrifices and rituals, but to understand one's self in terms of the story of the Greeks. Herakles shows Philoctetes that his life's meaning is connected to the Greek story of victory against Troy that is to be told; a narrow concept of justice as revenge will not fulfil that larger, divinely sanctioned narrative.

Philoctetes' language in assenting to the return to Troy reveals a Sophoclean sensitivity to the relational nature of the bond with

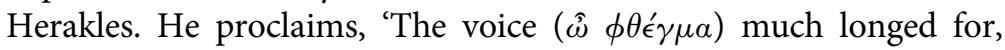
you brought, you who after a long time appeared ( $\phi a v \epsilon i s)$, I will not disobey your words ( $\mu v^{\prime} \theta$ o s) ' (1445-7). Herakles is not only important because of his words, but because of his voice, $\phi \theta \epsilon^{\prime} \gamma \mu \alpha$. That is, Herakles' voice communicates more than just words or the content of ideas; his voice communicates his presence, the friendship of the gods, to Philoctetes. $\Phi \omega \nu \eta$ ' (voice) both condemns and redeems Philoctetes; while his cries at first had led his comrades to abandon him as a curse to the gods, words from a god also restore him to his position in the community. In the way that God's self-revelation to Job in the Hebrew Bible heals Job's spiritual affliction (as well as physical ones) even as his suffering is not adequately explained, Herakles' simple presence in and of itself is healing for Philoctetes. That he also promises glory is secondary to Philoctetes' concern as to whether the gods are just and capable of friendship. Such friendship assures Philoctetes that the problem of justice, which he understands as a theological problem-'Are the gods just?'-has a positive resolution, at least in Philoctetes' concrete, lived history. Sophocles presents the question of justice as both political and theological, for both concern the possibility of friendship and community, between human beings and between the divine and the human.

${ }^{30}$ Roisman, Philoctetes, 108. See also Christopher Gill, 'Bow, Oracle, and Epiphany in Sophocles' Philoctetes', Greece and Rome 27 (2) (1980), 137-46. 
Herakles can play this role of bridging the gap between the divine and human because he is not only a god, but also a friend. His story is also especially resonant with Philoctetes' own story. Herakles recounts his own story, telling of his own deeds, labours, and eventual divine glory. However, absent from Herakles' tale is the well-known story of the intolerable pain he felt that led him to escape from life. Although the Sophoclean play does not mention the longer story of Herakles' suffering, Philoctetes references it earlier when he himself desires to die by fire: 'Oh, my son, noble one, take me and burn me with this fire which is called Lemnian. I once agreed to do this to the son of Zeus in exchange for the weapons that you are now guarding' (799-801). On some accounts, Herakles suffers because of a betrayal, as he wears a poisoned robe given to him by his wife. Both the physical suffering and sense of betrayal that Philoctetes encountered long ago in Herakles must resonate with Philoctetes. Indeed, they might well have been ideas on which he dwelt when on Lemnos alone, with Herakles' bow as his only real connection to civilization.

However, while Philoctetes has presumably seen the death of Herakles, and his own assistance in that death, as the key feature of Herakles' life, Herakles speaks not at all of these events. Instead, for Herakles, the greatest significance of his life lies in his deeds, his accomplishments, and the mutual interdependence that Neoptolemus and Philoctetes will need to have with one another if they are to capture Troy. Betrayal and suffering were a significant reality for Herakles, but in his narrative understanding of his life after its end, they are not the main events. Indeed, Philoctetes must return if he is to become an active agent, instead of a mere passive recipient of others' actions. If Philoctetes' sense of his own victimhood arises in part from being one who merely is the passive recipient of others' actions, whether just or unjust, then his return to fight at Troy is not only necessary for the Greeks, but also for himself. There alone will he find healing in becoming an active agent in the political realm.

At the same time, Herakles is insistent that the bond that Philoctetes and Neoptolemus share is crucial to their success. Like a 'pair of lions $\left(\lambda \epsilon^{\prime} O \nu \tau \epsilon\right)$ ', they will have to guard one another (1436). But the source of their close bond stems from this mutual vulnerability that they have experienced on Lemnos: not only Philoctetes' multiple vulnerabilities, but also Neoptolemus' willingness to expose his shame, his moral vulnerability and weakness, to Philoctetes, and to seek reparation rather than running away from its possibility. 
Philoctetes willingly rejoins the political community with openness to the reality of his vulnerability within it. Just as importantly, Neoptolemus rejoins that community with an understanding of the vulnerable one as he who possesses dignity and who is fundamental to the success of the community. We cannot also forget that Herakles warns against impiety; and in that tradition, Neoptolemus will impiously kill Priam on the altar at Troy. Sophocles is not naive about the difficulty, the fragility of care for the vulnerable, and there is a dark edge that accompanies this mostly happy ending. ${ }^{31}$ Nonetheless, such an event lies outside the scope of the play's action. Instead, the play ends with an affirmation of inclusion of the wounded one and the promise of his restoration. At the moment of their departure from Lemnos, we can see in Philoctetes and in Neoptolemus that each has undertaken a journey made possible only by the presence of the other; each has grown in new directions previously thought impossible. So while their destination is Troy and a new battle, the Chorus' words of homecoming are nonetheless appropriate, as they end the play, saying,

Let all of us depart together when we have prayed to the sea nymphs

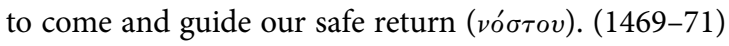

31 Blundell, 'The Phusis of Neoptolemus', 146; Kirkwood, 'Persuasion and Allusion', 428; Rose, 'Teachings of the Sophists', 102. 
This is an open access version of the publication distributed under the terms of the Creative Commons AttributionNonCommercial-NoDerivs licence (http://creativecommons.org/licenses/by-nc-nd/3.0/), which permits non-commercial reproduction and distribution of the work, in any medium, provided the original work is not altered or transformed in any way, and that the work is properly cited. For commercial re-use, please contact academic.permissions@oup.com 


\section{4 \\ Wounding and Wisdom in Plato's Gorgias}

Any discussion of vulnerability in Greek thinking ought to consider the difficult case of Plato. A variety of commentators have argued that Plato is particularly insensitive to vulnerability and human imperfection. Martha Nussbaum, for example, sets out the thesis that in the dialogues, Plato is offering an example of 'anti-tragic theater'. ${ }^{1}$ Nussbaum argues that Plato writes in a theatrical genre, the philosophical dialogue, in a way that deliberately minimizes the engagement of emotions, thus separating himself from the tragedians who encourage such feelings. ${ }^{2}$ In her view, works such as the Republic diminish the affective realm and even attack the goodness of ordinary life in favour of a more removed, rational order. Similarly, Charles Griswold has argued that the Republic asserts the goodness of the perfection of the forms at the expense of diminishing ordinary, imperfect human life; the world inside the cave is undesirable on the Platonic account, yet where most people actually live their lives. ${ }^{3}$ Against this view, others argue that Plato takes up an outright tragic view, for example, identifying a certain scepticism in Platonic thought with respect to the ability of reason to achieve the ends for which it strives. ${ }^{4}$ Socrates

${ }^{1}$ Martha Nussbaum, The Fragility of Goodness: Luck and Ethics in Greek Tragedy and Philosophy, rev. edn. (Cambridge: Cambridge University Press, 1986), 122-35.

${ }^{2}$ Nussbaum, The Fragility of Goodness, 132.

3 Charles Griswold, too, interprets the Republic to be opposed to a kind of care for the ordinary in favour of a longing for something not simply better, but best. See Griswold, 'Longing for the Best: Plato on Reconciliation with Imperfection', Arion 11 (2003), 101-36.

${ }^{4}$ See, notably, David Roochnik's work Beautiful City: The Dialectical Character of Plato's Republic (Ithaca, NY: Cornell University Press, 2003) and The Tragedy of Reason: Toward a Platonic Conception of Logos (London: Routledge, 1991). 
posits an idealistic account of excellence, but does not argue that he has achieved it or that human beings can do so.

Indeed, the dialogues offer philosophy through the dialogue form as an alternative both to the tragic form and to the work of other intellectuals of Plato's time (such as the sophists, but also other politically minded thinkers, including Isocrates). ${ }^{5}$ The dialogue form draws upon the tragic genre (and other genres such as the epic and even poetic), while also offering criticisms of the shortcomings of those narrative forms. ${ }^{6}$ At the same time, however, Plato continues within a tradition of writing in dramatic form, not in treatises. His works, like those of tragedy, comedy, and epic, contain multiple voices and perspectives as part of their articulation of ideas. Platonic dialogues rely upon narrative not only as dramatic setting for abstract ideas, but also include dramatic action as part of the working out of philosophical activity. Plato presents philosophy as a way of living, and not only a way of thinking. Moreover, we find the dialogues themselves concerned with the question of vulnerability within some of their internal narratives.

This chapter examines one such narrative: the myth at the end of Plato's Gorgias that features as its central image a wounded and unjust man. In that myth, Plato sets forth attentiveness to human vulnerability as central both to philosophical living and to the political art. While he does prescribe the virtues as a means for overcoming a degree of vulnerability to harm, Socrates also recognizes a limit to the extent to which such overcoming of imperfection is possible. Socrates' continued willingness to seek out and to engage others in their imperfection through philosophical conversation reflects a care for human imperfection and frailty. Just as Greek medicine understood itself to be a limited, although valuable, therapeutic, Socratic and Platonic philosophy seeks to meet and to act as a kind of $\theta \epsilon \rho \alpha \pi \epsilon^{\prime} \alpha$ for others in their imperfection. In this chapter, I first examine the notion of wounding in the myth of the Gorgias, and then explore links between Greek medicine and philosophy for how

\footnotetext{
${ }^{5}$ See my earlier work on distinguishing between the rhetoric of sophistry and Platonic philosophy in Marina McCoy, Plato on the Rhetoric of Philosophers and Sophists (Cambridge: Cambridge University Press, 2007).

6 See Andrea Nightingale, Genres in Dialogue: Plato and the Construct of Philosophy (Cambridge: Cambridge University Press, 2000).
} 
their relation helps us better to understand Socrates' care for his interlocutors in their vulnerability.

The myth that ends Plato's Gorgias is one of the strangest in the Platonic corpus, both for its content and the context in which it arises. Socrates and Callicles have been arguing over whether the just man or the unjust man lives the happiest life, and rather than ending either with a resolution of the problem, or even ordinary ajmopía, their conversation has degenerated into total silence on Callicles' side. Shortly before the myth, Socrates takes both his and Callicles' 'part' in the conversation before an angry, disgruntled Callicles-who is understandably upset after Socrates' comparison of Callicles' ideal

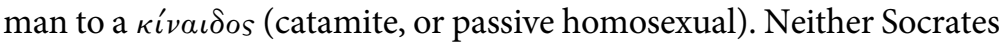
nor Callicles seems to be a model of good sportsmanship by the end of their conversation. Yet, Socrates feels compelled not to rest in silence, but insists on telling his myth of judgement. The myth is a harsh indictment of the unjust man and, by implication, also of Callicles. However harsh it is, Socrates' myth nonetheless shows a deep sensitivity to the vulnerability of the human condition.

The question of vulnerability is also of interest, insofar as Socrates' reasoned arguments with Callicles fail to persuade; we might then also see the myth about judgement as an alternative philosophical response in light of the limits of reason. Indeed, Socrates insists that his tale is both a $\mu \hat{v} \theta 0 s$ and a $\lambda o ́ \gamma o s ;$ the two terms are not necessarily exclusive: 'Give ear then-as they put it-to a very fine account. You'll think that it's a mere tale $(\mu \hat{v} \theta o \nu)$, I believe, although I think it's an account ( $\lambda$ ó $\left.^{\prime} \sigma \nu\right)$, for what I'm about to say I will tell you as true $(\dot{\alpha} \lambda \eta \theta \hat{\eta})^{\prime}$ (Gorgias 523a1-3). ${ }^{7}$ By 'true', Socrates cannot mean a literal account of what happens after death, for we know from both the Apology and Phaedo that Socrates repeatedly asserts that he does not know the exact nature of what awaits him after death. Instead, Socrates seems to think that a story is better suited to convey an idea to his audience about a reality that is at least somewhat unknowable. Precisely because the literal details of what follows death are unknown, a $\mu \hat{v} \theta 0 s$ is self-disclosive about its limits: it is 'only a story', yet its images evoke its audience's imagination, feelings, and desires where reason by necessity cannot go. As such, a $\mu \hat{v} \theta$ os can still speak about the meaning of death as a human limit, and how that limit

\footnotetext{
7 Translations of the Gorgias throughout this chapter are from Plato, Gorgias, trans. Donald Zeyl (Cambridge, Mass.: Hackett, 1986).
} 
ought to inform human life. Narratives such as the myth of judgement in the Gorgias serve as important reminders that the enterprise of Socratic philosophy is best understood as an exploration of human weakness, as well as of human strength. The myth of judgement exhibits such limit in its content, as it features a man who is wounded, who bears scars in his soul.

However, Socrates' move to a mythological form also suggests a limit being displayed by this form of $\lambda$ ó $\gamma o s$ : myth expresses a form of understanding that admits its own limits in light of a reality (e.g. death) beyond full comprehension, but one which profoundly affects the whole of the soul while yet it lives. As Kathryn Morgan has argued, the tensions created by movement in and out of myths, from argument to myth and back again, force an audience to change perspective. ${ }^{8}$ The Gorgias' final myth seems to intend a change of perspective, in asking Callicles to rethink his understanding of the large context of his choices and values. The particular imagery of the myth and its emphasis upon the language of health, woundedness, and judgement seems especially well suited for use with Callicles, with whom Socrates has had little success thus far in argument. The images of the myth re-contextualize some of Callicles' aims and values into a larger, cosmic scheme.

Socrates begins his own story with a reference to the Homeric division of the cosmos among the gods Zeus, Poseidon, and Hades, but then links that division to a story of judgement in Hades' realm. Under the reign of Cronos, he says, the souls of those who were about to die were judged while still alive, clothed, and able to bring forth family and friends as witnesses to their worthiness for heaven. ${ }^{9}$ However, their clothing disguised their true natures, insofar as clothing implied wealth, power, or beauty that veiled the true soul beneath. It was not only the souls of the dead that were veiled, but also the souls of the judges: even the judges were 'awed' by the souls

\footnotetext{
${ }^{8}$ Kathryn A. Morgan, Myth and Philosophy from the Presocratics to Plato (Cambridge: Cambridge University Press, 2000), 6.

9 See Iliad XV. $187 \mathrm{ff}$.
} 
because they, too, were still alive when rendering judgement, and 'they themselves too [had] their clothes on when judging; their eyes and ears and their whole bodies [were] interposed as a veil ( these living judges lacked not only knowledge of those whom they judged, but also accurate knowledge of their own condition. This lack of self-knowledge, as well as knowledge of the other, rendered their judgements unjust, such that many who ought to have gone to the heavens were sent to Hades and vice versa.

To correct for these judicial mistakes, Zeus devises a new system of judgement. He announces to Prometheus:

What we must do first, he said, is to stop them from knowing their death

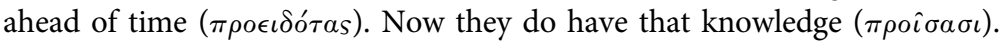
This is something that Prometheus has already been told to put a stop to. Next, they must be judged when they're stripped naked ( $\gamma v \mu \nu$ ò̀s) of all these things, for they should be judged when they're dead ( $\tau \in \theta \nu \epsilon \hat{\omega} \tau a s)$. The judge, too, should be naked ( $\gamma v \mu \nu \grave{\nu} \nu$ ) and dead $(\tau \in \theta \nu \in \hat{\omega} \tau \alpha)$, and with only his soul he should study only the soul of each person immediately upon his death, when he's isolated from all his kinsmen and has left behind on earth all that

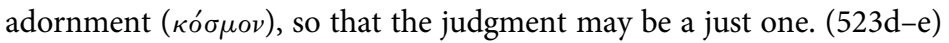

The state of judges as dead and naked is a most curious feature of the myth. While the nakedness of the man who is to be judged is expected, that the judges themselves must be stripped and dead is striking (especially given the strong parallelism of language in the passage above with respect to the judge and the one being judged).

If Socrates' main concern with a fair judgement is that the truth about a human being be public and 'out in the light of day', then the only one who is fit to render such a judgement would be another soul who himself has undergone the process of being 'stripped down' to his bare soul, the soul that understands what it is like to be in the position of being judged and made vulnerable to the judgement of another human being. He best understands the complexity of the human condition: the life of the person before judgement who lacks foreknowledge of death and who has had the experience of being stripped of the external goods that were once significant to him. The judges themselves must be dead because they alone comprehend both the finality of death and the difficulty of living a life in which the day of our death and the judgement of our lives' goodness is fundamentally uncertain. 
Socrates makes clear that nakedness of the judge's soul proves to be a key to just judgement because only then will his own perceptions also be freed of the same reliance of social status and his own connections through kin, wealth, and other temporary 'cloaks' of the soul. Additionally, as one who is himself naked, but was once clothed, he is aware of the difference in himself between the self that he projected in the social world and the true self that lay veiled beneath. To this extent, he also has the capacity to see the true self in the other and to sympathize with the human condition of being stripped of such external trappings. That is, it seems that the selfknowledge and authenticity of the judge's encounter with his own state of soul, as well as his past experience as part of the human social world, prepare him to see another accurately and sympathetically.

One implication of the myth is that we are not especially accurate judges of our own souls while still engaged in the process of living. In life, we might often have the experience that we understand aspects of another person that the other fails to see about himself or herself; thus, it is almost a common piece of wisdom that our friends often know us even better than we know ourselves. In death, too, the naked souls only come to see themselves through the eyes of another who can show or reveal their souls and their real conditions to themselves. As when, in the Phaedrus, Socrates suggests that one soul can come better to know itself as if in a mirror through interaction with a lover (Phaedrus 255d), the judges here reflect back to the judged man his true condition. That is, Socrates implies that our self-knowledge in life is rarely accurate, and that to come to a greater truth about oneself requires others. But a paradox of death is that it comes at a time not of our own choosing or foreknowledge, and yet, until the moment of death, it is not fully possible to make a fair judgement about oneself.

The souls of the dead are judged and sent to one of two places, either to Tartarus or to the Isles of the Blessed, for punishment or for reward. Initially, Socrates offers as the divine plan a total bifurcation of the world into good and evil: either one has lived the life of the non-meddlesome philosopher in justice and holiness, and so is rewarded with 'perfect happiness', or one has lived impiously and so is punished with a vengeance $(526 \mathrm{~b}-\mathrm{c})$. Missing from this picture of the human being is any sense of the 'in between' nature of the human being familiar from the Symposium and Phaedrus. If we look at many of Socrates' interlocutors, too, we find that they are more often than not 'in between' people, who might care deeply about 
courage, as does Laches, but not fully understand its nature. Some want to change their deepest life's commitments, as does Alcibiades-at least in the presence of Socrates-but find themselves unable to do so.

Moreover, this myth reveals that we are also capable of self-wounding: some moral choices leave us deeply wounded with resulting scars that must be lived with or somehow integrated, or at least accommodated. Socrates' interlocutors are at times sympathetic to Plato's reading audience because we can, as readers, identify with them. We can understand not only why they might arrive at their philosophical positions (or at least unphilosophical beliefs), but also sometimes identify with their thumotic or appetitive reactions, or shortcomings of character. When Alcibiades in the Symposium presents his painstakingly honest situation as one who is always trapped in his political ambition, desires to be free of it, but finds himself never quite able to escape, he is sympathetic because his situation is human. Socrates, too, seems to have understood that Alcibiades was a wounded soul, looking to escape himself in his current state; where others might see a mutilator of the hermai or a betrayer (or hero) of politics, Socrates sees the inner, wounded man.

So it is at first unexpected that the souls in this myth are either destined for pure bliss or total suffering. However, as Fussi has argued, one of the key vulnerabilities of the human being displayed in this myth is the finality of death. ${ }^{10}$ While the myth speaks of a time when human beings once knew the day of their deaths and so could prepare for judgement, Zeus removed our ability to know the moment at which each one of us will die. Death is final with reference to our ability to change our characters. The 'in betweenness' of human nature that is central to our self-knowledge while alive ceases at the moment of death, when suddenly others can look back at a life no longer in motion and make an assessment, a judgement, of how that life was lived. Just as Aristotle in the Nicomachean Ethics points to the difficulty of assessing the happiness of an entire life until that life is over (N. Ethics 1100a1-6) - the least valuable time for a moral actor himself-Socrates' myth points to the difficulty of assessing a whole life accurately from the point of view within the development of that life. Human beings are vulnerable not only to the facticity of death, i.e. death as the termination of life, but also to the way in which the overall shape or pattern of our lives as a whole is unknown to us before death. Even if a person of virtue can somehow regard himself

10 Alessandra Fussi, 'The Myth of the Last Judgment in the Gorgias', Review of Metaphysics 5 (3) (2001), 534-5.

This is an open access version of the publication distributed under the terms of the Creative Commons AttributionNonCommercial-NoDerivs licence (http://creativecommons.org/licenses/by-nc-nd/3.0/), which permits non-commercial reproduction and distribution of the work, in any medium, provided the original work is not altered or transformed in any way, and that the work is properly cited. For commercial re-use, please contact academic.permissions@oup.com 
as a just person now - and Socrates often shows his interlocutors their lack of accuracy in self-knowledge-Socrates in the Apology presents the human being as in a constant 'race' against injustice, when he says that 'injustice is swifter than death' (Apology 39a). Added to the vulnerability of judgement itself is a kind of vulnerability of selfknowledge, in which we are at least partially ignorant of our own just or unjust state at precisely the time that we could change our state. Last, most human beings avoid thinking of death in the midst of life. At the purely phenomenological level, death often seems unexpected; despite abstract knowledge of my own mortality, it remains somewhat surprising that 'I will die.' Yet, once we are fully aware of the just judgement of our souls after death, Socrates implies, it is too late to change that state.

For Socrates, this limit is no cause for cynicism, but rather a call to devote oneself even more fully to the practice of virtue, rather than relying upon the social 'clothing' of wealth, status, and appearance as a place in which to hide our true selves from others and even from ourselves. In other words, if one is to come to see the truth about oneself, Socrates implies, one must be willing to be vulnerable to judgement: not the judgements of those who rely upon conventional measures of political and social success, but another who possesses some degree of self-knowledge. To this extent, it might be possible before death to remove some of the obstacles to self-knowledge. That is, if the myth suggests that status, wealth, honour, and power are ways that we 'cloak' ourselves not only from others, but also from ourselves, then by removing these 'cloaks' while alive, we might become more aware of our true selves and our own limitations. Such an approach also makes room for a constructive response to the results of past mistakes, or self-wounding.

Plato presents us with the possibility of one who can judge and awaken another while still alive precisely because of his knowledge of his own nakedness: Socrates. In the Apology, Socrates professes knowledge of his own ignorance (Apology 21d). He is aware of the weakness of his own soul as a human being and does not project false strength, as do the politicians, poets, and craftsmen of the Apology, or Callicles, Polus, and Gorgias do in the Gorgias. Within the Gorgias, Socrates claims that he is a man who enjoys being refuted even more than he enjoys refuting (Gorgias 458a). He takes pleasure in the recognition of his own vulnerability, and appreciates whatever judges in his life have found a way to expose his vulnerability and lack to 
him. As such, the character serves as an idealized exemplar of a soul still living who has the capacity to awaken another soul to its true state precisely because he is more naked to himself, so to speak, than most souls. The final section of the Symposium, in which Alcibiades describes his feelings of doubting and questioning the value of his devotion to conventional political goods when in the presence of Socrates, is a well-known case of such an awakening produced by Socrates, even while conceding that it was never sufficient to transform Alcibiades' life (Symposium 215a-222b). Socrates not only chooses the life of the often-barefoot man unconcerned with clothing, reputation, or wealth. In the Gorgias he even speaks about his own death and the false judgement that he might receive, were he ever to be brought to court: 'And because I'm not willing to do those clever things you recommend, I won't know what to say in court. And the same account I applied to Polus comes back to me. For I'll be judged the way a doctor would be judged by a jury of children if a pastry chef were to bring accusations against him' (521e). Socrates adds that he would not be surprised if he were put to death, through the false judgements of those who lack the proper means by which to judge.

Socrates anticipates a false judgement of him, one that parallels the first mode of judgement in the myth, based on the outward appearance, rather than the inward truth of his soul, by judges who lack accurate self-knowledge and judge through the cloaks of their own false opinions of themselves and others. Here in the Gorgias, Socrates is prophetic. To some extent, he escapes the ignorance of most souls who know little of themselves or their eventual deaths. This knowing Socrates is, of course, itself a Platonic invention. That is, the Platonic dialogue is itself a $\mu \hat{v} \theta 0 s$ of sorts, in presenting an idealized Socrates who alludes directly to the cause of his eventual death. As one who is more aware than most of his own finitude, his own ignorance, Socrates at times is able to uncover and uncloak it in others. Uncloaking Callicles to himself is also the purpose of this story, this $\mu \hat{v} \theta o s$.

\section{II}

The myth seeks to awaken Callicles' moral imagination, or at least the imagination of others present to the conversation, about how to understand human life and justice in terms of a larger whole. The 
story can be understood as an effort to reconfigure Callicles' view of himself in relation to the world in the light of the context of human vulnerability and mortality, through calling to Callicles' imagination. Socrates' appeal to the 'moral imagination' works differently from, for example, a logical refutation of a series of premisses, insofar as his story engages our emotions, as well as our intellects. If one looks at the overall shape of the Gorgias, one finds that logical refutations prove to be rather ineffective with Gorgias, Polus, and Callicles alike. When Gorgias is tripped up and claims in turn both that some orators use rhetoric unjustly and that an orator will never want to do what is unjust, Polus interrupts the conversation to tell Socrates that he has only forced Gorgias into a 'little inconsistency' and that Socrates cannot really believe what he seems to be arguing. When Socrates shows Callicles that, by his own premisses, doing what's unjust is more shameful, not only by law, but also by nature, Callicles accuses him of engaging in eristics and 'making hay out of someone's tripping on a phrase' (489c). While it would be easy to assume that Callicles simply does not care for the truth, or is eager to escape verbal defeat for the sake of his reputation, it also seems that Callicles really believes in his stated opinions. A purely rational engagement with the possible inconsistencies within his view is not enough to move Callicles to an entirely different view of the world. ${ }^{11}$

Most of our moral beliefs engage our souls as a whole, and not only our reason. Shame, for example, can be a powerful motivator. Tarnopolsky offers a thoughtful and careful analysis of two forms of shame in the Gorgias: a view of shame that is solely oriented toward avoiding having one's self-image punctured, and a receptive form of shame. ${ }^{12}$ Callicles wishes to avoid criticism of his identity or exposure of his inadequacies. Thus, Socrates' arguments anger him immensely. However, Socrates' aim is not discomfort for the sake of destroying Callicles' image, but rather to show Callicles the limits of his selfimage and to move him toward openness to consider significant change in his ethical norms. ${ }^{13}$ Socrates' shaming of Callicles takes place out of a respect for Callicles, although Callicles certainly does

\footnotetext{
11 See my more extensive argument for this point in McCoy, Rhetoric of Philosophers and Sophists, chapter 4.

12 Christina Tarnopolsky, Prudes, Perverts, and Tyrants: Plato's Gorgias and the Art of Shame (Cambridge: Cambridge University Press, 2010), especially 18-21.

13 Tarnopolsky, Prudes, Perverts, 19.
} 
not perceive it that way. Images such as the final myth of the Gorgias engage Callicles' shame, not only his reason.

In addition, Socrates' turn to the use of images, such as a leaky jar or a кivaıdos, and Callicles' similar offering of the image of a corpse, are attempts to reframe the world views of one another by re-contextualizing part within a whole. For example, hearing of a just soul as akin to a corpse, for example, might cause fear or anxiety of a wasted life that never really lived. Instead of only picturing a soul that restrains its appetites, Callicles' image reframes the 'moderate' soul as one who has never lived fully, insofar as this soul seems to be a milder version of a corpse who no longer desires anything at all. As part of the presumed unpleasantness of anticipating death is the loss of desire and fulfilment, Callicles leads his listeners to picture the just soul as one that is 'dying prematurely', so to speak. The effect of such an image includes an emotional response to the thought of losing oneself in death, and not only an intellectual one.

Similarly, Socrates' use of his own images in response to Callicles' image of the corpse also allows us to think differently about the context of Callicles' claims about the appetitive life. ${ }^{14}$ Socrates responds to Callicles' claim that the best life is one in which one's appetites are enlarged and left undisciplined, so that they might be filled over and over again (491e-493d). In return, Socrates offers the image of a leaky jar, fed by a leaky sieve, as a good image of Callicles' ideal soul. Socrates takes up and reincorporates Callicles' image of endless 'emptying and filling', which might have a certain appetitive appeal, in terms of a defective nature. It reframes the reason behind the unjust man's need for constant 'refilling': the soul of large and endless appetites is defective. While Callicles wishes to draw a sharp line between vómos and $\phi \dot{v} \sigma \iota s$, Socrates' image of the leaky jar presents the difficulty with such absolute separation by tying the vómos and the $\phi \dot{v} \sigma \iota s$ of the unjust man back together again. A leaky jar is judged as not useful and therefore bad because of its failure to fulfil nature: it fails to perform its task because it fails to be itself, that is, it has a nature to contain and to hold, and fails to live up to that standard.

\footnotetext{
14 Whether the final narrative is effective with Callicles is unknown, as we do not hear Callicles' own response. However, Morgan thoughtfully suggests that Callicles' expressed disdain for $\mu \hat{v} \theta$ os earlier in the dialogues diminishes his respect for this mode of discourse as well. See Morgan, Myth and Philosophy, 190-1. Still, the use of imagery and myth remains important for Plato's own audience.
} 
The soul, too, has a function or purpose, and to be itself in an ordered manner, it must contain its appetites; but this same ability to fulfil its nature (in part through ordered containment) is also what makes it socially useful. Socrates has already argued for the importance of a nature that acts in accordance with vómos, but the argument fails to persuade Callicles at the level of abstraction. Imagery, however, engages the imaginations of those who listen, as we might feel a natural distaste if we have encountered, for example, a leaky jar in a cabinet of food, or spoiled food inside such a jar. The image draws together a considered rational assessment with a proper appetitive distaste for injustice.

The myth of judgement adds further to the recontextualizing of the unjust man's soul in a larger, cosmic context. Callicles speaks of the ability to indulge in pleasure as the mark of the free man, and sees the world of politics as the largest context of human affairs. In contrast, Socrates presents the larger cosmic picture as one in which the unjust man is scourged and unfree, subject to punishment by another whose judgement is born out of that wider context. Earlier, Socrates had also compared the unjust man to a кivaıdos. For the Athenians, a кivaıbos was understood as one who, on an Ancient Greek understanding of male sexuality, has feminized himself through allowing himself to be penetrated. ${ }^{15}$ A typical punishment was to lose one's rights as a citizen, for example, the right to vote in the Assembly. Here, Socrates re-asserts a link between licentiousness and a lack of freedom through appeal to the example of a disempowered man. Thus, he draws upon Callicles' own respect for free democratic leaders, and suggests an inconsistency between Callicles' hedonism and view of free citizenship. ${ }^{16}$

The myth of judgement also emphasizes the unjust soul as one that lacks freedom. In claiming that the soul permanently takes on the marks of its past unjust actions-just as the body does if the latter is wounded, whipped, or scarred-Socrates re-unifies vó $\mu$ os and $\phi \dot{v} \sigma \iota s$ :

And I think that the same thing, therefore, holds true also for the soul, Callicles. All that's in the body is evident after it has been stripped naked of the body, both things that are natural to it and things that have happened to

${ }^{15}$ See John Winkler, 'Laying Down the Law: The Oversight of Men's Sexual Behavior in Classical Athens', in Froma Zeitlin, John J. Winkler, and David Halperin (eds.), Before Sexuality (Princeton: Princeton University Press, 1991), 171-201.

16 See also Tarnopolsky, Prudes, Perverts, 84. 
it, things that the person came to have in his soul as the result of each objective. (524d)

Socrates goes on to say that each of the souls' actions has been 'stamped' upon his soul. A character, a $\chi \alpha \rho \alpha \kappa \tau \eta \dot{p}$, is literally an impression: these souls are 'impressed' with their own deeds. But the scarred soul of the myth of judgement is not one harmed by others; instead, he finds that he is scarred as the result of his own actions. Socrates' myth asks Callicles to imagine the possibility that he, too, if uncovered, would be unfree not only as the result of others' judgements (i.e. a vónos for which Callicles has displayed a kind of contempt), but also as result of discovering his own self-inflicted wounds. In other words, eventually Callicles will have to face his own judgement of himself in his real condition.

We might return to the Philoctetes for a moment and recall Odysseus' insistence that persuasion (even false persuasion) is the best route for resolving problems. When Neoptolemus hesitates to lie to Philoctetes, preferring even to capture him in battle with an open purpose over deceitful capture in words, Odysseus tells him, 'I was young, too, once and then I had a tongue very inactive and a doing hand. Now as I go forth to the test, I see that everywhere among the race of men it is the tongue that wins and not the deeds' (Philoctetes 96-9). Here Odysseus refers to judgements as being made primarily in reference to words and not deeds.

Socrates' vision in the myth of judgement stands in direct opposition to that of Odysseus. While he is famously a lover of $\lambda$ ó $\gamma o \iota$ and teller of $\mu \hat{v} \theta o \iota$, Socrates' myth of the judgement is finally focused on deeds and not words. It is not the words, but the actions of the person that leave a mark on his own soul. In the myth, the judges silently look at the soul, who it has become through its activity in the world.

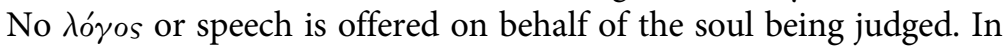
the Gorgias, after Callicles has claimed that Socrates had better exercise care in how he speaks, or else he might be dragged away to be judged and find himself without means to defend himself, Socrates admits that this is true, but it is not what most concerns him. Indeed, if Socrates were to be judged as the man in the myth is judged, he would not even be asked to speak. Instead the truth of his soul would show forth, when uncovered, his past deeds. The myth renders concrete the meaning of $\alpha \lambda \epsilon \theta \epsilon^{\prime} \alpha$ (truth) as an 'uncovering', in the soul's being uncovered for judgement. 
The myth also suggests a reason for why one might judge another unjustly: the judges, while still alive, lack a sense of their own vulnerability and nakedness. That is, they do not see Socrates first as another soul, akin to their own, destined for death. Socrates' main fear is not a fear of death, but instead of living badly, i.e. being an unjust man-as we see in the Apology when he compares himself to Achilles and argues that he has cared only for justice and not for the length of his own life (Apology 28d-e). To this extent, Socrates might appear to be invulnerable in his utter confidence in the courtroom. However, Plato's Socrates spent so much of his time among non-philosophers, even those destined for the history books as unjust men (think of Charmides and Critias). He had a deep understanding and appreciation of the vulnerability of human nature to injustice, as well as to judgement. Like the judges of the myth, he was well suited to question and to seek to expose others' inadequacies to themselves, even while alive.

To this extent, I would argue that Socrates' myth is an expansion of his earlier claim to Callicles that a good political leader must not only imitate, but also be like, those whom he leads (510d). A good judge is one who is aware of his own limit and vulnerability as a human being. Just as the judges can only judge other souls in a state of nakedness and exposure, Socrates can assess others well because he keeps in mind his own vulnerability and exposure to danger. This is part of what Socrates intends to communicate when he states that he is the only one who puts his hand to the political art (521d). Socrates is not a politician in the conventional sense, but he displays a remarkable ability to understand the human soul and all of its shortcomings, and in that sense is a deeply political man.

We might then also see the myth of judgement as a direct reply to Callicles' assertion that philosophy is a useless and apolitical enterprise, for Callicles says to Socrates that he feels a brotherly feeling for Socrates, as Zethus did for Amphion, and so warns him that too much philosophy distracts from the real work of human life. Callicles cautions him:

As it is, if someone got hold of you or anyone else like you and took you off to prison on the charge that you're doing something unjust when in fact you aren't, you can know that you wouldn't have any use for yourself. You'd get dizzy, your mouth would hang open and you wouldn't know what to say. You'd come up for trial and face some no good wretch of an accuser and be put to death, if death is what he'd want to condemn you to. (Gorgias 486a) 
Plato, of course, writes this after Socrates' trial and death, and so might be understood as offering one possible criticism of Socrates' philosophical practice, as an activity that made him too vulnerable, open to the unjust manipulation of others, and unprepared to defend himself. ${ }^{17}$ Callicles' criticism of philosophy is not without merit: Socrates' practice and especially his unwillingness to be more 'politic' in his speaking to others renders him vulnerable to the judgement of the city.

But the Apology makes clear that Socrates' work is not to defend himself at all costs, but rather to work for the care of souls. Socrates even speaks of the importance of maintaining an epistemic vulnerability. He claims that the one practice that he loves more than refuting another is to be refuted himself. The reason he offers is that it is 'a greater good to be rid of the greatest evil from oneself than to rid someone else of it' (458a). Callicles is disturbed by such an idea, as when he objects to Socrates' refutation of Polus with the exclamation that if Socrates is right that it is better to suffer an injustice than to commit one, then all of the world will be 'overturned' ( $\left.{ }^{\prime} \nu \alpha \tau \epsilon \tau \rho \alpha \mu \mu \epsilon^{\prime} \nu o s ; 481 c\right)$. Gorgias, too, sees rhetoric as the source of freedom for the city and for those within a city who practise rhetoric, and again this is related back to a sense of safety found in careful control and planning of words and speeches. But Socrates sees $\lambda$ ó ${ }^{\prime}$ s not always as the source of comfort but sometimes also of discomfort. $\mathrm{He}$ does not use words to flatter others, but often to upset or to overturn their ideas, and to push them to greater self-knowledge, especially knowledge of their limits. ${ }^{18}$ Fussi helpfully connects vulnerability in this myth also to another basic form of epistemic vulnerability: the recognition that truth is independent of the thinker.

17 For example, James Arieti, 'Plato's Philosophical Antiope: The Gorgias in Plato's Dialogues', in Gerald Press (ed.), Plato's Dialogues: New Studies and Interpretations (Lanham, Md.: Rowman and Littlefield, 1993), 197-214.

18 Tarnopolsky has recently argued that the nature of judgement in the myth parallels Socratic elenchus in a number of ways. For example, Socrates' demand to Polus that he alone defend his view, and not call on the testimony of others (Gorgias 472c), is akin to the just man standing alone in judgement. The feelings of the wounded man under judgement parallel the experience of being shamed by Socrates. See Tarnpolsky, Prudes, Perverts, 120-6. Morgan also argues that when Socrates moves between different types of discourse, he problematizes the use of any one, thus in his rhetorical style demonstrating a critical dimension; see Morgan, Myth and Philosophy, 15-45. See also McCoy, Philosophers and Sophists, on Socrates' rhetoric with Callicles in the Gorgias, especially 107-9. 
I cannot entirely create my own truth, nor even can a community create its own truth, without eventually bumping up against something that reminds me that some aspect of my 'truth' is a mere construction. Of course, such events occur often as experience widens, which is why we often find our understandings of the world overturned, shattered, upset, and must reconfigure them: because there is a truth that reminds us that we have not created it. We cannot long force the world into categories that we alone create so long as there are others in the world with whom we willingly interact. As Fussi says, those trapped in the age of Cronos are 'prey to appearance' because 'truth like death, is beyond their control'. ${ }^{19}$ We need others to help us to find the truth, but they are not its creators, but more like witnesses who assist us. ${ }^{20}$ To this extent, we are all vulnerable to the truth, and vulnerable to the difficulties that accompany our own gradual realization of our limitedness when the truth bumps up against our own constructed understandings of what we think is, or ought to be.

The myth, in other words, begins with the idea that human woundedness, or openness to wound, is one of the most basic facts or truths about our own existence. These things, Socrates says, although a myth, are also true (523a). These are facts: the human being is a mortal, is going to die, will be stripped of clothing and status and security. All of these parts of the myth are 'facts', but for Socrates, there is something more important than even this: the ultimate vulnerability is that we can harm ourselves through our own unjust actions. Such actions have significance for the whole community, for they become an example to others, either of how to be or how not to be. Others will judge and evaluate us by our actions. Socrates, then, also objects to Callicles' denigration of vónos (law or custom) as mere convention, for according to Socrates, even what a soul does to itself is already inextricably interwoven with the life of the larger community, who witness something which a person stands for. In other words, even my own vulnerability is already a political fact, as well as an individual one.

19 Fussi, 'The Myth of the Last Judgment', 536.

${ }^{20}$ Fussi, 'The Myth of the Last Judgment', 537. 
The political problem of woundedness also arises more problematically in the Republic, when Socrates argues that a perfectly just city will not offer medical treatment to those who are chronically ill, if they are beyond cure. Certainly, such a view is opposed to the kind of outlook presented in the Philoctetes, where Philoctetes' abandonment as a result of his wounds is problematized and criticized. In the Republic, Socrates especially cautions against the treatment of illness when such treatment becomes the primary activity of one's life. He cites the case of Herodicus, a gymnastics master who was so ill that he treated a chronic illness with a regimen of gymnastics and medicine that left him no time for any other treatment. Socrates suggests that for the sake of the city, no person should be given such leisure to treat an illness, for the function of the human being in this city in speech is to perform his task for the good of the larger community:

[Asclepius] knew that for all men obedient to good laws a certain job has been assigned to each in the city at which he is compelled to work, and no one has the leisure to be sick throughout his life and treat himself. It's laughable that we recognize this for the craftsmen, while for the rich and reputed happy we don't. $(406 c)^{21}$

He then goes on to suggest that not only the ordinary carpenter, but also the guardian or leader who becomes chronically ill, must not be treated if treatment cannot restore him to health. For Socrates, the perpetually ill man would find 'no profit' in going on living (407a).

Socrates' words here seem harshly insensitive to the plight of the ill, not only in overlooking the suffering of illness and fear of death. The good of the individual here seems to exist only insofar as he benefits the community. Through work, a person gains value in the community, but activities outside of these contributions of 'one man, one job' on the Republic's model of justice seem to be of insignificant consideration. Such a view of the city has rightly been questioned and criticized for its lack of care for the human individual. Yet, Socrates' indifference here to the ill stands in sharp contrast to his care and

${ }^{21}$ Bloom's translation of the Republic is used throughout this chapter. See Plato's Republic trans. Allan Bloom, 2nd edn. (New York: Basic Books, 1991). 
continued 'treatment' of persons such as Charmides, Critias, Callicles, or Alcibiades who struggled with health of the soul. Indeed, strong parallels between philosophy and medicine further problematize the Republic's denial of treatment of the ill and whether such a view can legitimately be ascribed to Plato.

Michael Frede, in his book Essays in Ancient Greek Philosophy, argues for the deep interconnections between ancient philosophy and ancient medicine. He notes that the author of the Decorum, a treatise on Hippocratic medicine, thought philosophy should be part of medicine, and medicine a part of philosophy. Such an understanding of the connection between philosophy and medicine ranged far beyond the concern that doctors be aware of ethical issues, or become interested in matters of bioethics as theory. The interconnectedness of the two enterprises rests on their common understanding of the significance of knowledge and its limits. Both were concerned with giving an account of nature, especially its most complex features, as seen in the human body. ${ }^{22}$ Various competing theories of medicine abounded, with those who emphasized the practical value of trial and error, and those who emphasized theory. ${ }^{23}$ However, both philosophy and medicine purported to offer overarching understandings of the 'good life', often each taking up similar problems, but in the light of a different fundamental $\tau$ étos. For example, both physicians and philosophers were concerned with the moderation of the passions, with the health of soul and/or body as a proper balancing of its elements, and finding practices or regimens that might bring the practitioner to a better state. ${ }^{24}$ The physician, as much as the philosopher, might be concerned with the nature of the soul, whose problems could also be addressed by a medicinal regime. It would be a mistake, for example, to suggest that the philosopher tends to the soul, while the doctor to the body, in the Greek mindset more generally. Instead, both medicine and philosophy sought to look to the well-being of the whole of the person, and even to the relationship between body and soul.

\footnotetext{
22 See chapter 12 of Michael Frede, Essays in Ancient Philosophy (Minneapolis: University of Minnesota Press, 1987), 227.

${ }^{23}$ Frede, Essays in Ancient Philosophy, 235-8.

24 See Pierre Pellegrin, 'Ancient Medicine and its Contribution to the Philosophical Tradition', in Mary Louise Gill and Pierre Pellegrin (eds.), A Companion to Ancient Philosophy (Oxford: Blackwell, 2006).
} 
Brill has argued that the medical imagery in the Republic extensively informs the language of its argument. ${ }^{25}$ Medical terms are used to describe epistemological states and ethical and political concerns, especially insofar as medical language is used to distinguish the health of the philosopher from the diseased soul of the tyrant. Even metaphysical passages in the Republic contain medicinal language. For example, the language of the divided line concerning the visible and intelligible realms closely parallels passages in the Hippocratic corpus that note two ways of diagnosing: through the disease being visible to the doctor, or through the doctor's seeking an intelligible cause for what is not directly visible. ${ }^{26}$

Philosophy and medicine are both also concerned with relationships; in the case of medicine, a relationship between doctor and patient that extends far beyond the treatment of a disease to the treatment of the person. Hippocrates' treatises on medicine, while theoretical at moments, are also deeply attentive to the care of the person. Hippocrates offers a philosophical component to medicine. Conversely, philosophy could be understood as a kind of $\theta \epsilon \rho \alpha \pi \epsilon i \alpha$ for the soul. Nussbaum has treated this concept of the philosopher as a kind of caring and compassionate physician in her work The Therapy of Desire. For Nussbaum, the philosopher does not concern himself solely with the intellectual difficulties of his interlocutor, but also with their emotional lives: what they love, fear, and desire. Since beliefs are closely linked to our affective lives, reshaping one's beliefs also reshapes our desires. ${ }^{27}$

While Nussbaum's own emphasis is on later Hellenistic philosophy, Socrates also might be an exemplar of a caregiver for the soul. Indeed, in the Charmides, Socrates even compares himself to a doctor practising Zalmoxian medicine when he offers to treat Charmides' headache. ${ }^{28}$ Not only the contemporary psychologists, but also ancient

25 Sarah Brill, 'Diagnosis and the Divided Line: Pharmacological Concerns in Plato's Republic', Epoché 9 (2) (2005), 297-315.

${ }^{26}$ For the full argument, see Brill, 'Diagnosis and the Divided Line', 302-9.

27 Martha Nussbaum, The Therapy of Desire: Theory and Practice in Hellenistic Ethics (Princeton: Princeton University Press, 1994).

${ }^{28}$ Elsewhere, I argue that the 'incantation' that Socrates provides to Charmides is found in his philosophical questioning of Charmides' beliefs. See Marina McCoy, 'Philosophy, Elenchus, and Charmides's Definitions of Sophrosune', Arethusa 38 (2005), 133-59. An extensive analysis of the links between medicine and philosophy in the Charmides can be found in Francis P. Coolidge, Jr., 'The Relation of Philosophy 
practitioners were aware that in cases of mental disturbance, talk and 'philosophical therapy' of a certain kind might benefit the patient. ${ }^{29}$ Both philosophy and medicine require a certain kind of engagement with the other as vulnerable-whether physically wounded or wounded in soul-as well as acknowledging one's own limits, for example, the doctor's limits as healer. As Brill notes, Hippocratic medicine 'requires both investment and detachment'. ${ }^{30}$ The healer must be invested in the care of his patient, but also detached enough to make a critically informed diagnosis. Socrates, too, possesses such a combination of care and detachment in his attitude toward his interlocutors. Both qualities are needed, insofar as he has limits in his roles as questioner, midwife, and even friend.

We also find physical vulnerability at the heart of many scenes in the Platonic dialogues. Alcibiades will be poisoned. Socrates' body will gradually become numbed as he drinks the hemlock. Theaetetus in that dialogue's prologue is being carried away on a stretcher from injury in the battlefield to Athens so that he may fulfil his wish to die in his home city. Philosophy ignores the body at its peril, just as an understanding of medicine that overlooked questions of meaning would be incomplete. When we hear Socrates in the Republic speak of justice as the harmony of the soul, it is not a far cry from the Hippocratic theory of humours, which stated that health was to be found in the balance of all the interior elements of the human body. In the Timaeus, Critias even describes all soul sickness in terms of bodily imbalance: after describing the nature of some bodily disorders, he moves on to the nature of disorders of the soul:

The disorders of the soul, which depend upon the body, originate as follows. We must acknowledge disease of the mind to be a want of intelligence; and of this there are two kinds; to wit, madness and ignorance. In whatever state a man experiences either of them, that state may be called disease; and excessive pains and pleasures are justly to be regarded as the greatest diseases to which the soul is liable.... He who has the seed about the spinal marrow too plentiful and overflowing, like a tree overladen with fruit, has many throes, and also obtains many pleasures in his desires and their offspring, and

to Sophrosune: Zalmoxian Medicine in Plato's Charmides', Ancient Philosophy 13 (1) (1993), 23-36.

${ }^{29}$ Frede, Essays in Ancient Greek Philosophy, 227.

30 Sarah Brill, 'Medical Moderation in Plato's Symposium', Studies in the History of Ethics, Symposium on Bioethics, accessed online at <http://www.historyofethics.org $>$, 2006. 
is for the most part of his life deranged, because his pleasures and pains are so very great; his soul is rendered foolish and disordered by his body; yet he is regarded not as one diseased, but as one who is voluntarily bad, which is a mistake. (Timaeus $86 \mathrm{~b}-\mathrm{c})^{31}$

In approaching the question of medicine, Hippocrates was well known for searching for causes of disorders as fundamental to the medical practice; he is often remembered for his theoretical bent in medicine. However, as his essay 'On Injuries of the Head' demonstrates, Hippocratic medicine starts with the particular patient. Notwithstanding the ways in which a Hippocratic treatise is a general treatise on rules and even causes that can be applied in order to understand many cases, his first words are about consideration of the particular other before the physician: 'Men's heads are by no means all like to one another, nor are the sutures of the head of all men constructed in the same form.' ${ }^{32}$ A physician cannot look at the wounds of all identically, for not only the wounds themselves, but the underlying state of the physical body that the patient brings along with the wound varies from person to person. Hippocrates says, 'In the first place, one must examine the wounded person (10)', and this principle, that the person is first, and the wound or the condition is later, runs throughout his work. The Hippocratic injunction to 'do no harm' implicitly recognizes the limits of the physician in treating a patient.

Hippocrates also emphasizes that the doctor must recognize his own limits. Hippocrates cautions that many supposed cures for head wounds cause more harm than doing nothing at all. He warns:

In a wound of the head, you must not apply anything liquid, not even wine, but as little as possible, nor a cataplasm, nor conduct the treatment with tents, nor apply a bandage to an ulcer on the head, unless it be situated on the forehead, in the part which is bare of hairs, or about the eyebrow and eye, for wounds occurring there require cataplasms and bandages more than upon any other part of the head. ('Injuries' 13)

Underlying this understanding of non-intervention in certain cases is the belief in the idea that a body is often better situated to restore itself to health than is the doctor. Hippocratic medicine relies upon the idea

\footnotetext{
31 Plato, Timaeus, trans. Benjamin Jowett (Mineola, NY: Dover, n.d.).

32 Hippocrates, 'On Injuries of the Head', trans. Francis Adams, ebooks@Adelaide, $2007<$ http://ebooks.adelaide.edu.au/h/hippocrates/head $>$.
} 
of health as an imbalance that the body seeks to naturally restore when out of balance; at best, a doctor is the facilitator of the process that allows this natural healing to take place. Many of the procedures that Hippocrates outlines in his work are to remove dead skin, scrape at infected bone, or take apart that which would threaten healing, but his work is not to cause the healing itself. Rather, his actions simply leave the room for the body to heal what ails it, through a closing of the wound, and restoration of balance to the humours.

A similar kind of concern for persons in their particularity is present in Socrates' interactions with his interlocutors. For example, Socrates is harsh with Callicles in his arrogance, more playful with his friends in the party-like atmosphere of the Symposium, and someone who 'bites at' Alcibiades like a snake (in Alcibiades' view) in an attempt to awaken him from his political slumber of soul. He does not apply a universal method to all souls at all times; as Gary Scott has recently suggested, $\mu \epsilon^{\prime} \theta 0 \delta o s$ in the dialogues is more likely to mean 'way' or 'path' than a precise method. ${ }^{33}$

Medicine, too, cared for the soul, along with the body. As Bartos has argued, throughout the Hippocratic corpus, the body and soul are treated as part of a single, indissoluble unity, and not as two distinct kinds of substances. Body and soul alike are part of a deeper unity of the human being who is the patient, and so there could be no false separation of treating the person's body but not his soul. Even when we ordinarily talk about our physical experiences of suffering, we speak of ourselves as intimately connected to those experiences. I do not say, if I really hurt, 'My body has this pain,' but rather, 'I am in pain.' On the Hippocratic model, too, the physician, must treat the person, not only his body, as a unified whole, understanding both body and soul to be manifestations of a unity that in a state of health reflects balance and wholeness. Democritus extended this idea of unity of body and soul even further when he argued that it is better to treat the soul, the psyche, than the body: 'It is fitting for people to take account of the soul rather than the body. For perfection of the soul puts right the bad state of the dwelling, but strength of the

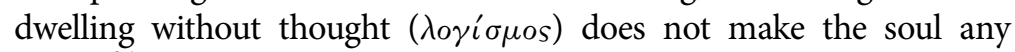
better. ${ }^{34}$ As Bartos explains, since a housekeeper cares for his house

\footnotetext{
${ }^{33}$ See Introduction to Gary Scott (ed.), Philosophy in Dialogue: Plato's Many Devices (Evanston, Ill.: Northwestern University Press, 2007).

34 Hynek Bartos, 'Varieties of the Ancient Greek Body-Soul Distinction', Rhizai 3 (1) (2006), 72.
} 
but not vice versa, care of the soul has positive consequences for the well-being of both body and soul. Democritus saw speech and reasoning as the best way of driving out suffering from a soul, a parallel to the Socratic practice of dialogue as a kind of $\theta \epsilon \rho \alpha \pi \epsilon i \alpha$.

To this extent, medicine is an excellent place where we can look at the intersections of theory and practice, in the context of woundedness. For Socrates, to speak is already a kind of practice, a practice of caring for the soul, and so also for the whole of the human being, body and soul. Because the soul, as the source of the person's choices and actions, is primary, there can be no treatment of certain kinds of wounds or diseases without the patient's cooperation, and so without attending to his soul. Even Gorgias admits this is so, when he argues that he is better suited to persuade a patient to take his medicine or to undergo painful surgery than his brother the doctor, for he can motivate action with persuasive devices in a way that the doctor's technical art cannot. Thus, philosophy as a $\theta \epsilon \rho \alpha \pi \epsilon^{\prime} \alpha$ finds its roots in the earlier practices of the rhetoricians and even sophists, although with a different purpose in mind.

In many dialogues, the Platonic view seems to be sceptical as to

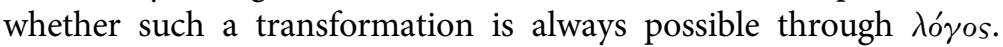
Notably, Socrates is not successful in his changing Charmides, even after he promises to try to heal him, and Charmides agrees. The end of the dialogue features thinly veiled jokes about a 'plot' of force against Socrates, an apparent allusion to Charmides and Critias' participation as especially notorious members of the Thirty Tyrants in the oligarchic revolution and overthrow of Athenian democracy (Charmides $176 \mathrm{c}-\mathrm{d}$ ). Callicles is not converted to the practice of virtue as far as we know, despite Socrates' concerted efforts. Still, we can understand Socrates' philosophy to be a form of $\theta \epsilon \rho \alpha \pi \epsilon i \alpha$, albeit one that is not always successful with its patients, any more than a doctor's treatments can guarantee the health of his. Indeed, Socrates cannot guarantee a successful outcome in his interlocutor. To possess self-knowledge in understanding his limits as healer is part of his art. ${ }^{35}$ Because he recognizes his own limits in affecting his interlocutors, Socrates refuses to be called a teacher.

35 Brill makes the point in relation to medicine that restraint and decision not to treat when a patient cannot be aided are constitutive of the doctor's art in a way that is not true for other $\tau \epsilon^{\prime} \chi v a \iota$ such as carpentry. Brill, 'Medical Moderation', 11. 
Here we might find an avenue for questioning Nussbaum's claim that Plato seeks the perfectionism of the city and of the human person through philosophy. To be sure, Plato suggests that the ordinary ways of the many can be mistaken, especially in their understanding of whether the lives they advocate, for example, of bodily pleasure or political power alone, can really make us happy. The Republic's claim that the chronically ill ought not be treated remains morally problematic. However, this is not to suggest an overarching theory for the perfectibility of human nature. If anything, Plato emphasizes that Socrates is limited, so limited that even at the end of his long and apparently just life, he can still say that his greatest wisdom is that he knows nothing. He is also limited as a practitioner of $\lambda o^{\prime}$ yos, limited in what he can and cannot say to convert others to this life of virtue and a more expansive understanding of human wholeness than that found in the ideas of a Callicles.

Not all wounds are curable. In such a case, the doctor nonetheless has a role in responding to his patient's woundedness. Hippocrates somewhat cryptically remarks, 'When a person has sustained a mortal wound on the head, which cannot be cured, nor his life preserved, you may form an opinion of his approaching dissolution, and foretell what is to happen from the following symptoms which such a person experiences' (emphasis mine, 19). In the myth of judgement at the end of the Gorgias, Socrates seems also to provide such an opinion about Callicles-not even because he is confident that such an opinion will change the outcome, but because he is responsible to state the truth about his patient's condition. Socrates' own $\theta \epsilon \rho \alpha \pi \epsilon i \alpha$ has limits with a soul that is already scarred and that refuses to look at its own state with candour.

In the Theaetetus, Socrates identifies himself as another kind of medical practitioner, this time not the physician of the Charmides, but instead as a midwife. The image of a midwife presents a rather comical picture of a Socrates, who describes himself like a woman who is barren but fruitful in his ability to help others to give birth. He describes himself also as a matchmaker who can bring together the best so that their children might flourish, alluding to his uncanny ability to find the right figure, whether it be Homer, Protagoras, Sappho, or others who provide the 'seed' for his interlocutor to give birth to his own, new idea. The midwife's task is even humbler than that of the physician; while the physician seeks to heal the soul through diagnosis and treatment according to his art, the midwife 
places trust in the human being's own innate generative abilities. The midwife is only there to assist, and to help determine if this is a real birth, or only a false one. ${ }^{36}$

While Socrates is not always a model of gentleness in disposition, we can nonetheless say that his speech at least includes an understanding of the human being as vulnerable, fallible, yet also responsible. One must, of course, acknowledge Socrates' seemingly inhuman episodes of walking in the snow barefoot; being the only one who does not cry at his own death scene; his immovability to Alcibiades; and his annoying, gadfly-like questioning of his fellow citizens and even friends. But perhaps his friends were attracted to him, and could tolerate the more challenging aspects of Socrates' personality because they knew that Socrates knew what the human being was like underneath the clothing of social status, wealth, and crafty speech, and yet, never shirked that nakedness. As one who knew of his own limitedness, he knew how to speak to others in theirs. In this way, Socrates exercised his own form of the political art.

${ }^{36}$ For an excellent account of Socratic midwifery, see Scott Hemmenway, 'Philosophical Apology in the Theaetetus', Interpretation 17 (1990), 323-46. 
This is an open access version of the publication distributed under the terms of the Creative Commons AttributionNonCommercial-NoDerivs licence (http://creativecommons.org/licenses/by-nc-nd/3.0/), which permits non-commercial reproduction and distribution of the work, in any medium, provided the original work is not altered or transformed in any way, and that the work is properly cited. For commercial re-use, please contact academic.permissions@oup.com 


\section{5 \\ Eros, Woundedness, and Creativity in Plato's Symposium}

Plato's Symposium speaks to the vulnerability of eros. Among the topics addressed is that of love's incompleteness and the vulnerability that arises from incompleteness. While Socrates' claim that love is the offspring of Poverty and Means is undisputed, many question whether the incompleteness of eros is overcome, or remains perpetually a lack within us, and whether overcoming such a lack completely would be good on Socrates' view. This question of incompleteness also extends to the question of whether the desire for the universal means also to leave behind the particular. Scholars have been of two minds as to whether the ascent to the good, as described by Diotima, is one that takes up and incorporates the previous objects of love, or leaves them behind in order to focus solely on the good. More precisely, one might ask whether the vulnerability to another person that we experience in falling in love is left behind when we fall in love with, and ascend to, 'the good', or whether the two somehow coalesce. If one loves the good, and is vulnerable to it, is such a person still also vulnerable to other human beings? Or does Plato intend that we achieve contemplation of the good, and so overcome vulnerability?

The well-known ascent passage in Plato's Symposium seems to advocate leaving behind the particulars of this world in order to achieve love of the most 'real' objects of all, namely the forms. The form of beauty is the ultimate $\tau \epsilon$ tos of love, and each previous step described as a means to ascend to this final good. ${ }^{1}$ Diotima suggests

1 As Payne has argued, however, this teleology is not of the sort where an action is performed for the sake of an end, for the lover lower on the ascent has no idea of what awaits at the ascent's end; he is unaware of the nature of Beauty itself, which 
that all the other loves of our lives are ultimately for the sake of that final love, Beauty itself, which is its primary motivating force. However, critics have also seen her presentation of love as being a little too 'other worldly'. If the ladder of love is for the sake of the forms, then it seems that once we reach them, we need neither the ladder nor the many loves that helped us to arrive at the forms. We also then leave behind our vulnerability to other persons. Vlastos famously writes that Plato's understanding of love leaves behind any care for the particularity of the individual person: 'The individual, in the uniqueness and integrity of his or her individuality, will never be the object of our love. ${ }^{2}$ Nietzsche even saw in Plato's metaphysics the root of nihilism: in loving the (for him, invented) forms instead of worldly things, we end up loving nothing at all. ${ }^{3}$

However, I shall argue that Plato does not present us with an impoverished or 'other worldly' understanding of love. Instead, he offers a rich series of accounts that are attentive both to the goods of this world and to the good of the loving soul itself. My argument will have two parts. First, I will argue that for Socrates, eros is always relational. Eros is never only about the lover or the object of love, but always about a lover, a beloved, and the creative acts that result from the encounter between lover and beloved. Such a triadic understanding of love suggests that not only the forms, but also others in the world, are participants in the activity of loving. This triadic notion of eros requires ongoing vulnerability by lovers to others outside of themselves. Diotima's account of love preserves love's complexity in focusing on reproduction as the key to eros. While vulnerability could be understood only as a lack or an impoverishment, Diotima instead presents incompleteness as the very source of human creativity. Indeed, creative love born out of vulnerability transforms the

nonetheless is pulling him along in his unknowing pursuit. See Andrew Payne, 'The Teleology of the Ascent in Plato's Symposium', Apeiron 41 (2008), 123-46.

${ }^{2}$ Gregory Vlastos, 'The Individual as an Object of Love in Plato', in G. Vlastos, Platonic Studies, 2nd edn. (Princeton: Princeton University Press, 1981), 39. Against this view, Nehamas writes, 'The philosophic lover does not reject the beauty of what he leaves behind as he rises toward the Form. Although he discovers beauties that exceed anything he has already seen, the beauty of what he leaves behind does not disappear; only its brilliance diminishes, as the moon's radiance wanes in the light of the sun.' See Alexander Nehamas, " "Only in the contemplation of beauty is human life worth living”, Plato Symposium 211d', European Journal of Philosophy 15 (3) (2007).

${ }^{3}$ E.g. Friedrich Nietzsche, Birth of Tragedy, trans. Walter Kaufman (New York: Vintage, 1967). 
neediness of the lover into a creative force that is outwardly oriented toward the world and others in it, rather than inwardly oriented toward oneself. Paradoxically, lack and longing lead not to narcissism, but rather to a relational and creative orientation to the world.

Second, I examine the scene in the Symposium in which Alcibiades declares himself to be wounded by a 'snakebite' in his time with Socrates. The relationship between Alcibiades and Socrates complicates the picture of eros laid out in Diotima's speech. Alcibiades questions whether Socrates is able to love others in their particularity, and suggests there is a problem with Socrates' universal and even somewhat detached approach to loving others. Further, while Alcibiades is open to eros and even to a sense of his own limit at times, he fails to ascend along the kind of path that Socrates envisions for a lover. Alcibiades admits his vulnerability to the forces of erotic love, shame, and even old age. To this extent, he is more vulnerable than many other characters in the dialogue. However, Alcibiades is unable to transform his vulnerability from awareness into action. Plato's inclusion of this Alcibiades-who possesses some self-knowledge, yet is unable to transform his life accordingly—suggests Plato's sensitivity to the tragic.

Plato's critics have had good reason to worry about the 'other worldly' nature of Platonic love. For example, Diotima's ascent passage does seem to advocate moving from love of particular things to things that are more and more general: a particular boy's body is no longer seen as beautiful when one realizes the beauty of all bodies. Presumably when one cares more for vópoı (laws), political institutions, learning, and so on, the value of these beautiful bodies is lessened even further. The universal seems to be valued at the expense of the concrete and interpersonal. This other worldly sentiment seems to culminate when Diotima finally describes the form of Beauty itself as something apart from the ordinary world. One of the most striking passages in this regard is near the conclusion of Diotima's teaching:

What then do we suppose it would be like, she said, if it were possible for someone to see the Beautiful itself, pure, unalloyed, unmixed, not full of human flesh and colors, and the many other kinds of nonsense that attach to mortality, but if he could behold the divine Beauty itself, single in nature? 
Do you think it a worthless life, she said, for a man to look there and contemplate that with that by which one must contemplate it, and to be with it? $(211 \mathrm{e}-212 \mathrm{a})^{4}$

While the ordinary world might be the needful route to the forms, once the forms have been accessed, then the world of the ordinary seems not just inadequate, but a mere imitation, pale, in contrast to the vivid reality of the form which is most worthy of love.

However, Diotima's ideas here must be contextualized in the whole of her speech and the series of other speeches in the Symposium. In recent years in Platonic scholarship, much has been made about the importance of distinguishing Socrates' words in the dialogue from Plato's own meaning as author. ${ }^{5}$ Diotima is a single voice, one of the most persuasive voices in the dialogue, but her voice is mediated not only through Socrates, but also through the storytelling that frames the dialogue, as Apollodorus narrates the discussion to an unnamed friend. ${ }^{6}$ We are not even certain that the story is entirely faithful to the reality, as Apollodorus admits that he has forgotten some parts. ${ }^{7}$ But the presence of the framing device highlights that each account of love takes place in a larger context of interchange between different people with different understandings. Later speakers at the symposium explicitly address the ideas of earlier ones, sometimes rejecting them and sometimes reincorporating them at a newer and more complex level. Plato's presentation of love is found in the whole of the Symposium and not in the ascent passage alone.

Two elements within the ascent speech suggest a more nuanced approach to the interrelation of love of others and love of Beauty itself. First, Diotima's speech uses the language of fertility and reproduction to discuss human love, precisely at the point at which the person on the ascent begins to approach the form of Beauty, but has not yet attained

4 Translations are from Plato, Symposium, trans. R. E. Allen (New Haven: Yale University Press, 1991), with permission.

5 Charles Griswold, 'Irony in the Platonic Dialogues', Philosophy and Literature 26 (1) (April 2002), 84-106.

${ }^{6}$ For a thorough account of the philosophical importance of narration in the dialogues, see Ann-Marie Bowery, 'Know Thyself: Socrates as Storyteller', in Gary Scott (ed.), Philosophy in Dialogue Form: Plato's Many Devices (Evanston, Ill.: Northwestern University Press, 2007), 82-109.

7 Kevin Corrigan and Elena Glasov-Corrigan, Plato's Dialectic at Play: Argument, Structure, and Myth in the Symposium (University Park, Pa.: Pennsylvania State University Press, 2004). 
the final goal. Diotima herself does not reject love of particulars in favour of contemplation, because it is precisely in the encounter of human lover and beloved that creative acts take place. Second, if we compare her account to earlier accounts of love of the particular and its role in reproduction, Diotima most of all emphasizes the creativity inherent in love, a creativity that is fruitful for the human world, and not the world of the forms. The speeches that precede Socrates' speech are deficient for their inattention to the creative and fruitful tension inherent in love. Socrates' speech alone preserves the importance of not only lover and beloved, but also 'reproduction' in loving.

In determining whether love of the forms is other worldly, it is necessary to understand the relation between loving the forms and loving individuals. If, for example, individuals are loved only as reflections of the forms, then it would seem that love of the forms is by its nature an abandonment of love of individuals as individuals. In such a case, the lover does not love his beloved's beauty, but only a reflection of Beauty itself in the beloved. However, articulating how one loves an individual beloved even in 'ordinary' accounts of eros, excluding the forms, proves to be philosophically difficult.

One way to understand erotic love for an individual is as love of his or her qualities. On this account, one loves another because of her compassion, or wry sense of humour, or because she enjoys the same sports. This seems true even in cases of non-erotic love. Even if one loves one's child apart from his particular qualities (e.g. a mother might love a literary child just as much if he had been an athletically driven competitor), one might still argue that this love is driven by the child's specific qualities, albeit at a different level. She loves him because he is her child. Still, love of a person for his qualities can seem trivial when one contemplates the temporary nature of many personal traits. As Stern-Gillett notes, Pascal pointed out the difficulty at hand in his Pensées:

What is the self? A man goes to the window to see the people passing by; if I pass by, can I say he went there to see me? No, for he is not thinking of me in particular. But what about a person who loves someone for the sake of her beauty; does he love her? No, for smallpox, which will destroy her beauty without destroying the person, will put an end to his love for her. ${ }^{8}$

${ }^{8}$ Pascal, Pensees, trans. A. J. Krailsheimer (London: Penguin, 1995), 688. I am indebted to Stern-Gillett's book Aristotle's Philosophy of Friendship for drawing 
Pascal goes on to point out that even if we were to say that we love a multiplicity of qualities in another, we still love only qualities and not some 'essential' person. After all, what else is the self other than body and soul, each of which has qualities?

However, to love someone only as a means for seeing the forms would seem to have a parallel problem: if one loves the beauty of the beloved's body because it is reminiscent of the forms, he is apparently loved only as an instantiation of the Form of Beauty, and not in his particularity. The lover does not love his beauty, but rather how his beauty reflects real Beauty. Put together this idea with Diotima's claim that the forms are unpolluted, unmixed, and pure, and one might even conclude that Plato finds the love of a particular body to be somewhat tainted.

An alternative picture might say that to love an individual is to love him for 'himself', with the claim that the self is a being that is impossible to describe adequately. On this model, one loves not simply the beloved's qualities, good and bad, but 'something essential' and indescribable about him that makes him unique. This position has at least two difficulties: first, this way of thinking seems mysterious and incap-

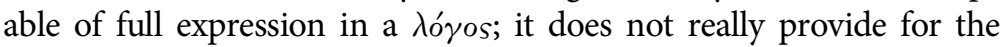
possibility of a philosophical account of love at all. Second, the description seems counterfactual, insofar as at least some of the time, love of another is expressed by extolling his or her good qualities, and even how those qualities are related to one's own needs or desires.

Perhaps what is being said when one claims that we do not merely love someone else for their qualities, is that we do not love them only for their good qualities. That is, in the most profound experiences of love, one loves the whole person, including his or her flaws; that is, the person's vulnerabilities and even errors become the objects of our love. At times these imperfections are related to other goods. For example, we might see how these flaws are linked to other aspects of the person that we consider to be good: she is neurotically picky about a neat house, but also excellent at getting the details right in her projects at work. Or, one loves a certain quirk (for example, unusually shaped ears) because it reminds the lover of the beloved as a whole and what is beautiful. In this case, one loves a human being still for his

attention to this passage in the context of the discussion of love in ancient thought. See Suzanne Stern-Gillett, Aristotle's Philosophy of Friendship (New York: SUNY Press, 1995), 60-1. 
or her qualities, but is simply more generous in how we understand how particular qualities fit together into a coherent and lovable whole.

In the above analysis, the description of love focuses on the nature of the beloved: the qualities or characteristics that he or she possesses such that he or she becomes 'worthy' of love. However, Diotima's speech focuses on how creativity overcomes the mutual incompleteness of both a lover and a beloved. Diotima does not view eros as being about the qualities of a beloved alone, or of a lover alone, or even simply the relationship between lover and beloved. Rather, central to a love relationship is the lover, the beloved, their relationship, and the creative activity that stems from their eros for one another. After all, Diotima's speech is not primarily an account of Beauty, but rather an account of eros. Her speech is not a metaphysical description of the nature of the forms. Rather, the focus of her speech is to convey what it means to love. Eros, for Diotima, is about a well-spring of creativity and reproduction that allows the lovers to go beyond their own and their beloved's personal need.

Diotima's speech begins with a mythical description of the genesis of the god Eros from Poros and Penia. Eros is born of both want and plenty; therefore, Eros cannot be understood as either fullness or complete lack. Eros is always in between the complete and the incomplete; he is therefore neither god nor mortal, but in between mortal and immortal (203e). Diotima even describes Eros as always coming to be and dying away: at night, Eros withers away, but by day is regenerated again (203e). Eros is always vulnerable to loss. However, along with diminishment, Diotima emphasizes the re-genesis of love. We should not regard Diotima's speech with attention exclusively to its ultimate $\tau \epsilon^{\prime} \lambda$ os in the form of Beauty, but rather with attention to the movement of love and love's activities throughout the entire speech. Diotima's speech is not primarily an account of Being, or even of particular beings, but instead about becoming, the becoming of love and love's creative activities.

Diotima's focus upon the genesis and reproduction that occur through love is clear from her choice of words. Diotima's language is positively fecund: her speech is filled with the use of terms such as

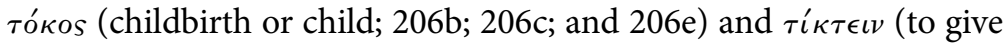
birth; twice at 206c; 206d; and 208e; 209a; 209c; 210b; 210c; twice at 212a), while the more abstract and less metaphorically vivid term $\gamma \epsilon \nu \epsilon \sigma \theta a \iota$ occurs only once in her speeches (204d). In addition, the 
term $\ddot{\epsilon}^{\prime} \kappa \gamma o v o s$, child or offspring, occurs twice (at 190a and 209c). Diotima relies heavily upon the language of childbirth to describe eros. Childbirth is the ultimate image for becoming, since it refers to the creation of a new being, rather than a mere change in the state of already existent beings. The vast majority of Diotima's speech discusses eros and its role in creation, making ( $\left.\pi \circ i_{\eta} \eta \iota s\right)$, birth, death, and immortality (205a-210e). In contrast to her discussion of reproduction, Diotima's discussion of Beauty itself is relatively short, running just a little under one and a half Stephanos pages (210e-212a).

Diotima's speech refers to six kinds of erotic reproduction in the following order: (1) the begetting of Eros himself by Poros and Penia (203a-e); (2) the way in which any genesis in the arts is a kind of $\pi o^{\prime} \eta \sigma \iota s$ in the arts (205b-e); (3) giving birth to physical children for the sake of immortality (207b-208b); (4) giving birth to noble acts, even to the point of death, for the sake of glory, as in Achilles' sacrifice (208c-208e); (5) giving birth to practical wisdom and excellence, particularly in the right ordering of cities and households (208e-209a); and (6) giving birth to discourses ( $\lambda$ ó $_{\circ} \iota$ ) (210d). A remarkable feature of Diotima's speech is the variety and multiplicity of sorts of things that are produced through eros in her view: not only physical children, but also poems, inventions, noble deaths, glorious acts, and philosophical speeches are all different ways in which eros manifests itself. Reproduction includes, but is in no way limited to, physical reproduction. Eros is presented as enormously fruitful and multiple in the sorts of fruits it bears. All six of these sorts of genesis or giving birth require others: we need another person with whom to bear physical children, but also need to love those in our city in order to give them good laws, or to die nobly for them; philosophical discourse requires someone with whom to talk, as we see in the conversation at hand in the Symposium.

The description of the end of the ascent, however, brings to a close Diotima's description of the 'becoming' of the erotic person: once a person has reached knowledge of Beauty itself, his desires are suddenly markedly different from what they were prior to the end of the ascent. While the description of Beauty itself is presented in an overwhelmingly positive light, Diotima also emphasizes the enormous gap between a life that is lived pursuing the creation of beauty and striving for immortality, and a life that is spent gazing at the forms: 
If ever you see it [Beauty], it will not seem to you as gold or raiment or beautiful boys and youths, which you now look upon as dumbstruck; you and many another are ready to gaze on those you love and dwell with them forever, if somehow it were possible, not to eat or drink but only to watch and be with them. (211d-e)

One who has seen Beauty itself will lack interest in the ordinary things of this world, just as those in love with boys lack an interest in plain food and drink. Diotima suggests that one who beholds Beauty itself will want to do nothing but watch and be with the forms: eternal contemplation of Beauty is all that a lover who has discovered the forms will want. There is no going back to an old life once the contemplation of true Beauty takes place. 'Human flesh and colors', and the 'nonsense' of human mortal life, now are irrelevant to the former lover of these things. According to Diotima, all else that came before the end of the ascent seems not to matter to the person who has reached the final goal. One might venture to say that such a person loves only the perfect and invulnerable.

However, if eros is intermediate between wisdom and ignorance, as Diotima emphasizes at 202a, then by definition the one who has become wholly wise is no longer erotic. He has instead reached a final happiness that needs no further explanation for its pursuit (205a). He who contemplates Beauty lacks eros, being already satisfied with complete Beauty-or is only erotic insofar as she wishes to continue having what she already possesses. Either way, the person has reached the end of the ascent: he has nowhere further to go, and lacks the restlessness endemic to those who are still becoming in eros. Eros has not just changed one object for another, but has itself been transformed by this encounter with Beauty. Diotima's speech therefore seems to contain two different accounts of love in tension with one another: an account of love that emphasizes its genesis, movement, and its generative effects in a changing world, and a second account in which love finds completeness and satisfaction.

Ionescu has argued that in Diotima's account of procreation there are two different sorts of immortality: at the lower levels of the ladder, the immortality comes through substitution, in which though the lover dies, something else, a child, an idea, a law, exists after the death. At the higher levels, however, the idea of a substitutional immortality is replaced by an eternity of the 'always', that is, by the idea that Beauty itself is unending and eternal, due to the perfection of the object itself. In these later stages the object's eternal nature is what 
offers solace to the limited, mortal human being, rather than the prospect of some further mortal reproduction that grants a sense of longevity after death. In addition, at the lower levels, human knowledge is understood to be imperfect and temporary, while in later stages it is possible to speak of knowledge that is 'permanent and stable'. ${ }^{9}$ It would seem that the later stages call for a human being to be outwardly focused, less on himself and upon his own immortality than upon the object of his love.

While at a lower level the person who procreates in order to gain a sense of personal immortality 'loves' the other, such a love retains a moment of selfishness. Although the child, physical or spiritual, may be genuinely an object of care (not cared for solely as a means to immortality), still, the presence of the other on Diotima's account is at least in part to fulfil a sense of the desire to be immortal, in the absence of the possibility of temporal immortality. At least to some small extent, the other exists in part for the sake of one's personal fulfilment. However, the human being who progresses along the ascent undergoes a transformation of self and the very nature of his desires. The lover at the highest level of the ascent, who loves Beauty itself for its immortality, and not his own, has undergone a fundamental reshaping of his own values. He now loves the Other (Beauty itself) for its own sake, on account of its own qualities; one might say that the very existence of this other good in its perfection makes the loss of the mortal self somehow more bearable. Eros at its final stage is more fully ecstatic. ${ }^{10}$

At the same time, the life of philosophy takes place not only at the final level of contemplation. Philosophy, as we see it practised by Socrates, takes place at the intermediate levels in which all forms of spiritual procreation take place, for this is where conversation takes place. Those at the highest level of the ascent no longer procreate, but

9 Cristina Ionescu, 'The Transition from the Lower to the Higher Mysteries of Love in Plato's Symposium', Dialogue 46 (1) (2007), 29. Ionescu argues that the theory of recollection is present here as the link between the two levels.

${ }^{10}$ D. C. Schindler, 'Plato on the Problem of Love: On the Nature of Eros in the Symposium', Apeiron 40 (3) (2007), 199-220, persuasively argues that in the final stages of eros, desire is 'naturally ecstatic', not selfish. Against this reading, Kosman argues for a view of Platonic love that is essentially a form of self-love. See L. A. Kosman, 'Platonic Love', in W. H. Werkmeister (ed.), Facets of Plato's Philosophy (Assen: Van Gorcum, 1976), 53-69; Anders Nygren, Agape and Eros, trans. Philip S. Watson (Philadelphia: Westminster Press, 1953); and Gerasimos Santas, 'Plato's Theory of Eros in the Symposium', Nous 13 (1979), 67-75. 
instead contemplate. But Socrates likes to talk. In conversation, one gives birth to some sort of wisdom-or more often, what Socrates in the Theaetetus says turns out to be a 'phantom' (Theaetetus 150c). But philosophy is only philosophy instead of wisdom so long as it is incomplete, and still en route to its final goal. Conversation can only take place when one is open to the other, and becomes aware of one's own lack and need for the other to inform and even transform one's self. Conversation that is open to transformation requires a kind of vulnerable openness that risks the self. Socrates the philosopher is a lover, not a wise man, as evidenced by the fact that he has not reached the end of his ascent, but only heard of it from a mysterious, feminine figure, a kind of philosophical prophetess.

Socrates' description of himself as a midwife in the Theaetetus picks up on the language of procreation. Midwifery seemingly unifies Socrates' love of the good and love of another person, insofar as Socrates' attending each person's birth of ideas is both a care for the integrity of the good (and casting out false goods) and the good of the person who 'gives birth'. Indeed, midwifery is a kind of selfless and generous love, since Socrates' aim is not to give birth to his own ideas, nor to attend to his own needs. Rather, his focus is on the other with whom he speaks, and his relation to the good. While, strictly speaking, a triadic relationship exists between the interlocutor, the good, and Socrates, his aim is to cultivate the other person's relationship to the good. If Socrates also grows in love and understanding of the good in his role as midwife, so much the better, but his fundamental locus of concern is for the other.

Human eros, then, for Socrates, is never about only one person who loves; it is nearly always about a lover and a beloved and the ways in which their love affects the larger world in which they live. Eros gives birth in beauty to beautiful things, but these beautiful things only come into being when there is another present with whom to beget beautiful discourses, art, laws, or children. To those who say that eros is 'really' about certain qualities in the beloved, Socrates might object that trying to understand such love in terms of its object alone is too constricted a view of eros in the first place. Eros is always about a tension and a relation, between lover and beloved, and also between those lovers and what they create as a result of their love: it is a triadic relation between lover, beloved, and the resulting creativity of the pair. Vulnerability and creativity are intertwined, for the creativity arises from lack and from opening one's self and one's need to another. 
Artificially separating out the beloved object's qualities from this greater set of relationships is also a distortion of the lover's selfunderstanding, if he sees his own eros as entirely about the beloved and his qualities. For Socrates presents the lover's eros as being the result also of the incompleteness of the self, its longing, and the effect of that longing in desiring the beloved. In Socrates' account, a selfaware lover sees in his beloved more than a set of qualities if he understands his own eros properly. He sees in his beloved the beloved's qualities, but also something about himself, and something about what the lover and beloved might make or do together. To the extent that such vulnerability gives rise to creativity, the love also brings the individual out of himself and more focused on what is outside of himself. Diotima's account of eros is generously and even lavishly productive and re-productive; these relations between lover and beloved, the things created in love and the longing for more creation to find one's immortality, are more fundamental to the nature of love than static qualities in the object of the beloved. The creative nature of eros, in these penultimate stages on the ladder of love, begins with individual lack and need, but results in the lover's reorientation of his energy and focus on the beloved, outside of himself. Eros that begins with lack, then, does not end in a lover's simple desire to fill his lack. Rather, the lover who is willing to be vulnerable to the beloved is transformed from being simply a needy being, to a being whose creative energies are an outpouring of the self to the beloved and the larger world. To this extent, the fecundity of love at this stage is also ecstatic, in the sense of bringing oneself out of oneself, although focused on the 'ordinary' world and not the world of the forms.

Let us turn to a few brief comparisons of Diotima's speech to earlier speeches in the dialogue in praise of love, for the speeches build on one another, sometimes rejecting and sometimes taking up and elaborating on the ideas of previous speakers. ${ }^{11}$ Phaedrus emphasizes

${ }^{11}$ Rangos characterizes the speeches as akin to a series of stepping stones. Spyridon Rangos, 'On Diotima's Allusions to Earlier Speakers in Plato's Symposium', Skepsis 16 (1) (2005), 168. 
the lover above all else. Although Phaedrus' speech is a speech in praise of Eros the god, his illustrations and examples are all about particular couples; very little is said about the god himself. Phaedrus emphasizes the lover who is willing to die for his beloved. As Diotima will also do later, Phaedrus attributes the valorous actions of warriors to their eros for their beloveds. However, in doing so he claims that the lover is more divine than the beloved (180d). Phaedrus emphasizes the virtue of the lover such that the beloved receives almost no mention in his speech except as a means to the lover's achievements. While it might seem that the beloved is loved in all his particularity, since the lover is willing to sacrifice so much for him, in fact, Phaedrus' speech is an encomium to the lover alone. Eros is good for the lover, and the qualities of the beloved are not that important so long as the lover acts virtuously.

Pausanius' account of eros divides it into two kinds of love, the heavenly and the vulgar. It corrects Phaedrus' overemphasis on the lover by looking at love's different objects. Pausanius claims that heavenly love has a better object than vulgar eros, namely, the best love is of boys who show themselves to have worthy characters. Love of body is inferior to the love of the right kind of soul. Pausanius tries to differentiate between what sorts of actions are good and appropriate in love and what form of gratification is base, but in the end he concludes it is not the type of action performed per se, but rather the beloved's understanding of his lover's character that matters. Even if the beloved makes a mistake, and thinks that his lover is good when he is really bad, this is acceptable. For what matters is that the beloved attempts to act for the sake of his own virtue and self-improvement. While Pausanius reintroduces the importance of the beloved in this speech, his view of eros is no less narcissistic than that of Phaedrus; only this time, the beloved is the centre of erotic desire, and not the lover or his intentions. Again, the relational aspect of the loverbeloved relationship is overlooked in this dyadic (not triadic) account of eros.

One would expect that if any of the speakers present were to discuss the role of reproduction and birth in love, it would be Eryximachus, the physician. Strikingly, his account of love contains almost no reference to the reproductive powers of love, even as it emphasizes $\phi \dot{v} \sigma \iota s$ (nature) throughout. Eros, for Eryximachus, is about the concord and attunement of different elements, as in the case of different elements in the body in the case of health, or 
the attunement and right rhythm of beautiful music. Eryximachus expands upon the previous notions of eros by making them relational; eros is never about only a lover, or a beloved, or even virtue, but is always about the bond and harmony between at least two things. However, in emphasizing the ways in which parts fit together into coherent wholes in nature, Eryximachus says nothing about death, birth, or the generative power of love to overcome human limitations. He ignores what Phaedrus and Pausanius say about the valorous results of love altogether. Neither does he suggest that love plays a role in biological generation, or the regeneration of living things through the art of medicine. Thus, while relational, Eryximachus' account of eros lacks attention to vulnerability or need.

In contrast, Aristophanes presents a relational understanding of eros that does take account of the vulnerability of persons who love. Eros, for him, is a matter of finding one's other half and being reunited to a more primary and primal whole. Since human beings are literally only half of our original selves, we are by our very nature erotic, driven to find the rest of ourselves in the other. Aristophanes makes both halves of this loving relation important; each half is a lover, but each half is a beloved, too. Eros involves lack and neediness, even woundedness, and to understand ourselves we have to also understand what we lack. In this way, Aristophanes' view of eros is more complex and nuanced than in the previous speeches: eros is best understood by looking at both the beloved and the lover's experience of longing. However, Aristophanes also suggests that this erotic drive can never be wholly satisfied, as the lovers never do permanently become one again (although this is their wish). Neither does the human being ever fully understand his own motivations in loving. When the two halves finally meet one another:

they are then marvelously struck by friendship and kinship and Eros, and scarcely willing to be separated from one another for even a little time. These are the people who pass their whole lives with each other, but who can't even say what they wish for themselves by being with each other. No one can think that it is for the sake of sexual intercourse that the one so eagerly delights in being with the other. Instead the soul of each clearly wishes for something else it can't put into words; it divines what it wishes, and obscurely hints at it. $(192 \mathrm{c}-\mathrm{d})$

In other words, eros never fully satisfies. For Aristophanes, the incompleteness of eros is fundamental, and his descriptions of the 
experience of eros' incompleteness seem right: we do not want our beloved merely to talk, to make love, or even to spend a life together, though we might want each of these activities. There is something deeper, a nameless 'more' that speaks to the incomplete and restless nature of ourselves as human beings, and that leads each lover and beloved to seek and to find not an end to restlessness, but a kind of dialectical movement between more or less incompleteness, and more or less fulfilment, through the intimacy with another.

The lovers are literally cut in two, wounded, torn in their individual existences. These lovers experience the world as fundamentally ruptured and each senses that the rupture is within himself. Indeed, Aristophanes even describes individuals as not wholes, but 'slices' of wholes (191e). The navel comes to signify this primal wound, an outward sign of the inner sense that each lover feels of his own incompleteness. Zeus says that the wound remains, while others are healed, in order that 'man would be more orderly by contemplating his own division' (190e). Just as Socrates will later point to the need to acknowledge limit, Aristophanes here points to woundedness as a divine corrective against hubris. The navel, while healed over, always leaves its trace as a reminder of one's own limit. In the mythic account, the navel signifies the wound suffered as a result of hubris, but of course in ordinary human life, it signifies each human being's prior dependence on his or her own mother. ${ }^{12}$ No one enters the world except by being part of a prior whole, from which they later become separated. Thus, the myth reflects a kind of genuine truth about one's own natality as rooted in dependence, a dependence that suffers a rupture that leaves behind a reminder of the prior dependence.

Surprisingly, Aristophanes says little about erotic love and its relation to birth. Aristophanes' lovers reproduce, but Aristophanes only briefly mentions reproduction as a consequence of eros (1911c). Most couples are only interested in the other partner as a means to self-completion, but Aristophanes makes no mention of children or any other sort of creative endeavour as part of the lovers' happiness. Aristophanes' lovers are passionate, but still mostly self-interested as a couple, or interested in their beloved alone, but only themselves and their beloved, as if they were a small cosmos unto themselves. Their love remains an unsatisfying, if compelling, seeking of reunion.

12 Thanks to Jill Gordon for pointing out this connection between the navel and dependence on the mother as implicit in the myth. 
In contrast, Diotima's account of love significantly widens the creative aspect of love, both in the seeking and in the satisfaction a lover has in being a creative, generative being. ${ }^{13}$ The world of the lover expands on Diotima's view beyond the longings of one person for another to complete him.

Agathon's account praises love more than lovers or beloveds. In this way, his description of Eros the god is not unlike Diotima's description of Beauty. Eros is simply perfect: young, wise, just, beautiful, and best in every way. Agathon even mentions the reproductive nature of love explicitly in a multiplicity of ways: eros makes animals have children, makes us poets, makes us craftsmen, and in short, is responsible for a wide variety of beautiful and good human activities. Agathon, like Diotima, connects the creative activities of human beings to love, and makes the relation of Eros (understood as a god) more important than beloved or lover alone. But the deficiency that Socrates sees in Agathon's view of eros is that it overlooks its 'in between' nature, i.e. the lack, the desire, and what is not had, in favour of what is achieved, satisfied, and possessed. Socrates reminds Agathon that this, too, is a crucial part of eros. Eros is not eros without poverty and incompleteness.

But if Socrates is right, then the account of the final contemplation of Beauty itself cannot be read in isolation from the rest of Diotima's speeches about eros's movement. Eros, for Diotima, is about the experience of moving towards an object that can satisfy our desire and not leave us empty handed (in contrast to Aristophanes' lovers). However, at the same time, eros is in that movement and in that relation of self to other, of lover to beloved, and beloved to lover, and also in the relation of each of these to what is created in the encounter with eros. Eros, for Diotima, is about a state of becoming, not only the becoming of the lover and beloved, but also the becoming of the world as the lovers fruitfully contribute to it with their philosophical discussion, their poetry, their children, laws, and other creative acts. The beloved is always incomplete, and imperfect in his qualities, as much as the lover is; however, the creative acts of eros help us to

\footnotetext{
${ }^{13}$ Fussi shows the sense in which Diotima's speech is a response to Aristophanes' speech, not refutative in nature, but rather a more complex development of how love is a response to incompleteness and mortality. See Alessandra Fussi, 'Love of the Good, Love of the Whole: Diotima's Response to Aristophanes in Plato's Symposium', Epoche 13 (2) (2009), 267-90.
} 
overcome our incompleteness and our mortality. In fact, it is because we are incomplete that eros is so productive. Ascent to the forms is a genuine good, but certain kinds of goods (such as philosophy) only come about because we have not yet reached our destination.

\section{III}

If there is any critique of Socrates' and Diotima's views in the dialogue, it is found in Alcibiades' speech. For it seems that as much as Socrates loves the forms, he cannot bring himself to love the particularities of Alcibiades: he seems unmoved by Alcibiades' beauty, unaffected and even dispassionate. And yet, as Nussbaum emphasizes, throughout the Symposium we find allusions to Alcibiades, the passionate lover, who both understood something about eros and yet, needs his eros to be purified. Alcibiades has many identities, writes Nussbaum:

A man who died shot by an arrow will speak of the words of love as arrows, or bolts, wounding the soul (219b). A man who influentially denounced the flute as an instrument unworthy of a free man's dignity will describe himself as a slave to the enchanting flute-playing of a certain satyr (215b-d, 216c, 219c). A man who will deface holy statues compares the soul of Socrates to a set of god-statues, and speaks of the injustice of rubbing out, or defacing, Socratic virtues (213e, 215b, 216d, 217e, 222a). ${ }^{14}$

With Alcibiades' arrival, what was seemingly a private dialogue, a matter of entertainment among a small group of friends who enjoyed discussing and debating eros, suddenly takes on enormous political significance. For Alcibiades' discussion of eros here is reminiscent of his other famous association with eros, namely, the accusation that he defamed the hermai. Such defamation was a political act, an iconic representation of Alcibiades' apparent disdain for the city and its religious and political institutions, as a result of his own corrupting political ambition. While Socrates may have cared for and sought to teach Alcibiades, Plato's dialogue was composed long after his death, and after the dire consequences of his betrayal of Athens and the

\footnotetext{
14 Martha Nussbaum, 'The Speech of Alcibiades: A Reading of Plato's Symposium', Philosophy and Literature 3 (2) (1979), 133.
} 
results for Athens's decline in regional power had become clear. For Plato's audience, to understand Alcibiades' speech on love here cannot have the apolitical associations that it seems to have had for the characters internal to the dialogue; his claim that he was never able to resolve his unhappiness with himself and his ambitions takes on an especial poignancy closely linked to the poignancy of Athens's larger political losses.

Alcibiades, however, understands his account of love to be acutely personal. Alcibiades describes himself as not only vulnerable to love, but already wounded. He says of himself:

I'm almost like a man who's been bitten by a snake. They say that anyone who's suffered it is unwilling to tell what it was like except to those who have been bitten, because they alone will sympathize and understand if one was driven to do and say everything in his pain. Well, I'd been bitten by something more painful, and in the most painful place one can be bittenin the heart or soul or whatever one should name it, struck and bitten by arguments in philosophy that hold more fiercely than a serpent, when they take hold of a young and not ill-endowed soul and make him do and say anything whatever. (217e-218a)

While Alcibiades had thought he 'had loosed his arrows and wounded him [Socrates]' (219b), Socrates turns out to be invulnerable not only to Alcibiades' seductive words, but also to the inebriating effect of wine (220a), to money (219e), and even snow on bare feet (220b). ${ }^{15}$

Alcibiades wants from Socrates the passion of a lover, but instead receives the affection of a father figure. When Alcibiades speaks of his uneventful night under the covers with Socrates, one senses not so much sexual frustration, as a desire to be special to Socrates, to be something more than a person whom Socrates wishes to bring to the 'good'. Insofar as Alcibiades feels treated by Socrates as simply 'one who ought to ascend to Beauty', as a potential philosopher, he feels Socrates has not loved him as himself, his particular, quirky, passionate, flawed, ambitious, handsome, confused, particular self. Howland notes the similarity between Alcibiades' understanding of Socrates as satyr-like, and the satyr in Euripides' Cyclops, who delights in mocking others just after he has succeeded in getting them to be their most exposed and vulnerable. Alcibiades' comparison of Socrates to a satyr

15 Jacob Howland, 'Plato's Dionysian Music: A Reading of the Symposium', Epoche 12 (1) (2007), 31. 
indicates his sense of Socrates' strangeness and seeming removal from the ordinary passions of other human beings. ${ }^{16}$

Alcibiades even implies that if only Socrates would love him in the way that he wants to be loved, he might be inspired to live a better life. Socrates seems only to care about loving knowledge and seeking the truth through conversation; the speech of Alcibiades calls into question whether this is really enough. Alcibiades is drunk, and his speech is about the drunken, manic, possessed aspects of love entirely overlooked by other characters so far. For Alcibiades, eros is painful, crazed, as much about Bacchic possession as about valorous action. Alcibiades says that part of why he loves Socrates is that Socrates is full of beautiful tó yo that contain images of virtue (222a), but loving a virtuous beloved turns out to be insufficient to make Alcibiades virtuous. For him, eros is not only a source of beauty and creation, but also-if frustrated-a source of suffering and destruction. ${ }^{17}$

While Socrates emphasizes the importance of care for the soul through the pursuit of the philosophical life, Alcibiades raises the question of the sufficiency of this view. He asks, Socrates may love the others as partners in conversation, but can he say of anyone (as Alcibiades says of him) that there is absolutely no one who has affected him in this way, that there is another of whom he can say, 'I will never find another one just like him'? Is Socrates open to an eros that can weaken and transform him as a 'whole' human being, and not only as a seeker of Beauty itself?

Here Alcibiades displays his vulnerability, not only admitting to his desire for Socrates (contrary to the Greek expectation that the beloved ought to resist his lover while the lover pursues with open desire). $\mathrm{He}$ knows of his shortcomings and of his need to transform his life from an ambitious political life to a virtuous, philosophically informed care for his soul:

For he compels me to agree that though I am much myself in need $(\dot{\epsilon} v \delta \epsilon \dot{\eta} s)$, I neglect myself and attend to the affairs of Athens. So I stop my ears by force as if against the Sirens and run away $(\phi \epsilon \dot{\gamma} \gamma \omega \nu)$ in order that I may not grow old sitting here beside him. Before him alone among men I suffer what one might not have supposed is in me-shame before anyone. Before him alone

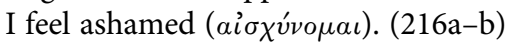

${ }^{16}$ Howland, 'Plato's Dionysian Music', 32.

17 Jill Gordon brings out the tragic element of Alcibiades in the Symposium in her book Plato's Erotic World (Cambridge: Cambridge University Press, 2012), p. 180-3. 
Alcibiades is unrestrained in his ambition and concern for the praise of the multitude, except around Socrates. Socrates' presence to him as a lover makes him, the beloved, aware of a latent sense of shame. That shame arises from a desire to look good in the eyes of Socrates, but also explains his awareness of his own need. His use of the verb '́ $\nu \delta \epsilon^{\prime} \omega$, translated here as 'need', indicates a lack or falling short, of which Alcibiades is self-aware. Unlike the Aristophanic lovers, who know only that they lack 'something' and so seek a lover without full selfawareness, Alcibiades even knows that the solution is to care for his soul and to stop attending to the attention of the multitude.

Alcibiades here reveals his great desire not to be vulnerable in three key ways in which he might show weakness: personal need; old age; and shame. These three forms of vulnerability that Alcibiades wishes to avoid are interrelated. Alcibiades must 'stop up his ears' (literally close himself off to prevent Socrates' words from entering into his inner being) because if he were truly honest with his neglect of his own soul even when apart from Socrates, shame would be a natural result. ${ }^{18}$ Even his admitted fear of growing old, being a philosopher like Socrates instead of an active man of the city, reflects the idea behind Diotima's claim that we seek immortality in accomplishment, knowing that life comes to an end. Alcibiades hints that his lack of shame and lack of care for his own soul comes from a fear of old age and even death, which leads him to ignore these difficult, but important, truths about human existence, in favour of an active political life and Dionysian approach to eros. His entrance into the symposium, drunk, crowned with ivy and violets, is suggestive of this Dionysian element in Alcibiades. ${ }^{19}$

Other ancient authors also describe Alcibiades as possessing an overinflated sense of pride. Thucydides, for example, writes that Alcibiades defended his expenditures at the Olympics by saying that

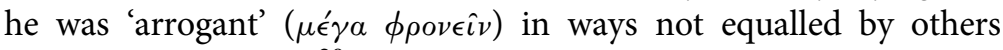
(Thucydides 6. 16. 2). ${ }^{20}$ But Thucydides also makes clear that Alcibiades lived beyond his means, always having greater desires than

18 Scott and Welton suggest that it is Alcibiades' desire to avoid shame that leads him to make his speech at the symposium, in order to knock down Socrates from his pedestal. See Gary Scott and William Welton, 'An Overlooked Motive in Alcibiades' Symposium Speech', Interpretation 24 (1) (1996), 70.

19 Corrigan and Gazov-Corrigan, Dialectic at Play, 163.

20 See D. Gribble, Alcibiades and Athens: A Study in Literary Presentation (Oxford: Oxford University Press, 1999), 14-15 and chapter 3. 
means to fulfil them. Thucydides even specifies that Alcibiades' excessive desires caused the downfall of the state when they made the multitude reject him (Thuc. 6. 15.3-4). ${ }^{21}$ Socrates in Alcibiades I, too, presents Alcibiades as enormously ambitious, desiring to make himself not only ruler of Athens, but also over all of Greece and most of Asia (104-5). ${ }^{22}$ At least one forensic work presents Alcibiades as a threat to the community on account of his overinflated sense of pride, as well as his $\pi \alpha \rho \alpha \nu o ́ \mu \iota a$ (lawlessness of desire). A fragment from Eupolis even jokes that Alcibiades ought to be credited with the invention of drinking alcohol in the morning (frag 385K-). ${ }^{23}$ Demosthenes in his Against Meidias seeks to associate Meidias with Alicibiades in order to encourage the jurors to punish him. He warns that in the past, the city tolerated and excused the 'insolence' of figures such as Alcibiades, with the result of threatening genuine democracy (143-6). Alcibiades is a man who tries to live without limit, always pushing against his own vulnerability, even while such living threatened the well-being of the city. His self-awareness of his vulnerability, while it exceeds that of many others at the symposium, still does not translate into action. When Socrates disappears and Alcibiades finds himself before a crowd again, he admits that his shame dissipates and worldly ambition returns. Alcibiades' downfall is that

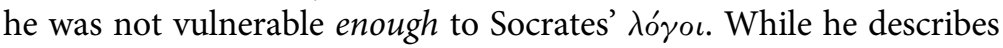
those arguments as biting words that wounded him, he flees $\left(\phi \epsilon v^{\prime} \gamma \epsilon \iota\right)$ from the source of the pain, rather than face it.

In Eros the Bittersweet, Anne Carson suggests that eros makes us aware of our own boundaries as limited human beings. When one feels eros for another, the desire to overcome separation and to become one with the object of one's love is impossible to realize: '[I]t is only, suddenly, at the moment when I would dissolve that boundary, I realize I never can. ${ }^{24}$ In the mix of desire for an impossible unity and awareness of one's own boundaries, the lover becomes more profoundly aware of her own limit. One temptation is to blur the line between the self and Other, or to consider the Other only in terms of how he or she can fill the lack in oneself. ${ }^{25}$ Perhaps this is

\footnotetext{
${ }^{21}$ Gribble, Alcibiades and Athens, 69-70.

22 Gribble, Alcibiades and Athens, 17.

${ }^{23}$ Gribble, Alcibiades and Athens, 79.

24 Anne Carson, Eros the Bittersweet (Champaign, Ill.: Dalkey, 1998), 30.

25 Carson, Eros the Bittersweet, 34-5.
} 
why Alcibiades feels such anger that Socrates treats him only as a father would a son, when he desires the touch of a lover. He is not simply frustrated that Socrates does not reciprocate his love. He seems to feel upset that Socrates as a person is not defined by Alcibiades' own need of him, which he admits to be substantial. Thus, he blames Socrates for not making him better than he is, in his illusory belief that Socrates' identity can be defined in terms of his own lack.

While Socrates and Alcibiades are both aware of their own limit, in a sense, Alcibiades will not claim his limit as his own. Perhaps this is the key difference between the two of them: Socrates takes on a kind of responsibility for responding to his own limit while Alcibiades expects others such as Socrates somehow to care for and to tend to those limits adequately. However, Socrates is right that there is a certain kind of aloneness, perhaps inevitably even loneliness, in taking on responsibility for one's weaknesses as well as strengths. Unlike the Aristophanic notion of a primal wound that can be healed if only the 'right' match is found, Socrates' picture of human limit and loving is not solved by another person's actions or presence, and perhaps not even soluble. Instead, Socrates emphasizes a constant attentiveness to the limits of one's own humanity and staying with one's responsibility to respond constructively to one's own limits.

The Phaedo puts it most starkly in Socrates' claim that all philosophy is 'practicing for death' (81a), the ultimate insoluble limit. The philosopher must not avoid the hard truth of death's inevitability, but rather live with the understanding that death is not something to be avoided at the expense of other goods. Socrates, then, while invulnerable to snow, money, bodily beauty, and status, is nonetheless one who places a great deal of emphasis on being vulnerable to the words and arguments of others. Indeed, his account of how the prophetess Diotima taught and corrected him provides a paradigm for the significance of receiving teaching from outside oneself and acknowledging the need to learn. ${ }^{26}$ Socrates does not say that he has made the ascent himself, only that Diotima has 'persuaded me' of the account of eros. ${ }^{27}$ While Socrates and Diotima were not lovers in a strict sense, they do fit the model of reproduction of beautiful ideas that Diotima

\footnotetext{
${ }^{26}$ Ionescu, 'The Transition from the Lower', 9.

27 William J. Prior, 'The Portrait of Socrates in Plato's Symposium', in Oxford Studies in Ancient Philosophy Vol. XXXI (Oxford: Oxford University Press, 2006), 147.
} 
sets out: Diotima has shared something of her knowledge of love's nature with Socrates, who recognizes his need for such a teaching. He describes his encounter with her as a matter of having been 'cross-

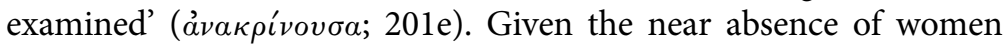
from political and philosophical discourse, the admission of being cross-examined by a woman, and found wanting, is particularly humbling. But Socrates' response was to learn, and to praise Diotima for her wisdom, not to get angry at his own insufficiency.

Further, in this conversation at the symposium, Socrates participates again in a conversation in which the knowledge is reproduced, again handed on to others, who may or may not respond to it with a sense of their own neediness (or its persuasiveness as an account). But it is Socrates' sense of his own limit, the 'knowledge of his own ignorance', that he characterizes as his 'true wisdom' in the Apology, a wisdom that makes possible both learning and passing on what he has learned, but a form of wisdom which also makes him vulnerable to the charges of those who feel humiliated by his questioning attempts to get others to feel their own neediness. This mode of questioning in order to make others understand their 'lack' will eventually contribute to his being put to death, but also to his creativity here in contributing to the ongoing discussion of love. ${ }^{28}$

Socrates' justice and Alcibiades' injustice are the respective consequences of different responses they each have to their own vulnerability. The previous chapter explored how in the Gorgias, Callicles sees Socrates' inattentiveness to political and pragmatic concerns as potentially harmful. However, the Symposium suggests that there are tremendous costs in too great a concern with political pressure. While Socrates' death is the consequence of choosing philosophy, a life of enquiry and of questioning of others, as his response, Alcibiades avoids his own vulnerability with the resulting peril of losing a sense of his own virtue. If we contrast Socrates' relative placidity and acceptance of his own death in both the Phaedo and the Apology, to the inner turmoil and confusion that we see in Alcibiades' speech, as well as the outward tumult of his political actions, Socrates' response seems to result in greater happiness. Indeed, his recognition

\footnotetext{
28 Socrates suggests that the real reason that others became angry with him was that they redirected their frustration at their inability to answer his questions at him: 'those who are examined are angry with me, instead of angry with themselves' (Apology 23c).
} 
of his limit seems to be the very source of his own freedom, for without fear of death or loss of status, Socrates can speak truthfully and authentically about all matters. ${ }^{29}$ Socrates' death is not something that he regards as evil, given that he has been as just as possible in the course of his life. In contrast, Alcibiades seems to struggle with the good of his own activities and his self-understanding, with peace never quite in reach.

But Socrates' response to vulnerability does not only have consequences for personal happiness as an individual. For this openness to language and its transformative potential is true also for some others in the dialogue. Dialogue is made possible because Socrates and

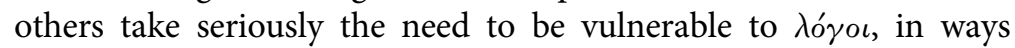
that Alcibiades refuses. Eros drives the philosophical conversation of this meeting of friends and acquaintances. For some of the same themes in the individual speeches about eros are recapitulated in this particular symposium's interactions in deed. While the flute girls have been sent away, and speeches have supplanted (at least to some extent) kisses and heavy drinking, after a previous night's excess (176a-e), eros still abounds at the party. Aristodemus attends the party because he is, according to Apollodorus in the dialogue's opening, 'obsessed' with Socrates. But Socrates is clearly not bothered by Aristodemus' attention; instead, he invites him along to the party, which only Socrates had been asked to attend. Because Socrates becomes lost in thought, Aristodemus ends up accidentally at the party without Socrates, and so experiences the awkward unpleasantness of being an uninvited guest. Eros itself is something like that experience, of being an 'uninvited guest'; such a moment takes us off guard, and interferes in the ordering of our best, most carefully laid out plans. This sense of eros as an interruption continues in the dialogue's action when Aristophanes gets the hiccups, and so Erixymachus takes over his place in the speechmaking. Alcibiades' sudden, drunken entrance is its most powerful interruption. ${ }^{30}$

Eros is also present in the philosophical conversation itself, in the mixture of Poverty and Plenty, $\pi \epsilon v^{\prime} \alpha$, and $\pi o^{\prime} \rho o_{\text {, }}$ in the quest to understand love's nature. Love is not only the topic of conversation;

\footnotetext{
29 Scott and Welton, 'An Overlooked Motive', 74-7.

30 Nussbaum points to the significance of the dialogue's dating as an allusion to Alcibiades' later mutilation of the hermai as well. See Nussbaum, 'The Speech of Alcibiades', 171.
} 
it is its motive, when we understand eros in its wider dimension as that which gives birth to, among other creative goods, beautiful speeches. These speeches also bind the participants in this conversation together, to one another, so that they are also like the lover and beloved of Plato's Phaedrus, whose love for each other leads to the sprouting of wings and ascent to that which they both love outside of one another. Diotima and Socrates might be one such pairing, as her questioning of him fruitfully contributes to his further growth and development. ${ }^{31}$ But instead of philosophy existing only between the lover-beloved dyad, the Symposium makes the whole community, whose speeches build dialectically upon one another in conversation, the means of the ascent. While Socrates can fall prey to his temptation to turn away from the world and its interactions, and get lost in his thoughts while leaving poor Aristodemus at the door, the larger community of philosophers and poets, doctors and politicians also ensures that he does not remain standing there in contemplation. The incompleteness, longing, and even wounded nature of souls such as Alcibiades ensures that Socrates remains an active part of the life of the community, not only a contemplator, but also as a moral and political actor, and friend.

31 Corrigan and Glasov-Corrigan note the importance of balance between the feminine and masculine, as well as between Diotima's Plenty and Socrates' Poverty, as creative forces in the dialogue. See Corrigan and Glasov-Corrigan, Dialectic at Play, 111-18. 
This is an open access version of the publication distributed under the terms of the Creative Commons AttributionNonCommercial-NoDerivs licence (http://creativecommons.org/licenses/by-nc-nd/3.0/), which permits non-commercial reproduction and distribution of the work, in any medium, provided the original work is not altered or transformed in any way, and that the work is properly cited. For commercial re-use, please contact academic.permissions@oup.com 


\section{6}

\section{Friendship and Moral Failure in Aristotle's Ethics}

Aristotle's account of friendship ( $\left.\phi \iota \lambda^{\prime} \alpha\right)$ extends over nearly two books of the Nicomachean Ethics, granting friendship a central place in his account of an ethical life. Aristotle writes, 'No one would choose to live without friends even if he had all the other goods' (N. Ethics 1155a). ${ }^{1}$ Whatever value Aristotle grants to the necessity of friendship for exercise of the moral and political virtues, his account of friendship is not limited to such necessity. Instead, we find Aristotle speaking of a true friend as a refuge in times of trouble; as a person whom we can trust; as one who knows one's self more deeply than anyone else; and in the best cases, even as 'another self'. Aristotle opens his account of pi>ía in Book VIII with a brief statement of its essentiality. He does not require that extensive argument be given for friendship's centrality to human nature, noting only that $\phi_{i \lambda} i^{\prime} \alpha$ is so basic to both our earliest bonds to our mothers and our most civilized and highly developed political institutions that its natural origin cannot be denied. Aristotle grants friendship the status as the noblest of human relationships, a relationship of not only necessity, but also honour.

Working out the details as to why Aristotle grants such centrality to friendship has been something of a puzzle for commentators, for Aristotle clearly claims that the virtuous man is by definition selfsufficient. Commentators have wondered about the relationship

1 Translations used for the Ethics in this chapter are from Aristotle, Nicomachean Ethics, trans. Terence Irwin (Cambridge, Mass.: Hackett, 1985). Greek consulted in Aristotle, Nicomachean Ethics, ed. J. Bywater (Oxford: Clarendon Press, 1894), accessed online at the Perseus Digital Library, <http://www.perseus.tufts.edu/hopper/ text?doc=Perseus\%3atext\%3a1999.01.0053>, 2010-12. 
between Aristotle's claim to the self-sufficiency of virtue, and his remarks about the centrality of friendship to a life well lived, given the contingencies involved in friendship. Cooper, for example, asserts that if the virtuous man does not need others in order to be virtuous, we might have little reason yet to understand why the virtuous man would even choose to make friendships of virtue. But Aristotle clearly makes such friendships essential to the flourishing of the human person. Cooper finds the answer in Aristotle's claim that friends help to increase our self-knowledge, for they show us a reflection of our own lives so that we might be able to study $(\theta \epsilon \omega \rho \epsilon \hat{\imath} \nu)$ it in another (Magna Moralia 1213a). Such self-knowledge is part of human flourishing. ${ }^{2}$ Nussbaum persuasively argues that relational goods such as friendship are both essential to human flourishing and yet inherently vulnerable to a variety of contingent circumstances that can diminish such relationships and the happiness that they bring. Friendship is central to human life, both because we are political beings by nature whose humanity is bound up with relationality, and because human virtues such as justice and generosity are by nature connected to human neediness. ${ }^{3}$ Generosity exists only as a virtue because we have need of one another's generosity as human beings who cannot flourish alone. Yet, a wide variety of contingencies make the development of such friendships difficult, such as the luck involved in finding another of high character and aspiration, or the ability to trust in others. Friendships can be lost to departures, distrust, and inevitably to the death of the other friend. ${ }^{4}$

Relatively little attention has been paid to Aristotle's discussion of how to respond to the moral failure of a friend. To the extent that this topic has been addressed, commentators have mostly focused on his discussion as an example of Aristotle's over-reliance on good character as central to true friendship. Some, for example, object that Aristotle requires far too much of friendships by eliminating the possibility of friendship with those who lack virtue. He even argues for the abandonment of a friend who no longer possesses virtue. However much it may be the case that Aristotle is not generous enough in his responsiveness to the good of loving the other in his imperfection, I would

\footnotetext{
2 John Cooper, Reason and Emotion (Princeton: Princeton University Press, 1999), 341-3.

${ }^{3}$ Nussbaum, Fragility, 350, $357 . \quad{ }^{4}$ Nussbaum, Fragility, 359-61.
} 
argue that Aristotle expresses a remarkable care and sensitivity for the genuine loss of such friendships. Aristotle's sensitive discussion of moral failures among friends deepens our understanding of his openness to the difficulties of human vulnerability in relationships. Indeed, his understanding of friendship accounts for a certain degree of contingency and even love of other individuals in their particularity that is not often emphasized in commentaries. ${ }^{5}$

I shall focus on Aristotle's account of how one properly reacts to the loss of a friend who has turned bad, in order to explore more deeply Aristotle's sense in which friendship extends mutual dependence and even increases our vulnerability to one another. ${ }^{6}$ Such vulnerability moderates somewhat his claims that the virtuous man is self-sufficient. While the good man is self-sufficient in virtue, his friendships not only are necessary for his full flourishing as a good person, but also leave him with genuine loss when such friendships come to an end. Aristotle's care for the selfsufficiency of virtue is also balanced by a realistic and sensitive acknowledgement of the virtuous man's vulnerability to loss in engaging in intimate relationships. Such loss includes not only the loss of another with whom to spend time and to exercise the virtues, but also the loss of the particular and irreplaceable nature of the friend as an individual.

I next argue that Aristotle's recognition of the relative limits of close friendships, family relationships, and even civic laws suggests his acknowledgement of human limits and the need to care for one another in the midst of human finitude. Precisely because no single set of relationships-including friendships of virtue-can provide for all human needs all the time, Aristotle emphasizes the need for multiple sources of care in community. We find in his discussion of friendship, then, a readiness to acknowledge human limits in

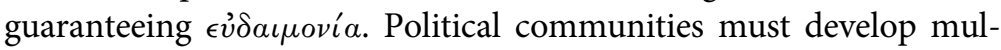
tiple forms of care if they are to be successful in developing good citizens.

\footnotetext{
${ }^{5}$ Here I am particularly thinking of Stern-Gillett's argument that Aristotle's notion of friendship centres on loving the rationality of another, thus excluding his particularity and contingent goods from what is loved in the friend. See Stern-Gillett, Aristotle's Philosophy of Friendship, especially chapter 3.

${ }^{6}$ Cooper also sees vulnerability, particularly psychological vulnerability, in such relationships. See Cooper, Reason and Emotion, 351.
} 
Friendship plays an important, though limited, role in ongoing moral development. Aristotle grounds all forms of friendship in our most basic human dependencies: '[T] he young need it to keep from error. The old need it to care for them and support the actions that fail because of weakness. And those in their prime need it to do fine actions; for when "two go together..." they are more capable of understanding and acting' (N. Ethics 1115a). While Aristotle goes on to argue that the best forms of $\phi i \lambda_{i} \alpha$ occur between two virtuous individuals, its origin lies in human weakness. Power, honour, and prosperity are all goods that are subject to risk, and the more that one possesses such goods, the greater the need when they are taken away. Childhood and old age, both times of weakness, are balanced by the strength of friendship. Even in the best part of life, with the fewest weaknesses, friendship is required: not only to have someone with whom to practise the virtues, but also someone with whom to discover how to live them.

Aristotle's above use of the proverbial 'two go together' refers to the events of Homer's Iliad in which Odysseus and Diomedes plan to spy on the Trojans to see how far the Trojans have advanced into Greek territory. Their mission takes place during a time of great Greek military risk, and so is especially fearful. Diomedes asks for a companion who might accompany them with the idea that two people are better suited to discover the truth, since an individual mind does not reach as far as two together. Socrates, in the Protagoras, quotes the same passage: 'Protagoras, please don't think that I have any other desire in our discussion than to examine the things that are difficulties for me each time. For I think that there is a great deal in what Homer says: "When two go together, and one sees it before the other." For somehow we human beings are all more resourceful ( $\epsilon \dot{v} \pi \circ \rho \omega ́ \tau \epsilon \rho \circ)$ this way, in each deed, word, or thought; but if someone observes something alone, he has to go around searching until he discovers somebody to whom he can show it and who will confirm it' (Prot. $348 \mathrm{c}-\mathrm{d})$.

Aristotle takes up the theme of 'resourcefulness' and extends it to the realm of friendship. In friendship, an individual who lacks something finds the means he needs to accomplish good action with the presence of another alongside of him. A friend provides not only concrete resources to accomplish ends (means for the elderly to 
survive, or good advice for the young); friendship also seems to enhance one's own internal resources. When Aristotle suggests that friends aid in both 'thinking and acting', the implication is that in the presence of a friend, one's own abilities are enhanced through the shared experience of pursuing a goal alongside another. For example, the presence of a courageous friend in the heat of battle not only protects another from bodily harm, but ideally also inspires the other to persevere and to continue to draw upon his own resources for courage in the face of a threat. Friendship provides for human need in a quite different way from material resources. While food satiates hunger and weapons preserve a threatened man's welfare, friendship does not merely fill a need. Instead, friendship cultivates the development of one's capacities. Virtues such as generosity, courage, and wittiness require others as models for learning how to cultivate and live such virtues in particular situations. But even once such virtues are firmly rooted in character, we need others with whom to be generous, courageous, or witty. The ongoing existence of such virtues as active parts of our lives requires others; nor can courage be a meaningful part of life unless my courage is exercised on behalf of others. To this extent, one's own happiness is fundamentally intertwined with the presence and shared activity of other friends, whose existence allows my own excellence (and also their excellence) to flourish. ${ }^{7}$

Nussbaum has argued for the centrality of luck or $\tau \dot{v} \chi \eta$ in Aristotle's ethical thought. While the life of virtue is stable and has some resistance to the experience of unlucky circumstances, this resistance is not endless. For example, one might say that a person in an irreversible coma as a result of a terrible accident is unlucky and unhappy. This is not to say that he or she lacks value, only that we can say there is something fundamentally missing from an unconscious life that makes it 'unhappy', or at least significantly unhappier than a

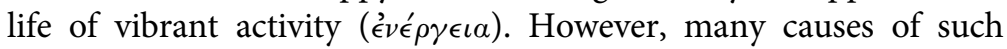

\footnotetext{
7 Annas argues that the primary good of a friendship of virtue is to contemplate the goodness of one's friend, on the grounds that the self-sufficient man has enough in his own virtue that he is not in need of others there. See Julia Annas, 'Plato and Aristotle on Friendship and Altruism', Mind 86 (1977), 532-54. However, since happiness includes the activity associated with the virtues, and not only their possession, to have others with whom to share this activity is central to our ability to do it more easily and more often. See also Julia Annas, The Morality of Happiness (Oxford: Oxford University Press, 1993), chapter 12. See also Cooper, Reason and Emotion, 345-51.
} 
unhappiness are beyond our control. Aristotle, in particular, was concerned with large upheavals in the community, such as those found in enslavement after lost wars, or political turmoil within one's own community. ${ }^{8}$

Friendship, too, is subject to luck, insofar as many factors can limit or end friendships. Aristotle emphasizes that friendships of virtue are less likely to come to an end than friendships of utility or pleasure, which remain only as long as the usefulness or the pleasure of the friend is of benefit. If two people are friends as a result of utility, for example, work together as study partners for a university class, and then the class terminates, the friendship itself must terminate, or else the reason for its continued existence must transform. The friends in question might find that they also share a common love of sports, and so continue in their friendship now as friends of pleasure. Or they may be in another class and so remain friends of utility whose primary relationship stems from the human dependence upon others to learn and to grow intellectually. Friendships of pleasure and of utility are less stable and lasting than other forms of friendship because the raison d'etre for such a friendship is likely to change. To this extent, they are incomplete forms of friendship. ${ }^{9}$

Aristotle understands friendships of virtue to be significantly less likely to change or to end, insofar as the reason for their existencethe pursuit of a life of moral excellence-does not terminate so long as both persons live. Moral virtue, by its definition, is a stable and abiding character, a characteristic of soul that takes much time to develop, but once established is unlikely to be lost. Nonetheless, Aristotle grapples with the possibility of a friendship in which one friend is faced with the moral failure of the other friend, a moral failure that tests the very resilience of friendship. Aristotle's explanation of the difficulties with deciding how philosophically to resolve this problem exhibits the complexity and nuance of his understanding of human dependency. Indeed, despite his claim that the best form of friendship displays 'complete' virtue, Aristotle exhibits a tremendous sensitivity to human moral weakness in his account of friendship.

Aristotle's notion of friendship is grounded in the premiss that human beings love only what is lovable, that is, that which is worthy

\footnotetext{
${ }^{8}$ Nussbaum, Fragility, 345.

9 Lorraine Smith Pangle, Aristotle and the Philosophy of Friendship (Cambridge: Cambridge University Press, 2003), 39.
} 
of love or appears to be so: 'For, it seems, not everything is loved but [only] what is lovable, and this is either good or pleasant or useful' (N. Ethics 1155b). The familiar typology of three types of friendship categorizes friendship according to what is loved about the friend, that is, whether he is useful to one's self, gives pleasure in being a friend, or is a good human being. While the first two forms of friendship are forms of love in which the object of friendship is loved for the sake of what is good for the one who loves; a friend who makes another laugh is pleasant and so is loved for how the character of wittiness produces a feeling of pleasure in oneself. In the case of perfect friendship, however, each friend loves the other because he is good-not only good for one's self, but also good in himself: 'Now those who wish goods to their friend for the friend's own sake are friends most of all; for they have this attitude because of the friend himself, not coincidentally. Hence, these people's friendship lasts as long as they are good; and virtue is enduring' (N. Ethics 1156b). Here Aristotle asserts an identity between the good of the friend for one's self and for the sake of the other. The good of the friend is not simply 'added on' to the benefit that one receives in friendship. Rather, his goodness is essential both to him and to why he is loved and lovable, namely, for himself. Although Aristotle emphasizes that virtuous friends are both pleasant and beneficial, what is loved in the virtuous friend is his selfhood, which in a deep way is constitutive of the human person. ${ }^{10}$

Unlike later models of ethical behaviour, such as Kant's ethical theory, which locates the good of the self in a single faculty such as the will, Aristotle's understanding of what it means to be good permeates the whole of human nature. Book I, particularly Chapter 7, lays out

${ }^{10}$ In contrast, Dale Jacquette argues that even friendships of virtue are good primarily because of the personal benefit that results in having them, for example, through encouraging the growth of one's own virtue. Peter Drum instead argues that Aristotle understands $\phi i \lambda_{i} \alpha$ in friendships of virtue to serve 'the good' and sees good friendships as part of loving the good. But for Aristotle, the very point of virtuous friendship is that love of the good and love of the friend coalesce: in loving a person who is truly an exemplar of what it means to be human, I love the good in him. To suggest that loving him is a means of loving 'the good' introduces an element of Platonism foreign to Aristotle's understanding of the good as inhering in particular types of beings, and even in relations between these beings. See Peter Drum, 'What is the Motivation of Morality for Friendship in Aristotle?', Journal of Value Inquiry 37 (2003), 97-9 and Dale Jacquette, 'Aristotle on the Value of Friendship as a Moral Motivation’, Journal of Value Inquiry 35 (2001), 387. 
the Aristotelian model of excellence as grounded in the fulfilment of human nature. Just as excellence in a plant lies in the good functioning of its nutrition and growth, and animal excellence lies in sense perception, to be a person of virtue requires that one exercise one's work, or "' $\rho \gamma o \nu$, one's activity, in a way that is fulfilling of a distinctively human existence. To this extent, perfect friendship possesses a complete harmony of love of the other for his virtue, but also for himself, for the two are identical for Aristotle: to be good is to be most fully and authentically human. Given that the friend who loves is also a person of virtue, he loves what is good by his own nature. As Annas has argued, Aristotle argues that to be $\phi$ i $\lambda$ avios (self-loving) is to be virtuous, insofar as the man who is becoming virtuous comes to love his true (i.e. virtuous) self more and more, and to love less virtuous aspects of himself less and less. ${ }^{11}$ Thus, in friendships of virtue, there is a tight unity between the good; the friend's good; and the fulfilment of one's own desires.

For this reason, wicked men cannot be friends for long, since their love lacks both steadfastness and completion. Aristotle attributes the inconstancy of friendship between wicked persons to an internal lack of steadfastness of desire, 'since they do not even remain similar to what they were', but are changeable in what sorts of objects of desire are pursued (N. Ethics 1159b). In such cases, there can be no unity of the fulfilment of one's own aims and objectives and the true love of another for himself, for the wicked man by definition does not love that which is truly good, but only that which is apparently good in his own eyes. Even if two friends share a common aim, there are constant threats to the persistence of such friendship. Take the example of two wicked men who work together in order to rob a bank. Those who lack virtue are likely to betray one another, for they do not possess constancy in courage, generosity, pursuit of honour, or the other virtues. In addition, the friendship exists for the sake of the achievement of some other good external to the friends, not the friend's own good. Once the money has been stolen, one easily imagines that one thief may wish to 'take the money and run' now that the friend does not continue to be useful. Even those who delight in one another's wickedness are not likely to remain friends for long, for such delight will be short-lived. Fundamentally, Aristotle's conception of the virtue is that it alone provides for lasting and complete pleasure. While

11 Annas, Morality of Happiness, 261.

This is an open access version of the publication distributed under the terms of the Creative Commons AttributionNonCommercial-NoDerivs licence (http://creativecommons.org/licenses/by-nc-nd/3.0/), which permits non-commercial reproduction and distribution of the work, in any medium, provided the original work is not altered or transformed in any way, and that the work is properly cited. For commercial re-use, please contact academic.permissions@oup.com 
superficially other kinds of goods might provide short-term pleasure, only 'real' goods allow for the lasting pleasure that the human being seeks. While Aristotle does not reduce pleasure to the good, he does regard pleasure as that which 'completes' the good. ${ }^{12}$ Thus, the vicious who cannot participate in the highest forms of friendship also lack the most significant and lasting pleasures of life.

However, a deeper set of issues arise when only one friend in a pair of apparently virtuous friends turns out not to be good. Aristotle asks what he takes to be a difficult, but common, question: 'But if we accept a friend as a good person, and then he becomes vicious, and seems so, should we still love him?' (N. Ethics 1165b). Aristotle's answer is complex and exhibits especially well the difficulty with the problem of moral education, given human vulnerability to harm from those who lack virtue. Aristotle's most basic answer is that 'what is bad is not lovable', but only that which is good (N. Ethics 1165b). Philosophically, Aristotle understands the human person to be capable only of loving what he understands or opines to be good. What is bad is not lovable by us, unless we mistakenly believe it to be good. Therefore, it is not possible to love an evil man, if one is good, for one will love the good and not the evil, according to one's own character. Nonetheless, in his additional remarks, Aristotle expresses hesitancy as to whether such careful and neat philosophical categories can capture the full extent of the experience of choosing whether to continue in friendship with a friend who repeatedly fails morally.

One consideration is whether one might have an obligation to love someone who is not good. Aristotle argues that if a friend has become bad, but not incurably so, we have even more of a duty to assist him than before his failure: 'If someone can be set right, we should try harder to rescue his character than his property, in so far as character is both better and more proper to friendship' (N. Ethics 1165b). Indeed, Aristotle suggests that the true friend will only abandon the relationship when it becomes clear to him that there is no possibility of its restoration, in which case it is understandable if he gives it up. However, such a loss is understood to be difficult; even in cases where the virtue of one person leaves behind the other, Aristotle says that in

12 David Bostock, 'Pleasure and Activity in Aristotle's Ethics', Phronesis 333 (1998), 251-72; Peter Hadreas, 'The Functions of Pleasure in Nicomachean Ethics x 4-5', Ancient Philosophy 24 (2004), 155-67; and Gary Gurtler, SJ, 'The Activity of Happiness in Aristotle's Ethics', Review of Metaphysics 56 (June 2003), 801-34. 
memory, a kind of $\phi \imath \lambda i$ a continues, as a friend will keep a 'memory of the familiarity they had', as a sign of what the friendship once meant to each person (N. Ethics 1165b). Aristotle's statement here is quite important, for it shows that the intimacy of the friendship is itself a good, and not only the qualities that the friend possesses or once possessed. Memories of past friends continue to have significance for us because of the intimate connection enjoyed, as well as for the particular qualities that our friends had.

Aristotle here points to the interdependency of happiness in the context of friendships of virtue. Friendships of trust and shared living, in which another's self is the primary object of love, affect the development of the virtue of the one who loves (and who is loved). Positively, this means that two friends of virtue can support one another in living well and reinforcing their mutual love of what is virtuous, and their ongoing virtuous action as exhibited in moral and intellectual virtues. ${ }^{13} \mathrm{~A}$ wicked person can also influence another's character, though perhaps is less likely to do so in the case of a person of fully formed virtue, who will not be inclined to alter since he is (by definition) of a firm and unchanging character.

Aristotle also denies the possibility of loving a bad man in his badness. If one means that one friend ought to love an evil friend, even in his evil, no such duty can be possible, for it is not a duty to love evil. Indeed, there is not a simple absence of such an obligation, but in fact a positive danger that might arise were one to love even the wickedness in a wicked man. Aristotle asserts that 'we ought neither to love what is bad nor to become similar to a bad person, and we have said that similar is friend to similar (N. Ethics 1165b).' That is, insofar as we love what is evil, the evil object of love does not only reflect an ongoing distortion of desire. To love an evil object can also seemingly become a cause of further distortion of desire in oneself. If a man loves a wicked person, Aristotle implies, the love of a wicked object makes the lover like that which he loves, that is, potentially more akin to the wicked man whom he loves. Thus, it might be necessary for the sake of one's own flourishing to end a relationship with another who threatens it-even a former friend.

And yet, Aristotle also takes pains to emphasize the genuine experience of loss in the end of such a friendship. In lesser forms

13 Annas, Morality of Happiness, 251-2.

This is an open access version of the publication distributed under the terms of the Creative Commons AttributionNonCommercial-NoDerivs licence (http://creativecommons.org/licenses/by-nc-nd/3.0/), which permits non-commercial reproduction and distribution of the work, in any medium, provided the original work is not altered or transformed in any way, and that the work is properly cited. For commercial re-use, please contact academic.permissions@oup.com 
of friendship, because less of the self has been offered to the friendship, the loss at its termination is accordingly less deeply felt. ${ }^{14}$ In the case of a friendship of virtue that dissolves when one of the friends is seen to lack virtue, one has lost not only someone of pleasure or of use, but 'another self' ${ }^{15}$ Here, the philosophical tensions inherent in the term 'another self' become especially apparent. As Stern-Gillett has argued, the idea of a friend as another self raises difficulties with the notion of selfhood. ${ }^{16}$ How to characterize the idea of the friend as also one's self is notoriously difficult. In the Magna Moralia, the friend is presented as like a mirror, which reflects back to us something about one's self, since one cannot see the self without it (1213a). However, if the 'other self' is only a mirror that reflects one's own characteristics back to one's self, then the other seems only to be loved for selfish reasons, and not 'seen' at all in his otherness and independence, as the seat of his own moral actions and choices. If the other friend is truly 'another', then there must be a sense of separateness of each friend. Distinctness of some sort is required for relations to exist, for without two independent persons, no relation between them can come to be, only the use (or misuse) of one by another.

One way to resolve this difficulty is to focus on the friends' shared activity and shared goals as constitutive of their bond. As two people walking on a path to a common destination are unified by their common goal and method of attaining that goal, friends of virtue participate in shared activity $\left(\dot{\epsilon}^{\prime} \nu \epsilon^{\prime} \rho \gamma \epsilon \iota \alpha\right)$ as part of the pursuit of a good life. ${ }^{17}$ Still, solely attending to their shared activity also misses something of the intimacy that Aristotle wishes to communicate through the phrase 'other self': a friend who is somehow both 'other' and yet also so intimately loved that the boundaries between care for self, and care for other, are not fixed and firm. Thus, one friend wishes to assist another, Aristotle says, not only for one's own sake, but rather for his sake (Rhetoric 1380b-1381a). ${ }^{18}$ Moreover, the friends' love for one another is not simply a reflection of their love for the good. Aristotle emphasizes that no one would wish for his friend to become

\footnotetext{
14 Pangle, Friendship, 50.

15 Thus, Annas says, when a friend is lost upon death or leaving town, we naturally feel exposed. Annas, Morality of Happiness, 252.

16 Stern-Gillett, Aristotle's Philosophy of Friendship, chapter 1.

17 Pangle, Friendship, 146.

18 Stern-Gillett, Aristotle's Philosophy of Friendship, 59.
} 
a god, but only to be as happy and virtuous a human being as a human being can be (N. Ethics 1159a). ${ }^{19}$ Thus, Aristotle suggests that one loves a friend not as an embodiment of perfection, but as a human being, even when one takes into account the limited nature of another's humanity.

Annas has argued that one strong motivation for the love of another in his goodness is that it allows us to contemplate ( $\theta \epsilon o \rho \epsilon \hat{\imath} v)$ the good in another, since to do so in another is easier than to do so in oneself (N. Ethics 1168b2-4). ${ }^{20}$ One difficulty with such a view is that it seems to make the beloved lovable only insofar as he 'shows' the good to us. This would seem, then, to make the good, but not the friend himself the real object of love. Annas suggests limitedness in Aristotle's approach to friendship on these grounds. She writes, 'Aristotle is wrongly insisting that friendship involves approval of and respect for the friend's character, and ignoring the irrational element in friendship, which can lead us to like and love people of whom we strongly disapprove. And to the extent that he runs these ideas together, he could be said not to have fully attained the notion of loving someone truly as an individual, rather than as a bearer of desired qualities. ${ }^{21}$ However, Aristotle's discussion of the loss of a friend who has become bad shows that there is something much more in the loss than the grief associated with, for example, fewer opportunities to contemplate the good for oneself. For Aristotle's claim that one ought to come to the assistance of a friend more than a nonfriend because of the intimacy of the friendship conveys the significance of intimacy as a good of friendship. The friend is not loved for his qualities alone, but also as one with whom one has shared past activity and with whom one has shared oneself.

Stern-Gillett argues that the 'other self' loved in a perfect friendship is limited to the rational self. Her argument relies upon the development of the notion that practical virtue is the 'hub' around which the rest of the self is formed; to the extent that practical wisdom is responsible for the ordering and arrangement of the person's self, the Aristotelian 'self' is such a rational faculty. ${ }^{22}$ She writes, 'Since human beings are to be identified with their nous, those who fail to be rational will correspondingly fail to be fully themselves. To that

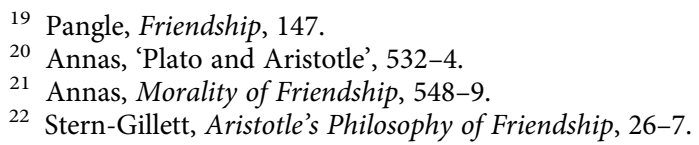


extent, they cannot be loved in themselves. ${ }^{23}$ And yet, we find this claim difficult to maintain in the light of Aristotle's description of the centrality of memory in cases of friendships lost to moral failure. As I will argue below, Aristotle's account of memory allows for a kind of retention of the friendship. The presence of a friend in memory and the development of a narrative about the meaning of the lost friendship preserves the care present in the friendship, as well as retaining elements of the vulnerability therein.

Aristotle's description of the centrality of memory as a mechanism for maintaining a connection to a lost friend, even after the friendship has been dissolved, suggests a different object of love from the friend's virtue alone. Indeed, that Aristotle finds a need for a coping mechanism at all suggests that the love of a friend who was once good, but now is not, involves much more than a mere intellectual assent to the friend's good, or a regret about the loss of an abstract good (for example, regretting the mere loss of having around oneself a good friend). Memory becomes an important faculty for dealing with such losses because such losses are not limited to the loss of an abstract good, nor even to a disinterested regret on behalf of the friend (e.g. sorrow that he no longer has the good for himself). Instead, in the loss of 'another self' one finds the loss of some portion of one's own selfhood.

What is beloved in the memory of the lost friendship is not only the recollection of how the friend once exhibited virtue, though this might well be part of such a memory. Nor is there simple regret of the contrast between the past good and the present lack of such a good in the friend, though again this sense of loss might be part of such a memory. Instead, Aristotle claims that the memory of the past experiences of the self and one's lost friend are to form a part of one's present love for the friend. Why might such care for memory be of such importance?

One reason might be that the memory of the friend's past goodness continues to inform the present attitude toward the friend as a greater whole than his current character and lived action seem to embody.

23 Stern-Gillett, Aristotle's Philosophy of Friendship, 41.

This is an open access version of the publication distributed under the terms of the Creative Commons AttributionNonCommercial-NoDerivs licence (http://creativecommons.org/licenses/by-nc-nd/3.0/), which permits non-commercial reproduction and distribution of the work, in any medium, provided the original work is not altered or transformed in any way, and that the work is properly cited. For commercial re-use, please contact academic.permissions@oup.com 
While others might regard the friend's current activity-for example, bad behaviour in the midst of an addiction-to be the whole of the friend's selfhood, the Aristotelian emphasis on memory serves to connect his current deficiencies to a larger picture of the friend in his wholeness. While those who lack deep knowledge of the friend might regard his current activity as indicative of his entire nature, the former friend of virtue can understand a larger context and may even be able to contextualize the friend's shift of character in terms of a larger narrative that is lacking for those who do not know the friend well. For example, a friend who behaves poorly as a result of a reaction to a traumatic experience (as in a wartime trauma), but who has been known to be brave or generous in other circumstances, is not reducible to his current behaviour. His life as a whole communicates a different reality from what his current activity or character seems to do. Memory allows for the possibility of an overarching narrative about the friend that incorporates specific moments in the person's life into a larger meaningful whole.

Likewise, the indeterminate future makes an evaluation of the goodness of a person's life difficult to evaluate once and for all, although a virtuous man's character is more likely to be stable and consistent (N. Ethics 1101a-b). Just as past exemplary actions of a friend's once-good character make current judgements of his worth incomplete, so too does the friend's current bad behaviour not limit his future behaviour entirely. Memory of the friend provides a greater context for a more accurate, and more generous, understanding of the lost friend's worth and the possibility of his future self's virtue.

The presence of memory as significant in Aristotle's account of lost friendship also suggests that the particularity of the friend is crucial in the care experienced after loss. Memory itself is not a faculty of nous, Aristotle argues in 'On Memory and Reminiscence'; instead, memory essentially belongs to the faculty of sense perception. The person who, in a sense, continues in friendship with his friend through the faculty of memory relies on his prior sense perceptions, and not only upon an intellectual judgement that his friend was good or could be good again. If memory focuses upon sense perception, then one would expect Aristotle to include among such memories of friendship particular contingent experiences of the friend-experiences that were specific to the pair, and not only memories of general characteristics that the friend once possessed. For example, there is a significant difference between remembering abstractly that my friend once used 
to be 'generous', but now has become rather closed in upon himself, and recollecting particular moments of generosity that I witnessed him exhibit, such as when he offered to buy a meal for an individual who lacked the means. An old shared joke takes on a distinct and particular value among friends that exceeds the way in which the joke exemplifies the virtue of wittiness. Such shared experiences are 'excessive'; that is, their value exceeds the way in which the event exhibits an abstract judgement about the good. Instead, such experiences are constitutive of the goods shared in friendship, which are concrete and lived experiences known through sense perception and recollected through memory's revitalizations of such experiences.

Indeed, memory and narrative together tend to reshape and to reformulate the value of such experiences: a joke told many times among friends, or word play understood only among intimates who understand the reference, has a deeper value than a similar joke outside of the context of its presentation in friendship. The memory of such witty moments becomes a reminder of the past bond of friendship and of the particular moments shared in friendship. Thus, even if one's current love for a friend diminishes when a friendship ceases, nonetheless, not only his past virtue as an objective attribute of him, but also, particular past, contingent moments in a virtuous friendship remain alive in memory and in narrative retellings of the experience. Thus, Aristotle emphasizes in his discussion of memory that it is not merely a case of contemplating my own experience. I also possess an awareness of the object of contemplation as a presentation of the other (real) object:

Just in the same way we have to conceive that the mnemonic presentation within us is something which by itself is merely an object of contemplation, while, in relation to something else, it is also a presentation of that other thing. In so far as it is regarded in itself, it is only an object of contemplation, or a presentation; but when considered as relative to something else, e.g. as its likeness, it is also a mnemonic token. (On Memory and Reminiscence 450b) ${ }^{24}$

In other words, memories are not Cartesian inner experiences, nor are they simply reproductions or copies of past experiences. Ordinarily, memories are understood by the subject to be tokens of the original

\footnotetext{
24 Translation of On Memory and Reminiscence from The Basic Works of Aristotle, ed. Richard McKeon (New York: Random House, 2001), translations by Rhys Roberts and Ingram Bywater.
} 
object to which the memory has a likeness, if not identity. In the case of friendship, a memory of my friend is not merely a re-experiencing of my own affection or knowledge of her, or what I knew through her, but rather the memory about her, in her very being. Thus, Aristotle's emphasis on memory in the case of lost friendship indicates the importance of faculties other than vovs in the love extended in friendship; sense experience, memory, and other faculties not only work in the present moments of friendship, but also continue to play a role in the meaning of the friendship long after the friendship itself may have ceased.

Indeed, because the activity recalled through memory is often shared activity, whenever I remember a past incident with my friend in which I also shared, my own selfhood is also the object of reference. Memories of friendship are both mnemonic tokens of another and of one's self in relation to the other. Practical activity, exercise of my human faculties, takes place not only alongside other rational beings, but also with and in relation to them in a strong sense. Memories of those activities constitute a part of my selfhood. To some extent, it can even be the dissonance between one's past memories of a beloved friend and one's self, and a current lack of friendship that inevitably cause the grief, pain, and especially sense of loss of one's self within the current grief. In such experiences of loss, one beholds not only a lost friend, but also an aspect of one's self that has been lost. For, the present moment cannot match past memories of shared experiences of $\phi i \lambda_{i}^{\prime} a$, and yet the latter are still present as 'reminders' or tokens of what has been lost. Indeed, to the extent that memory memorializes the lost friend, it also keeps present the vulnerability experienced in the loss itself. However, memory also can assist in positively reconstituting the meaning of the loss, as in the case of developing a narrative about my friend's larger experiences, or in using memory as grounds for hope that he will eventually live better.

Rather than characterizing the notion of the 'other self' as a logical paradox, the phrase might best be understood as communicating a truth about human interdependence: namely, that those closest to us in friendship both dissolve some of our sense of independence and separateness as we come to care for them, and yet always maintain a degree of alterity that shows us to be distinct beings whose characters, choices, and preferences can veer away from our own. ${ }^{25}$ In the case of

${ }^{25}$ Nussbaum, Fragility, 351.

This is an open access version of the publication distributed under the terms of the Creative Commons AttributionNonCommercial-NoDerivs licence (http://creativecommons.org/licenses/by-nc-nd/3.0/), which permits non-commercial reproduction and distribution of the work, in any medium, provided the original work is not altered or transformed in any way, and that the work is properly cited. For commercial re-use, please contact academic.permissions@oup.com 
friends of virtue who find that one friend has repeatedly failed morally, such alterity suddenly comes to light, replacing the sensibility of connectedness and shared 'selfhood' that had been experienced until the discovery. In friendships of virtue that are going well, the harmony between oneself and the other is a source of ongoing pleasure. While the otherness of a friend can delight by its complementarity, such alterity is held in balance with a sense of abiding and shared values. The otherness of the other friend is not a threat, but a welcome addition to one's own range of experiences and interests. However, when major differences of value appear, and indeed, these values concern not mere preferences (for example, for sports or musical interests), but affect deeply held conceptions of the good life, the friend's alterity suddenly comes into relief. Indeed, in the case of a friend of apparent virtue who now reveals himself to be capable of major, repeated moral failure, the possibility that one's true self will no longer be fully received in friendship also becomes apparent.

The decision to leave a friendship when one's friend has repeatedly failed morally, when his character seems to be beyond repair, is not only a practical decision for a friend. Such a decision involves genuine loss for him, even if the decision is right. It is not simply that the person with whom one wishes to share activity, to develop one's virtues, and to enjoy for himself is no longer there. One's sense of trust is also diminished. Aristotle suggests that older people can so often suffer such losses that in time, many older individuals are shaped by a pervading sense of distrust for the imperfections of human nature (N. Ethics 1157b-1158a). Such distrust diminishes their capacity for happiness, but Aristotle does not suggest that their judgements are thereby mistaken. Rather, along with the great possibilities for happiness that intimate friendship opens up, so too is the possibility of diminished happiness brought on by repeated loss or betrayal.

Contemporary theorists have conceptually distinguished trust from reliance: while reliance implies only a belief that another person will follow through on a particular activity-for example, providing money for a trip home, or showing up to teach a class-trust implies a great set of interpersonal attitudes that guide one's very orientation toward being in relationship. ${ }^{26}$ Trust can involve, for example, a belief

${ }^{26}$ Margaret Walker, Moral Repair (Cambridge: Cambridge University Press, 2006), 74-5. 
in the other person's good will and integrity, a disposition to interpret the other's actions favourably when they are in doubt, and an 'entrusting' of one's vulnerabilities to another with the expectation that they will be reliably received. ${ }^{27}$ Aristotle's conception of friendship requires that trust be built up in order for perfect friendship to develop, precisely because the self is being entrusted to another. It is not only the promise of shared activity, or shared conversation, that takes place in the promise of friendship, but also the choice to give over oneself to another and to receive the other as 'another self' that requires such trust. Violations of trust, then, are also felt to be violations of the self, or at least of belief that one is valued as 'another self' to another, and can reliably be entrusted to the other, in the context of friendship. Such violations are not escapable, but instead part of the human condition. While Aristotle advises that friends must share many meals together before trust is given, his advice is descriptive and not prescriptive. The development of trust is dependent upon many factors, including one's own past experience, and can only arise when the right conditions are met. To this extent, Aristotle values a balance between self-sufficiency and dependency that takes account of ongoing human vulnerability in friendship.

\section{III}

The interdependency of human beings in moral development poses another kind of paradox for Aristotle, one with social and political consequences. For, if the goodness of one person can profoundly reinforce and even assist those still growing in virtue, then there would seem to be a duty to assist another person, even a wicked person, in growing to become a better person. As we have seen, such assistance potentially poses dangers for the friend who takes on this task, if it detracts from the good of his own virtuous and lived activity or simply seems impossible to accomplish. But because the development of virtue depends on others for its very possibility, there ought to exist some social resources that would allow a man who has morally

27 Walker, Moral Repair, 74-9.

This is an open access version of the publication distributed under the terms of the Creative Commons AttributionNonCommercial-NoDerivs licence (http://creativecommons.org/licenses/by-nc-nd/3.0/), which permits non-commercial reproduction and distribution of the work, in any medium, provided the original work is not altered or transformed in any way, and that the work is properly cited. For commercial re-use, please contact academic.permissions@oup.com 
failed to regain his character. Virtue is far more important than property. And yet, the presence of such a vicious or incontinent person in public life also produces problems for the flourishing of the community, and especially for those with whom he is in closest relation. A former criminal, for example, who especially needs social resources that might lead him to live better, is also a potential threat to that community; and yet, to exclude him from participation within society and its goods is likely to make him grow worse, not better.

Here Aristotle recognizes a deep problematic in the nature of the development of virtue: to become good is partly a matter of personal responsibility, but also partly conditioned by those with whom we surround ourselves. In the case of a man who already lacks virtue, the only real possibility of his reform lies in exposure to and education by those who possess virtue. This is especially true in the case of the vicious, who believe what is bad to be good, and so lack an understanding of the good, not only an ability to follow through on it in action. However, those who possess virtue, seemingly, will not love those who lack it, for by their character they only love what is good and wish to pursue the good along with other good people. At most, they will only love the other for who he or she might someday become, or who they once were, but not for their currently bad state. Aristotle thus encounters the problem of how and whether friendship or other analogous relationships can sufficiently address the need for the community to engage with those who lack virtue.

At the purely theoretical level, Aristotle's account of friendship is consistent. To understand the end of what had seemed to be a friendship of virtue, on account of a friend's repeated moral failures, one friend need only see that the other was not the virtuous person he was believed to be. The virtuous friend who had loved, discovers that the beloved friend is, in fact, not even the person he had at first thought him to be. When the formerly good man is now seen to be bad, that person's self is no longer identical to the person who was once the object of $\phi \imath \lambda_{i} a$. Indeed, for Aristotle, one can not love what one does not understand to be good. Even in the case of a friend hesitant as to whether to continue a friendship with one who has failed morally, the remaining love for the friend concerns what is still good or lovable about him. ${ }^{28}$ For example, a drug addict working to

28 Cooper argues that friends love one another for moral properties of character; in his view, such motivation does not make friendship utilitarian, for a person's character 
turn around his life and live cleanly is loved not for his drug addiction, but rather for his potential for living better. To this extent, Aristotle is not inconsistent in his account of virtuous friendship.

However, the notion of moral failure in friendship raises an additional practical and political problem, namely, how societies are to care for those who fail at a moral level when rehabilitation of such character depends upon engagement and the care of others who surround them. In other words, if we are vulnerable to harm from those who lack virtue, and yet also ought to care for the cultivation of virtue in others more than any other good, then vulnerability to harm becomes a political and ethical problem. For Aristotle, to be selfsufficient ( $а v^{\prime} \tau \alpha \rho \kappa \epsilon s$ ) also means to live a life among family, friends, and fellow citizens (N. Ethics 1097b7-11). ${ }^{29}$ However, no one of these types of relationships alone suffices for the expression or development of a virtuous and happy life. Particularly when it comes to the question of moral development or rehabilitation, we find in Aristotle a continual need for dialectical interplay between the role of the family and of the law for the possibility of establishing virtue in its citizens. Neither resource is adequate alone, and each one is subject to the possibility of misfortune. For Aristotle, the role of parents is significant, but limited, insofar as moral development continues long past the period of childhood or formal education (N. Ethics $1103 \mathrm{~b}$ ). The role of law, while commendable, is also limited in the extent to which it can shape virtue.

In Book X of the Ethics, Aristotle emphasizes the importance of laws that can reinforce the nurture and the earlier habits of temperance provided by parents (N. Ethics 1180a). Such laws are crucial to education itself, since the city's flourishing requires that all of its citizens have a similar orientation to the civic good, rather than the happenstance education that any given parent might choose on his own for a child (Politics 1337a). Without some shared idea of the goal of education for children, individual moral upbringing cannot be harmonized into a civic morality. ${ }^{30}$ Such goals need to be continually lived out in the course of adult relationships as well, so that the law continues to assist its citizens in their moral development by setting

is essential to his being in a way that utilitarian goods are not. See John Cooper, 'Friendship and the Good in Aristotle', Philosophical Review 86 (1977), 290-315.

29 Nussbaum, Fragility, 344-5.

${ }^{30}$ Nussbaum, Fragility, 346. 
the proper conditions for the cultivation of good habits (N. Ethics 1180a).

The law, however, is imperfect as an instrument to shape moral growth, insofar as it can chastise those who are bad, but cannot provide the bonds of natural affection and individual attention to a specific person's needs that take place within the context of a family. Just as a doctor can best address an individual's illness by attending to the particulars of his illness, a person with moral deficiencies requires attention to his particular circumstances, which the law in its generality cannot legislate (N. Ethics $1180 \mathrm{a}-\mathrm{b}$ ). To this extent, the law is a second-order kind of institutional 'insurance' for the moral education of its citizens. The law can legislate how to educate children, but does not itself act as the primary educator. The law can punish those it deems to need fear as a motivator against bad action, but cannot single-handedly cultivate good internal motivation to seek the good and to reform one's habits. But the sorts of resources that can provide such motivations-family, friends, political peers, and smaller communities within the $\pi{ }^{\prime} \lambda_{\iota s}$-are even more subject to $\tau \dot{v} \chi \eta$ precisely because of their more intimate nature. The family and class to which one belongs, the education one receives, and the stability of the political parties that might support such education are subject to chance and prone to instability. And yet, it is precisely the interdependent nature of the human being that both leads to such vulnerability to luck, and also vulnerability that makes $\phi \iota \lambda_{i} \alpha$ and other love relationships possible in the first place.

Moreover, certain moral states seem to arise not only from the influence of education, but also from luck. For Aristotle, the brutish state, one step below vice, in which there is hardly even a moral sensibility, seems to be a result of bad luck. He writes, 'some bestial features also result from diseases and deformities' (N. Ethics 1145a), such as the cases of a slave who ate the liver of another fellow human being ( $N$. Ethics 1148b), indicating that the brute is not brutish or amoral by virtue of his own choice, but as a result of a defect. We can therefore say that the case of the brute is less evil, but more alarming, precisely because no choice is involved (N. Ethics 1150a). Even the incontinent man who is incontinent by virtue of strong passion is overcome by his bodily state, and akin to a person who is asleep, mad, or drunk. Aristotle explains the possibility of incontinence in a state of knowledge as acting in the presence of perceptual knowledge (such as 'this is sweet' and 'sweet things are pleasant to eat'), rather than in 
the presence of universal knowledge ('Sweet things are unhealthy'). But although Aristotle mostly emphasizes that incontinence is the result of many habitual incontinent acts, he also allows for the possibility that some forms of incontinence may be present from birth:

Incontinents through habituation are more easily cured than the natural incontinents; for habit is easier than nature to change. Indeed the reason why habit is also difficult to change is that it is like nature, as Euenus says: 'Habit, I say, is longtime training, my friend, and in the end training is nature for human beings.' (N. Ethics 1152a)

Aristotle thus suggests that there are at least two obstacles to moral freedom, two different types of vulnerability to moral weakness: the presence of incontinence from birth, or from a state that, after enough time, so resembles the inborn state that it is immutable, though it may not have once been so.

For Aristotle, the family is natural, and the procreative bonds and relations between couples, parents, and children are found even in the animal world (N. Ethics 1162a17-19). Parents seem to love their children with an intensity that is unmatched in other forms of relationship, while children owe their parents a debt that cannot be repaid ( $N$. Ethics $1161 b-1163 b)$. However, the family alone is limited in the moral and social goods that it can provide, while the $\pi$ ó $\iota_{\iota s}$ provides for the possibility of not just living, but living well (Politics 1252b12-13). ${ }^{31}$ The family, while attentive to the needs that individuals have of one another in certain respects, is itself limited and partial in its possibilities. The $\pi{ }^{\prime} \lambda_{\iota s}$ is not merely a collection of families and associations, but rather a greater whole that offers more than the sum of its parts. The $\pi$ ó $\lambda_{\iota s}$ offer its participants not only the advantages of laws and of extra-familial connections, but also opportunities for magnanimity, shared religious-political experiences, and the intimate connections between others found in friendships of virtue and even friendships of pleasure.

Moreover, the care that any given family provides is limited by the virtues and abilities of the parents, who may themselves be limited in the moral structure and nurture that they can provide for their children. As the contemporary ethical theorist Gheaus has suggested, we might consider such care to be a primary good that limits the possibility of political egalitarianism, as advocated by political

31 Pangle, Friendship, 86-7.

This is an open access version of the publication distributed under the terms of the Creative Commons AttributionNonCommercial-NoDerivs licence (http://creativecommons.org/licenses/by-nc-nd/3.0/), which permits non-commercial reproduction and distribution of the work, in any medium, provided the original work is not altered or transformed in any way, and that the work is properly cited. For commercial re-use, please contact academic.permissions@oup.com 
theorists such as Rawls. ${ }^{32}$ While Rawls argues that the distribution of basic goods in society must be provided, Gheaus argues that 'care', broadly construed, is subject to unequal distribution in society. Under the category of care, Gheaus includes: the care required to come into existence; to be sustained through food and physical care through childhood; care as an attitude that teaches self-care, for example, receiving good nurture during illness or encouragement in studies that lead the grown individual to provide good care for herself as an adult who has experienced such modelling of care; networks of care, such as social networks, like those who assist one's immediate family with job connections, or other forms of favouritism; and deeper social connections such as friendship or extended family. All of these forms of care significantly contribute to the development of character and to the ability to exercise virtue, and yet are subject to a great deal of moral luck, and not moral choice. Children do not choose their families of origin, the communities into which they are born, and whether they are strong or weak social networks. While some social institutions can help to mitigate bad moral luck, institutional care cannot replace personal, one-on-one care that stems from deep, personal relationships of family and friendship, so Gheaus suggests a certain degree of caution in thinking that institutional care can be a sufficient response to moral luck. Her conclusion is to state that egalitarian political theories can never adequately accommodate the ethics of care, that is, no political system can really prevent the contingencies of moral luck that affect care relationships.

Aristotle's strength is to acknowledge the significant role of such luck in ethical formation. Aristotle admits to a certain kind of weakness in those who are incontinent as a result of birth or as a result of how they are educated. Care or nurture $\left(\tau \rho \circ \phi \eta^{\prime}\right)$ can enhance or diminish the possibility of becoming a virtuous person, and yet, Aristotle is well aware that they are not equally distributed. Aristotle does not discount the possibility that some forms of human unhappiness are beyond our control, insofar as being born prone to incontinence, or being poorly raised by inadequate parents or inadequate laws, is partly a matter beyond individual choice. To this extent, Nussbaum is right to identify in Aristotle a sensitivity to the tragic

\footnotetext{
32 Anca Gheaus, 'The Challenge of Care to Idealizing Theories of Distributive Justice', in Lisa Tessman (ed.), Feminist Ethics and Social and Political Philosophy: Theorizing the Non-Ideal (Springer), 105-19.
} 
element in human life; this tragic element exists not only for those who are like Priam (virtuous, but then hit hard by loss), but also those who are unable through circumstance to get to Priam's level of virtue in the first place. Especially if we concede that care is fundamental to the development of virtue, and yet unequally distributed, Aristotle's theory is attentive to the role of chance in moral development.

Despite this acknowledgement of unequal beginnings, Aristotle ultimately places most of the responsibility for particular moral choices on the individual. Even in the case of vice, a moral actor must make those choices that can reshape his own character in order to become more virtuous. Book III's explanation of the voluntary and involuntary begins with the basic claim that virtue and vice are in our power. Virtue and vice alike develop in our characters as a result of repeated, chosen actions. Habitually acting generously makes us generous; habitually acting courageously makes us courageous. While it might be possible for a person to choose to live poorly so often that eventually he lacks the freedom to choose otherwise, Aristotle still places the burden on the moral actor: like someone who has cast a stone away, and cannot now recover it, a moral actor acted in ways that once were in his own power, and so he is morally responsible for who he has become: 'The same is true of weakness or maiming; for everyone would pity, not reproach someone if he were blind by nature or because of a disease or a wound, but would censure him if his heavy drinking or some other form of intemperance made him blind' (N. Ethics 1114a).

However, the case of the person who was raised poorly raises certain difficulties. If Aristotle thinks that the incontinent person is incontinent and unable to control his impulses because of past education and upbringing, how do we expect him to act virtuously now? If those who lack good experiences of early care and nurture can act in ways that only increase vice as a result of early experiences, how do we get them to act in a more virtuous manner now? Put succinctly, if one needs virtue in order to act virtuously, then it seems problematic to ask that the person who lacks virtue as a result of moral luck take responsibility for his moral failure, if its possession is what is required for a proper response. There seems to be a problem of circularity: one would need virtue to act virtuously, and need to act virtuously, in order to be virtuous; yet, this is precisely what has been harmed through moral luck. 
Aristotle's strength is to recognize the ongoing reality of this paradox, and not to seek to escape it through theoretical machinations. Aristotle's understanding of the difficulty of moral education includes sensitivity to the ways in which human beings are mutually dependent upon one another for their moral care, as well as physical and emotional care. The circular connection between being virtuous in character, and acting virtuously out of that state, is not necessarily a vicious circle. We do not find in Aristotle a logical problem with the mutual dependence of virtuous action on character, but instead a practical one. In some cases of incontinence ( $\left.\alpha \kappa \rho \alpha \sigma^{\prime} \alpha\right)$, even the practical limitations might be overcome. While it is true that the generous person will find pleasure in generous acts, and these acts continually reinforce his generosity, it is also the case that a nongenerous person can choose to become more generous through repeated, deliberate practice of generosity. Even if now it is uncomfortable, eventually through repetition, he will find pleasure in it when he does become a generous person. Indeed, he might already find a certain kind of pleasure in the anticipation of becoming such a person. This is how we raise children to become generous, through small steps, where we reinforce the child's acts of sharing-for example, praising a young child with even the smallest act of sharing a toy with another. The same might be said in the case of an adult who experienced a lack of care, or a Philoctetes who feels damaged by a long abandonment: a certain degree of choice to perform the virtuous act over the non-virtuous act can be fostered and nourished over a longer period of time. Not only individuals like Neoptolemus, but also entire societies can take on the role of encouraging and supporting such choices in others.

The deeper difficulty arises with cases of vice, in which the moral actor not only cannot act virtuously, but even understands the bad to be good. In such cases, there will be no motivation to act in accordance with virtue, for the ends toward which the moral actor is oriented are mistaken. Here Aristotle argues that the law must take over where family and friends are unable to develop proper sensibilities about moral virtue, by at least punishing those who act without care for the good either of themselves or of society. However, the law and institutional support of such moral choice can never substitute for the individual responsibility to participate in the process of developing virtue. 
Political bonds between those who are neither intimate friends, nor merely formalized legal relationships, are also a necessary presence for the moral education of the citizens. Notably, Aristotle does not rely on the phrase $\pi о \lambda i \tau \iota \kappa \eta \phi \iota \lambda i a$, or 'civic friendship', in developing his Politics. ${ }^{33}$ Neither is concord primarily a bond based in virtue; instead, concord concerns shared interests of a utilitarian nature. ${ }^{34}$ His avoidance of $\phi i \lambda i^{\prime} \alpha$ as the grounding of political relationships rests in part on his recognition that the kind of care that takes place in an interpersonal relationship of $\phi \lambda^{\prime} i^{\prime} \alpha$ is qualitatively distinct from the care that legislators can offer to the citizens of the $\pi o^{\prime} \lambda_{\iota s}$. For Aristotle, $\phi \iota \lambda i \alpha$ provides a sort of intimacy of care that is generally lacking in institutionalized forms of care. Such a human need for $\phi i \lambda i i^{\prime} \alpha$ suggests that there are limitations to political systems, such as that in Plato's Republic, which seek to make the city and public life the primary source of care and 'brotherly love'. While the law's primary motivator is punishment, the motivation for friendship consists of genuine love of the other in a one-on-one relationship.

Nonetheless, the grounding of the community's bonds with one another exists as the result of social bonds that are analogous to friendship. Aristotle asserts that while the city initially comes into being for the sake of life, its ultimate purpose is for the sake of living well (Politics 1252b29-30). Civic relationships, as well as laws, are part of the means by which the city assists its members in flourishing, and not simply surviving. As opposed to contemporary rights based on liberal systems of government, Aristotle's political system requires a strongly experienced feeling of community. ${ }^{35}$ The bonds between citizens are not understood as respect for rights, equally given to all citizens. Instead, the political community is grounded in active participation in a variety of associations, both formal and informal. The bonds between various forms of association are variable in both intensity and intimacy, and do not always manifest equality between all citizens. Book VIII describes all political associations as aiming at a particular advantage for their members. Such associations simultaneously bind together their members, while also separating those who do not belong from the particular form of friendship and care engendered by such association. Inevitably, different groups of associations will cause conflicting loyalties, and can even threaten

33 Stern-Gillett, Aristotle's Philosophy of Friendship, 149.

34 Pangle, Friendship, $158 . \quad{ }_{35}$ Pangle, Friendship, 81. 
political cohesion if taken too far. Competition for honours, too, can cause division. ${ }^{36}$ However, precisely because Aristotle's $\pi{ }^{\prime} \lambda_{\iota s}$ is grounded in more intensely felt relationships and interdependencies than those found in formal legal bonds, it also deeply engenders an experience of belonging. Aristotle's description of concord, for example, includes the experience of genuine good will for others, beyond the simple utility that agreement brings for one's self interest. ${ }^{37}$ One cares not only for the common good in abstraction, but also for those whom one knows to be a part of the same political community, in their concreteness, as those who share similar opinions and goals. And while competition for honour can be factious, honour is interpersonal by nature. Honour binds together those who participate in merit-based competitions and in the giving and receiving of honour.

Political friendships and intimate friendships are distinct, but powerful, motivators for the moral development of human beings, because of the need that human beings have of one another, and the limits of any single form of relationship for all forms of moral and political growth. Aristotle keeps alive the tensions inherent in our interpersonal relationships: for example, between the desire for friends to care for one another, even in the midst of moral failure, and the importance of recognizing the other as other, even as sometimes beyond our ability to help. The community, too, must play a role in the care of those still growing in virtue, or who suffer in lacking it and the accompanying $\epsilon \dot{\delta} \delta \propto \mu \rho \nu{ }^{\prime} \alpha$ that virtue brings. Indeed, it is precisely at points where individual relations of friendship or family fail that the larger community must step in to assist its citizens. At the same time, law and the larger community can never replace such intimacies, as contingent, imperfect, or powerless as they can be. For Aristotle, to be human is to require the vulnerability of being in relationship with family and friends, imperfect though they may be.

36 Pangle, Friendship, 84-5.

37 Pangle, Friendship, 156-7.

This is an open access version of the publication distributed under the terms of the Creative Commons AttributionNonCommercial-NoDerivs licence (http://creativecommons.org/licenses/by-nc-nd/3.0/), which permits non-commercial reproduction and distribution of the work, in any medium, provided the original work is not altered or transformed in any way, and that the work is properly cited. For commercial re-use, please contact academic.permissions@oup.com 
This is an open access version of the publication distributed under the terms of the Creative Commons AttributionNonCommercial-NoDerivs licence (http://creativecommons.org/licenses/by-nc-nd/3.0/), which permits non-commercial reproduction and distribution of the work, in any medium, provided the original work is not altered or transformed in any way, and that the work is properly cited. For commercial re-use, please contact academic.permissions@oup.com 


\section{7 \\ Tragedy, Katharsis, and Community in Aristotle's Poetics}

In these past chapters, I have developed a concept of vulnerability and its importance to community. I have also argued that myth and narrative play an important role in allowing both individuals and a community to be responsive to vulnerability. To this point, my focus on narrative has been through how specific works of Homer, Sophocles, or Plato explore vulnerability, and how their narratives are important to achieving this end. Achilles, Philoctetes, Alcibiades, Oedipus, and others all struggle with both real and symbolic wounds and come to terms with such wounds, at least in part, through narrative. The authors themselves are also engaged in storytelling in ways that assist their own audiences in coming to terms with vulnerability. For example, Socrates' narration of the myth of judgement in the Gorgias is as much of value for the audience of the Platonic dialogue in their own grappling with questions of justice and the wounds suffered through injustice, as it is for Callicles. Aristotle adds further to this picture in his account of friendship and its vulnerabilities, as those who lose friendships to vice must themselves find ways to assimilate the loss through a kind of revised narrative about the friendship and its meaning.

Aristotle's Poetics further contributes to a deeper understanding of how narrative can assist in the proper response of the human person to vulnerability. In this chapter, I focus specifically on the question of the value of performed tragedy for the community of those who witness its performance, as a way of deepening this question about how and why narrative is helpful for responding to vulnerability. Not only the Poetics, but also the De Anima and the Rhetoric, make helpful contributions in understanding how narrative can help both 
individuals and the larger political community to be responsive to vulnerability. I first argue that the performance of tragedy has not only a personal, but also a political function in assisting a community to respond to the vulnerable in its midst. I then develop ways in which Aristotle's psychology is helpful for understanding how audiences might become more responsive to vulnerability through the witnessing of tragic performance. Last, I examine the concept of $\kappa \alpha \dot{\theta} \theta \alpha \rho \sigma \iota s$. $K \alpha \dot{\theta} \theta \rho \sigma \iota s$ need not be understood as the mere purgation of pity and fear, for Aristotle makes clear that both of those emotions have positive value. Instead, I argue that $\kappa \alpha \dot{\theta} \theta \alpha \rho \sigma \iota$ ought to be understood as a kind of 'rebalancing' of the individual and also the community. Careful reading of Aristotelian texts on $\kappa \alpha ́ \theta \alpha \rho \sigma \iota s$ suggests that he does not simply intend the mere purgation of feeling, but rather a deeper sense of rebalancing of the soul, as found in Greek medicinal theory. Tragedy can also assist the community in being more responsive to the vulnerable by enlarging its vision of 'what is'; tragedy enlarges the community's political reality and helps to reshape its responsiveness to suffering in its own midst. Two different strands of tragedy thus emerge as forces that attend to human vulnerability: the $\kappa \alpha \dot{\theta} \theta \rho \sigma \iota s$ of tragedy as a rebalancing of the community, and an accompanying epistemological reorientation of the community's self-understanding to include those who have previously been excluded from the field of vision.

In Chapter 1, I argued that Homer's narrative accounts of human mortality frame the lives of its characters in such a way that human life is given narrative shape and meaning precisely because of the finality of death. Only a temporal end provides for the possibility of a teleological account of life, since the end of a story significantly shapes its interpretation and meaning. In the Nicomachean Ethics, Aristotle takes up a similar puzzle about human happiness, namely, whether it is possible to call a person's life happy until that life has come to an end. Those whose lives end as did Priam's, with ruin of family and kingdom, cannot be said to be happy overall, despite genuine moments of well-being in their lives, and their unfortunate ends make their lives unhappy. Good or bad fortune can increase or 
decrease a person's blessedness (N. Ethics 1100b), but such events cannot be anticipated. Yet, it would seem strange to say that a man could only be happy after his death. Aristotle addresses this problem by suggesting that $\epsilon \dot{\delta} \delta a \iota \mu o v i a$ does not depend upon such fortune;

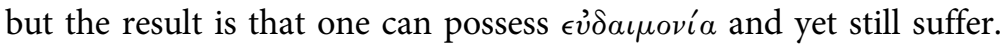
Thus, Aristotle remarks: 'And yet, even here what is fine shines through, whenever someone bears many severe misfortunes with good temper, not because he feels no distress, but because he is noble and magnanimous' (N. Ethics 1100b). ${ }^{1}$

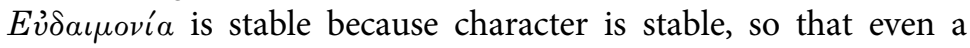
person who suffers greatly can be said to be 'happy', insofar as he will bear his suffering well. Suffering will not be decisive for his overall possession of happiness, though it will bring moments of pain (N. Ethics 1100b-1101a). In other words, the virtuous person who suffers well will himself incorporate his suffering into the larger picture of his life. He is not brought down by any one misfortune, because as a virtuous person he can better bear that misfortune than he would have otherwise. Character traits such as courage, temperance, generosity, and even wit can make such circumstances easier to bear, and since there is pleasure in their very exercise, the virtuous man can continue to experience some pleasure simply through being who he is. But for Aristotle, narrative can also play a role in bearing misfortune, especially through the witnessing of performed tragedy. Tragedy must contain $\pi \alpha \dot{\theta} \theta$ os, according to Aristotle: painful events that are beyond repair, or at least that leave a deep and unalterable change (1452b).

While contemporary students of Greek drama are often readers of texts, dramas were experienced as performances. Tragedy's location in the Dionysian theatre below the Acropolis placed it at the centre of Athenian life, not far from the áropá and the discourses of the council $\left(\beta o v \lambda \eta^{\prime}\right)$, as well as commercial and religious activity. ${ }^{2}$ As performative pieces, these works were not essentially verbal, but active. Even the most sophisticated verbal content in ancient drama was enacted such that the deliberative speech and practical embodiment of those

\footnotetext{
1 All translations of the Nicomachean Ethics in this chapter are from Aristotle, Nicomachean Ethics, trans. Terence Irwin (Cambridge, Mass.: Hackett, 1985).

2 Neal Croally, 'Tragedy's Teaching', in J. Gregory (ed.), A Companion to Greek Tragedy (Oxford: Blackwell, 2005), 60-1. Croally observes that the very language of placing events es meson, or 'at the centre', is significant for its links to the democratic.
} 
articulated ideas were not separable. ${ }^{3}$ Tragedy as performance expresses the link between the rational, imaginative, and active elements of human nature through unifying them before an audience that understands the performance to be a deliberate act of communication to them, in a specific and ritualized context. ${ }^{4}$ Tragedy was not performed for only one individual, much less for the reader of a text, but rather for a community in an overtly political context. The Dionysian festival was political in many of its non-dramatic events: for example, the presence of generals, the public display of tributes from other cities, awards given to those who had served the state, and the procession of orphans of war educated at state expense, all indicate the centrality of politics to the festival. ${ }^{5}$

The festival was also understood to be religious, in ways that overtly united the political and the sacramental. Martin writes of the procession of phalluses during the festival: 'In a typically Athenian melding, this too was political: in the fifth century BCE, each colony of the expanding empire sent a phallus for the procession. The announcement of honours to citizens and foreigners, the recognition of children of fallen warriors, the parading of subject states' monetary contributions-all made the festival into civic theatre, a spectacle of optimism and celebration counter-balanced by the darker tragedies on view. ${ }^{6}$ Even within the performance of a particular tragedy, an audience may have experienced the enactment of specific religious rituals. Sourvinou-Inwood, for example, has suggested that the ritualized elements of the end of the Eumenides were experienced as the performance of religious ritual in the present, and not only as a story at a distance. ${ }^{7}$ While during the ordinary course of the year, the wooden statue representing Dionysius was kept safely outside the city's limits, during the Dionysia it was processed to the Theatre of Dionysius. The religious devotion to Dionysius granted the audience the possibility of exploring elements of human experience, both personal and political, that at other times might be outside the normal

\footnotetext{
${ }^{3}$ Richard Martin, 'Ancient Theatre and Performance Culture', in Maryanne McDonald and Michael Walton (eds.), The Cambridge Companion to Greek and Roman Theatre (Cambridge: Cambridge University Press, 2009), 36.

4 Martin, 'Ancient Theatre', 38.

5 Croally, 'Tragedy's Teaching', 62.

6 Martin, 'Ancient Theatre', 49.

7 Christiane Sourvinou-Inwood, 'Tragedy and Anthropology', in Gregory (ed.), Companion to Greek Tragedy, 297-8.
} 
boundaries of propriety. In comedy, politicians were mocked, and political questions such as the justice of the enslavement of other Greeks undertaken. In addition, the emotional experiences of laughing, weeping, or even being shocked by dramatic events took place in a context that was socially and divinely sanctioned. Thus, while the sort of analysis that we have undertaken in the previous chapters is a valuable practice for us as contemporary commentators, the classical Athenian's experience of tragedy would have been more immediate, visceral, and closely connected to religious, social, and overtly political considerations.

According to Aristotle, tragedy's aim is to arouse pity $\left(\epsilon^{\prime} \lambda \epsilon O S\right)$ and fear ( $\phi o ́ \beta o s)$ (1452b). It is thus a form of $\lambda o ́$ 'os overtly concerned with the arousal of feeling in the audience. Pity and fear are made possible through $\mu i \mu \eta \sigma \iota s$, imitation of 'what is'; members of an audience can experience such powerful emotions only because the play imitates what is 'possible'. Aristotle somewhat cryptically states that one of the features of a good character in tragedy is 'likeness' (1454a). While he does not specify what he has in mind, I suggest that Aristotle may refer in part to a likeness between the character and the audience, sufficient for the audience to have the proper experience of the drama. In other words, tragic heroes are those for whom we can feel pity or fear, because we know that, to some extent or another, we are like them.

Aristotle's thoughts in the Rhetoric further illuminate the idea of 'likeness' of the tragic hero in the Poetics. There, we find insights into the psychology of exactly how dó yos can produce fear and pity in an audience. The Poetics states that recognition and reversal together cause the audience to experience fear or pity, in the case of tragedy, and which one is experienced is likely to depend on whether the audience member can imagine herself to experience the same kind of reversal. In his Rhetoric, Aristotle defines fear as a pain or disturbance due to a mental picture of some destructive or painful evil in the future (1382b). We are much more likely to see a particular event as fearful under certain conditions: if the outcome is imminent, i.e. sooner, rather than later; when those who can cause the harm are more powerful than we are; when we have already experienced a particular type of harm; and in the case of events that we cannot easily control. However, if these experiences are thought of as more likely to happen to others than to ourselves, then we might experience pity instead of fear (1382b). So, whether we feel fear or pity if we see a man 
such as Oedipus move from honour to exile in an unexpected reversal of fortune will depend very much on our own experiences of being vulnerable. For example, if an audience member has personally felt the threat of exile and is reminded that he could experience it again, he might be more likely to feel fearful; if he finds it quite difficult or impossible to believe that this sort of an event could occur to him, he might instead feel pity for the character.

Of course, both emotions might coexist in a single individual: I could simultaneously pity another for his suffering and also fear for myself. Still, the close connection between the two senses of $\phi$ ó $\beta$ os as a 'flight' and as 'fear' reveal something significant about how fear affects us. In an experience of fear for myself, my focus is on escaping or eluding the fearful object, or even a suffering person who reminds me of my own fears. Pity might draw me nearer to suffering, or at least minimize my desire to flee from it, out of a sense of connection to the other's need. In either case, Aristotle's suggestion is that the sorts of emotions that predominate in us depend very much on our sensibility of our own vulnerability to harm, and our experiential sense of closeness to or distance from those who suffer harm.

Aristotle's pairing of pity and fear in both the Rhetoric and the Poetics is significant. Their connection in the Rhetoric suggests that in Aristotle's view of tragedy, the two experiences are closely related for an audience and may coexist together, yet are important to keep conceptually distinct for the sake of differentiating between subtleties within a larger audience's experiences. If our own present belief as to the likelihood of experiencing harm informs whether we experience fear or pity, then it is likely that with any given audience, different individual members may experience a greater predominance of fear or pity. For example, a young male citizen who has little first-hand experience in war may be more likely to experience pity in response to the pleadings of the mothers in Euripides' Suppliants, especially if he identifies with Theseus' on-stage verbalization of such pity. However, a woman or foreign metic who has a different set of experiences concerning the treatment of non-citizens might have a response closer to fear, if he or she can identify closely enough with the powerlessness of the women. She may recollect prior experiences that indicate to her reliance upon others for the safe return of bodies after battle and proper treatment of the dead abroad; or her prior experience might intensify her pity in such a way that it becomes close to the experience of sympathy. While the question as to whether 
women, slaves, or children were present at the festival is a quite controversial one, there is some evidence that the festival was inclusive. ${ }^{8}$ At minimum, it was not restricted to male citizens. Resident metics who lacked citizenship, and foreigners to Athens, were certainly present among those in the audience. One fourth-century comedy title, 'Women Celebrating the Dionysia', implies some female participation in the Dionysian festival. Plato's Symposium suggests an audience size of as many as 30,000 individuals, though later analyses have suggested that the theatre held only 14,000 to $17,000 .{ }^{9}$ Any audience of such a size and variety is likely to have a wide range of backgrounds, and of emotional experiences of the play. As will become clearer below, this diversity of feelings is key for producing a diversity of opinions in discussions of a play, and so also for assisting in the development of rational deliberation of social and political matters. Indeed, the possibility of a rebalancing of the $\pi$ ó $\lambda_{\iota s}$ to accommodate points of view that have not been previously accommodated depends upon the ability of tragedy to introduce and to bring to awareness such standpoints to a range of members in its audience.

Aristotle asserts that tragedy, by its nature, requires the presence of $\pi \alpha \theta_{o s}$, that is, the undergoing of suffering of significant magnitude and lasting effect. Among the central features of audience experience, then, is to confront vulnerability in the characters and events being performed before them. ${ }^{10}$ Such vulnerability may include larger, abstract truths about mortality or sudden reversals of fortune that lead an individual to think of himself and his own vulnerability to suffering. A variety of particular feelings arise in relation to such suffering aside from fear and pity, however. Careful analysis of these accompanying feelings helps to illuminate how tragedy functions to elicit the deepening of care and concern for the vulnerable.

${ }^{8}$ For details in the controversy, see Croally, 'Tragedy's Teaching', 62-3; E. Csapo and W. Slater, The Context of Ancient Drama (Ann Arbor: University of Michigan Press, 1995), 286-93; and Jeffrey Henderson, 'Women and the Athenian Dramatic Festivals', Transactions of the American Philological Association 121 (1991), 133-47.

9 A. W. Pickard-Cambridge, The Dramatic Festivals of Athens, 2nd edn. (Oxford: Oxford University Press, 1988), 236; Croally, 'Tragedy's Teaching', 62-3.

${ }^{10}$ See Ruth Scodel, 'Sophoclean Tragedy', in Gregory (ed.), Companion to Greek Tragedy, 233-49. Scodel notes that Sophocles, in particular among the tragedians, communicates the importance of compassion for those who suffer. 
Ironically, since imitation is pleasurable not only to perform, but also to witness, even seeing a terrible scene of suffering in a play has a kind of pleasantness to it. A tragedy's 'scene of suffering'-'a destructive or painful action, such as death on the stage, bodily agony, wounds, and the like' (Poetics, 1452b) - is pleasant to behold, Aristotle states, even as it makes us feel some unpleasant emotions at the same time. ${ }^{11}$ (Thus, today we may experience the appeal of a movie that scares us, or makes us cry.) Since suffering is unpleasant to experience and to witness in others, in ordinary life humans tend to avoid its presence. Others have suggested that a person may even rationalize its existence in order to exclude it from one's field of vision. For example, Rousseau remarks on the human ability to reason ourselves away from natural sympathy:

Nothing but such general evils as threaten the whole community can disturb the tranquil sleep of the philosopher, or tear him from his bed. A murder may with impunity be committed under his window; he has only to put his hands to his ears and argue a little with himself, to prevent nature, which is shocked within him, from identifying itself with the unfortunate sufferer. ${ }^{12}$

Tragedy draws upon the pleasure of imitation in drawing us closer to, rather than further away from, suffering. In order to produce such pleasure, however, tragedy must strike a balance between sufficient likeness of its characters to us, and a certain degree of distance from our current circumstances. Tragedy must mediate our experience of suffering sufficiently to make its experience pleasurable. At some level, the audience must always remain aware of the artifice of the play. Such distance is necessary for a tragedy to have success; at least, known instances of tragedies that directly referred to recent events seem to have been poorly received by Athenian audiences. For example, in 493/2 BCE Phrynichus was fined 1,000 drachmas for his Capture of Miletus, due to its directness about the difficult title event only two years before. ${ }^{13}$ Direct discussion of recent political events or social upheaval risks alienating one's audience, who may find the emotions aroused to be overwhelming or may find their intellectual

11 Translations of the Poetics are from Aristotle, Poetics, trans. S. H. Bucher (London: MacMillan, 1895), accessed online at the MIT Internet Classics Archive $<$ http://www.classics.mit.edu/Aristotle/poetics.html>, 2010-11.

${ }_{12}$ Jean-Jacques Rousseau, Discourse on the Origin of Inequality (Cambridge, Mass.: Hackett, 1992), 49.

${ }^{13}$ Herodotus 6. 21. See Croally, 'Tragedy's Teaching', 67. 
and moral commitments too deeply rooted to be comfortably affected.

Tragedy must also strike a balance in presenting a hero who is neither too good nor too deeply flawed. Aristotle's claim that reversal ought to arise neither from a man's villainy nor from a man of complete and perfect virtue is sensible, for most persons are unlikely to identify with either extreme. Regardless of the accuracy of our selfassessments, none of us imagines ourselves to be either complete villains or paradigms of perfection. However, an audience member can easily imagine himself to be 'good, but not perfect', and so identify with the downfall of another person who is like us, or a little better or worse than us in particular respects. Thus, Oedipus as king may strike us as both cleverer than us in solving the riddle of the Sphinx, and yet maddeningly blind in his inability to see his own role in his downfall.

The enactment of episodes of suffering is itself a way in which an audience can identify with vulnerability, for Aristotle sees the imagination as a faculty that exists for the purpose of helping us to flourish through assisting our practical reasoning. The imagination suggests different possibilities to us from our present circumstances and suggests alternatives to practical reasoning. ${ }^{14}$ Below, I will offer a more detailed textual analysis of the role of the imagination, but for the moment, an intuitive example of the relation between imagination and practical reasoning may suffice. If we witness a scene of suffering that is seemingly unavoidable, such a scene triggers our own natural disposition to escape suffering and to find ways to act, so that we might be happy again. When a character on stage is deprived of such means, and an audience is made to imagine that he cannot and will not possess such means to escape, then we even more strongly identify with the character's suffering by virtue of being practical reasoners, like him. Our own practical reasoning is, in a sense, frustrated. Were his suffering real, our own sympathetic response might be intolerable; we might just not want to see it any more. But resting assured that such a scene is 'only' imaginary also allows an audience member to engage more deeply with such suffering, precisely because the scene is not real.

\footnotetext{
14 See Christopher Long, Aristotle on the Nature of Truth (Cambridge: Cambridge University Press, 2010), 86-96.
} 
Tragedy thus brings together our desire for happiness as imaginative, practical reasoners and an imagined reality in which another's existence is denied the same kind of happiness that all human beings desire. We thus are made more deeply aware of our own frailty and the possibility that the happiness that we desire, imagine, and act to attain might not always be achieved. Further, through seeing this limit exhibited by another whose circumstances draw upon our own feelings and imagination, there is also political value in each person becoming more aware of the vulnerability of others.

Effective plays often feature characters who are sufficiently unlike many audience members, such that they enact $\sigma v \mu \pi \alpha \dot{\theta} \theta \epsilon \alpha$ in its most literal sense, that is, a shared $\pi \alpha \dot{\theta} \theta$ os with someone whose actual condition is distinct from my own. As discussed in an earlier chapter, $\sigma v \mu \pi \alpha \dot{\alpha} \theta \iota \alpha$ can only take place when the 'other' with whom I share feeling is not in an identical situation to my own (the latter being commiseration). Yet, he must be sufficiently similar to me that I could see myself in his position. For example, an audience member who feels distress at Oedipus' self-blinding partly shares in that character's suffering, though not in a way that is identical to the physical pain or the intensity of the emotional suffering of the character. He may dread blindness or self-harm, even if he does not see himself as one who could pollute through incest or parricide. Even here, Sophocles may connect a spectator to Oedipus in ways that are unexpected. Consider an audience member of Oedipus Rex who strongly identifies with Oedipus' own sense that he 'could not' be a person who would murder his father or commit incest, and yet knows the myth's truth that Oedipus is indeed such a man. That spectator will probably experience some cognitive dissonance between his identification with Oedipus's denial, and the knowledge that Oedipus is the offender. It is precisely in the dissonance between these two sets of feelings and thoughts, i.e. both through identification with the character and separation from him, that a movement toward greater sympathy, even for the polluter, can take place. Someone who experiences such dissonance may ask herself, for example, if Oedipus thought he could not be one who unknowingly creates pollution, how can I be certain that I could not also do so?

Significantly, this $\pi \dot{\alpha} \theta$ os for suffering is a shared $\pi \dot{\alpha} \theta$ os with others, and in two directions: what I will call the 'vertical' and 'horizontal' dimensions. First, when an audience member shares at least partly in the feelings of a character (as when Neoptolemus takes pity on 
Philoctetes), we find a 'vertical' connection between character and audience, one that is asymmetrical. (A spectator feels along with a character but not vice versa.) Second, there is an additional set of shared feelings between audience members who are simultaneously experiencing the performance of a tragedy together. Witnessing a play as part of a community includes this 'horizontal' dimension of $\sigma v \mu \pi \alpha \dot{\theta} \theta \iota \iota \alpha$ across social and political boundaries that otherwise exist in the community. Shared feelings and experiences, brought on through the experience of strong feeling in response to art, serve as unifiers of the community. At times, the connections between lived experience and tragic events might be striking. Knox notes that in the light of the fragility of the political situation at the time of the performance of Oedipus Rex, and its recent experience of the plague, 'The audience which watched Oedipus in the theater of Dionysus was watching itself. ${ }^{\prime 15}$ Such shared feelings may unite and more closely connect those within the community who are reminded of shared experiences in times of suffering, such as war or plague.

Tragedy also may include a wide range of characters that expand the sense of who constitutes the community, through its own inclusion of slaves, women, children, foreigners, and those defeated in war among its characters. As Hall has argued, members of groups that were excluded from overt political participation on the basis of gender, ethnicity, or status were included among the voices of characters in tragedy. ${ }^{16}$ Croally suggests that tragedy then serves the function of questioning the ideology of the society, where ideology is understood to mean 'the authorized self-definition of the dominant group, that is, the citizen body. ${ }^{17}$ Watching Euripides' Trojan Women, a play that raises serious questions about the legitimacy of enslavement, would be a particularly intense experience if a slave were watching the tragedy along with his master. In such cases, spectators may not only be engaged with their own responses to the staged events, but also with how others in the community are responding to them. A spectator's $\sigma v \mu \pi \alpha \dot{\theta} \theta \iota \alpha$, in such cases, would be not only for the enslaved women on stage, but also even for his own

\footnotetext{
${ }^{15}$ Bernard Knox, Oedipus at Thebes: Sophocles' Tragic Hero and his Time (New Haven: Yale University Press, 1957), 77.

${ }^{16}$ Edith Hall, Greek Tragedy and the British Theatre 1660-1914 (Oxford: Oxford University Press, 2005), 123.

17 Croally, 'Tragedy's Teaching', 67.
} 
slave. Even if slaves were not present in the audience, the articulations and thoughts and feelings on stage may sympathetically expand a citizen's understanding of his slave's own experience.

We see then the possibility of theatrical experience as a way of mediating social and political relationships through its production of $\sigma v \mu \pi \alpha \dot{\theta} \theta \iota \alpha$ and dissonance, especially to the extent that Athenian theatre was a gathering of many in the larger community, across social differences. Spectators may also wonder about differences in others' responses to a tragedy. For example, if a spectator finds herself unexpectedly feeling anger along with Medea against Jason, despite her horrific crimes, she may wonder whether others similarly experience such sympathy for Medea. Or she may feel incapable of such sympathy, and wonder at its existence in others. If we bring together both these directions of $\sigma v \mu \pi \alpha \dot{\alpha} \theta \iota \alpha$-between character and spectator, and across audience members-we find that the dissonances between audience members, as much as the shared feelings, are necessary to encourage moral and political questioning. ${ }^{18}$ For, on an Aristotelian account, moral feeling, imagination, and practical reasoning are intimately linked. Tragedy draws upon reason as well as feeling, and these two faculties are integrated through the exercise of the imagination.

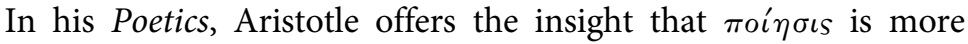
philosophical than history, for the poet can deal with the general and the necessary, while the historical concerns the particular and contingent (Poetics 1451b). That is, the historian is bound by the facts of the matter; if a particular historical figure was motivated to begin or end a war for a particular reason, the historian must be accountable to that fact. Пoi $\eta \sigma \iota s$, however, has fewer limits. The poet can invent a character, his motivations, and the events that surround him, in order to point to whatever more general and universal claim he wishes to make, and show what is 'possible' and 'necessary' (1451b). Aristotle does not seem to have in mind realistic plots. Nowhere does he criticize a play for being too fantastical in its machinations of plot (for example, asking whether Philoctetes could survive on an abandoned island for ten years, whether Herakles could appear from heaven, or whether the curse on the house of Thebes could take just

${ }^{18}$ On this point, see also A. M. Bowie, 'Pity, Fear and Citizenship: The Politics of Aristotle's Poetics', in Derek Barker (ed.), Tragedy and Citizenship: Conflict, Reconciliation, and Democracy from Haemon to Hegel (New York: SUNY Press, 2008), $56-9$. 
as it did). Rather, when Aristotle discusses the 'necessity' of tragedy, he focuses on the actions of the character with respect to his or her tragic choices. The poet can express 'what such and such a kind of man will probably or necessarily say or do' (1451b).

For example, although Oedipus Rex has an improbable element, the logic of its characters and their actions remains intact; the lack of logic is 'outside of the tragedy' (1454b). Tragic characters must be good; fitting to the types of persons they are; 'like the reality'; and consistent (1454a). Although Aristotle is often said to prioritize action $(\pi \rho \hat{\alpha} \xi \iota s)$ over character, and so to be less 'psychological' than many more recent playwrights, ${ }^{19}$ he does state the importance of a proper approach to character in tragedy. The play must have an internal logic to its action, and that logic is character driven. The characters must choose and act in ways that seem naturally to arise from who they are, both in general (male, female, noble, or slave) and in particular ways: for example, Antigone in her passionate devotion to family, Oedipus in the wisdom he accords himself, and so on.

Tragedy engages our ethical judgement about more universal questions, since an audience member must consider whether the suffering of its characters is justly deserved or not, often in the light of circumstances in which the character is subject to significant and conflicting pressures. For example, Antigone's and Creon's conflicts between family and $\pi$ ó $\lambda_{\iota s}$, or Orestes' conflicting obligations to his dead father, mother, and the gods, engage our own questions about vulnerability to suffering in the light of conflicting sets of moral and religious obligations. A character such as Orestes who takes up the decision to enact revenge may stand in contrast with the lived experiences of the fifth-century Athenian world, which would require the law, and not vengeance, as a proper response. However, as Cairns has argued, such a narrative still provides ample room for exploring whether Athens's own system of justice adequately addresses the difficulty of normal human feelings of desire for revenge after harm. ${ }^{20}$ Or one may wonder how to respond adequately to the experiences of others whose families have been victimized in the context of a system that removes a degree of subjective preference from the enactment of justice.

19 See, for example, Martin, 'Ancient Theatre', 36-54.

${ }^{20}$ Douglas Cairns, 'Values', in Gregory (ed.), Companion to Greek Tragedy, 305-20. 
The invented narratives of tragedy may also sharpen insights into issues of more immediate and specific political relevance. Bowie has suggested strong parallels between the question of Philoctetes' return in the Philoctetes and the question as to the justice of Alcibiades' return to Athens shortly before the 409 вСе production. He connects Alcibiades' desecration of the hermai and the question as to whether he could safely return to Athens to Philoctetes' exclusion from the political community as a result of his own desecration of sacred ground. ${ }^{21}$ In response, Debnar importantly notes that there is not a single one-to-one analogy between the characters of the Philoctetes and political figures. Odysseus also shares certain traits with Alcibiades, as much as does Philoctetes-such as the desire to use language for the sake of power. ${ }^{22}$ Nonetheless, the play's deep engagement with issues surrounding the justice of rhetorical manoeuvring, the return of men who have desecrated sacred territory, and the proper response, are all significant to the community's coming to be more capable of debating the justice of Alcibiades' participation in the community, or the future treatment of like cases. Or, to return to the example of the Suppliants, Bowie has argued that the refusal of the Thebans to return the bodies of the dead would have recollected the bitter defeat against the Boetians at the Battle of Delium only a couple of years before the play was produced. ${ }^{23}$ Were the viewing of tragedy to be followed by discussion of its content among those who had viewed it, such an experience provides the groundwork for additional broadening of understanding human experience through engagements with others about the topic of the tragedy. Tragic theatre thus can become a part of the process of learning how to debate and act in a democracy, through the debates that can arise from viewing and responding to drama as a community. ${ }^{24}$

${ }^{21}$ A. M. Bowie, 'Tragic Filters for History: Euripides' Supplices and Sophocles' Philoctetes', in B. R. Pelling (ed.), Greek Tragedy and the Historian (Oxford: Oxford University Press, 1997), 56-8.

22 See Paula Debnar, 'Fifth Century Athenian History and Tragedy', in Gregory (ed.), Companion to Greek Tragedy, 18-20. Bowie himself also makes the connection between Odysseus and Alcibiades. See Bowie, 'Tragic Filters for History', 58-9.

${ }^{23}$ Bowie, 'Tragic Filters for History', 45-56.

24 Paul Cartledge, 'Deep Plays: Theatre as Process in Athenian Civic Life', in P. E. Easterling (ed.), The Cambridge Companion to Greek Tragedy (Cambridge: Cambridge University Press, 1997), 3-35. 
Tragedy gives licence to a community to explore difficult issues in a mediated way through moving its audience back and forth between experiences of closeness to and distance from the experiences of the characters and events of the tragedy. Sourvinou-Inwood has identified those devices that bring the world of the play closer to that of classical Athens as 'zooming devices' and those that separate the two worlds as 'distancing devices'. ${ }^{25}$ For example, in the Antigone, Creon's assertion to Haemon that his son has a duty to obey his father strongly echoes the ephebic oath that all youth swore at the age of 18 , to obey the laws of the state and be pious. ${ }^{26}$ Such verbal echoes suddenly move the social and political field of the play significantly closer to the audience. Fantastical elements, such as the machinations involved in Oedipus' birth, abandonment, adoptions, and subsequent move to Thebes that lead to his incest, distance the audience from the play.

Such distancing is necessary for the fullness of an audience's engagement with a tragedy. First, the audience depends upon the idea that the scene before him or her is a performance if he or she is to engage more deeply with the difficult emotional upheaval of witnessing suffering. Paradoxically, knowing that the actor playing Oedipus on stage is not blind at his own hand, but rather wears a mask that signifies his blindness, allows the spectator to look more closely. The distance afforded to the spectator by the knowledge that the play is 'only a play' provides the space for entering into the experience and remaining with it. Aulus Gellius tells the story about Polus' use of his own son's ashes in a play as a prop in a fourth-century tragedy. ${ }^{27}$ His objection that it was not truly a performance, but actual grief, is not simply that of a critic evaluating good or bad acting. Rather, he implies that the actor has violated audience expectations about artifice. The boundaries provided by the play's removal from the reality

${ }^{25}$ Christiane Sourvinou-Inwood, 'Tragedy and Anthropology', in Gregory (ed.), Companion to Greek Tragedy, 297-8. See also C. Sourvinou-Inwood, 'Assumptions and the Creation of Meaning: Reading Sophocles' Antigone', Journal of Hellenic Studies 109 (1989), 134-48.

${ }^{26}$ Sourvinou-Inwood, 'Assumptions', 144.

27 See Attic Nights 6. 5-7. 8, trans. J. C. Rolfe (Cambridge, Mass.: Loeb, 1927) and Ismene Lada-Richards, 'Greek Tragedy and Western Perceptions of Acting', in Gregory (ed.), Companion to Greek Tragedy, 400. As Lada-Richards explains, contemporary actors, especially method actors, might have a quite different view of how characters are mediated through the 'self' that each actor brings to bear on a role. 
of the actors' lives and even the audience's particular experiences provide a safe space for the encounter of difficult issues. At minimum, the audience need not worry about the actor behind the mask, for his wearing of the mask makes clear at every moment that this is a performance for him. Spectators can more fully spectate, that is, observe, free of the obligation to act in response to another's sorrow. The freedom from action is also a way of deepening his or her focus in observing, imagining, feeling, and thinking about the play.

The vulnerability of specific groups within one's own $\pi$ ó $_{\iota s}$ may be among such sensitive issues that require this mixture of involvement and detachment in order to more fully 'see'. Athens, more than any other city-state, prided itself on its democratic procedures, breadth of culture, courage, and fortitude, as the tradition of funeral orations makes clear. The acknowledgement of social or political shortcomings is more difficult; Socrates attributes his being put to death in part to the anger of those who had been subject to his questions and shown up in their ignorance (Apology 23c-24a). Tragedy gives voice to those who are otherwise voiceless, for example, women and slaves, although it often does so while also reinforcing at least some of the authoritative structures that women, slaves, or metics found objectionable. ${ }^{28}$ Nonetheless, many tragedies seek seriously to articulate the concerns of those who would be considered 'outsiders' to Athenian citizenship, those whom Zeitlin calls 'marginal figures'. ${ }^{29}$ Tragedy includes among its characters women, foreigners, slaves, bastards, metics, children, and others who lack citizenship. These characters are marginal, insofar as they are not understood by their own culture to exist at the centre of human community, especially in the exercise of its political power. Zeitlin argues that marginal figures serve the purpose of the Other by which the Self is defined, as those at the centre of social and political power come to understand themselves better

${ }^{28}$ For example, Antigone's rebellion against male structures of power is also done for the sake of her brother, for whom she is willing to sacrifice her own life so that she might join him in the same grave.

${ }^{29}$ See F. I. Zeitlin, Playing the Other: Gender and Society in Classical Greek Literature (Chicago: University of Chicago Press, 1996) and Mary Ebbott, 'Marginal Figures', in Gregory (ed.), Companion to Greek Tragedy, 366-76. For reflections on the role of women's voices in tragedy, see especially H. P. Foley, 'The Conception of Women in Athenian Drama', in H. P. Foley (ed.), Reflections of Women in Antiquity (New York: Gordon and Breach, 1981), 127-68; and B. Seidensticker, 'Women on the Tragic Stage', in B. Goff (ed.), History, Tragedy, Theory: Dialogues on Athenian Drama (Austin, Tex.: University of Texas Press, 1995), 151-73. 
through understanding those who are at the margins of their society. Such self-knowledge and self-definition occurs in complex ways. Boundaries may be crossed between Self and Other. As Ebbott later phrases it, 'The Self is explored through the Other, but is not subsumed by the Other. ${ }^{30}$

In the chapters above, we find a number of marginal figures. Some, like Antigone or Ismene, are excluded from political power through lacking the status of being a male citizen. However, many marginal figures are not women, children, or slaves, and yet they occupy a marginal space. In nearly all of the examples provided in the previous chapters in this book, men who might otherwise be at the centre of social power experience living at the margins. Philoctetes is literally a liminal figure that is excluded from society, yet uses fire, a bow, and eventually dó os to maintain a connection to the community even in his isolation. Neoptolemus develops his sense of Self as a noble ( $\gamma \in \nu \nu a \hat{\imath} o s)$ person in part through his encounter with this Other, and through fear of becoming an Other himself if he does not obey Odysseus. The character of Philoctetes is one of a noble-born male citizen. As such, his presence as a marginal figure in the context of the play connects marginalization to those who normally possess power and a degree of security in their power. Similarly, Oedipus' fall from kingship to being the 'polluted one' moves him from the centre, even the pinnacle of the centre, to the margins. Even Socrates' myth of judgement implicitly takes the figure of Callicles and suggests that the power he seeks as a politician will be lost with the final judgement of his soul. Alcibiades breaks into the party of the Symposium and its order and reveals how he is at once in love with and disturbed by Socrates and his effect on his soul. Alcibiades is at the height of his own power, but shown to be brought down by his inability to live virtuously.

In each of these examples, tragedy or dialogue suggests that the Self is the Other, or potentially so. That is, these examples take persons who one would normally expect to be at the centre of society and expose them to circumstances (sometimes of their own choosing, but often not) that result in their becoming the Other. Through juxtaposing the experience of being Self and Other in a single character, tragedy invites its audience members to consider the same juxtaposition in themselves.

30 Ebbott, 'Marginal Figures', 366.

This is an open access version of the publication distributed under the terms of the Creative Commons AttributionNonCommercial-NoDerivs licence (http://creativecommons.org/licenses/by-nc-nd/3.0/), which permits non-commercial reproduction and distribution of the work, in any medium, provided the original work is not altered or transformed in any way, and that the work is properly cited. For commercial re-use, please contact academic.permissions@oup.com 
Free male citizens are asked to experience a degree of dissonance in themselves, insofar as they can identify with an individual who moves from the centre to the margins of society. Such an experience may make possible the recognition that those who are at the margins of real Athenian society are also Selves, and not only Others against which to develop one's own concerns. In other words, tragedy breaks apart the categories that normally separate Self and Other, those at the centre and those at the margins, and suggests that those who are at the centre of society have significantly more in common with those at its outskirts than they may have thought.

Of course, tragedy does not force an audience member to undergo such an intellectual transformation; neither does philosophical dialogue. However, both create the space for the creation of dissonance, pity, fear, and sympathy, which may lead to such intellectual considerations. Indeed, in tragedy, we find a strong link between the affective and the intellectual. Imagination is the key to linking these two dimensions of human experiences, for through its exercise, affect and practical reasoning are united.

Aristotle's account of the imagination and its link to judgement makes clear the importance of proper emotional responses in making good rational judgements. Nussbaum has helpfully argued that Aristotle's accounts of imagination ( $\left.\phi \alpha v \tau \alpha \sigma^{\prime} \alpha\right)$ and its relation to practical judgement ( $\phi \rho o ́ v \eta \sigma \iota s)$ and action in the De Anima Book III can help us better to understand his account of tragedy in the Poetics. ${ }^{31}$ In De Anima, Aristotle distinguishes between different faculties of the soul. The human being is both like and unlike animals. He shares with the animals the capacity for nutritive growth; locomotion; sensory perception; and a discriminating power that allows him to distinguish between sensory objects. At the same time, human beings are distinctive in their possession of speculative and practical thoughtalthough Aristotle also says that a small amount of the animal world also possesses practical thought $(427 \mathrm{~b})$. We also possess a

\footnotetext{
31 Nussbaum, Fragility, 264-89.
}

This is an open access version of the publication distributed under the terms of the Creative Commons AttributionNonCommercial-NoDerivs licence (http://creativecommons.org/licenses/by-nc-nd/3.0/), which permits non-commercial reproduction and distribution of the work, in any medium, provided the original work is not altered or transformed in any way, and that the work is properly cited. For commercial re-use, please contact academic.permissions@oup.com 
faculty of imagination, which depends on the possession of sensory faculties, but which is neither reducible to those faculties nor to discursive thought.

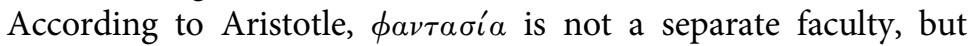
rather an activity that relies upon several faculties. ${ }^{32} \Phi_{\alpha \nu \tau \alpha \sigma^{\prime} \alpha} \alpha$ is closely related to sense perception. If one thinks of an apple and the apple is not present, one experiences sensation in the absence of the object; for example, 'seeing' red or imagining its crunch. The senses are 'sensing' in the absence of the object. The imagination presents the object to the subject as a $\phi a ́ v \tau \alpha \sigma \mu \alpha$, an image that in the absence of the object becomes an interpreter of a prior sense experience. To this extent, the imagination is also a rational and thinking faculty, in a way. As Brann describes $\phi a ́ v \tau \alpha \sigma \mu \alpha$, the image is not simply given by the imagination, but rather is a 'result that it achieves'. ${ }^{33}$ In other words, Aristotle's understanding of the imagination is an active faculty, one that participates in the production of our understanding of whatever is imagined. The imagination is not merely a passive faculty that re-presents a prior experience. Neither does it simply invent and give shape to a world that lacks its own structure. Instead,

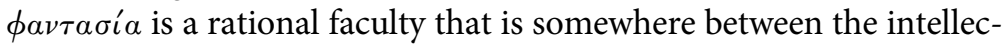
tual and the sensory.

Christopher Long notes the sense in which activity of its root, $\phi \alpha \nu \tau \alpha \dot{ } \zeta \epsilon \sigma \theta \alpha \iota$, must still be heard in ' $\phi \alpha \nu \tau \alpha \sigma i \alpha^{\prime}$ '. As he articulates it, 'the term itself comes to designate a power of the soul that occupies a kind of middle space-between expression and articulation, meaning and intention, and at a yet deeper level, between perceiving and thinking, object and subject, body and mind'. ${ }^{34}$ When tragedy (or philosophical dialogue, for that matter) invokes the imagination, it simultaneously draws upon our past, lived sensory experience and our rational capacity. Drama makes new connections between old experiences and our current reality, and opens up a new space in which the rational as well as sensory faculties of the person can be

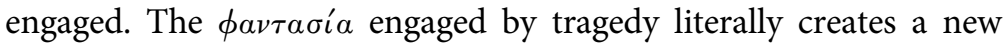
internal world in which not only sense experience, but also human rationality, can work on new material. Drama's engagement of our

\footnotetext{
${ }^{32}$ Eva Brann, The World of the Imagination: Sum and Substance (Lanham, Md.: Rowman and Littlefield, 1992), 40.

${ }^{33}$ Brann, The World of the Imagination, 43.

${ }^{34}$ Long, Nature of Truth, 83.
} 
imagination draws upon deeper recesses of our own experience and lived reality than can abstract argumentation alone.

Aristotle takes pains to emphasize that the imagination is dependent on animal sensory experience, and is a faculty shared with other creatures. According to De Anima III. 9, the imagination is an aspect of the animal soul that is necessary for animal motion. Aristotle's argument is that while animals are self-moving, we still must account for what within the animal 'makes' it move. Appetite and imagination, insofar as they lead to action, are inseparable. If I have an appetite for something, like a fresh apple to eat, already there is an end in mind. Aristotle says, 'appetite is in every form of it relative to an end: for that which is the object of appetite is the stimulant of mind practical; and that which is last in the process of thinking is the beginning of the action' (De Anima III. 10). ${ }^{35}$ In other words, one cannot say that an appetite is an appetite until it is an appetite for something. A general grumbling in one's stomach is not an appetite; a desire to eat an apple is. But this end, the apple, for it to be the 'stimulant of practical mind' and lead to action, must be imagined if it is to lead to action. One must think of an apple, imagine it, as that which might satisfy my hunger, at least in a general way. Conversely, Aristotle says, 'So, too, when imagination originates movement, it necessarily involves appetite' (433a). That is, if one is moved to do something by way of my imagination, there must be a desire that she wishes or hopes to fulfil. One might imagine something that one is not especially moved to seek to avoid; upon imagining a cloudy day upon reading the morning news, a person might do nothing about it. But where action is involved, animal appetite and imagination are closely linked.

For Aristotle, two kinds of imagination exist: perceptive and deliberative; while the latter belongs only to calculative animals, and the perceptive to any of those that possess senses, even worms and the like that have simple senses, deliberative imagination is also 'animal', by which Aristotle means that it exists as an outgrowth of the animated soul that seeks to achieve practical and moral ends. The presence of calculation is a difference as to the sorts of means that are used in considering ends and whether or how to pursue them, but both perceptive and deliberative imagination concern the well-being

35 The J. A. Smith translation is used throughout this chapter: Aristotle, De Anima, trans. J. A. Smith, in Aristotle, The Basic Works of Aristotle, ed. Richard McKeon (New York: Random House, 1941). 
of an animal, and are conducive to its end. Aristotle is insistent that nothing in nature exists in vain, and so all natural faculties of an animal exist (ultimately) for the sake of the animal's flourishing as the kind of being that it is. Imagination, too, is part of the natural wellbeing of living beings that possess it, and helps us to fulfil our needs.

Building upon this Aristotelian background, MacInytre in his Dependent Rational Animals argues that practical rationality is closely linked to our animal nature. ${ }^{36}$ While the tendency of much contemporary moral philosophy is to understand the human being in terms of autonomy, or self-rule, MacIntyre suggests that our reasoning as practical reasoners is linked to practical reasoning that is partly shared even with animals. Even those elements of human practical reasoning that exceed animal reasoning are grounded in preconditions for reasoning that are essentially animal. In other words, there is a whole range of conditions that make reasoning possible, and the extent to which different creatures satisfy these conditions exists across a graded spectrum across the animal world. Insofar as we are rational and social animals, we have social obligations to one another, based on our own need for care to become who we are, and our possibility of imagining ourselves into situations where we might need more care. That is, MacIntyre suggests that the vulnerability of the sick, disabled, child, or elderly, is not detachable from our moral status as practical reasoners or caregivers, but instead intricately intertwined with our humanity as such.

If we then return to the Poetics with this purpose in mind, we can see the mimetic arts function in part by drawing upon our animal natures as beings that by nature need others. Пoinoıs (broadly understood) is based on human need and lack. We imagine because we are the kinds of creatures that find ourselves in need of something, and when we have need, or even want, of something, we tend to imagine the object that we suppose might fulfil our desires. This is a kind of explanation for the claim earlier discussed in Plato's Symposium, namely, Diotima's suggestion that human creativity and giving birth takes place at the last stages on the ladder of love, when we are yet incomplete, but moving toward completeness. Aristotle also gives an account of creativity as activity that is born out of our being the kinds of creatures that lack.

\footnotetext{
36 Alasdair MacIntyre, Dependent Rational Animals: Why Human Beings Need the Virtues (Chicago: Open Court, 2001).
} 
Given the significance of imagination for action, it is not surprising that Aristotle locates the plot as more significant than character in tragedy: 'For tragedy is an imitation, not of men, but of an action and of life, and life consists in action, and its end is a mode of action, not a quality' (Poetics 1450a). If imagination is a key part of human action, then action on stage is one means by which we can effectively enter into the world of others. That is, since the chain of causation according to the account outlined above is the possession of an appetite, its fulfilment in imagination, and possibly also deliberation about how to achieve such ends and then action, then each of these points in drama becomes an entryway into the experiences of those different from us. We may not share their identical appetites, but can easily imagine our way into different courses of action that stem from the possession of such appetites, and so retrospectively understand why various sorts of people choose particular actions-even those that lead to suffering.

Human beings can imagine their way into others' realities, and so also gain a kind of understanding of their actions, appetites, and practical reasoning through imagination. Thus, in watching the Antigone, an audience member will do much more than note, intellectually, that Antigone is caught between a civic and a religious duty. She can understand Antigone's action of burying her brother and defying Creon because she can imagine the heroine's thoughts, feelings, appetites, and the origins of her movement in the play. Reading Hegel or Nussbaum's writings about Antigone and the philosophical conflict between civic and familial duty is an entirely different experience from watching Antigone and Creon argue on stage. The latter involves the engagement of one's emotions and even body, as well as one's intellectual faculties, for the exercise of imagination unites these faculties in us.

Of course, Aristotle carefully sets opinion apart from the imagination in De Anima: 'For imagining lies within our own power whenever we wish (e.g. we can call up a picture, as in the practice of mnemonics by the use of mental images), but in forming opinions we are not free: we cannot escape the alternative of falsehood or truth' (427b). Unlike in opinion, where we must choose to assent to or to dissent to a judgement (e.g. 'Alcibiades ought not have been asked to return to Athens'), in imagination, the mind can reign more freely. Imagination is neither subject to the limitations of sense perception nor to the limits of opinion: since in imagination the subject is not 
bound to the world as he has thus far known it, his capacity to think of things other than how they have been up until now significantly expands his vision of himself, other human beings, and the community. Tragedy draws upon both our sensory and our deliberative faculties, and so can move us in a way that is more in tune with the 'whole' of the human being than either abstract argumentation, or simple and direct encounters with the ordinary world, can.

Indeed, the imagination expands our sense of ontology, or 'what is'. In the Aristotelian view, we are the kinds of creatures that come to understand the world primarily (though not exclusively) through $\lambda$ ó yoı. Our understanding of being is always mediated through the words that we use to describe, categorize, and make sense of things. Yet, Aristotle offers a concept of language in which things themselves

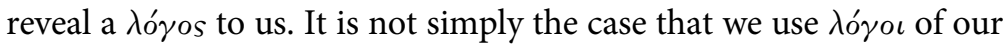
own invention to make sense of an otherwise unorganized or chaotic world. Nor do we superimpose our order on a different order. Instead, the structures of things themselves possess a hóros that allows things to reveal themselves to us and to be articulated in language. As Long phrases it, 'For Aristotle, each attempt to articulate something of the truth of things is already involved with the expression of the things encountered. ${ }^{37}$ Long's focus is on the whole of nature, including the non-human world; not only $\lambda$ óros-centred creatures, but all of being, shows and expresses itself to us, and in response, human beings seek to articulate its nature. However, the created world of the stage and its invented stories, performed with the use of $\sigma \kappa \eta \nu \eta^{\prime}$ and mask, also seeks to reveal and to articulate the nature of political realities that have not yet been realized. The enactment of what is 'possible', but which only exists in its particularity on the stage, also reveals the truth of realities.

Human beings are the sorts of creatures that come to know truth through $\lambda$ ó $^{\prime}$ or, and live in a world in which realities reveal themselves through $\lambda$ ó ou. However, the extent to which such things can and do reveal the whole of truth to us depends very much upon our experience and openness as enquirers. Drama, although a created and imagined world, can speak the truth to us precisely because it literally

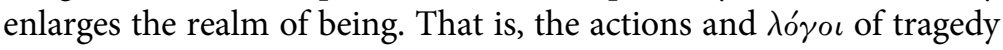
do not merely invent new concepts, or create new characters that exist

\footnotetext{
37 Long, Nature of Truth, 55. Of course, defending such a view is well beyond the scope of this paper, but Long offers a thorough argument.
} 
solely in a separable realm, apart from the 'real' social and political world. Instead, its $\lambda o ́$ yo $\iota$ and events reveal the nature of things, human things, through expanding the realm of what is 'possible'. To put it in the strongest terms, the world of the Dionysian theatre expands the being of the political world itself. New realities about Self and Other emerge, and these realities possess a political and social reality for the community that potentially changes its sense of its own identity. Such a reality, however, like ordinary reality, must still be interpreted. In order to be successful, a performance must resonate with some truth that is still seeking to be revealed; that is, a play that does not reveal anew something that 'is' will fail to have power over us. Additionally, an audience must interpret the actions, characters, and events of the theatrical world if that world is to emerge as an active part of the social and political world when the performance is left behind.

A tragedy that can articulate in word or in performance more generally a truth that we have so far not yet recognized, gives shape to the truth, because what it performs or asserts in some sense already existed. Thus, a character like Philoctetes has power over us because at some level, we are already familiar with the vulnerability of the marginalized and excluded, and already struggle with the question of who is inside or outside the realm of the social group that matters. Narrative reality is part and parcel of the social and political reality, because human beings are logo-centric and imaginative creatures that seek out 'the possible' by nature. But what constitutes a possibility that can move and affect us, even transform us, depends already upon our existent human reality. There is thus a productive tension between theatre and $\pi$ ó $_{\iota s}$, and between performance and $\lambda o^{\prime} \gamma o s$. These polarities are brought together in the exercise of the imagination.

\section{III}

Finally, we come to the difficult question of $\kappa \dot{\alpha} \theta \alpha \rho \sigma \iota s$, better equipped to describe its nature after examining the political nature of performance for the Attic world, and Aristotle's understanding of

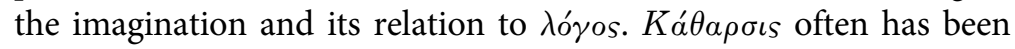
interpreted as the experience of an individual in which an excess of fear or pity builds up and must be released; at its most literal level the term means a 'purgation' or 'cleansing'. In $\kappa a ́ \theta \alpha \rho \sigma \iota s$, feelings are in 
some way purified or purged. However, Aristotle's ambiguous use of the term in the Poetics suggests at least three questions. First, are feelings of pity and fear purged and removed, or are they purified? Second, for what purpose ought such feelings undergo кá $\theta \alpha \rho \sigma \iota s ?$ Third, how does the performative nature of tragedy inform what might be intended by the idea of $\kappa a ́ \theta \alpha \rho \sigma \iota s ?$

While the concept remains controversial, a number of commentators favour a decidedly ethical approach as the aim of this release of feeling. Janko, for example, understands $\kappa a ́ \theta \alpha \rho \sigma \iota s$ as a form of 'moral purification', in which the emotions are aroused in such a way that after they subside again, they are 'retrained' to be less volatile. ${ }^{38}$ Such retraining results in the person's character being closer to the mean that constitutes virtue. By exercising fear and pity harmlessly, the individual is better prepared to return to living his ordinary life, as such emotions are less apt to control him. Janko's theory relies upon a particular understanding of medical $\kappa a ́ \theta \alpha \rho \sigma \iota s$ as 'homeopathic', in which a little experience of a problematic emotion allows one to release it so that the power of the emotion over the individual is lessened.

The difficulty with Janko's theory is that it does not fully take into account the positive value of experiencing pity and fear, not only in the mediated world of the theatre, but also in ordinary life. Although such emotions can be problematic in certain circumstances, Aristotle also takes seriously their value for living well. To return to Book II of Aristotle's Rhetoric for a moment, we find there that Aristotle does not only offer a psychology of how pity takes place, but in doing so, also connects its presence to justice and to friendship. A person feels pity if he feels pain at the sight of an evil that may befall either oneself, or a friend, when it is 'undeserved' (1385b). Among those more likely to feel pity are individuals with education and long experience of the world, as well as those who have living parents, children, or wives (1385b). Moreover, only those who believe in the goodness of at least some other people are capable of pity (1385b-1386a). This passage makes clear that pity is not a negative emotion (although it is painful). Indeed, its presence in those who are experienced, educated, and who believe in the possibility of undeserved suffering suggests that there is

38 Aristotle, Poetics I with the Tractatus Coislinianus, a Hypothetical Reconstruction of Poetics II, the Fragments of On Poets, Book I, translated with an introduction by Richard Janko (Cambridge, Mass.: Hackett, 1987), ix-xxiv. 
a connection for Aristotle between pity and justice. Since only those who believe that another's suffering is undeserved feel pity, then Aristotle implies that its presence in one who correctly understands and can identify justice is proper and good, when he is confronted with injustice. Similarly, the increased sensitivity of those who feel pity in cases where their close family members are alive suggests that $\phi \iota i^{\prime} \alpha$ and pity are also interrelated.

While Aristotle does not spell out the nature of this relationship in the Rhetoric, the Nicomachean Ethics might illuminate their relation. In friendship, a friend has genuine concern for the good of the other, even for the good of the other as 'another self', in the case of friendships of virtue (N. Ethics 1166a). So, too, do parents feel for their children as though the children are somewhat an extension of themselves, for their being comes from themselves (1161b), although they also take greater pleasure in loving their children than in being loved (1159a). Pity reflects the reality of a self that is deeply connected enough to others to feel the other's suffering as if it is their own, though at least sometimes in diminished intensity. Fear, too, is an appropriate response to certain threats, and indeed courage is not the absence of fear in every circumstance. Brave persons will not only fear those dangers that are frightening for anyone sensible, but 'even the sorts of things that are not irresistible' (1115b). However, 'he will stand firm against them, in the right way, as prescribed by reason, for the sake of what is fine, since this is the end aimed at by virtue' (1115b). Indeed, part of what constitutes the courageous person's ability to respond rationally and properly to danger is a proper kind of fear. Those who completely lack an appropriate emotional response of fear to genuine danger are not virtuous. They are so rare, because they are so far from the ordinary experience of being human, that Aristotle says, 'He would be some sort of madman, or incapable of feeling distress, if he feared nothing, neither earthquake nor waves, as they say about the Celts' (1115b). While his characterizations of Celtic people are rather fanciful, Aristotle's point is that total fearlessness is barbaric. To be human means to possess the proper amount of fear and pity, for both are necessary for proper care of the self and beloved others.

If pity and fear are important emotions in the life of virtue, then their simple purgation would be an insufficient motivation for experiencing tragedy; even if human beings are more prone to excess than deficiency in the case of fear, it is not at all clear that this is so in the 
case of pity. Indeed, their expulsion per se is not the aim of living well, but rather their proper incorporation into a life lived in just relationship with others. ${ }^{39}$ In the key passage in the Poetics, Aristotle's phrase

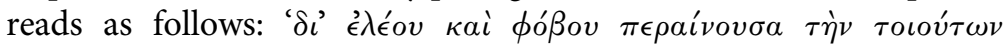

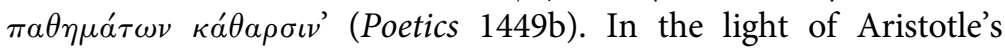
other remarks on the value of pity, fear, and related emotions, I suggest that we take Aristotle to mean by these lines 'through pity and fear it purifies emotions of this type'. That is, an interpretation that reads Aristotle as saying that the witnessing of tragedy removes what is problematic about emotions, rather than removing them altogether, is more consistent with his other remarks on the value of both fear and pity. The question then remains as to the nature and the purpose of such purification.

I suggest that we examine $\kappa a ́ \theta a \rho \sigma \iota s$ as a kind of 'purification' that removes impurities in the emotions of a community for the sake of a more balanced community that possesses greater self-knowledge and can accommodate ideas previously excluded or marginalized from its self-understanding. My argument proceeds in two fundamental steps.

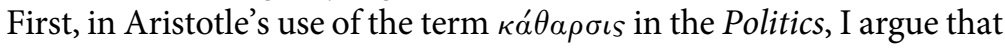
$\kappa \alpha ́ \theta \alpha \rho \sigma \iota s$ exists not as an end in itself, but as a means to restore balance and harmony to the whole of a musical piece. Such a reading of $\kappa \alpha \theta \theta \rho \sigma \iota s$ as a rebalancing is also consistent with the purpose of purgation and purification in Greek medicinal practice. Second, I argue that the purificatory activity of $\kappa a ́ \theta \alpha \rho \sigma \iota s$ in tragedy exists so that the members of a community may stand with a more balanced understanding of their own community and the appropriate way to feel and to understand its members. While much of the discussion of $\kappa \alpha ́ \theta \alpha \rho \sigma \iota s$ focuses on how individuals' emotions are affected, the performative nature of tragedy in the context of a political-religious festival ought to lead us to consider the effects of $\kappa a ́ \theta \alpha \rho \sigma \iota s$ on the community as a whole. Just as the $\kappa a ́ \theta \alpha \rho \sigma \iota s$ of medicine restores a wholeness and balance in the body, and the $\kappa \alpha \dot{\theta} \theta \rho \rho \iota s$ of music is a purification of the entire melody, the $\kappa \alpha \dot{\theta} \theta \alpha \rho \iota s$ of tragedy restores a kind of balance in the community. The balance is not simply one of being purged of the 'wrong' feelings, where fear and pity are in need of expulsion, but also of having the proper 'right' thoughts and feelings about the reality of one's

39 Bowie, 'Pity, Fear, and Citizenship', 51-5 also shows the importance of pity and fear for ethical deliberation, as well as the significance of identification with the suffering hero in tragedy. 
fellow human beings. Ká $\theta \alpha \rho \sigma \iota s$ enlarges our field of vision by forcing us to encounter and to process imaginatively and discursively our feelings of fear and pity. Through the processing of these feelings in both affective and rationally discursive ways, the spectator's ethical disposition toward his fellow citizens is brought back into a proper balance. Such balancing includes a greater sense of pity and care for one's fellow citizens.

As argued above in the chapter on the Gorgias, medicine and philosophy alike shared a strong ethical commitment to the wellbeing of soul and body. Contemporary models of medicine that see $\kappa \alpha ́ \theta \alpha \rho \sigma \varsigma$ as 'merely' purgation of feeling distract from the ancient concept of medical as linked to the ethical, in its seeking of restoration of health to the soul as well as body. ${ }^{40}$ Health on the ancient Hippocratic model is not the absence of a negative presence to the soul, but rather its restoration to a proper and proportional state of health. Purgation did not exist as a treatment that merely removed what was negative from the body, but rather, as a treatment that in removing the negative, thereby restored a positive balance natural to the body and its component humours.

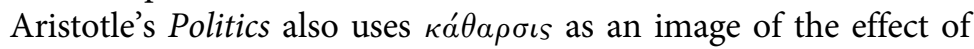
experiencing pity and fear in the context of music, in which the aim here, too, is the development of a more balanced state of soul:

[F]or some persons are very liable to this form of emotion, and under the influence of sacred music we see these people, when they use tunes that violently arouse the soul, being thrown into a state as if they had received medicinal treatment and taken a purge; the same experience then must come also to the compassionate and the timid and the other emotional people generally in such degree as befalls each individual of these classes, and all must undergo a purgation ( $\kappa a ́ \theta a \rho \sigma \iota s)$ and a pleasant feeling of relief; and similarly also the purgative melodies afford harmless delight to people. (Politics 1342a)

This passage has led some commentators to believe that the sole purpose of $\kappa a ́ \theta \alpha \rho \sigma \iota s$ is the relief from strong feelings, because of Aristotle's reference to pleasure and relief in conjunction with

\footnotetext{
${ }^{40}$ Jacob Bernays is usually credited as being among the first of contemporary commentators to identify кá $\theta \alpha \rho \sigma \iota s$ with medical purgation, in his Grundzüge der verlorenen Abhandlung des Aristoteles uver Wirkung der Tragödie. His work on $\kappa a \theta \alpha$ $\rho \sigma \iota s$ is available in Andrew Laird (ed.), Ancient Literary Criticism (Oxford: Oxford University Press, 2006).
} 
кá $\theta \alpha \rho \sigma \iota s$. However, as Golden argues, here Aristotle is not making a more general claim about $\kappa a ́ \theta \alpha \rho \sigma \iota$, but rather uses the imagery of a purge, of medical $\kappa a ́ \theta \alpha \rho \sigma \iota s$, in the larger context of comparing different types of musical melodies and their effects on shaping the soul. ${ }^{41}$ Some melodies, he says, are cathartic, while others are educative. Some calm, some delight, and others throw people into a terrible frenzy. The larger point of this passage is to argue that, given the tremendous power of music on the human soul, the right kind of music must be used for the right educative purpose, keeping in mind the temperament and character (as well as age) of those who listen to music. Aristotle offers his remarks about $\kappa a ́ \theta \alpha \rho \sigma \iota s$ here as part of a theory about musical education. ${ }^{42}$ In making our interpretation of his meaning here, this larger theoretical aim of education must be kept in mind. Aristotle's understanding of music in this context is for the soul who listens to it to become virtuous. This aim is achieved through balancing a soul that is out of balance, compensating for its deficiencies through giving it whatever reshaping or reformulation it needs. In this context, neither purification nor purgation completely captures the larger sense of reshaping as the goal of musical education. Rather, the $\kappa \dot{\alpha} \theta \alpha \rho \sigma \iota s$ of certain elements is one tool that allows one to achieve such a balancing.

Halliwell helpfully relates Aristotle's comment in the Politics about the shaping of the soul's $\epsilon^{\prime} \theta$ os by music to mean that music literally

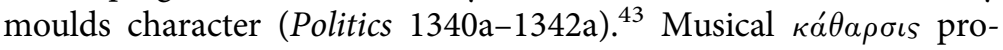
duces a kind of alleviation of pain and increase of pleasure, but not simply through a mechanistic release valve of some kind. Instead, $\kappa a ́ \theta \alpha \rho \sigma \iota$ effects a change in the soul through affecting its very ${ }_{\epsilon}^{\prime} \theta$ os, its disposition or character. Purgation, or the removal of a difficult element, is only one metaphor found in Aristotle's general examination of the proper use of music. An increase in spiritedness at times of war for the timid or calming of excessive enthusiasm might be more appropriate for other souls. The educative theories of Damon and similar ideas found in Book III of Plato's Republic support the prevalence of such a view of $\mu о v \sigma \iota \kappa \eta$ in classical Athens (Republic

\footnotetext{
${ }^{41}$ Leon Golden, Aristotle on Tragic and Comic Mimesis (Atlanta: Scholars Press, 1992), 8-12.

42 Golden, Aristotle on Tragic and Comic Mimesis, 8-12.

${ }^{43}$ Stephen Halliwell, 'Learning from Suffering: Ancient Responses to Tragedy', in Gregory (ed.), Companion to Greek Tragedy, 404-5.
} 


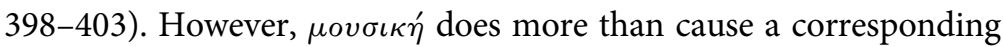
$\ddot{\epsilon}^{\prime} \theta o s$ in the soul. In fact, careful attention to the extended passage in the Politics also reveals a strong connection between imitation and

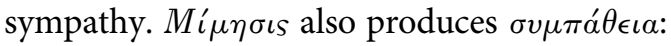

And moreover everybody when listening to imitations ( $\left.\mu \iota \mu \eta^{\prime} \sigma \epsilon o \nu\right)$ is thrown into a corresponding state of feeling $(\sigma v \mu \pi \alpha \theta \epsilon \hat{\imath} s)$, even apart from the rhythms and tunes themselves. And since it is the case that music is one of the things that give pleasure, and that virtue has to do with feeling delight and love and hatred rightly, there is obviously nothing that it is more needful to learn and become habituated to than to judge correctly and to delight in virtuous characters and noble actions. (Politics 8.1340a)

By $\sigma v \mu \pi \alpha ́ \theta \epsilon \iota a$ here, Aristotle does not seem to have in mind specifically compassion for the suffering, but rather experiencing feelings that correspond strongly to whatever is being imitated. Nonetheless, the passage is a rich one for deepening our understanding of sympathy in audience experience of tragedy, for it states that sympathy is one natural outcome of being affected by imitations, whether these imitations are strictly musical or not.

Aristotle's careful specification is that it is not only melody and rhythm, but the whole of the $\mu i \mu \eta \sigma \iota s$ taken in that causes the sympathetic effect. That is, Aristotle avoids a reductive explanation of the causal links between music and sympathy. Music does not simply shape the soul the way that sound waves affect the eardrum, i.e. mechanistically. Instead, imitation itself affects the soul because 'pieces of music contain in themselves imitations of character' (Politics 1340a). Music imitates life, and in turn the living are sympathetically affected by the music they hear; they become more like what they hear, which is itself (in some undefined way) already like the characters of people.

A similar point might be made even more strongly about $\mu i \mu \eta \sigma \iota s$ of character: tragic figures who overly imitate various types of human beings produce a sympathetic response in those who listen to and watch them; this is possible only because there is a fit between the mimetic reality and the reality being imitated (our earlier point about 'likeness' above). Indeed, the interlinking of music, dance, and rhythm in ancient tragedy would only heighten the effect of such mimetic power. $K \dot{\alpha} \theta \alpha \rho \sigma \iota s$, then, shapes the soul not through providing a release valve, but instead through a kind of rebalancing of the 
soul so that the tragic viewer leaves the theatre with his soul having been reshaped through $\mu i \mu \eta \sigma \iota s$.

Golden connects the Eleatic Stranger's use of $\kappa \alpha \dot{\theta} \theta \alpha \rho \sigma s$ in relation to the art of making distinctions in Plato's Sophist (230d-231a). There, the Stranger compares the removal of ignorance through cross-examination to the purification or $\kappa \alpha \dot{\alpha} \theta \alpha \rho \iota \varsigma$ of the soul. ${ }^{44}$ Golden argues that insofar as the goal of $\mu$ í $\mu \eta \iota s$ is intellectual pleasure (Poetics 1448b), the $\kappa \alpha \theta \alpha \rho \sigma \iota s$ achieved through $\mu \iota^{\prime} \mu \eta \sigma \iota s$ is a kind of intellectual clarification. However, Golden limits the effects of $\kappa \alpha \theta \alpha \rho \sigma \iota s$ to the intellect since the $\mu$ ' $\mu \eta \sigma \iota s$ that causes it is 'the word, spoken or read'. ${ }^{45}$ As I have argued, however, the audience experience of tragedy is primarily through being spectators at a performance, and so the cathartic effect of imitation is not solely verbal. Instead, the mimetic effect arises from the actions, words, musical expression, iconic masks, scenery, and other dimensions of performance that resonate with expressions, thoughts, ideas, actions, and surroundings of the ordinary world. Indeed, the whole of the tragic performance imitates the non-verbal along with the verbal-for example, using colour, sound, and gesture-to reveal something about the being of the world outside of the theatre. The verbal and logical is central to our experience of tragedy, to be sure, but so too is the sensory and non-verbal, in the theatre's drawing upon the imagination's occupation of a space between the purely intellectual and sensorial dimensions of experience. ${ }^{46}$ Mi $\mu \eta \sigma \iota s$ cathartically reshapes and purifies the soul through its making use of the imagination's largesse, so to speak. Theatrical performances mimetically embody multiple layers of human experience, in their attention to multiple dimensions of soul. $K \alpha \dot{\alpha} \theta \alpha \rho \sigma \iota s$, then, is the reshaping of the soul through its mimesis effecting sympathetic responses in its audience. In this sense, the theatrical world imitates the real world, but also the

44 Golden, Mimesis, 22-3.

45 Golden, Mimesis, 26.

46 Golden agrees with Nussbaum and Salkever that the affective as much as the rational is part of audience experience of tragic reality, but argues that the audience's grappling with the justice or injustice of suffering takes place at a purely rational level, as one 'weighs the evidence' (p. 33). However, as I have argued here, the point is that rationality itself is strongly informed by affective experience; the movement from imagination to practical reason does not leave behind the sensory, but rather the experiential and affective inform how practical reasoning takes place. For more on the relation between cognition and emotion, see W. W. Fortenbraugh, Aristotle on Emotion (New York: Duckworth, 1975), 12-22. 
'real' social world of the audience, and in its sympathetic responsiveness to the mimetic, is itself transformed and enlarged through its encounter with the dramatic.

$K \alpha \theta_{\alpha \rho \sigma \iota s}$, in this enlarged sense, as the soul's rebalancing, might be extended to being understood as the experience of the $\pi$ ó $\lambda_{\iota s}{ }^{47}$ While Aristotle himself focuses on the $\kappa a ́ \theta \alpha \rho \sigma \iota s$ of individuals, we might reasonably extend his analysis from the rebalancing of an individual to the rebalancing of the larger community. Given the overtly political nature of the Dionysian festival and the conversations that surely must have ensued after the performances had ended, the community itself might also undergo a kind of rebalancing and readjustment in its response to witnessing a performed tragedy. Timocles' fourth-century comedy Women Celebrating the Dionysia is revealing of the consolation and education that tragedy can provide. As Halliwell demonstrates, Timocles' speaker notes two elements to audience experiences of tragedy: a $\psi v \chi a \gamma \omega \gamma \gamma^{\prime} \alpha$ or soul-leading that is pleasurable while in the theatre; and the person who is now 'educated' ( $\left.\pi \alpha \iota \delta \epsilon^{\prime} v \theta \epsilon \iota S\right)$ as he leaves the theatre. Timocles identifies the benefit of tragedy as learning that one's own sorrows are bearable, in the light of even greater suffering. ${ }^{48}$ More narrowly, such 'education' could simply mean understanding that one's own daily sufferings are less significant than the possible scale of human suffering, through contrast of oneself to the tragic hero. However, Timocles' sense of education might also involve the $\psi v \chi \alpha \gamma \omega \gamma i \alpha$ of leading an audience member to place in perspective her own suffering in comparison to others in real, immediate community, through application of the play's insight to her own political situation. When Timocles speaks of the audience's engagement in the 'suffering ( $\pi \dot{\alpha} \theta \epsilon \iota)$ of others' (6), the immediate 'other' may be the tragic hero, but in later consideration the 'other' may grow to include the real sufferings of those in one's own city, or even other cities. The $\psi v \chi \alpha \gamma \omega \gamma$ ía of tragedy restores balance through restoring proper perspective on one's own suffering vis-à-vis the reality of others' lives. Such restoration of perspective on one's own life not only leads to greater contentment

\footnotetext{
47 One of the few commentators to look at the political place of tragedy in Aristotle's psychology is Bowie, 'Pity, Fear, and Citizenship'. Bowie focuses on the role of practical wisdom and deliberation, whereas my own attention here is on imagination and sympathy.

48 Halliwell, 'Learning from Suffering', 394-6.
} 
for oneself, but also potentially greater concern for others. This, too, is a form of $\kappa a ́ \theta \alpha \rho \sigma \iota s$, as an audience member is led away from the excesses of his self-absorption in his own narrower experiences of suffering or sorrow to be more engaged in those of others.

Finally, I want to suggest that tragedy can lead souls through enlarging a community's vision of its own reality. Here, I am stepping beyond Aristotle himself, but in a way that I hope is in keeping with the spirit of Aristotle's approach to tragedy. Tragedy asks members of the community-especially its most powerful members-to encounter the reality of suffering that they might otherwise avoid, despite its presence in the community. For example, Oedipus at Colonus envisions the possibility that the 'polluted one' might be understood not simply as the source of a city's illness, but rather as its protection. A Philoctetes who was excluded on the grounds of good piety emerges as central to the community's success. Analogues may also be found in the contemporary city. To avoid the truth of one's own community, the suffering in its midst, and the causes of such suffering is not merely to avoid controversial political opinions. To avoid truths about 'what is', including 'what is' in one's $\pi$ ó $\iota_{\iota s}$, is also to avoid one's own humanity. While Aristotle himself seems not to have extended his analysis of tragedy this far, such a view is not distant from an Aristotelian conception of ethics and epistemology. For Aristotle, not to see what the world seeks to reveal to us is to avoid an ethical responsibility we have both as knowers and as social beings for whom political relationships are forms of $\phi \imath \lambda_{i} \alpha$. Avoiding the reality of suffering is both a violation of the moral order and the epistemological order. In Aristotle's well-known words, 'All human beings by nature desire to know' (Metaphysics 980a), and to know is a key part of how we express and embody that nature. Not all of what needs to be known and understood, however, is pleasant. Indeed, an Aristotelian conception of $\epsilon \dot{\delta} \delta a \mu \nu_{i}{ }^{\prime} a$, happiness, requires a proper responsiveness to what is 'unhappy' at the moment. The courageous man does not avoid fearful or dangerous situations, but rather responds to them properly, in the right manner at the right time. Friendship requires vulnerability to one's closest friends, even at the risk of great loss. A virtuous man grieves appropriately for those he has lost, rather than not grieving at all.

The community, too, has an obligation to understand the truth of its own vulnerabilities, suffering, even flaws. Any self-understanding of a community that can see only its strengths is unbalanced. 
Consider some of the well-known adulatory remarks Pericles delivered in his funeral oration, as reported by Thucydides:

We cultivate refinement without extravagance and knowledge without effeminacy; wealth we employ more for use than for show, and place the real disgrace of poverty not in owning to the fact but in declining the struggle against it. Our public men have, besides politics, their private affairs to attend to, and our ordinary citizens, though occupied with the pursuits of industry, are still fair judges of public matters; for, unlike any other nation, regarding him who takes no part in these duties not as unambitious but as useless, we Athenians are able to judge at all events if we cannot originate, and, instead of looking on discussion as a stumbling-block in the way of action, we think it an indispensable preliminary to any wise action at all. Again, in our enterprises we present the singular spectacle of daring and deliberation, each carried to its highest point, and both united in the same persons; although usually decision is the fruit of ignorance, hesitation of reflection. But the palm of courage will surely be adjudged most justly to those, who best know the difference between hardship and pleasure and yet are never tempted to shrink from danger. ${ }^{49}$

Pericles' speech at the time provided an important balance to the losses of war. As their leader, he reminds them that grief and hardship are not the whole of the city. To see only loss in the community is to take an unbalanced view of its own reality. Pericles seeks to reveal the things themselves to the Athenians, that is, to remind them of the realities that they may not currently be able to access, through $\lambda$ 'ó that can again reveal what is good in the community to those who suffer.

But to take such comments as the final word on Athens would also be a misunderstanding of the truth of the $\pi o^{\prime} \iota s$. Tragedy provides a counterbalance to the community that praises itself too highly, or believes in the totality of its own virtue to the exclusion of suffering, conflicting obligations, marginalization, powerlessness, and like themes of tragedy. In a sense, then, tragedy can 'purge' a city of its excesses, through serving as a reminder of what is. Such purgation or rebalancing should not be understood to be 'merely' psychological, for the psychological and logical, the mental and the ontological, are closely linked for Aristotle. Tragedy, if engaged with responsively, can restore epistemological honesty to the community while

49 Thucydides, The History of the Peloponnesian War (London: Penguin, 1972), translated by Warner, Book 2, 34-46. 
simultaneously expanding its self-understanding to include greater wholeness, greater inclusion of what is already in its midst. Tragedy and philosophy, too, achieve this through a kind of transcendence of one's current circumstance, not as an escape, but rather so that we might return again to community ever more engaged with the truth of our own community, better prepared to be responsive to it. 
This is an open access version of the publication distributed under the terms of the Creative Commons AttributionNonCommercial-NoDerivs licence (http://creativecommons.org/licenses/by-nc-nd/3.0/), which permits non-commercial reproduction and distribution of the work, in any medium, provided the original work is not altered or transformed in any way, and that the work is properly cited. For commercial re-use, please contact academic.permissions@oup.com 


\section{8 \\ Conclusion}

In this work, I have argued that human vulnerability is central to a proper self-understanding of human individuals and the communities in which they live. Vulnerability-understood not only as the capacity to be wounded, but also as self-awareness and acceptance of being subject to harm-is not reducible to weakness or the absence of virtue. Instead, the right appropriation of vulnerability proves to be central to genuine self-knowledge and to the exercise of political virtue. The works of philosophy, epic, and tragedy in the previous chapters offer a variety of perspectives, both on the nature of vulnerability and the best ways in which to be responsive to its presence in communities. Achilles and Alcibiades, for example, have distinct struggles with different forms of moral weakness. However, in each case a certain acceptance or even embrace of vulnerability becomes crucial to virtuous living. Characters within these literary and philosophical works struggle with the right appropriation of their vulnerable condition, and their capacity to do so well or badly is deeply affected by the responses of their friends, families, comrades in arms, or partners in dialogue. The audience's encounter with such struggles with vulnerability in performed tragedy, epic, or philosophy invites the political community to witness and so more fully to incorporate the vulnerable into the body politic.

This book begins and ends with two works, the Iliad and the Poetics, which place the construction of narrative accounts at the centre of the appropriation of vulnerability. The Iliad links vulnerability to wounds and death to the very possibility of a teleological narrative of human existence, that is, to the development of a meaningful life story. In part, such meaning is made possible because the suffering of warriors is not solely an individual experience. Homer's descriptions of the many men who are wounded or die on the 
battlefield serve not only as an expression of the genuine loss inherent in human mortality, but also as the well-spring of the possibility of meaningful existence through narrative accounts that integrate the 'end' of life into a larger whole. Narrative ties together the experience of difficult events, such as impending death or the loss of a friend, with noble actions, or to instances of growth in understanding one's own humanity. Agamemnon's self-understanding is informed by Menelaos' wound; he suffers along with his brother, and brings his brother's suffering to bear upon his own attitude about the war and the meaning of its gains and losses. Achilles' ability to live and to die well arises from his successful integration of the death of his beloved friend, Patroklos. Paradoxically, that ability to assimilate loss takes place through his shared meal with Priam, his enemy's father, and his deepening of sympathy for Priam's loss. Not only pity for the suffering but, even more intimately, a shared sense of mortality makes possible the deepening of human friendship and political commitments. Indeed, the renewal of such commitments to the living, in the light of loss, helps to provide for the forward motion of life in a world subject to flux and to decay.

Oedipus at Colonus provides its audience with a vision of the incorporation and integration of the suffering and 'polluted' man into the body politic. While in the Oedipus Rex Oedipus' identity is that of a polluted man who must be excluded from the city, since he is the cause of its sickness, in Colonus he serves as the $\xi \epsilon^{\prime} v o s$ who protects the city's wholeness and integrity. Sophocles uses the plot device of $\pi \epsilon \rho \iota \pi \epsilon \tau \epsilon \iota$, or sudden reversal, to explore both vulnerability and its incorporation into the body politic. Oedipus becomes the welcomed stranger whose presence in Athens promises to provide the city with blessing instead of a curse. While moral blindness and ignorance are key vulnerabilities in human living, their reversal and resolution demand more than simply 'seeing' or knowing the truth. For Oedipus, only to know that he is the 'polluted one' is insufficient to solve the political problem he presents; even his exile does not solve the ensuing familial and political conflict that results for Thebes. Instead, a model of knowledge based on the faculty of touch-a mutual knowing and being known-and not vision as a one-way mastery of a distant object, guides Oedipus at Colonus. Moreover, Theseus' own ability to identify as a '̇́ยvos and to welcome Oedipus with hospitality as a result of his own appropriation of woundedness and exclusion allows for Athens' protection. In the play's action, this 
takes place with Oedipus' burial at the city's edge, but that literary incorporation of his body also signifies Athens' incorporation of vulnerability, the stranger, and even its accommodation of moral blindness and weakness. Through the figure of Theseus as the founder of democracy, the play expresses the centrality of the incorporation of the vulnerable and morally blind for Athens' retention of a democratic political identity that includes a wide sense of the $\delta \epsilon^{\prime} \mu o s$. Democracies, by their very nature in the inclusion of many people of varied characters and talents, must grapple with the inclusion of those at the margins in a way that oligarchies or aristocracies need not. Oedipus at Colonus suggests that a city's willingness to so include strangers, outsiders, and even the morally impure constitutes part of its democratic strength.

The Philoctetes further extends this political argument insofar as the character of Philoctetes exemplifies a dual value found in human vulnerability. First, through existing at the marginal space between society and isolation, between rejection and rejoining the war, Philoctetes has access to understanding his own humanity and especially his need of others in a way that more comfortable characters in the play do not. Experiencing a lack of what he needs gives him deep insight into the nature of human desire in a way that Oedipus seems to lack; vulnerability thus has an epistemological and moral value. Second, Neoptolemus' encounter with Philoctetes develops the youth's political virtue, especially his growth in the value of compassion and the ability to accommodate unjust harm. Both Neoptolemus and Philoctetes in their own ways must learn to reconcile themselves to imperfection and injustice in the political community, not through rhetorical manipulation (as Odysseus prefers), but rather through genuinely communicative speech and the development of a form of sympathy that can incorporate political reality. Philoctetes' future possibilities for friendship after betrayal require an acceptance of injustice and the risk of further injustice, not through meek acceptance, but rather through the active development of reconciliation with political imperfection. The permanence of some degree of injustice in the community presents significant challenges for political communities, and requires both a realistic understanding of one's community's limits and the development of political and personal sympathy to bridge differences.

In Plato's Gorgias, we turn to the consideration of self-wounding, and Socrates' philosophical engagement of his interlocutor as a form of $\theta \epsilon \rho \alpha \pi \epsilon^{\prime} a$. Rather than reading philosophical questioning 
as identical to the development of an argument for a particular moral or intellectual stance, a more expansive understanding of Socratic questioning includes how it becomes a $\theta \epsilon \rho \alpha \pi \epsilon^{i} a$ for the soul. Selfknowledge requires a certain nakedness of the self to judgement. So does the ability to judge and to address the needs of another justly: in the myth of the judged man, those who judge are, like Socrates, aware of their own limits and may even themselves have had to live with their own past self-wounding choices. Myth itself serves as an effective species of argument for producing greater self-awareness, since it engages the entirety of the soul, not only intellect or the passions alone. Through posing multiple images in argument to Callicles, Socrates attempts to reframe and to recontextualize the sort of life that Callicles values into a greater, cosmic whole. That greater perspective includes a recognition of the limits of human life, both the limits of death and the limits of freedom for the man who lives an unjust and unrestrained life. We are vulnerable not only to the loss of status, wealth, or life itself, but also to our own moral weakness and ignorance of our own nature. Such ignorance has political consequences, as those who avoid such vulnerabilities, like Callicles, treat politics as a means only to appetitive fulfilment at the city's expense. But Socratic questioning serves as a kind of treatment of the soul, one that at times functions to uncovers the soul's wounds and weaknesses in order that the soul might be healed and restored to balance. In this way, care of the soul and awareness of limit can prevent or repair harm to the city as well.

In the Symposium, attentiveness to vulnerability is crucial for the possibility of eros, widely construed. Love's relationality and expansion from the relatively narrow love of one lover for a single beloved body or soul to the love of the larger community's laws and institutions, and the creativity engendered through a more expansive love, requires vulnerability. Eros, in its highest forms, is not only about a lover and his or her object of love, but always about a lover, a beloved, and the creative acts that result from the encounter between lover and beloved. The source of this creativity, however, is in incompleteness and need, and a striving to be responsive to that need. While Diotima presents an idealistic notion of how eros can become increasingly creative in its responsiveness to incompleteness and need, Alcibiades represents a figure unable to reconcile to the vulnerabilities of aging, shame, and especially interpersonal need. His inability to recognize and to embrace his own limit also makes him unaffected 
by Socrates' attempts at a therapeutic care for Alcibiades' soul. Instead, Alcibiades remains frustrated with his own limits, retreating into ever-greater attempts to assert political power, and so loses the capacity to deepen his own moral virtue, care for the city, and for genuine friendship.

Aristotle also suggests that vulnerability is needed for friendship, even with the possession of the moral virtues. While the possession of the moral virtues indicates a kind of development of positive capacities in a person, and so a degree of self-sufficiency, the virtues have political value precisely because communities are built upon need. The virtuous man is self-sufficient in a sense, but still needs other persons with whom to exercise the virtues and with whom to develop one's most significant moral and political capacities. However, even more deeply, Aristotle's account of the loss of a friend who has become morally bad shows that he understands the friend also to be valuable as a particular, irreplaceable individual. A friend is 'another self'. While memory and narrative can continue to make a lost friend available in new and mediated ways, Aristotle displays sensitivity to the tragic in his admission that such memory is no substitute for a relationship with the friend himself. Moreover, those who lack moral virtue can only become better through the participation of the wider community in its educative functions, but no single friend, family, or political entity can fully satisfy this function. Political life, then, requires a complex set of interrelating social spheres of influence, from family and friends to political institutions that imperfectly address the needs of the vulnerable.

Tragic theatre is one such political institution: through the witnessing of suffering, audiences can become more aware of their own vulnerability and limits and more responsive to vulnerability in

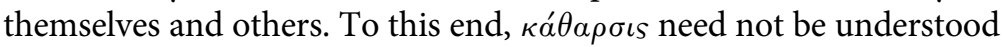
as the mere purification of pity and fear as an end in itself, but rather as a kind of 're-balancing' of the individual and also the community. Tragedy provides for a re-imagining of one's own social and political reality and the place of those normally at the margins within it. Aristotle's understanding of the imagination as a significant element in bringing thought to action suggests a powerful political role for performative art. Tragic theatre serves not only as entertainment, but also as a mode of mediating social and political relationships and reorienting the community's epistemological and affective attitudes 
to the vulnerable. Good political action depends on a certain understanding of human limit and vulnerability. Our own political communities would do well to respond in a similar fashion, not marginalizing the vulnerable, but instead recognizing a common bond between 'the vulnerable' and oneself.

This is an open access version of the publication distributed under the terms of the Creative Commons AttributionNonCommercial-NoDerivs licence (http://creativecommons.org/licenses/by-nc-nd/3.0/), which permits non-commercial reproduction and distribution of the work, in any medium, provided the original work is not altered or transformed in any way, and that the work is properly cited. For commercial re-use, please contact academic.permissions@oup.com 


\section{Bibliography}

Ahrensdorf, Peter. 2009. Greek Tragedy and Political Philosophy: Rationalism and Religion in Sophocles' Theban Plays. Cambridge: Cambridge University Press.

Annas, Julia. 1977. 'Plato and Aristotle on Friendship and Altruism', Mind 86: 532-54.

1993. The Morality of Happiness. Oxford: Oxford University Press.

Arieti, James. 1993. 'Plato's Philosophical Antiope: The Gorgias in Plato's Dialogues'. In Gerald Press (ed.), Plato's Dialogues: New Studies and Interpretations. New York: Rowman and Littlefield, 197-214.

Aristotle. 1894. Nicomachean Ethics, ed. J. Bywater. Oxford: Clarendon Press. Accessed online at the Perseus Digital Library $<\mathrm{http}: / / \mathrm{www}$. perseus.tufts.edu/ hopper/text?doc=Perseus\%3atext\%3a1999.01.0053>, 2010-12.

— 1895. Poetics, trans. S. H. Bucher. London: MacMillan. Accessed online at the MIT Internet Classics Archive. <http://www.classics.mit.edu/Aristotle/ poetics.html>, 2010-11.

- 1941. De Anima, trans. J. A. Smith. In Aristotle, The Basic Works of Aristotle, ed. Richard McKeon. New York: Random House.

1984. The Rhetoric and the Poetics of Aristotle, introd. Edward Corbett. New York: McGraw-Hill.

1985. Nicomachean Ethics, trans. Terence Irwin. Cambridge, Mass.: Hackett.

1987. Poetics I with the Tractatus Coislinianus, a Hypothetical Reconstruction of Poetics II, the Fragments of On Poets, Book I, translated with an introduction by Richard Janko. Cambridge, Mass.: Hackett.

- 2001. On Memory and Reminiscence, trans. Rhys Roberts and Ingram Bywater. In The Basic Works of Aristotle, ed. Richard McKeon. New York: Random House.

Aulus Gelius. 1927. The Attic Nights of Aulus Gelius, Books 1-5, trans. J. C. Rolfe. Cambridge, Mass.: Loeb.

Avery, Harry C. 1965. 'Heracles, Philoctetes, Neoptolemus', Hermes 93 (3): 279-97.

Ballengee, Jennifer R. 2009. The Wound and the Witness: The Rhetoric of Torture. New York: SUNY Press.

Barker, Derek. 6 November 2003. 'Pity, Fear, and Citizenship: The Politics of Aristotle's Poetics', Paper Presented at the Annual Meeting of the North Eastern Political Science Association, Crowne Plaza Hotel, Philadelphia, PA Online $<$.PDF $>$. accessed online at $<$ http://www.allacademic.com/meta/ p89675_index.html>, 26 May 2009. 
Bartos, Hynek. 2006. 'Varieties of the Ancient Greek Body-Soul Distinction', Rhizai 3 (1): 59-78.

Beer, Josh. 2004. Sophocles and the Tragedy of Athenian Democracy. Westport, Conn.: Praeger.

Belfiore, Elizabeth. 1993-4. 'Xenia in Sophocles' Philoctetes', Classical Journal 89 (2): 113-29.

- 2002. 'Review of David Konstan, Pity Transformed', Bryn Mawr Classical Review, 14 April 2002, accessed online at <http://bmcr.brynmawr.edu/ 2002/2002-04-14.html>, 21 August 2010.

Bespaloff, Rachel. 2005. War and the Iliad. New York: New York Review of Books.

Biancalana, Joseph. 2005. 'The Politics and Law of Philoctetes', Law and Literature 17 (2): 155-82.

Blundell, Mary Whitlock. 1989. Helping Friends and Harming Enemies: A Study in Sophocles and Greek Ethics. Cambridge: Cambridge University Press.

— 1988. 'The Phusis of Neoptolemus in Sophocles' "Philoctetes"', Greece and Rome, Second Series 35 (2): 137-48.

Bostock, David. 1998. 'Pleasure and Activity in Aristotle's Ethics', Phronesis 33 (3): 251-72.

Bowery, Anne Marie. 2007. 'Know Thyself: Socrates as Storyteller', in Gary Scott (ed.), Philosophy in Dialogue Form: Plato's Many Devices. Evanston, Ill.: Northwestern University Press, 82-109.

— 2007. 'Socratic Reason and Emotion: Revisiting the Intellectualist Socrates in Plato's Protagoras'. In Ann Ward (ed.), Socrates: Reason or Unreason as the Foundation of European Identity. Cambridge: Cambridge University Press, 2007, 1-29.

- 2009. 'The Narrative Frame of Plato's Euthydemus', Southwest Philosophy Review 24: 163-72.

Bowie, A. M. 1997. 'Tragic Filters for History: Euripides' Supplices and Sophocles' Philoctetes'. In B. R. Pelling (ed.), Greek Tragedy and the Historian. Oxford: Oxford University Press, 39-62.

-2008. 'Pity, Fear, and Citizenship: The Politics of Aristotle's Poetics'. In Derek Barker (ed.), Tragedy and Citizenship: Conflict, Reconciliation, and Democracy from Haemon to Hegel. New York: SUNY Press, 41-62.

Brann, Eva. 1992. The World of the Imagination: Sum and Substance. Lanham, Md.: Rowman and Littlefield.

Brill, Sara. 2005. 'Diagnosis and the Divided Line: Pharmacological Concerns in Plato's Republic', Epoché 9 (2): 297-315.

- 2006. 'Medical Moderation in Plato's Symposium', Studies in the History of Ethics, Symposium on Bioethics, accessed online at $<$ www.historyofethics.org $>$. Budelmann, Felix. 2000. The Language of Sophocles: Communality, Communication, and Involvement. Cambridge: Cambridge University Press. 
Burkert, W. 1955. 'Zum altgriechischen Mitleidsbegriff'. Erlangen: Inaugural-Dissertation, Friedrich-Alexander-Universität.

Burnet, John, ed. 1989. Platonis Opera, Vols. I-IV. Oxford: Oxford University Press.

Cairns, Douglas. 1993. Aidos: The Psychology and Ethics of Honor and Shame in Ancient Greek Literature. Oxford: Oxford University Press.

Carson, Anne. 1998. Eros the Bittersweet. Champaign, Ill.: Dalkey.

Cartledge, Paul. 1997. 'Deep Plays: Theatre as Process in Athenian Civic Life'. In P. E. Easterling (ed.), The Cambridge Companion to Greek Tragedy. Cambridge: Cambridge University Press, 3-35.

Clarke, Michael. 2004. 'Manhood and Heroism'. In R. Fowler (ed.), The Cambridge Companion to Homer. Cambridge: Cambridge University Press, 74-80.

Clay, Jenny Strauss. 2011. Homer's Trojan Theater: Space, Vision, and Memory in the Iliad. Cambridge: Cambridge University Press.

Coolidge, Francis P., Jr. 1993. 'The Relation of Phlosophy to Sophrosune: Zalmoxian Medicine in Plato's Charmides', Ancient Philosophy 13 (1): 23-36.

Cooper, John. 1977. 'Friendship and the Good in Aristotle', Philosophical Review 86: 290-315.

- 1999. Reason and Emotion. Princeton: Princeton University Press.

Corrigan, Kevin, and Elena Glasov-Corrigan. 2004. Plato's Dialectic at Play: Argument, Structure, and Myth in the Symposium. University Park, Pa.: Pennsylvania State University Press.

Croally, Neal. 2005. 'Tragedy's Teaching'. In J. Gregory (ed.), A Companion to Greek Tragedy. Oxford: Blackwell, 60-1.

Crotty, Kevin. 1994. The Poetics of Supplication: Homer's Iliad and Odyssey. Ithaca, NY: Cornell University Press.

Csapo, E., and W. Slater. 1995. The Context of Ancient Drama. Ann Arbor: University of Michigan Press.

Debnar, Paula. 2005. 'Fifth Century Athenian History and Tragedy'. In J. Gregory (ed.), A Companion to Greek Tragedy. Oxford: Blackwell.

Diodorus Siculus. 1935. Library of History, Vol. II, Books 2.35-4.58 (Loeb), trans. C. H. Oldfather. Cambridge, MA: Harvard University Press.

Drake, Ryan. 2007. 'Natural and Divine Orders: The Politics of Sophocles' Philoctetes', Polis 24 (2): 179-92.

Drum, Peter. 2003. 'What is the Motivation of Morality for Friendship in Aristotle?', Journal of Value Inquiry 37: 97-9.

Ebbott, Mary. 2005. 'Marginal Figures'. In J. Gregory (ed.), A Companion to Greek Tragedy. Oxford: Blackwell, 352-376.

Edelstein, Ludwig. 1945. 'The Role of Eryximachus in Plato's Symposium', Transactions and Proceedings of the American Philological Association 76: 85-103.

Farenga, Vincent. 2006. Citizen and Self in Ancient Greece. Cambridge: Cambridge University Press. 
Foley, H. P. 1981. Reflections of Women in Antiquity. New York: Gordon and Breach.

1981. 'The Conception of Women in Athenian Drama'. In H. P. Foley (ed.), Reflections of Women in Antiquity. New York: Gordon and Breach, 127-68.

Fortenbraugh, William. 1975. Aristotle on Emotion. New York: Duckworth.

Fowler, Robert, ed. 2004. The Cambridge Companion to Homer. Cambridge: Cambridge University Press.

Frede, Michael. 1987. Essays in Ancient Greek Philosophy. Minneapolis: University of Minnesota Press.

Fussi, Alessandra. 2001. 'The Myth of the Last Judgment in the Gorgias', Review of Metaphysics 5 (3): 529-52.

2009. 'Love of the Good, Love of the Whole: Diotima's Response to Aristophanes in Plato's Symposium', Epoche 13 (2): 267-90.

Gheaus, Anca. 2009. 'The Challenge of Care to Idealizing Theories of Distributive Justice'. In Lisa Tessman (ed.), Feminist Ethics and Social and Political Philosophy: Theorizing the Non-Ideal. Berlin: Springer, 105-19.

Gill, Christopher. 1980. 'Bow, Oracle, and Epiphany in Sophocles' Philoctetes', Greece and Rome 27 (2): 137-46.

Gill, David. 2008. 'The Great Poem: Why the Iliad Matters', Boston College Magazine, Spring 2008, accessed online at $<\mathrm{http} / / / \mathrm{bcm} . b c . e d u /$ issues/ winter_2008/features/the-great-poem.html>, 15 September 2010.

Gill, Mary Louise, and Pierre Pellegrin, eds. 2006. A Companion to Ancient Philosophy. Oxford: Blackwell.

Goff, Barbara. 1995. History, Tragedy, Theory: Dialogues on Athenian Drama. Austin, Tex.: University of Texas Press.

Golden, Leon. 1992. Aristotle on Tragic and Comic Mimesis. Atlanta: Scholars Press.

2005. Understanding the Iliad. Bloomington, Ind.: Authorhouse.

Goldhill, Simon, and Edith Hall, eds. 2009. Sophocles and the Greek Tragic Tradition. Cambridge: Cambridge University Press.

Gordon, Jill. 2012. Plato's Erotic World. Cambridge: Cambridge University Press.

Gregory, Justina, ed. 2005. A Companion to Greek Tragedy. Oxford: Blackwell. Grene, David, trans. and ed. 1991. Sophocles I: Oedipus the King, Oedipus at Colonus, Antigone, 2nd edn. Chicago: University of Chicago Press.

Gribble, D. 1999. Alcibiades and Athens: A Study in Literary Presentation. Oxford: Oxford University Press.

Griffin, Jasper. 1980. Homer on Life and Death. Oxford: Oxford University Press.

— ed. 1995. Iliad: Book Nine. Oxford: Oxford University Press.

Griswold, Charles. 2002. 'Irony in the Platonic Dialogues', Philosophy and Literature 26 (1): 84-106. 
2003. 'Longing for the Best: Plato on Reconciliation with Imperfection', Arion 11: 101-36.

Gurtler, Gary, SJ. 2003. 'The Activity of Happiness in Aristotle's Ethics', Review of Metaphysics 56: 801-34.

Hackforth, R. 1950. 'Immortality in Plato's Symposium', Classical Review 64 (2): 43-5.

Haden, J. C. 1992. 'Two Types of Power in Plato's "Gorgias"', Classical Journal 87: 313-26.

Hadreas, Peter. 2004. 'The Functions of Pleasure in Nicomachean Ethics x 4-5', Ancient Philosophy 24: 155-67.

Hainsworth, Brian, ed. 1993. The Iliad, A Commentary. Cambridge: Cambridge University Press.

Hall, Edith. 2005. Greek Tragedy and the British Theatre: 1660-1914. Oxford: Oxford University Press.

Halliwell, Stephen. 2005. 'Learning from Suffering: Ancient Responses to Tragedy'. In J. Gregory (ed.), A Companion to Greek Tragedy. Oxford: Blackwell, 394-412.

Hammer, Dean. 2002. 'The Iliad as Ethical Thinking: Politics, Pity, and the Operation of Esteem', Arethusa 35 (2): 203-35.

— 2002. The Iliad as Politics: The Performance of Political Thought. Norman, Okla.: University of Oklahoma Press.

— and Michael Kicey. 2010. 'Simone Weil's Iliad: The Power of Words', Review of Politics 72: 79-96.

Hammond, Paul. 2009. The Strangeness of Tragedy. Oxford: Oxford University Press.

Hawkins, Anne. 1999. 'Ethical Tragedy and Sophocles' Philoctetes', Classical World 92: 337-57.

Hemmenway, Scott. 1990. 'Philosophical Apology in the Theaetetus', Interpretation 17: 323-46.

Henderson, Jeffrey. 1991. 'Women and the Athenian Dramatic Festivals', Transactions of the American Philological Association 121: 133-47.

— 2000. 'Aspects of the Ancient Greek Symposium', Akroterion 45: 6-25. Hippocrates, 2007. 'On Injuries of the Head', trans. Francis Adams. ebooks@ Adelaide $<\mathrm{http} / / /$ bbooks.adelaide.edu.au/h/hippocrates/head $>$.

Holmes, Brooke. 2007. 'The Iliad's Economy of Pain', Transactions of the American Philological Association 137 (1), accessed online at the Muse database <http://muse.jhu.edu.proxy.bc.edu/journals/transactions_of_the_ american_philological_association/toc/apa137.1.html> 13 July 2011.

Homer. 1997. The Iliad, trans. Stanley Lombardo. Cambridge, Mass.: Hackett Press.

Howland, Jacob. 2007. 'Plato's Dionysian Music: A Reading of the Symposium', Epoche 12 (1): 17-47. 
Inoue, Eva. 1979. 'Sight, Sound, and Rhetoric: Philoctetes 29ff.', American Journal of Philology 100 (2): 217-27.

Ionescu, Cristina. 2007. 'The Transition from the Lower to the Higher Mysteries of Love in Plato's Symposium', Dialogue 46 (1): 27-42.

Jacquette, Dale. 2001. 'Aristotle on the Value of Friendship as a Moral Motivation', Journal of Value Inquiry 35: 371-89.

Jameson, M. H. 1956. 'Politics and the Philoctetes', Classical Philology 51 (4): $137-48$.

Kieffer, John S. 1942. 'Philoctetes and Arete', Classical Philology 37 (1): 38-50.

Kim, Jinyo. 2000. The Pity of Achilles: Oral Style and the Unity of the Iliad. Lanham, Md.: Rowman and Littlefield.

Kirkwood, Gordon. 1994. 'Persuasion and Allusion in Sophocles' "Philoctetes"', Hermes 122 (4): 425-36.

Klosko, George. 1983. 'The Insufficiency of Reason in Plato's Gorgias', Western Political Quarterly 36: 579-95.

— 1984. 'The Refutation of Callicles in Plato's Gorgias', Greece and Rome 31: 126-39.

Knox, Bernard. 1957. Oedipus at Thebes: Sophocles' Tragic Hero and his Time. New Haven: Yale University Press.

Konstan, David. 2006. The Emotions of the Ancient Greeks: Studies in Aristotle and Greek Literature. Toronto: University of Toronto Press.

Kosman, L. A. 1976. 'Platonic Love'. In W. H. Werkmeister (ed.), Facets of Plato's Philosophy. Assen: Van Gorcum, 53-69.

Kristeva, Julia. 1991. Strangers to Ourselves, trans. Leon S. Roudiez. New York: Columbia University Press.

Lada-Richards, Ismene. 2005. 'Greek Tragedy and Western Perceptions of Acting'. In J. Gregory (ed.), A Companion to Greek Tragedy. Oxford: Blackwell, 459-71.

Laird, Andrew, ed. 2006. Ancient Literary Criticism. Oxford: Oxford University Press.

Long, Christopher. November 2009. 'A Father's Touch, a Daughter's Voice: Antigone, Oedipus and Ismene at Colonus', presented at the 2010 Sophocles Colloquium, University of Utah.

— 2010. Aristotle on the Nature of Truth. Cambridge: Cambridge University Press.

Lynn-George, K. 1996. 'Structures of Care in the Iliad', Classical Quarterly 46 (1): $1-26$.

Lynn-George, Michael. 1993. 'Aspects of the Epic Vocabulary of Vulnerability', Colby Quarterly 29 (3): 197-221.

McCoy, Marina Berzins. 2005. 'Philosophy, Elenchus, and Charmides's Definitions of Sophrosune', Arethusa 38: 133-59. 
2007. Plato on the Rhetoric of Sophists and Philosophers. Cambridge: Cambridge University Press.

McDonald, Marianne, and J. Michael Walton, eds. 2007. The Cambridge Companion to Greek and Roman Theatre. Cambridge: Cambridge University Press.

MacIntyre, Alasdair. 2001. Dependent Rational Animals: Why Human Beings Need the Virtues. Chicago: Open Court.

Manoussakis, John Panteleimon. 2009. 'Thebes Revisited: Theodicy and the Temporality of Evil', Research in Phenomenology 39 (2): 292-306.

Markantonatos, Andreas. 2007. Oedipus at Colonus: Sophocles, Athens, and the World. Berlin: De Gruyter.

Martin, Richard. 2009. 'Ancient Theater and Performance Culture'. In Maryanne McDonald and Michael Walton (eds.), The Cambridge Companion to Greek and Roman Theater. Cambridge: Cambridge University Press.

Mills, Sophie. 1997. Theseus, Tragedy, and the Athenian Empire. Oxford: Oxford University Press.

Morgan, Kathryn A. 2000. Myth and Philosophy from the Presocratics to Plato. Cambridge: Cambridge University Press.

Nagy, Gregory. 1979. The Best of the Achaeans: Concepts of the Hero in Archaic Greek Poetry. Baltimore: Johns Hopkins University Press.

Naiden, F. S. 2006. Ancient Supplication. Oxford: Oxford University Press.

Neal, Tamara. 2006. The Wounded Hero: Non-Fatal Injury in Homer's Iliad. Bern: Peter Lang.

Nehamas, Alexander. 2007. " "Only in the contemplation of beauty is human life worth living", Plato Symposium 211d', European Journal of Philosophy 15: $1-18$.

Nichols, Mary P. 2004. 'Socrates' Contest with the Poets in Plato's Symposium', Political Theory 32 (2): 186-206.

Nietzsche, Friedrich. 1967. The Birth of Tragedy, trans. Walter Kaufman. New York: Vintage.

Nightingale, Andrea. 2000. Genres in Dialogue: Plato and the Construct of Philosophy. Cambridge: Cambridge University Press.

— 2004. Spectacles of Truth in Classical Greek Philosophy. Cambridge: Cambridge University Press.

Nussbaum, Martha. 1976. 'Consequences and Character in Sophocles' "Philoctetes", Philosophy and Literature 1 (1): 25-53.

— 1979. 'The Speech of Alcibiades: A Reading of Plato's Symposium', Philosophy and Literature 3 (2): 131-72.

— 1986. The Fragility of Goodness. Rev. edn. Cambridge: Cambridge University Press.

1994. The Therapy of Desire: Theory and Practice in Hellenistic Ethics. Princeton: Princeton University Press. 
Nygren, Anders. 1953. Agape and Eros, trans. Philip S. Watson. Philadelphia: Westminster.

Oele, Marjolein. 2010. 'Suffering, Pity, and Friendship: An Aristotelian Reading of Book 24 of Homer's Iliad', Electronic Antiquity 14 (1): 52-65. Osborne, Robin. 2004. 'Homer's Society', in R. Fowler (ed.), The Cambridge Companion to Homer. Cambridge: Cambridge University Press, 206-19.

Palmer, L. R. 1963. The Interpretation of Mycenean Greek Texts. Oxford: Oxford University Press.

Pangle, Lorraine Smith. 2003. Aristotle and the Philosophy of Friendship. Cambridge: Cambridge University Press.

Parker, Robert. 2003. Miasma: Pollution and Purification in Early Greek Religion. Oxford: Oxford University Press.

Pascal, Blaise. 1995. Pensées, trans. A. J. Krailsheimer. London: Penguin.

Payne, Andrew. 2008. 'The Teleology of the Ascent in Plato's Symposium', Apeiron 41: 123-46.

Pedrick, Victoria, and Steven M. Oberhelman. 2005. The Soul of Tragedy: Essays on Athenian Drama. Chicago: University of Chicago Press.

Pellegrin, Pierre. 2006. 'Ancient Medicine and its Contribution to the Philosophical Tradition'. In Mary Louise Gill and Pierre Pellegrin (eds.), A Companion to Ancient Philosophy. Oxford: Blackwell, 664-85.

Pelling, B. R. 1997. Greek Tragedy and the Historian. Oxford: Oxford University Press.

Pickard-Cambridge, A. W. 1988. The Dramatic Festivals of Athens, 2nd edn. Oxford: Oxford University Press.

Plato. 1986. Gorgias, trans. Donald Zeyl. Cambridge, Mass.: Hackett.

— 1991. Republic, 2nd edn. trans. and with a commentary by Allan Bloom. New York: Basic Books.

- 1991. Symposium, trans. R. E. Allen. New Haven: Yale University Press. 1995. Platonis opera, ed. E. A. Duke. Oxford: Clarendon.

n.d. Timaeus, trans. Benjamin Jowett. Mineola, NY: Dover.

Plutarch. n.d. Lives, Vol. I, trans. John Dryden with revisions by A. H. Clough. New York: A. L. Burt.

Pratt, Louise. 2007. 'The Parental Ethos of the Iliad', Hesperia Supplements 41: 25-40.

Pratt, Norman T. 1949. 'Sophoclean "Orthodoxy" in the Philoctetes', American Journal of Philology 70 (3): 273-89.

Press, Gerald, ed. 1993. Plato's Dialogues: New Studies and Interpretations. Lanham, Md.: Rowman and Littlefield.

Prior, William J. 2006. 'The Portrait of Socrates in Plato's Symposium'. In Oxford Studies in Ancient Philosophy, Vol. XXXI. Oxford: Oxford University Press, 137-66.

Purves, Alex. 2010. Space and Time in Ancient Greek Narrative. Cambridge: Cambridge University Press. 
Rangos, Spyridon. 2005. 'On Diotima's Allusions to Earlier Speakers in Plato's Symposium', Skepsis 16 (1): 164-78.

Redfield, James. 1994. Nature and Culture in the Iliad: The Tragedy of Hector. Durham, NC: Duke University Press.

Roisman, M. 2005. Sophocles: Philoctetes. Duckworth Companions to Greek and Roman Tragedy. London: Duckworth.

Roochnik, David. 1991. The Tragedy of Reason: Toward a Platonic Conception of Logos. London: Routledge.

— 2003. Beautiful City: The Dialectical Character of Plato's Republic. Ithaca, NY: Cornell University Press.

Rorty, Amelie Oksenberg. 1992. Essays on Aristotle's Poetics. Princeton: Princeton University Press.

Rose, Peter. 1976. 'Sophocles' Philoctetes and the Teachings of the Sophists', Harvard Studies in Classical Philology 80: 49-105.

Rousseau, Jean-Jacques. 1992. Discourse on the Origin of Inequality, trans. Donald Cress. Cambridge, Mass.: Hackett.

Salkever, Stephen, ed. 2010. The Cambridge Companion to Ancient Greek Political Thought. Cambridge: Cambridge University Press.

Santas, Gerasimos. 1979. 'Plato's Theory of Eros in the Symposium', Nous 13: 67-75.

Saxonhouse, Arlene. 1988. 'Thumos, Justice, and Moderation of Anger in the Story of Achilles'. In Catherine Zuckert (ed.), Understanding the Political Spirit. New Haven: Yale University Press.

— 2006. Free Speech and Democracy in Ancient Athens. Cambridge: Cambridge University Press.

Schein, Seth. 1984. The Mortal Hero: An Introduction to Homer's Iliad. Berkeley and Los Angeles: University of California Press.

Schindler, D. C. 2007. 'Plato on the Problem of Love: On the Nature of Eros in the Symposium', Apeiron 40 (3): 199-220.

Scodel, Ruth. 2005. 'Sophoclean Tragedy'. In J. Gregory (ed.), A Companion to Greek Tragedy. Oxford: Blackwell, 233-49.

Scott, Gary 2002. Does Socrates Have a Method? University Park, Pa.: Pennsylvania State University Press.

— ed. 2007. Philosophy in Dialogue Form: Plato's Many Devices. Evanston, Ill.: Northwestern University Press.

and William Welton. 1996. 'An Overlooked Motive in Alcibiades' Symposium Speech', Interpretation 24 (1): 67-84.

Segal, Charles. 1977. 'Philoctetes and the Imperishable Piety', Hermes 105 (2): 133-58.

— 1999. Tragedy and Civilization: An Interpretation of Sophocles. Norman, Okla.: University of Oklahoma Press.

Seidensticker, B. 1995. 'Women on the Tragic Stage'. In B. Goff (ed.), History, Tragedy, Theory: Dialogues on Athenian Drama. Austin, Tex.: University of Texas Press, 151-73. 
Smith, P. Christopher. 2002. 'Nietzsche and Gadamer: From Strife to Understanding, Achilles/Agamemnon to Achilles/Priam', Continental Philosophy Review 35: 379-96.

Sophocles. 1898. The Philoctetes of Sophocles, edited with an introduction and notes by Richard Jebb. Cambridge: Cambridge University Press. Perseus Digital Library, $<$ http://www.perseus.tufts.edu/hopper/text?doc=Perseus\%3atext\%3a1999.01.0193> accessed 2010-12.

Sourvinou-Inwood, Christiane. 1989. 'Assumptions and the Creation of Meaning: Reading Sophocles' Antigone', Journal of Hellenic Studies 109: 134-48.

2005. 'Tragedy and Anthropology'. In J. Gregory (ed.), A Companion to Greek Tragedy. Oxford: Blackwell, 293-304.

Stephens, J. Ceri. 1995. 'The Wound of Philoctetes', Mnemosyne 48 (2): 153-68.

Stern-Gillett, Suzanne. 1995. Aristotle's Philosophy of Friendship. New York: State University of New York Press.

Tarnopolsky, Christina H. 2010. Prudes, Perverts, and Tyrants: Plato's Gorgias and the Art of Shame. Cambridge: Cambridge University Press.

Tessitore, Aristide. 2003. 'Justice, Politics, and Piety in Sophocles' Philoctetes', Review of Politics 65 (1): 61-88.

Tessman, Lisa, ed. 2009. Feminist Ethics and Social and Political Philosophy: Theorizing the Non-Ideal. Berlin: Springer.

Thesaurus linguae Graecae. Irvine, Calif.: University of California, Irvine.

Thornton, Bruce. 1977. Eros: The Myth of Ancient Greek Sexuality. Boulder, Colo.: Westview.

Thucydides. 1972. The History of the Peloponnesian War. London: Penguin. Vickers, Michael. 2008. Sophocles and Alcibiades: Athenian Politics in Ancient Greek Literature. Ithaca, NY: Cornell University Press.

Vlastos, Gregory. 1981. Platonic Studies, 2nd edn. Princeton: Princeton University Press.

- 1981. 'The Individual as an Object of Love in Plato'. In Platonic Studies, 2nd edn. Princeton: Princeton University Press, 3-42.

Walker, Henry J. 1995. Theseus and Athens. Oxford: Oxford University Press.

Walker, Margaret. 2006. Moral Repair. Cambridge: Cambridge University Press.

Weil, Simone, and Rachel Bespaloff. 2005. War and the Iliad. New York: New York Review Books.

Werkmeister, W. H., ed. 1976. Facets of Plato's Philosophy. Assen: Van Gorcum.

Wilcock, Malcolm M. 1976. A Companion to the Iliad. Chicago: University of Chicago Press.

Wilson, Joseph. 1997. The Hero and the City: An Interpretation of Sophocles' Oedipus at Colonus. Ann Arbor: University of Michigan Press. 
Winkler, John J. 1991. 'Laying Down the Law: The Oversight of Men's Sexual Behavior in Classical Athens'. In Froma Zeitlin, John J. Winkler, and David Halperin (eds.), Before Sexuality. Princeton: Princeton University Press, 171-201.

Wordsworth, William. 1800. Preface to the Second Edition of Lyrical Ballads. Repr. London: Longman.

Zanker, Graham. 1996. The Heart of Achilles: Characterization and Personal Ethics in the Iliad. Ann Arbor: University of Michigan Press.

Zeitlin, Froma. 1996. Playing the Other: Gender and Society in Classical Greek Literature. Chicago: University of Chicago Press.

John J. Winkler, and David Halperin, eds. 1991. Before Sexuality. Princeton: Princeton University Press.

Zielinski, Thaddaeus. 1901. Die Behandlung gleichzeitiger Ereignisse, im antiken Epos. Leipzig: Dieterich.

Zuckert, Catherine, ed. 1988. Understanding the Political Spirit. New Haven: Yale University Press. 
This is an open access version of the publication distributed under the terms of the Creative Commons AttributionNonCommercial-NoDerivs licence (http://creativecommons.org/licenses/by-nc-nd/3.0/), which permits non-commercial reproduction and distribution of the work, in any medium, provided the original work is not altered or transformed in any way, and that the work is properly cited. For commercial re-use, please contact academic.permissions@oup.com 


\section{Index}

Achilles x, xv, 1, 1 n., 2, 6, 7 n., 13, 15, 16-30, 19 n., 21 n., 26 n., 27 n., 30-35, 30 n., 31 n., 32 n., 33 n., 34 n., 70-1, 82-4, 102, 122, 169, 205-6

armour of $17,24-5,70-1$

shield of 13,35

Aeschylus 48, 54, 73

Eumenides 54, 172

Agamemnon 2, 6-9, 7 n., 15, 16, 18, 19-20, 22, 25, 26-7, 26 n., 59

Agathon 130

Aineias 5

Alcibiades xii, 95, 97, 106, 108, 110, 113, 117, 131-9, 133 n., 134 n., 138 n., 169, 182, 182 n., 185, 190, 205

aletheia see truth

ally $15,40,69,70$

Andromache 3, 30

Anger 19, 20-2, 21 n., 24-5, 41, 52 n., $53,57,70,79-80,83,98,136,180$, 184; see also rage

Antigone 48, 49-50, 52-3, 54, 58, 181, 184 n., 185,190

Aphrodite 4-7, 9-11

Apollo 5, 15, 17, 31, 77

appetite 95, 99-100, 188, 190, 208

Ares 4, 9-11, 10 n., 30

Aristophanes 128-30, 130 n., 138

Aristotle x, xii-xiii, 10, 21-2, 45, 51, 72, 95, 141-67, 143 n., 147 n., 169-71, 173-7, 180-1, 186-98, 200, 200 n., 202, 209

De Anima 169, 186, 188, 190

Magna Moralia 142, 151

Metaphysics 201

Nicomachean Ethics 51, 95, 141, 144-54, 157-65, 170-1, 194

On Memory and Reminiscence 154-5

Poetics xii-xiii, 45, 169, 173-6, 180, 186, 189-90, 193, 195, 199, 205

Politics 160, 162, 166, 195-8

Rhetoric 21, 72, 151, 169, 173-4, 193-4

Athena $5,10,28,30,60$
Athens xi, 48-9, 54, 55, 56, 58-62, $61 \mathrm{n}$., 62 n., 83 n., 108, 131, 132, 133, 135, $175,181,182,183,184,190,197$, 202, 206-7

battle $1,3,4,5,10,11,15,16,19-20,23$, $24,25-7,28,40,87,101,145,174$

beauty $4,12,13,34,92,115-16,117-125$, 116 n., $130-1,132-3,136$

betrayal $8,22,77-82,86,131,157,207$

blindness $37-8,42,45,48,54,178,183$ moral $206-7$

blood 5-6, 22, 28

body xiii, 11, 27, 60, 62, 62 n., 100, $108-9,110-11,117,120,127,187$, 190, 195, 196, 207, 208

of Hektor x, 15, 16, 30-4, $34 \mathrm{n}$.

bow, Philoctetes' 63-4, 67, 69-70, 73-5, $76-80,82,84,85$ n., 86, 185

Briseis 24, 29, 83

brothers 3, 5-9, 48, 52, 111, $184 \mathrm{n}$., 190, 206

burial; see funeral

Callicles xi, 91-2, 96-104, 99 n., 103 n., $110-12,137,169,185,208$

catharsis; see katharsis

chance $\mathrm{x}, 46,82,145-6,161,164$

character viii, $2,9,11-13,17,18$ n., 32 n., 37, 63, 72-4, 79, 95, 97, 101, 127, $142,145,146,147,149-50,152$, $153,154,157,159-60,159$ n., 160 n., $163-5,171,173-4,177-81,185$, 190, 192, 193, 197-8, 207

Colonus 61; see also Sophocles

communication vii, xi, $6,7,8,11-13,21$, $23,63,65,67-8,85,102,151,154$, $156,172,175,207$

community viii-xi, $1-4,11,13,16-18$, 21-2, 24-6, 37-9, 43, 54-6, 60, 62, 64-5, 68-9, 71, 75, 77, 79-83, 85, $87,104-5,135,139,143,146,159$, $161,163,166-7,169-70,172,176$, 179-80, 182, 183, 184, 185, 191, $192,195,200-3,205,207-10$

This is an open access version of the publication distributed under the terms of the Creative Commons AttributionNonCommercial-NoDerivs licence (http://creativecommons.org/licenses/by-nc-nd/3.0/), which permits non-commercial reproduction and distribution of the work, in any medium, provided the original work is not altered or transformed in any way, and that the work is properly cited. For commercial re-use, please contact academic.permissions@oup.com 
compassion xi, 37, 40, 47-50, 53-5, 61, $62,64,75,79$ n.81, 107, 119, 175 n., 196, 198, 207; see also sympathy

contact $43,50,66-8$

contingency $\mathrm{x}, 13,83,142-3,143 \mathrm{n}$., $154-5,163,167,180$

corpse $14-15,24,30,43,99$

courage $1,5,6,34,55,57,57$ n., 95, 145, $148,164,171,184,194,201,202$

creativity xii, 116-17, 119, 121, 125-6, 129-30, 137, 139, 139 n., 189, 208

Creon $38-9,42,47-8,50-2,55,181$, 183,190

criminal 40-2, 159

crossroads 54

curse $38,39,48,52-3,57,59,78-9,85$, 180,206

\section{Damon 197}

daughters $16,39,49-50,52-3,59$

death $\mathrm{x}, 1-4,10-11,17-19,23-5,27-30$, $32-3,35,43-4,49,52-3,58,62,70$, 79-80, 86, 91-7, 99, 102-5, 113, $122-4,128,131,134,136-8,142$, 151, 151 n., 170-1, 176, 184, 205-6, 208

deception $22,41,52,67,70,74,78$, 81,101

demos 60, 207

dependence ix, $\mathrm{x}, \mathrm{xii}, 3,5,20-1,31,37$, 49, 50, 108, 129, 129 n., 143, 144, $146,158,160,165,171,173-4,175$, $183,187,188,191-2,210$

desire $\mathrm{x}$, xii, 7 n., 8, 21, 26, 32 n., 41, 45-6, 52, 52 n., 60, 63, 66, 67, 70, 71, $77-8,83,85,86,91,95,99,107-8$, $115,120,122,124,124$ n., 126-7, 130, 132-6, 134 n., 144, 148, 150, $167,174,178,181-2,188,189$, 201, 207

despair 39,79

Diomedes 4, 10, 16, 144

Diotima xii, 115-24, 126-7, 130, 131, 134, 136-7, 139, 139 n., 189, 208 dishonour 17, 19, 21

eating $5,27-8,30-31,33-35,123,161$, 188; see also meal

eleos; see pity

emotion xi, 14, 21, 22, 34, 34 n., 45, 64, 72, 74-5, 74 n., 81, 89, 98, 99, 107,
$165,173,175,178,183,186,190$, 193-6, $199 \mathrm{n}$.

end, final; see teleology

endurance $6,9,11,12,13,15,25,46,49$, $50,53,66,79,147$

eros; see love

Eryximachus 127-8

Eteocles 51-3

eudaimonia 46, 143, 167, 171

Euripides 60 n., 73, 132

Cyclops 132

Suppliants 60 n., 174, 182

Trojan Women 179

Eurypylus $24-5$

excellence, moral; see virtue

exile $38,41,43,49-50,52-6,58,61-2$, $81,174,206$

family xi, xiii, xvi, 3,7 n., $8,10,20,48$, $59,61,65,72,73,92,143,160-3$, $165,167,170,181,190,194,205$, 206, 209

fate $13,38,39,46,48,54,60,61,78$; see also fathers; sons; daughters; brothers; marriage

fathers $3,6,8,12,20-1,25,29,32-3,33$ n., 38,41 n., $42-3,47-8,50-4,57$, 59-60, 70, 78, 83-4, 132, 136, 178, $181,183,206$

fear $6-8,42,43,46,54,72,82,99,102$, $105,107,134,138,144,161,170$, 173-5, 185, 186, 192-6, 195 n., 201, 209

forms, Platonic 89, 115-16, $116 \mathrm{n}$., $117-21,122,123,126,131$

freedom 39, 43, 48, 52-3, 73 n., 75, $80,95,100,103,138,162,164$, 184, 190, 208

friendship xiii, 7, 17, 22, 29, 33 n., 66, 67, $68,69,73,76-7,78$ n., 79, 80, 81, 84, 85, 128, 141-63, 145 n., 147 n., 159 n., 166-7, 169, 193, 194, 201, 206, 207, 209

as mirror of self $145,150-1$

memory of $150,153-6$

funeral $15,27,30,35,184,202$

\section{gaze $2,34,122-3$}

gentleness 24, 42, 48, 50, 54, 61, 113

gift, exchange of in guest-host relationship 56-7, $78 \mathrm{n}$. 
glory viii, 1,7 n., $8,11-12,15,17-19,22$, 26-7, 31, 32 n., 65, 71, 76, 76 n., 79, $85-6,122$

gods, Greek x, 3-6, 9-11, 17, 22, 28, 29-30, 31, 32, 34, 34 n., 39, 40, $43,47,50,56,59,63,69,71,74$, 77, 79, 83-6, 92, 121, 127, 130, $131,152,181$

Gorgias 96, 98, 99, 103, 111

grief 2, 7, 7 n., 9, 15, 19, 19 n., 27-8, 30, $32-4,33$ n., 35, 72, 76, 152, 156, 183, 201, 202

healing xii, $10-11,22-5,65,82,84$, $85-6,108,110,111,129,136,208$; see also medicine

Hektor x, 1, 3, 13, 15, 16, 18, 22, 28-30, $30-5$

Hephaistos 4, 13, 30

Hera 9-10, 22, 30

Herakles 63, 69-70, 74, 76-7, 76-7 n., $80,82,84-7,180$

hero viii, 1, 6, 11, 12, 17, 18, 18 n., 39, 40, 57, 58 n., 59, 59 n., 61, 95, 173, 177, 195 n., 200

Hippocrates 107, 109-10, 112

Homer viii, $x, 1,3-16,18-22,18$ n., 19 n., 28, 30-1, 31 n., 33-5, 33 n., 56, $71,92,112,144,169-70,205$

honour viii, 1 n., 2, 3, 7-8, 12, 17-20, 24, 26-8, 27 n., 32, 70, 77, 80-1, 96, $141,144,148,167,172,174$

hospitality xi, $31,34,39-42,48-53,55$, 61, 206

identity xi, xiii, $11,17,23-4,32,37,44$, $52-4,57-60,66,68,98,131,136$, $159,190,192,206-8$

ignorance $\mathrm{x}, 37-9,41,43,47-8,50-2$, $68,84,96-7,108,123,137,184,199$, 202, 206, 208

illness 44, 55, 81, 105-6, 108, 112, 161, $163,189,201,206$

imagination $\mathrm{x}, 6,22,33 \mathrm{n} ., 41-2,72,77$, $82,91,98-101,148,172-3,177-80$, 186-92, 196, 199 n., 200 n., 209; see also phantasia

imitation 33, 102, 118, 173, 176, 190, 198-9

immortality $4-6,9,13,23,28,32,121-4$, 126,134

impermanence $12-13$ incest $42-3,47,51-2,54,56,178,183$

incontinence $159,161-5$

injury $\mathrm{x}, 4-12,23,81,108-9$

injustice $40-2,96,100,102-3,131,137$, 169, 194, 199, 207

interdependency $86,150,156,158$, 161,167

Jocasta $39,42,46-8,46 \mathrm{n}$.

justice $1,19,24,40-1,57$ n., 68, 75-77, $80,83,85,94,97,102,105,108,137$, $142,163,169,173,181-2,193-4$, $199 \mathrm{n}$.

katharsis xiii, 170, 192-203, 209

kinaidos 91, 99-100

kingship 40-1, 49, 185

knowledge 23-5, 39, 41, 45, 47, 49-51, 57, 62 n., 106, 122, 124, 133, 137, $142,154,156,161,162,178,183$, $185,195,202$

as modeled on sight $37-8,46,49$, 53-4

as modeled on touch $49-51,206$ as recognition 47 see also self-knowledge

Laius 39, 41-2, 44, 59

language xi, 44-5, 46 n., 58, 66, 78-9, $85,92-3,107,118,121-2,125,138$, 171 n., 182, 191; see also logos

life, as defined through facing death 3 , $8-18,26-32,35,92-7,170,205-6$ light $26,38-9,44,69,74,80,93,116 \mathrm{n}$. liminality $6,27,40,185$

logos $26,44,53,66-8,83,91-2,101,103$, $122,135,138,191-2$

loss xii, $2,4-6,8,12-13,16-17,19-22$, $26,28-30,32-3,35,70,77,81,99$, $121,124,132,138,143,149-54$, $156-7,164,169,201-2,206,208-9$

love $12,18,19$ n., $32-3,33$ n., 40, 47, 59, 70, 107, 119-20, 142-3, 143 n., 146-53, 155-6, 159-62, 166, 185, 194, 198, 208

Agathon's account of 130

Aristophanes' account of 128-30

Diotima's account of xii, 115-16, 117-18, 121-4, 124 n., 126-7, 130, 130 n., 136-7, 189

Eryximachus' account of 127-8 and $\log o s$ 101, 103, 138-9 
love (cont.)

Pausanius' account of 127

Phaedrus' account of 126-7

of Socrates for Alcibiades 131-4, 136

of the good x, xiii, 115, 146-7, $147 \mathrm{n}$., $149,151,152,159$

luck ix, 142, 145-6, 161, 163-4

Lykaon 28-9

Machaon 7, 22-4

MacIntyre, Alasdair 189

magnanimity $33,162,171$

marginal figures xi, 64, 184-6, 192, 195, 202, 207, 209-10

marriage $9,12-13,46,50$

meal 2, 19, 28, 30-1, 33, 35, 153, 159, 206; see also eating

medicine xii, 23-5, 90, 105-11, 128, 170, 195-6

memory xiii, $14,20,28,53,62$ n., 150 , 153-6, 209

Menelaos 6-9, 7 n., 15-16, 59, 206

mercy 42

miasma; see pollution

mimesis; see imitation

moderation $42,57,84,99,106,143$, 160,171

mortality viii, $x, 1,3-9,11-19,22 \mathrm{n}$., 26-33, 46, 76, 96, 98, 104, 112, 117, 121, 123-4, 130 n., 131, 170, 175,206

mourning; see grief

mousike; see music

movement, temporal 10, 16-17, $18 \mathrm{n}$., $19,23-4,28-30$

music $23,128,157,195-9$

myth viii, xi, 55, 91-2, 97, 99 n., 100-1, 169, 208

of Aristophanes 128-9

of judgment in Gorgias xi-xii, 90-104, 112, 185, 208

see also narrative

mythos see myth

Nagy, Gregory 18 n., 19, 25 n., 31 n. naming $11,19,58,132$

narrative vii, ix-x, xiii, 1-2, 8-14, 16-18, 19 n., 23, 34 n., 39-40, 67 n., 70, 79 n., 85-6, 90, 92, 99 n., 118, 153-6, 169-71, 181-2, 192, 205-6, 209

nature $4,10,12-13,31$ n., 40, 43-5, 50, $63-4,67,73,75-6,92,94-5$,
98-100, 106, 108, 110, 112, 127-9, 141-3, 147-8, 154, 161-2, 164, 172, $176-7,189,191-2,196,201,208$

need vii, xii-xiii, 20, 25, 30-1, 38, 47-8, $50,52,58$ n., 64, 66-7, 70-2, 77, 84, $86,99,104,120-2,125-6,128-9$, $131,133-4,136-8,142-5,153$, 159-162, 164, 166-7, 174, 189, 197-8, 201-9

Neoptolemus xi, 64-84, 86-7, 101, 165, $178,185,207$

Niobe 33

nomos 99-100, 104, 117

Nussbaum, Martha 73 n., 76 n., 89, 107, 131, 138, 142, 145, 146 n., 156 n., 160 n., 163, 186, 199 n.

oath $7,9,74,183$; see also promise

Odysseus 27-8, 63-5, 67, 69-71, 73-6, $78-81,83,101,144,182,185,207$

Oedipus $\mathrm{x}-\mathrm{xi}, 37-62,169,174,177-9$, $181,183,185,201,206-7$

pain; see suffering parricide 21, 43, 50-1, 52 n., 178

Pascal 119-20, 218

pathos 26, 175, 178-80, 200; see also emotion

Patroklos x, 2, 15-17, 19, 21-30, $32-3,206$

Pausanias $127-8$

Peleus 20-1, 25, 32-3

Pelops 59

Pericles 84, 202

Phaedrus 126, 128

phantasia 186-9; see also imagination philia see friendship

Philoctetes xi, 63-5, 65-72, 73-5, 76-87, 79 n., 83 n., 84 n., 101, 105, 165, 169, 179-80, 182, 185, 192, 201, 207

phobos; see fear

Phoenix 20-1, 26 n.

phusis; see nature

piety 55 n., 57 n., 58 n., 75-6, 78, 81, 201

pity xi, 20-2, 26, 27 n., 32-3, 44, 47, 50, 53, 63-5, 68 n., 75-6, 78, 81, $164,170,173-5,178,186,192-6$, 206, 209

in contrast to sympathy $72-3$ Plato:

Apology 91, 96, 102-3, 113 n., 137,184 
Gorgias xi, 89-104, 112, 137, 169, 196, 207

Phaedo 91, 136-7

Phaedrus 94, 126-8, 139

Republic 89, 105, 107-8, 166, 197

Sophist 199

Symposium xi-xii, xvi, 94-5, 97, 110, 115-18, 122-39, 175, 185, 189, 208

Theaetetus 108, 112, 113 n., 125

Timaeus 108-9

Plutarch 21, 60-1

Poiesis 130, 180-1, 189-90

polis viii, $2,60-2,184,192,201-2$

pollution xi, 37, 40-4, 46-52, 54-6, $60-1,178,185,201,206$

Polus 96-8, 103, 103 n., 183

Polyneices $51-3,57$

Poseidon 30-1, 92

Priam x, xv, 2, 8, 20, 26 n., 29-35, 87, 164,206

promise $7,20,30,75,78,85,87,111$, 158,206

prophecy $37-8,41,46$ n., 49

questioning

as form of speech $66,71,137,139$, 179-81

Socratic x, xii, 100, 107 n., 108, 113, $137,184,207-8$

rage $18-20,24,27-8,30,34,41-2,83$; see also anger

reason 26 n., 52 n., 57, 65-6, 75, 77, 79, $89,91,102-3,111$

in relation to affect $98-9,176-80$, 186, 189-90, 194, 199 n.

reliance 157,174

reproduction, erotic xii, 116, 118-19, $121-2,124,127,129-30,136$

responsibility, moral xii, 39-42, 50-2, $55,112-13,136-8,159,164-5$

reversal $44-6,61,173-5,177,206$

sacrifice $8-9,27-8,65,69,85,122,127$, $184 \mathrm{n}$.

self-control 12

self-knowledge $37-8,47,93-7,103,111$, $117,142,185,195,205$

self-sufficiency x, 27, 142-3, 145 n., 158, 160,209

shame 5, 54, 74, 86, 98-9, 103 n., 117, $133-5,208$ shore $63-4$

sickness; see illness

Simoeis $12-14$

Skamander 17, 28-30

society xi, 3, 41, 54, 63-4, 66, 67 n., 69, $80,82,84,159-60,163,165,179$,

186,207 ; see also community

Socrates x-xii, 58 n., 89, 90-2, 92-7, 98-104, 105-8, 107 n., 110-13, $115-17,118,119,124-6,129-30$, $131-9,144,169,184-5,207-8,209$

song 23-4

sons $5,7,12,20,32-3,46$ n., 48, 50, 52-3, 59-60, 70, 77 n., 78, 81-2, 84, $86,136,183$

Sophocles:

Antigone 52, 183, 190

Oedipus at Colonus $\mathrm{x}-\mathrm{xi}, 37,39-40$, 42, 48-51, 53-4, 56-7, 56 n., 57 n., 60 n., 61, 201, 206-7

Oedipus Rex 37-9, 44, 48-9, 50-1, 52, 178, 179, 181, 206

Philoctetes xi, 22, 63-72, 73-89, 101, $105,178-9,180,182,207$

soul-leading 200-1

spirit $6,28,54$

story; see narrative

stranger; see xenos

suffering vii-xiii, 4, 6-12, 15, 18-22, 27

n., $33-5,39,48-50,53,61-2,64,68$, $70,72,74-5,77,80,82-3,85-6,95$, $103,105,110-11,129,132-3,157$, $167,169-71,174,175-9,181,183$, 190, 193-5, 198, 199 n., 200-2, 205-6

supplication $16,32,71-2,78,81$

symmetry $16-17$

sympathy $5,7,11,21,34,55$ n., 57, 68, 200 n., 206-7

and audience experience of tragedy $70,174-5,178-80$, 186, 198

contrasted to pity $72-3$

in Rousseau 176

sympatheia; see sympathy

Teiresias 37-8, 41-2, 45-6

teleology x, 1, 9-11, 16, 106, 115-16,

$165,170,205$

temperance; see moderation

temporality vii, $1 \mathrm{n} ., 2,17,19,23-4$, 33 n., 34, 124, 170

This is an open access version of the publication distributed under the terms of the Creative Commons AttributionNonCommercial-NoDerivs licence (http://creativecommons.org/licenses/by-nc-nd/3.0/), which permits non-commercial reproduction and distribution of the work, in any medium, provided the original work is not altered or transformed in any way, and that the work is properly cited. For commercial re-use, please contact academic.permissions@oup.com 
therapeia 108, 111-12, 208

Theseus xi, 37, 40, 42, 49, 53-62, 174,

$$
\text { 206-7 }
$$

Thetis 25, 28, 32

Timocles:

Women Celebrating the Dionysia 200

tragedy viii-xiii, 44, 70, 90, 169-87, 190-5, 198-203, 205, 209

trust, in contrast to reliance $157-8$

truth xi, 41, 44-6, 53, 67, 77, 82, 93-8, $101,112,133-4,136,138,144,178$, 190-2, 201-3, 206

tuche; see chance; see luck

vice $161,164-5,169$

virtue vii-xiii, $1-2,1 \mathrm{n} ., 12,15-17,42$, 55 n., 57, 63, 79, 90, 95-6, 111-12, $127-8,131,133,137,177,194,198$, 202, 205, 209

and friendship 141-3, 144-52, $145 \mathrm{n}$., 147 n., 153-7, 158-67, 194, 209

of Achilles 18-20, 31

of Neoptolemus 64, 67-8, 82-3, 207

voice $49,53,58,65,85,90,118,179,184$

voluntary action $51-2,81-2$

vulnerability, definition of vii war viii, 3, 5-10, 13-16, 23-7, 29-30, 61, $63,65,69,71,73,79,81,83-4,146$, $172,174,179-80,197,202,206-7$

Weil, Simone 1 n., 14, 19 n., 30 n.

wisdom $37-8,42,45,47-8,57,58$ n., 62 , $89,94,112,125,137,181$

practical wisdom $122-3,152,200 \mathrm{n}$.

wounds vii, xii, $1,37,42,49,53-4,63-4$, $68,70,73-4,77,79,81-2,84,87,90$, 92, 95-6, 100-1, 103 n., 104-5, 117, $164,169,176,205-8$

divine and mortal, contrasted 3-13, 15-16, 21-6

in Hippocratic medicine 108-9, 111-12

of Alcibiades 131-2, 135,

of Aristophanes' lovers 129, 136

xenos xi, 37, 39-40, 44-5, 49, 53-61, 65-6, 77, 206-7

Zeus 5, 9-11, 22, 29, 32-3, 56, 86, 92-3, 95, 129

and response to wounding of other gods $5,9-11$

Zeus Xenios 56-7

This is an open access version of the publication distributed under the terms of the Creative Commons AttributionNonCommercial-NoDerivs licence (http://creativecommons.org/licenses/by-nc-nd/3.0/), which permits non-commercial reproduction and distribution of the work, in any medium, provided the original work is not altered or transformed in any way, and that the work is properly cited. For commercial re-use, please contact academic.permissions@oup.com 